\title{
WestVirginiaUniversity
}

THE RESEARCH REPOSITORY @ WVU

Graduate Theses, Dissertations, and Problem Reports

2005

\section{Cellular mechanisms of luteal regression in the bovine corpus luteum $(\mathrm{CL})$}

Aritro Sen

West Virginia University

Follow this and additional works at: https://researchrepository.wvu.edu/etd

\section{Recommended Citation}

Sen, Aritro, "Cellular mechanisms of luteal regression in the bovine corpus luteum (CL)" (2005). Graduate Theses, Dissertations, and Problem Reports. 2266.

https://researchrepository.wvu.edu/etd/2266

This Dissertation is protected by copyright and/or related rights. It has been brought to you by the The Research Repository @ WVU with permission from the rights-holder(s). You are free to use this Dissertation in any way that is permitted by the copyright and related rights legislation that applies to your use. For other uses you must obtain permission from the rights-holder(s) directly, unless additional rights are indicated by a Creative Commons license in the record and/ or on the work itself. This Dissertation has been accepted for inclusion in WVU Graduate Theses, Dissertations, and Problem Reports collection by an authorized administrator of The Research Repository @ WVU.

For more information, please contact researchrepository@mail.wvu.edu. 


\title{
Cellular Mechanisms of Luteal Regression in the Bovine Corpus Luteum (CL)
}

\author{
Aritro Sen, M.S. \\ Dissertation submitted to the \\ Eberly College of Arts and Sciences \\ at West Virginia University \\ in partial fulfillment of the requirements \\ for the degree of \\ Doctor of Philosophy in \\ Biology \\ Jorge A Flores, Ph.D., Chair \\ E Keith Inskeep, Ph.D. \\ Matthew E. Wilson, Ph.D. \\ Christy Foran, Ph.D. \\ Keqiang Wu, Ph.D. \\ Department of Biology \\ Morgantown, West Virginia, U.S.A. \\ 2005
}

Keywords: corpus luteum, $\mathrm{PGF}_{2 \alpha}, \mathrm{ET}-1, \mathrm{PKC}$ isoforms, calcium, luteal regression 


\title{
Abstract \\ Cellular Mechanisms of Luteal Regression in the Bovine Corpus Luteum (CL)
}

\begin{abstract}
Aritro Sen
The corpus luteum (CL) is a transient endocrine gland that produces progesterone (P4) for the establishment and maintenance of pregnancy. In absence of pregnancy, timely regression of the CL is essential for normal ovarian cyclicity. Several factors are known to participate in luteal regression. In this study, two factors, PGF2 alpha and endothelin (ET-1) are being studied. Protein kinase $\mathrm{C}$ (PKC) and calcium are the two main intracellular mediators of PGF2 alpha. The role of ET-1 in the regulation of luteal regression is unclear. The early $\mathrm{CL}$ is insensitive to the luteolytic actions of PGF2 alpha and the cellular mechanism(s) involved in this process are poorly understood. This study investigates: (1) the array of PKC isozyme expression as a function of development in the bovine CL and the ability of PGF2 alpha and ET-1 to activate the PKC isozymes in the early (day-4) and late (day-10) luteal phase, (2) the physiological role of the luteal PKC isozymes on PGF2 alpha -induced rise in intracellular calcium concentration and luteinizing hormone (LH) stimulated P4 accumulation at the mid lueal phase and (3) the cellular source of the luteal PKC isozymes. PKC alpha, beta I, beta II, epsilon and meu were observed to be expressed in the bovine CL with beta II and epsilon being differentially expressed as a function of development. In day-10 CL PGF2 alpha and ET1 were able to activate PKC alpha, beta I and epsilon. More importantly, PKC epsilon was found to be involved in the regulation of PGF2 alpha induced rise in intracellular calcium concentration and antagonized the inhibitory effect of PGF2 alpha and ET-1 on LH-stimulated P4 accumulation in cultures of day-10 luteal steroidogenic cells (SC). PKC epsilon was found exclusively expressed in SC. In contrast, PKC alpha, beta I and beta II were expressed in both SC and endothelial cells (EC), with SC expressing higher amounts than EC. In this study we have proposed that the differential expression and activation of PKC epsilon as a function of development may be one of several factors responsible for the insensitivity of the early CL. Expression of PKC epsilon in the mid luteal phase shifts the PGF2 alpha induced rise in intracellular calcium concentration from a P4 favorable to a P4 inhibitory condition. Based on these observations it is hypothesized that the insensitivity of the early CL towards the luteolytic actions of PGF2 alpha may be due to differences in the intracellular mediators with respect to luteal development.
\end{abstract}




\section{Contents}

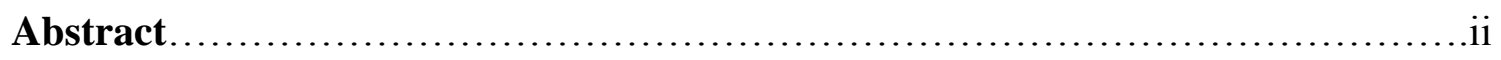

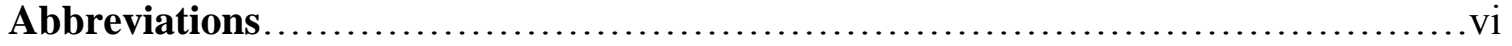

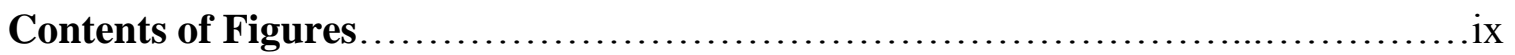

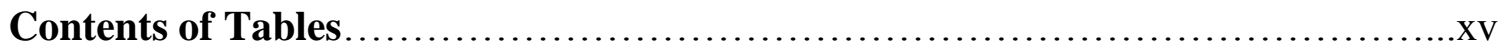

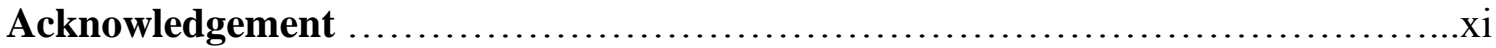

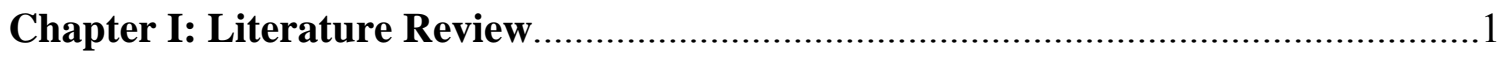

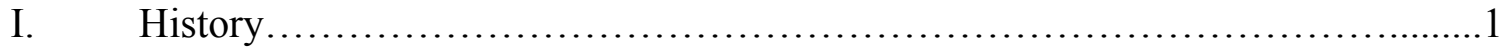

II. Development of the CL.....................................................

1. Cellular Composition, Cell morphology, Cell division and

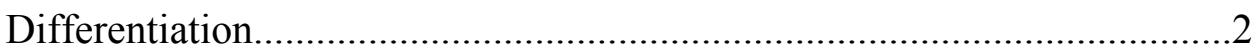

2. Angiogenesis...................................................... 4

III. Luteal Steroidogenic Pathway ............................................ 6

1. Cholesterol transport into and within cells............................

2. Cholesterol transport across mitochondrial membranes...................8

3. Regulation of P4 Synthesis by Luteotropic Factors.......................11

IV. Prostaglandin (PG) Metabolic Pathway..................................... 15

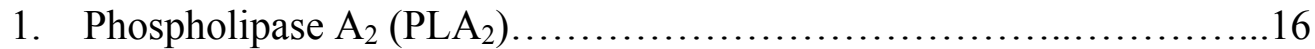

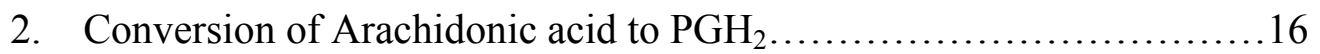

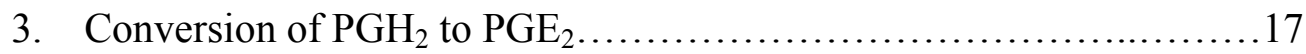

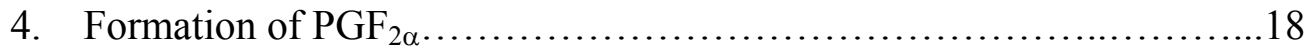

5. Catabolism of PGs.....................................................19

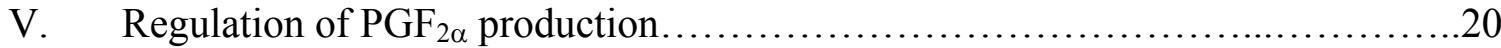

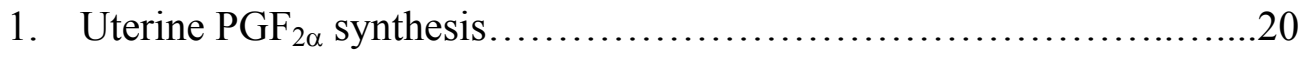

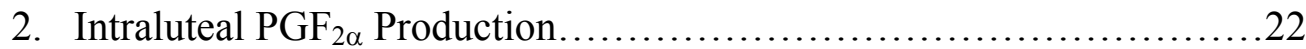

3. Prostaglandin Transport..............................................23

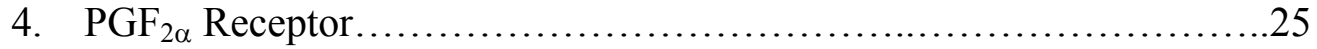

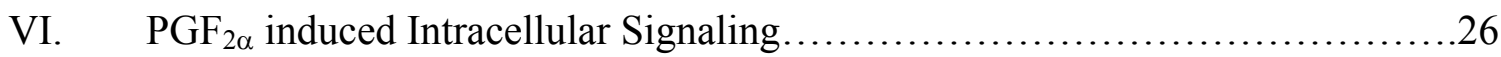




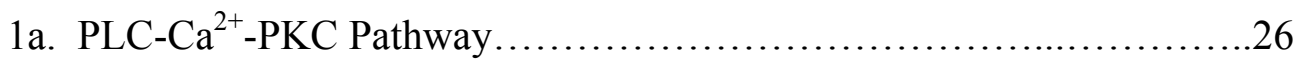

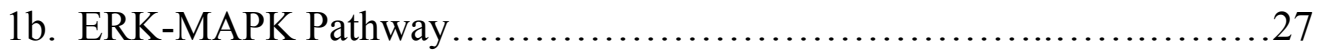

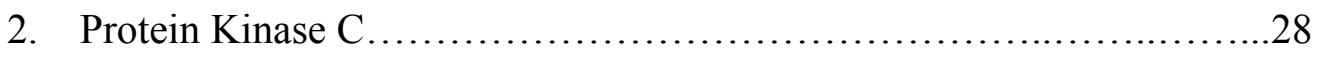

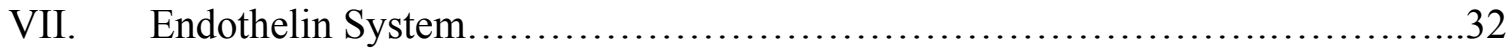

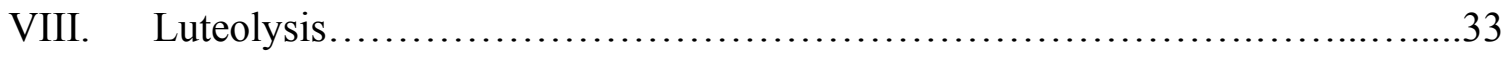

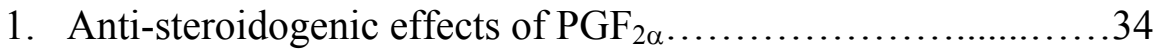

2. Regulation of Luteal Regression by the Endothelial (ET)

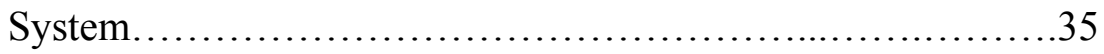

3. Other Factors................................................

Chapter II: Statement of Problem................................................ 40

Chapter III: Expression and Activation of Protein Kinase C Isozymes by Prostaglandin $\mathbf{F}_{2 \alpha}$ in the Early and Mid-Luteal Phase Bovine Corpus Luteum......43

1. Introduction................................................... 43

2. Materials and Methods........................................ 45

3. Results................................................... 47

4. Discussion.................................................. 50

Chapter IV: Effects of Selective Protein Kinase C Isozymes in Prostaglandin $\mathbf{F}_{2 \alpha}$ induced $\mathrm{Ca}^{2+}$ Signaling and Luteinizing Hormone-Induce Progesterone Accumulation in the Mid-Phase Bovine Corpus Luteum.........................58

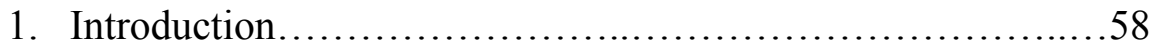

2. Materials and Methods.....................................60

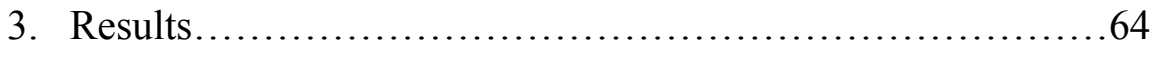

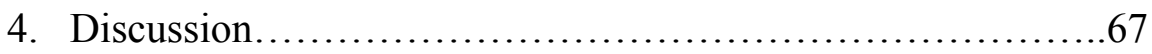

Chapter V: Cellular Source of Luteal PKC Isozymes and their Activation by Endothelin-1 (ET-1) in the Mid-phase Bovine Corpus Luteum (CL) ................78

1. Introduction............................................... 78 
2. Materials and Methods...................................79

3. Results............................................... 85

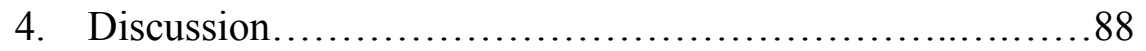

Chapter VI: Discussion and Future Studies................................99

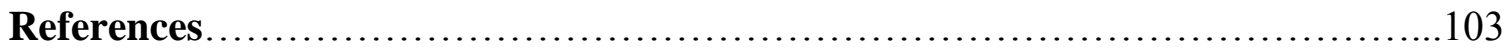

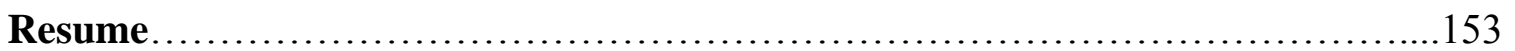




\section{List of Abbreviations}

$\left[\mathrm{Ca}^{2+}\right]_{\mathrm{i}}$ - Intracellular Cacium Concentration

$3 \beta$ HSD - 3 beta Hydroxy Steroid Dehydrogenase

ACAT - Microsomal acyl CoA: cholesterole acyl transferase

$\mathrm{ACE}$ - Angiotensin Converting Enzyme

AKAPs - A Kinase Anchoring Proteins

AKR - Aldoketo Reductase

ANP - Atrial Natriuretic Peptide

ANPT - Angiopoietins

AT - Angiotensin

bFGF - Basic Fibroblast Growth Factor

CEBP - CCAAt/Enhancer Binding Protein

$\mathrm{CL}$ - Cprous Luteum

Cox - Cyclooxygenase

CPGES - Cytosolic Prostaglandin E synthase

cPKC - conventional/classical Protein kinase C

CRE - cAMP Response Element

CREBP - cAMP Response Element Binding Protein

DAG - Diacyl Glycerol

DAX-1 - Dosage sensitive sex reversal; Adrenal hypoplasia congenital; X chromosome; gene 1

DDBX - Dihydrodiol Dehydrogenase 3

E2 - Estrogen

EC - Endothelial Cells

ECE - Endothelin Converting Enzyme

$\mathrm{EP}$ - Prostaglandin $\mathrm{E}_{2}$ receptor

ET - Endothelin

Fas L - Fas Ligand

$\mathrm{FP}-\mathrm{PGF}_{2 \alpha}$ receptor 
GC - Granulosa Cells

GF - Growth Factor

HDL - High Density Lipoprotein

HMG CoA - Hydroxy Methyl Glutaryl Coenzyme A

HPETE - Hydroperoxyeicosatetraenoic acid

IFN - Interferon

IGF - Insulin like Growth Factor

IL - Interleukin

$\mathrm{IP}_{3}$ - Phosphatidyl Innositol-3-Phosphate

KCIP 1 - Protein Kinase C Inhibitor Protein 1

LDL - Low Density Lipoprotein

LH - Luetinizing hormone

LHR - Leutinizing Hormone Receptor

LLC - Large luteal Cells

LTC 4 - Leukotriene C4

MAPK - Mitogen Activated Protein Kinase

MARCKS - Myristoylated Alanine Rich C Kinase Substrate

MPGES - Microsomal Prostaglandin E synthase

NCEH - Neutral Cholesterol Ester Hydrolase

$\mathrm{NO}$ - Nitric Oxide

nPKC - novel Protein Kinase C

OT - Oxytocin

OXO-PGR - 15-Oxo Prostaglandin 13- Reductase

P4 - Progesterorne

P450 scc - cytochrome P450 side chain cleavage enzyme

PBR - Peripheral-type Benzodiazepine Receptor

PDGF - Paltelet Derived Growth Factor

PG - Prostaglandin

PGDH - Prostaglandin Dehydrogenase

$\mathrm{PGE}_{2}-$ Prostaglandin $\mathrm{E}_{2}$

PGES - Prostaglandin E synthase 
$\mathrm{PGF}_{2 \alpha}$ - Prostaglandin F2 alpha

PGFM - 13,14-dihyro-15-keto Prostaglandin F2 alpha

PGFS - Prostaglandin F2 alpha Synthase

$\mathrm{PGG}_{2}$ - Prostaglandin $\mathrm{G}_{2}$

PGHS - Prostaglandin Endoperoxidase G/H Synthase

$\mathrm{PGI}_{2}$ - Prostaglandin $\mathrm{I}_{2}$

PGT - prostaglandin Transpoter

PKA - Protein Kinase A

PKC - Protein kinase $C$

$\mathrm{PLA}_{2}$ - Phospholipase $\mathrm{A}_{2}$

PLC - Phospholipase C

PMA - Phorbol 12-Myristate 13-Acetate

ppET - pre pro Endothelin

PS - Phosphatidyl Serine

RACKs - Receptors for Activated C Kinase

RICKs - Receptors for Inactive C Kinase

$\mathrm{SC}$ - Steroidogenic Cells

SCP - Sterol Carrier Protei

SF-1 - Steroidogenic Factor-1

SLC - Small luteal Cells

SRB-1 - Scavenger Receptor BI

StAR - Steroid Regulator Acute protein

TC - Theca cells

TF - Transcription Factor

TNF - Tumor Necrosis Factor

TNFR - Tumor Necrosis Factor Receptor

UOP - Utero-Ovarian Plexus

VDAC - Voltage Dependent Anion Channels

VEGF - Vascular Endothelial Growth Factor 


\section{Content of Figures}

\section{Chapter I: Literature Review}

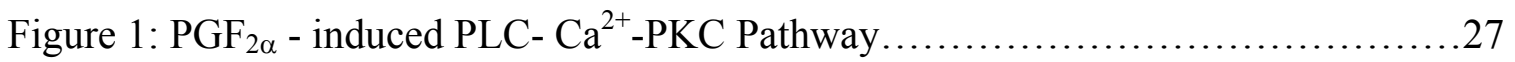

Figure 2: Primary structure of members of the PKC family showing subclasses and

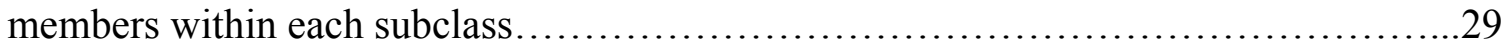

Figure 3: Intra-cellular Mechanism of PKC activation............................... 31

\section{Chapter III: Expression and Activation of Protein Kinase C Isozymes by Prostaglandin $F_{2 \alpha}$ in the Early and Mid-Luteal Phase Bovine Corpus Luteum}

Figure 1: Representative validation used in the semi quantitative Western blot analysis of the PKC isozyme array expressed in the bovine. Figure 1A demonstrate the amount of total sample protein needed to detect the luteal PKC isozymes; a representative Western blot corresponding to the PKC $\beta \mathrm{I}$ is shown in panel A. Panel B demonstrate the specificity of the Western blot obtained with the PKC $\beta$ I antibody. In this representative Western blot shown, the samples were run in duplicate at a protein concentration of 25 $\mu \mathrm{g}$. Lanes $\mathrm{c}$ and $\mathrm{d}$ correspond to the experimental conditions where the primary antibody was pre-incubated with an excess amount of antigenic peptide prior to its use in the Western blot. Panel $\mathrm{C}$ demonstrate the differential expression of $\mathrm{PKC} \varepsilon$ isozyme in the early- (day 4) and mid- (day 10) phase of the bovine CL. This representative Western blot demonstrates the amount of PKC $\varepsilon$ and actin expressed in protein samples prepare from bovine corpora lutea collected at $d-4(n=5$, lanes $1-5)$ and $d-10(n=5$, lanes 6-10) of the estrous cycle. The PKC isozyme specific antibody detected a protein band of approximately $80 \mathrm{kDa}$, whereas the actin antibody detected a protein band of about 43 $\mathrm{kDa}$ 
Figure 2: Semi quantitative analysis of the densitometry derived from the Western blot to reveal the array of PKC isozymes expressed in the $\mathrm{d}-4$ and $\mathrm{d}-10$ bovine CL. The $\mathrm{y}$-axis shows the ratio of the optical density (o.d.) for each PKC isozyme corrected by the detected o.d. for its corresponding actin. The data is shown as mean \pm SEM, values with differing letters denote statistically significant differences by two way ANOVA followed by the Tukey-Krame Honesty Significant Difference $(\mathrm{P}<0.01) \ldots \ldots \ldots \ldots \ldots \ldots \ldots \ldots . . .54$

Figure 3: Semi quantitative Western blot analysis of the time course distribution of PKC $\alpha$ in the cytosolic and membrane protein fractions isolated from one d-10 CL. Luteal tissue fragments were incubated in MEM-Hepes or MEM-Hepes containing $10 \mathrm{nM}$ $\mathrm{PGF}_{2 \alpha}$ for the indicated times. Panel A depicts the ratio of the optical density (o.d.) detected for the PKC isozyme corrected by the o.d. detected for actin. Panel B shows the representative Western blot used for the semi quantitative data shown in panel A.......55

Figure 4: Representative Western blot demonstrating PKC $\alpha$ in translocation in the d-10 luteal tissue after stimulation with $\mathrm{PGF}_{2 \alpha}$. Panel A reveals the exclusive cytoplasmic localization of the PKC $\alpha$ when the tissue was incubated with the control media, MEMHepes. Panel B demonstrates that after 10 minutes incubation of the luteal tissue with $\mathrm{PGF}_{2 \alpha}$ induced the appearance of PKC $\alpha$ in the membrane fraction. Panel $\mathrm{C}$ reveals the amount of actin associated with each sample of blot in panel A.......................56

\section{Chapter IV: Effects of Selective Protein Kinase C Isozymes in Prostaglandin $\mathrm{F}_{2 \alpha}$-induced $\mathrm{Ca}^{2+}$ Signaling and Luteinizing Hormone-Induce Progesterone Accumulation in the Mid-Phase Bovine Corpus Luteum}

Figure 1: Representative morphological characteristics of the three cell populations obtained from the dissociated bovine CL. Luteal steroidogenic (a and b) and endothelial 
cells were separated using magnetic Tosylactivated beads coated with BS-1 lectin as described in Materials and Methods. a) A small luteal steroidogenic cell (SLC), which typically had a diameter $<20 \mu \mathrm{m}$. b) A large steroidogenic cell (LLC); these cells typically had a diameter $>20 \mu \mathrm{m}$. c) Two luteal endothelial cells; these cells had one or two magnetic beads attached to their surface. All images were obtained using a x20 objective lens of an Olympus microscope equipped for Nomarsky microscopy. Bar in (a)

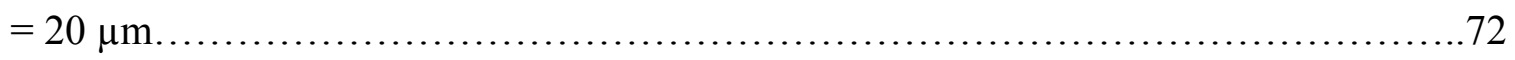

Figure 2: Specificity of the $\mathrm{PGF}_{2 \alpha}$-induced $\mathrm{Ca}^{2+}$ response and the $\mathrm{PKC} \varepsilon$ inhibitor. The cells were isolated from Day 10 bovine corpora lutea and prepared for fura-2 AM imaging of $\left[\mathrm{Ca}^{2+}\right]_{i}$ as described in Materials and Methods. Data are the relative fluorescence ratio $(340: 380 \mathrm{~nm})$ over time (in seconds). LLCs were exposed at the indicated time (arrows) to vehicle media (top), to $\mathrm{PGF}_{2 a}$ alone (1000 ng/ml; middle), and to $\mathrm{PGF}_{2 \alpha}(1000 \mathrm{ng} / \mathrm{ml})$ in the continuous presence of a $\mathrm{PKC}_{e}$-specific inhibitor (bottom). At the end of this trace, the cell was exposed to the calcium ionophore, A23187 $(1 \mu \mathrm{M})$ to demonstrate that even though the $\mathrm{PKC} e$ inhibitor prevented $\mathrm{PGF}_{2 \alpha}$ from eliciting its typical calcium signal, the ionophore A23178 was able to elicit a calcium response in the same cell............................................................ 73

Figure 3: Representative profiles of the $\mathrm{Ca}^{2+}$ responses induced by $1000 \mathrm{ng} / \mathrm{ml} \mathrm{PGF} 2 \alpha$ in single, large luteal cells (LLC; left) and small luteal cells (SLC) isolated from Day 4 bovine $\mathrm{CL}$ and the effects of PKC isozyme-specific inhibitors on this $\mathrm{PGF}_{2 \alpha}$-stimulated $\mathrm{Ca}^{2+}$ response. The cells were isolated and prepared for fura-2 AM imaging of $\left[\mathrm{Ca}^{2+}\right]_{\mathrm{i}}$ as described in Materials and Methods. Data are the relative fluorescence ratio (340:380 $\mathrm{nm}$ ) over time (in seconds). LLCs (left) and SLCs (right) were exposed at the indicated time (arrows) to $\mathrm{PGF}_{2 \alpha}$ alone (top; Control-LLC and Control SLC), to $\mathrm{PGF}_{2 \alpha}$ in the continuous presence of a conventional PKC inhibitor (middle; PKC (c)-LLC and PKC (c)-SLC) and $\mathrm{PGF}_{2 \alpha}$ in the continuous presence of a PKCe-specific inhibitor (bottom; PKC (e)-LLC and PKC (e)-SLC). In each panel, a line in the graph represents the trace of a single cell. The units used for the y-axis in the top left panel are different from all other panels in the figure. .74 
Figure 4: Representative profiles of the $\mathrm{Ca}^{2+}$ response induced by $1000 \mathrm{ng} / \mathrm{ml} \mathrm{PGF}_{2 \alpha}$ in single, large luteal cells (LLC; left) and small luteal cells (SLC; all others panels) cells isolated from Day 10 bovine CL and the effects of PKC isozyme-specific inhibitors on this $\mathrm{PGF}_{2 \alpha}$-stimulated $\mathrm{Ca}^{2+}$ responses. The cells were isolated and prepared for fura- 2 AM imaging of $\left[\mathrm{Ca}^{2+}\right]_{i}$ as described in Materials and Methods. Data are the relative fluorescence ratio $(340: 380 \mathrm{~nm})$ over time (in seconds). LLCs (left) and SLCs (right) were exposed at the indicated time (arrows) to $\mathrm{PGF}_{2 \alpha}$ alone (top; Control-LLC and Control SLC), to $\mathrm{PGF}_{2 \alpha}$ in the continuous presence of a conventional PKC inhibitor (middle; PKC (c)-LLC and PKC (c)-SLC) and $\mathrm{PGF}_{2 \alpha}$ in the continuous presence of a PKCe-specific inhibitor (bottom; PKC (e)-LLC and PKC (e)-SLC. In each panel, a line in the graphs represents the trace of a single cell. The scale units used for the y-axis in the top and middle left panels are different from all other panels in the figure...

Figure 5: Summary of the effects of conventional PKC [PKC (c)] and PKCe inhibitors $[\mathrm{PKC}(e)]$ on the $\mathrm{PGF}_{2 \alpha}$-stimulated rise in $\left[\mathrm{Ca}^{2+}\right]_{\mathrm{i}}$ in Day 4 and Day 10 LLCs and SLCs. The cells were isolated and prepared for fura-2 AM imaging of $\left[\mathrm{Ca}^{2+}\right]_{\mathrm{i}}$ as described in Materials and Methods. Cells were pretreated with either no inhibitors (control cells) or with $\mathrm{PKC}(\mathrm{c})$ - or $\mathrm{PKC}_{e}$-specific inhibitor. Values are presented as the mean $\pm \mathrm{SEM}$ of the fold increase in $\left[\mathrm{Ca}^{2+}\right]_{\mathrm{i}}$ induced by $\mathrm{PGF}_{2 \alpha}(1000 \mathrm{ng} / \mathrm{ml})$ from basal values observed before the stimulation with $\mathrm{PGF}_{2 \alpha}$. Statistical comparisons were made within cell type, developmental stage, and treatment; different letters on top of bars denote significantly different values $(P<0.05$ across treatments depicted by the bars; for Day $4, \mathrm{n}=116,224$, 225, 198, 189, and 208; and for Day 10, $\mathrm{n}=110,202,217,95,182$, and 205).........76

Figure 6: Effects of conventional PKC [PKC (c)] and PKC $\varepsilon$ inhibitors [PKC (є)] on $\mathrm{PGF}_{2 \alpha}$-actions on the basal and LH-stimulated progesterone accumulation in cultures of steroidogenic cells collected from Day 10 bovine CL. Progesterone accumulation was determined in culture media after $4 \mathrm{~h}$ of incubation in the following treatments: media alone (Media); $\mathrm{PGF}_{2 \alpha}(\mathrm{PG} ; 1000 \mathrm{ng} / \mathrm{ml}) ; \mathrm{PGF}_{2 \alpha}$ and LH (PG + LH; $1000 \mathrm{ng} / \mathrm{ml}$ and 100 ng/ml, respectively), $\mathrm{PGF}_{2 \alpha}, \mathrm{LH}$, and inhibitor conventional PKC [PKC (c) PG + LH; 
$1000 \mathrm{ng} / \mathrm{ml}, 100 \mathrm{ng} / \mathrm{ml}$, and $1 \mu \mathrm{M}$, respectively]; and $\mathrm{PGF}_{2 \alpha}, \mathrm{LH}$, and $\mathrm{PKC} e$ inhibitor [PKC (є) PG + LH; $1000 \mathrm{ng} / \mathrm{ml}, 100 \mathrm{ng} / \mathrm{ml}$, and $1 \mu \mathrm{M}$, respectively]. As explained for experiment 2 in Materials and Methods, all these treatments also contained saponin (50 $\mu \mathrm{g} / \mathrm{ml}$ ). Data are presented as the mean \pm SEM of four (Day 10) individual replicates (cows). Statistical comparisons were made across cell type, developmental stage, and treatment; different letters on top of bars denote significantly different values, $P<$ 0.05

\section{Chapter V: Cellular Source of Luteal PKC Isozymes and their Actication by Endothelian-1 (ET-1) in the Mid-phase Bovone Corpus Luteum (CL)}

Figure 1A: Semi-quantitative analysis of the amounts of mRNA encoding PKC $\varepsilon$ as a function of luteal development. Total RNA (200 $\mathrm{ng} /$ reaction) isolated from day $1(\mathrm{n}=3)$, day $4(n=3)$, day $10(n=4)$ and day $17(n=3)$ CL were used for the RT-CR assay. Data are presented as the \pm SEM of densitometric analysis of PKC $\varepsilon$ relative to GAPDH mRNA; values with different letters denote statistically significant differences $(\mathrm{P}<0.05) \ldots \ldots . .92$

Figure 1B: Representative RT-PCR products obtained by using different amounts of RNA / reaction (100 ng, $300 \mathrm{ng}$ and $500 \mathrm{ng}$ ) isolated from day 1 (lower panel) and day 10 (upper panel) CL using GAPDH and PKC $\varepsilon$ specific primers. The sizes of the amplified products for GAPDH and PKC $\varepsilon$ were 900 and $480 \mathrm{bp}$, respectively..................92

Figure 1C: Semi-quantitative analysis of amplified PKC $\varepsilon$ mRNA as a function of different amounts (100 ng, $300 \mathrm{ng}$ and $500 \mathrm{ng})$ of RNA / reaction from day $1(\mathrm{n}=3)$ and day $10(n=3)$ CL. Data are presented as the \pm SEM of densitometric analysis of PKC $\varepsilon$ relative to GAPDH mRNA; values with different letters denote statistically significant

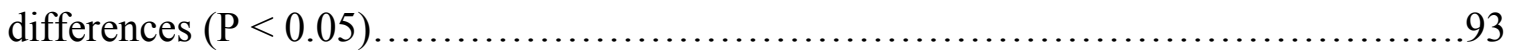

Figure 2A: Representative Western blot of PKC $\alpha, \operatorname{PKC} \varepsilon$ and actin from enriched sterroidogenic and endothelial cells collected from day $10 \mathrm{CL}(\mathrm{n}=3)$. The middle panel 
reveals the exclusive localization of PKC $\varepsilon$ in the steroidogenic cells. $10 \mu \mathrm{g} /$ lane of protein were used for the western blots. Each lane indicates individual CL..............93

Figure 2B: Semi-quantiative analysis of Western blots to reveal the cellular source of luteal PKC isozymes in day $10 \mathrm{CL}(\mathrm{n}=3)$. The $\mathrm{y}$-axis shows the ratio of optical density (O.D.) of each luteal PKC isozymes corrected by the detected O.D. for its corresponding actin. Data are presented as the \pm SEM; values with different letters denote statistically significant differences $(\mathrm{P}<0.05)$.

Figure 3: Immunohistological detection of PKC $\varepsilon$ in frozen sections of day $10 \mathrm{CL}$. Panel A is a lower magnification view of the field shown in panel C. Panel B shows a negative control using a consecutive section to that used in panel A but omitting the primary antibody in the detection protocol. The arrow with the number 1 in panel $\mathrm{C}$ indicates the lumen of a blood vessel. The arrow with the number 2 indicates an immunopositive SLC, while the arrowhead represents an immunopositive LLC. Microphotographs shown in panels $\mathrm{A}$ and $\mathrm{B}$ were taken at the same magnification. The bars in panel $\mathrm{A}$ and $\mathrm{C}$

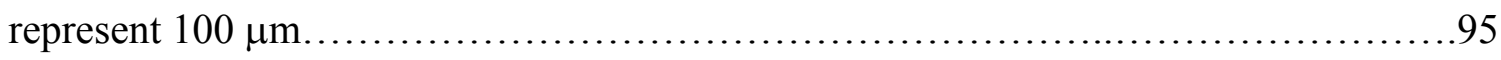

Figure 4A: Representative Western blot demonstrating ET-1 stimulated PKC $\varepsilon$ redistribution in day 10 luteal tissue $(n=5)$. Right top panel shows the exclusive cytoplasmic localization of PKC $\varepsilon$ when the tissue was incubated with control media, MEM-Hepes. Left top panel demonstrates that a 10 min incubation of the luteal tissue with ET-1 (100 nM) induced the appearance of PKC $\varepsilon$ in the membrane fraction. Lower left and right panel show the amount of actin associated with each sample. Each lane indicates individual CL. Amount of protein used for the western blots were $10 \mu \mathrm{g} /$ lane .96

Figure 4B: Semi-quantitative analysis of ET-1 stimulated PKC redistribution. The y-axis represents the actin corrected ratio of the optical density (O.D.) detected for each PKC isozyme in the membrane and cytosolic fractions $(\mathrm{M} / \mathrm{C})$. Data are presented as the \pm 
SEM; values with different letters denote statistically significant differences $(\mathrm{P}<$ $0.05)$ .97

Figure 5: Effects of conventional PKC [PKC (c)] and PKC $\varepsilon$ inhibitors [PKC (e)] on ET$1(100 \mathrm{nM})$ actions on $\mathrm{P}_{4}$ accumulation in cultures of steroidogenic cells collected from (A) Day 4 and (B) Day 10 bovine CL. $\mathrm{P}_{4}$ accumulation was determined in culture media after $4 \mathrm{~h}$ of incubation. Data are presented as the \pm SEM; values with different letters

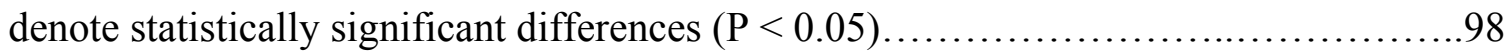

\section{Content of Table}

1. Chapter III: Expression and Activation of Protein Kinase C Isozymes by Prostaglandin $F_{2 \alpha}$ in the Early and Mid-Luteal Phase Bovine Corpus Luteum

Table1. Summary of the PGF2 $\alpha$-stimulated cellular redistribution of the PKC

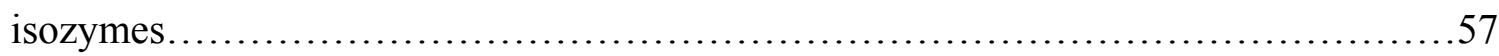




\section{Acknowledgement}

This work would not have been possible without the help and guidance of my advisor, Dr Jorge A. Flores. Dr. Flores not only guided me with the experimental designs but sowed the seeds of logical thinking and the ability to ask simple questions in me. He made me realize that graduate training is more than performing experiments and taught me simple and effective communication skills to convey the most critical scientific data. Now, looking back I greatly appreciate all his patience and the time he spent in teaching me how to write. In true sense he has been a friend, philosopher and guide to me. He is the ideal mentor a graduate student can dream of.

There are very few people one comes across in life who greatly influence ones life. Dr. Inskeep is one such person in my life. His love, enthusiasm and dedication for science were a source of constant motivation to me. I thank him for making me familiar with the history and literature of reproductive physiology. I am grateful to him for his continuous help and suggestions in the experimental designs, tissue collection and writing of various papers. I am fortunate to have been able to learn from one of the legends in the field of reproductive physiology.

I also thank my other committee members, Dr. Matthew Wilson, Dr. Christy Foran and Dr. Keqiang Wu for their valuable suggestions throughout my graduate study. I am appreciative of all the help I received from a number of graduate students at different stages of this research: Ekta Choudhary for teaching me cell culture and helping me with the calcium experiments; Brandon Lingenfelter, Justin Rhinehart and Aimee Wurst for tissue collection and Melanie Starbuck for teaching me radio immuno assay. I thank Umesh Krandhikar and Sanjay Cherikuri for their support, advice and for all the lively long discussions we used to have from which I learned a lot. Finally, last but not the least I am grateful to my wife Anindita for always being there for me, and providing me with all the support I needed during all those days when I was ready to quit.

\section{"If I have seen further it is by standing on the shoulders of giants"}




\section{Chapter I: Literature Review}

\section{History:}

In 1642 Regnier de Graaf reported the appearance of "globules" after coitus in the ovary of rabbits [Corner GW, 1943]. It was Marcello Malphighi who in 1681 [Malphighi M, 1689] termed these "globular bodies" as Corpora (bodies) lutea (yellow) or Corpus Luteum (CL). In 1897, Beard [Beard J, 1897] first suggested the involvement of the CL in the suppression of ovulation and estrus during pregnancy. The very next year, Prenant [Prenant LA, 1898] proposed that the CL might be a gland involved in secretion that is associated with pregnancy.

Nearly two centuries after the introduction of the term "Corpus Luteum", in 1901 two students of Gustav Born, Ludwig Fraenkel in Germany [Fraenkel L, 1901] and Vilhelm Magnus in Norway [Magnus V,1901] reported the precise physiological function of the CL. These two researchers independently demonstrated the importance of the CL in implantation and in the subsequent maintenance of pregnancy in rabbits. Thereafter, Corner and Allen [Corner GW et al, 1929] using relatively pure alcoholic extract of the CL prepared from sows demonstrated that this extract was able to maintain pregnancy in ovariectomized rabbits. In 1934, four independent laboratories, Wintersteiner and Allen [Wintersteiner O and Allen WN, 1934], Slotta et al [Slotta KH et al, 1934], Butenandt and Westphal [Butenandt A, Westphal U, 1934] and Hartmen and Wettstein [Hartmen H, Wettstein A, 1934], claimed to isolate the pure crystalline hormone secreted by the CL and named it Progesterone (P4).

\section{Development of the CL}

During ovulation, the preovulatory surge of Luteinizing hormone (LH) from the anterior pituitary results in the rupture of the mature follicle and expulsion of the ovum. The residual follicular cells, (theca and granulosa cells) in the ovary, under the influence of LH and various mitogenic factors undergo hypertrophy and hyperplasia. The wall of the follicle collapses into folds along with invasion of capillaries, while various angiogenic factors result in neovascularization. These events lead to the formation of a transient endocrine gland called the Corpus Luteum. The major function of the CL is to 
produce P4 that is essential for the maintenance of pregnancy. However, if pregnancy does not occur, timely regression of the CL is necessary for normal ovarian cyclicity.

\section{Cellular Composition, Cell morphology, Cell division and Differentiation:}

The CL is comprised of theca (TC) and granulosa (GC) derived luteal steroidogenic cells as well as endothelial cells (EC), fibroblasts, pericytes and cells from blood [Channing CP, 1969a; Channing CP, 1969b]. In domestic animals, the cells derived from the GC are called large luteal cells (LLC) while those derived from the TC are known as small luteal cells (SLC) [Niswender GD and Nett TM, 1994]. These luteal steroidogenic cells differ not only in origin but also in morphology and physiology. The LLC are greater than $20 \mu \mathrm{m}$ in size with spherical nuclei and high amounts of rough endoplasmic reticulum (ER). These cells are responsible for basal P4 synthesis, have less LH receptor (LHR) and are less sensitive to LH stimulation (require high LH concentration). These cells also have higher amounts of estrogen $\left(\mathrm{E}_{2}\right)$ receptors and prostaglandin $\mathrm{F}_{2 \alpha}\left(\mathrm{PGF}_{2 \alpha}\right)$ receptors [Farin $\mathrm{CE}$ et al, 1986]. In contrast, SLC are smaller than $20 \mu \mathrm{m}$ with irregular nuclei and are devoid of rough ER [Fitz A et al, 1982; Wiltbank M C, 1994]. These cells are responsible for LH-stimulated P4 synthesis [Koos $\mathrm{RD}$ et al, 1981]. There is also evidence that some SLC may transform into LLC with the development of the CL [Alila HW and Hansel W, 1984].

Although the CL is a transient endocrine gland, it is one of the most highly vascularized tissues in the body [Reynolds LP et al, 1998; Redmer DA et al, 1996] with the EC constituting about $50 \%$ of the total luteal cell population. In the CL, the EC are involved in neovascularization [Spanel-Borowski K and Fenyves A, 1994a], inter-cellular communication and steroidogenesis [Girsh E et al, 1995]. Proliferation and morphological changes of EC are important regulatory factors for luteal development. Over the past few years, microvascular EC have been isolated and cultured from the CL of different species: rabbit [Bagavandoss P et al, 1991], pig [Plendl J et al, 1996b], sheep [Rodgers RJ et al, 1982], cow [Spanel-Borowski K and Fenyves A, 1994a; SpanelBorowski K and van der Bosch J, 1990, Girsh E et al, 1995], rhesus monkey [Christenson LK et al, 1996] and humans [Ratcliffe KE et al, 1999]. These studies have led to the identification of 5 distinct sub-types of EC, namely Types 1,2,3,4 and 5 [Spanel- 
Borowski K and Fenyves A, 1994a; Spanel-Borowski K and van der Bosch J, 1990]. These sub-types of EC have been characterized by differences in morphology, surface molecule expression and function [Spanel-Borowski K, 1991]. In the bovine CL, the microvascular EC have been classified based on the presence or absence of cytokeratin filaments [Spanel-Borowski K and Fenyves A, 1994a; Spanel-Borowski K et al, 1994b; Spanel-Borowski K et al, 1990]. These two different EC types differ in their expression and function during luteal development. The cytokeratin positive EC are expressed predominantly in the early CL and their expression decreases during the mid-late stage [Ricken AM et al, 1995]. These EC are involved in the sprouting of capillaries and in the formation of branching points during neovasculariztion at the early developmental stage of the CL. Moreover, the CL of pregnancy is completely devoid of the cytokeratin positive EC [Ricken AM et al, 1995]. Plendl et al [Plendel J et al, 1996a] proposed that the EC isolated from the bovine CL during pregnancy produce specific angiogenic factors that are absent or present in limited amounts in EC isolated from the CL of the estrous cycle. Less is known about the expression and function of the cytokeratin negative EC. However, the selective presence of different EC types during luteal development may be involved in the regulation of luteal physiology. For example, there is a controversy in the literature about the expression of $\mathrm{PGF}_{2 \alpha}$ receptor (FPr) in the EC. It is possible that these EC types may differ in their expression of FPr [Aust BEG et al, 1999; Lehmann I et al, 2000] and presence / absence of these EC types during luteal development may be one of the factors regulating the life span of the CL. Thus, further studies are needed to investigate the physiological functions of these different types of EC.

A characteristic of early CL development is rapid tissue growth and cellular proliferation. The growth of the CL in many cases has been compared to that of rapidly growing tumors [Jablonka-Shariff A et al, 1993]. For example, the weight of a day 3 bovine CL is about $640 \mathrm{mg}$, while on day 14, the average weight will be $5.1 \mathrm{~g}$ [Fields MJ et al, 1996]. Most of this increase in tissue mass has been attributed to hypertrophy and mitotic division of LLC, SLC, EC and fibroblasts. The LLC do not increase in number but in size. In contrast SLC and endothelial cells undergo rapid increase in number [Reynolds LP et al, 1994]. The factors responsible for the regulation of cell proliferation are basic fibroblast growth factor (bFGF) [Neufeld G et al, 1987], platelet derived growth 
factor (PDGF) [Khachigian LM et al, 1996], insulin-like factor I (IGF-I) [Juengel JL et al, 1997], heparin binding growth factor [Grazul-Bilska AT et al, 1992] and vascular endothelial growth factor (VEGF) [Redmer DA et al, 1996]. Little is known about the specificity of these factors with respect to proliferation of specific luteal cell types. VEGF is considered as the main mitogenic regulator of EC during luteal neovascularization. Capillary network accounts for $22 \%$ of the total CL volume [Dharmarajan AM et al, 1985] and the CL has greater blood flow rate per unit tissue than any organ [Reynolds LP et al, 1998; Redmer DA et al, 1996].

\section{Angiogenesis}

Angiogenesis is a critical aspect of growth and function of the CL [Reynolds LP et al, 1992]. During luteal development, VEGF and bFGF [Reynolds LP et al, 1998] are two main angiogenic factors responsible for neovascularization [Gospodaorwicz D et al, 1985]. VEGF is involved in vascular permeability, EC protease production, migration and proliferation, all of which are integral parts of angiogenesis [Ferra $\mathrm{N}$ et al, 1997]. Also, in the bovine CL, VEGF receptors are localized exclusively in EC [Berisha B et al, 2000]. It is well established that VEGF acts via fms-like tyrosine kinase-1 receptor (Flt-1) and fms-like kinase insert domain-containing receptor (Flk-1) [Fong GH et al, 1995]. In the early bovine CL, VEGF and its receptors are highly expressed [Redmer DA et al, 1988; Redmer DA et al, 1996]. Based on in situ hybridization and immunohistological studies on the bovine CL, it is known that VEGF is mainly present in steroidogenic cells while Flt-1 and Flk-1 are present only in EC [Berisha B et al, 2000]. VEGF expression can be stimulated by bFGF, hormones and cytokines involved in angiogenesis [Ferra $\mathrm{N}$ et al, 1997]. Ablation of VEGF and VEGF receptor gene expression by knock out strategies [Shalaby F et al, 1995] and disrupting VEGF function with neutralizing monoclonal antibodies [Kim KJ et al, 1993] have shown that VEGF plays a role in the organization and maintenance of the microvasculature [Carmeliet P et al, 1996]. Reynolds and Redmer [Reynolds LP et al, 1998; Reynolds LP et al, 1999] have proposed a model of vascularization of the $\mathrm{CL}$ that is different from the vascularization in the growing follicles. The follicles are supplied by one artery which forms 3-4 arterioles in the theca externa. Entering the theca interna, the arterioles break up into a rich network of 
capillaries that build a basket-like network around the avascular stratum granulosum [Plendl J, 2000]. The basement membrane, forms a barrier within the follicular wall and prevents the thecal vasculature from invading the stratum granulosum. After ovulation, the breakdown of the basement membrane results in the invasion of the theca-derived pericytes, into the granulosal region. According to the model proposed by Reynolds and Redmer, pericytes of the thecal capillaries are the initial vascular cells that produce VEGF. The proliferation and migration of these pericytes are stimulated by GF, FGF-2 and PDGF produced by the GC. The pericytes then produce VEGF, which in turn stimulates the migration of the theca-derived EC into the granulosal-derived region. Subsequent interaction between pericytes and EC leads to the formation of a mature capillary bed of the luteal parenchymal lobule [Reynolds LP et al, 1998; Reynolds LP et al, 1999].

Additional angiogenic factors like angiopoietins [Tsigkos S et al, 2003] play an important role in the regulation of vascular development during early stages of the CL. Angiopoietin-1 and 2 (ANPT-1, ANPT-2) act via Tie 2 receptor (tyrosin kinase with immunoglobulin and EGF homology domains) [Goede $\mathrm{V}$ et al, 1998]. ANPT-1 is necessary to maintain and stabilize blood vessels, while ANPT-2 destabilizes vascular structures. Since both ANPT-1 and ANPT-2 bind to same Tie 2 receptor, the ratio of ANPT-2/ANPT-1 plays a critical role in maintaining vascular stability. VEGF and ANPT-1 act synergistically in maintaining vascular networks and can reverse the destabilizing effects of ANPT-2 [Yancopoulos GD et al, 2000]. In vitro studies have demonstrated that angiopoietin-1 stimulates sprouting and maturation of blood vessels [Tsigkos S et al, 2003; Goede V et al, 1998]. In the bovine CL, high amounts of angipoietin-1 mRNA were found to be present in developing and fully functional CL of the estrous cycle [Goede V et al, 1998].

In the bovine [Schams D et al, 1994; Zheng J et al, 1993; Berisha et al, 2002] and ovine CL [Grazul-Bilska AT et al, 1992; Jablonka-Shariff A et al, 1997], other factors like bFGF (FGF-1 and FGF-2) and angiotensin II are involved in luteal development, vascularization and steroidogenesis. In this section, only luteal development and vascularization will be discussed. Primarily, in the early luteal phase, FGF-2 stimulates EC proliferation [Gospodarowicz D et al, 1986]. Neutralization of FGF-2 action greatly 
decreases mitogenic activities of EC in bovine, porcine and ovine CL [Redmer DA et al, 1996; Reynolds LP et al, 1998]. In luteal parenchymal cells, FGF-1 and FGF-2 acts via FGF receptor. It has been suggested that binding of FGF-2 with FGFR in luteal microvessels is important for protection of luteal tissue against regression [Reynolds LP et al, 1998]. Expression of FGF-1 significantly increases in the mid-late CL with higher localization to larger microvessels [Reynolds LP et al, 1998]. The exact role of FGF-1 in luteal development is unclear.

A potential role of angiotensin-II in early CL development has been suggested in many studies. In the bovine luteal EC, angiotensin-I is converted into angiotensin II by angiotensin converting enzyme (ACE) [Schauser $\mathrm{KH}$ et al, 2000]. In primary cell culture of bovine luteal cells, angiotensin II has been shown to stimulate mRNA of bFGF in bovine luteal cells [Stirling $D$ et al, 1990]. In vivo studies with bovine CL have demonstrated that angiotensin II stimulates expression of VEGF and FGF-2 [Berisha B et al, 2002]. These actions of angiotensin in the CL occur via angiotensin II type 1 (AT1R) and type 2 (AT2R) receptors that are expressed in steroidogenic cells and EC [Hayashi K et al, 2000]. Another vasoactive peptide, atrial natriuretic peptide (ANP) enhances release of angiotensin II, thereby suggesting its involvement in the angiogenic process during luteal development [Acosta TJ et al, 2000].

\section{Luteal Steroidogenic Pathway}

Progesterone (P4) is the major steroid of the CL that plays a central role in reproduction, being involved in implantation, pregnancy and in many other physiological functions. Before ovulation, estrogen (E2) is the primary steroid secreted by the ovary. A major alteration of steroidogenic pathway occurs following luteinization of GC and TC that makes P4 the steroid of the CL. In the cells undergoing differentiation during luteinization, enzymes necessary for P4 synthesis are upregulated. For example, in the bovine system, expression of P450 side chain cleavage enzyme (P450 scc) and 3-beta hydroxysteroid dehydrogenase ( $3 \beta-\mathrm{HSD}$ ) involved in conversion of cholesterol to P4 are upregulated while enzymes like $17 \alpha$-hydroxylase, cytochrome P-450 and aromatase cytochrome P-450 involved in the conversion of P4 to E2 are downregulated [Bao B et al, 
1998]. Cholesterol is the substrate for P4 synthesis. The CL is capable of de novo cholesterol synthesis. However this method plays a minor role in steroidogenesis in the CL due to low expression of HMG-CoA reductase and other key enzymes of cholesterol biosynthetic pathway [Gwynne JT et al, 1982]. Majority of the cholesterol for P4 synthesis in the CL is obtained from low density lipoprotein (LDL) and high density lipoprotein (HDL). Also, cholesterol esterase has been shown to hydrolyze stored cholesterol ester for P4 synthesis in the CL [Johnson WJ et al, 1997].

\section{Cholesterol transport into and within cells:}

Transport of cholesterol into the cells is the first challenge for P4 synthesis by luteal cells. Whether LDL or HDL serves as the cholesterol source for luteal steroidogenesis is species dependent. Transport of LDL across the cell membrane occurs via receptormediated endocytosis resulting in formation of LDL-receptor-clathrin coated pit complex [Brown MS et al, 1986]. In contrast, extracellular HDL enters the cell by binding to plasma membrane bound HDL binding protein. In mice, cloning of scavenger receptor BI (SR-BI) identified this receptor as the HDL receptor [Acton S et al, 1996]. Targeted deletion of this gene resulted in infertility in female mice and reduced lipid levels in the CL. However, this decline in fertility could not be attributed to reduced steroid output, as endocrine profiles were normal. This observation led to the suggestion that de novo synthesis of cholesterol may have compensated for the absence of HDL delivery [Acton S et al, 1996]. The mechanisms of uptake of lipoproteins by cells are poorly understood. Cholesterol esters, stotage sites for P4 synthesis are formed by microsomal acyl coenzyme A: cholesterol acyltransferase (ACAT). The cholesterol esters accumulate in the rough ER and with increased concentration bud off into cytoplasm as lipid droplets.

Inside the cell, receptor-mediated endocytosis of lipoprotein particles result in the formation of endosomes. Endosomal lysosomes recycle the lipoprotein receptors to the plasma membrane, while lysosomal degradation of LDL/HDL releases cholesterol into cholesteryl ester droplets. These cholesteryl ester droplets are transported to the mitochondria. The droplets are hydrolyzed by the extralysosomal enzyme, neutral cholesterol ester hydrolase (NCEH) into free cholesterol [Christenson LK et al, 2003] and 
transported across the mitochondrial membrane [Voet D and Voet J, 1995] with the help of various proteins.

The cholesteryl ester droplets are transported to the mitochondria with the involvement of the cytoskeleton. In rat adrenal cells, inhibitors of microtubules and microfilaments assembly prevent accumulation of cholesterol [Crivello JF et al, 1978] while phosphorylation status of cytoskeletal proteins plays an important role in steroid transport [Ikonen E et al. 1997]. Sterol binding proteins also are suggested to play a role in the transport of cholesterol to the mitochondria [Scallen TJ et al, 1985; Jefcoate CR et al, 1992]. The exact mechanism of cholesterol transport from the plasma membrane to the mitochondria involving cytoskeletal proteins is poorly understood.

\section{Cholesterol transport across mitochondrial membranes:}

Cholesterol transport from outer to inner mitochondrial membrane involves different proteins, namely steroidogenic acute regulator protein (StAR), sterol carrier protein (SCP-1) and peripheral-type benzodiazepine receptor (PBR). This process has been suggested to be the key regulatory step in P4 synthesis [Stevens VL et al, 1993]. The StAR protein is thought to play a major role in this process. It consists of a $37 \mathrm{kDa}$ precursor and a $30 \mathrm{kDa}$ mature form that was first observed in ACTH-stimulated adrenocortical cells [Krueger RJ et al, 1983]. Full length StAR protein was first cloned from MA-10 mouse Leydig cells [Clark BJ et al, 1994]. Transfection of MA-10 cells and COS-1 cells with StAR resulted in increased conversion of cholesterol to pregnenolone and steroid production [Lin D et al, 1995]. These experiments directly demonstrated the role of StAR in the steroid production pathway [Stocco DM et al, 1996].

The expression of StAR in the luteal steroidogenic cells is an indication of luteinization. Before ovulation, StAR is practically absent in GC as a result of which GC are unable to metabolize and synthesize P4 from cholesterol precursors. In contrast, StAR expression is found in TC that are involved in conversion of cholesterol to androgens [Pescador $\mathrm{N}$ et al, 1996]. Expression of StAR mRNA and protein is highest in early and mid-luteal phase of ovine CL, while it declines in the late luteal phase [Juengel JL et al, 1995a]. Based on this observation, it has been proposed that regulation of StAR gene 
expression and activity might be an essential component of luteal regression [Niswender GD, 2002].

In domestic animals, LH induces the expression of StAR in the early luteal stage [Juengel JL et al, 1999]. Binding of LH to its G-protein coupled receptor activates the cAMP - protein kinase A (PKA) pathway that results in the expression of StAR [Juengel $\mathrm{JL}$ et al, 1999]. In contrast, during luteal regression it is believed that $\mathrm{PGF}_{2 \alpha}$ interferes with StAR expression, thereby disrupting P4 synthesis [Niswender GD, 2002]. The mechanism by which $\mathrm{PGF}_{2 \alpha}$ inhibits StAR expression is poorly understood. Thus, the transcriptional regulation of StAR has been an area of active research. Steroidogenic factor-1 (SF-1/AdBP/NR5A-1), a member of the nuclear receptor family, is activated by PKA and plays a central role in StAR gene expression [Parker KL et al, 1997]. Several SF-1 binding sites are present in the StAR promoter region that are essential for both basal and cAMP dependent regulation [Sandoff TW et al, 1998; Wooton-Kee CR et al, 2000; Rust W et al, 1998]. The method by which SF-1 binding sites confers cAMPresponsiveness and the regulatory factors involved in SF-1 function (i.e., ligands, phosphorylation, and coactivators) are not completely understood [Christenson LK et al, 1998; Hammer GD et al, 1999; Ito M et al, 1998]. Also found in the StAR promoter region are cis elements responsive to CCAAT/enhancer-binding proteins (CEBP). These CEBP response elements that are needed for cAMP-stimulated transcription have been identified in murine [Wooton-Kee CR et al, 2000; Silverman E et al, 1999], bovine [Rust W et al, 1998] and human [Christenson LK et al, 2001] StAR promoters. CEBP and SF-1 exert a synergistic effect on cAMP dependent StAR activity [Reinhart AJ et al, 1999]. Electrophorectic mobility shift assays and promoter analysis studies have shown a role of GATA-4 and a cooperative mediation of CEBP and GATA-4 in stimulation of basal and cAMP dependent StAR gene expression [Tremblay JJ et al, 2002; Tremblay JJ et al, 2003]. Another, transcription factor, DAX-1 (dosage sensitive sex reversal; adrenal hypoplasia congenita; $\mathrm{X}$ chromosome; gene 1), a member of the nuclear hormone receptor family, inhibits StAR gene expression by binding to a hairpin structure in a region of single stranded DNA found in the promoter region of the StAR gene [Zazopoulos E et al, 1997]. It has been proposed that $\mathrm{PGF}_{2 \alpha}$ activates DAX-1 and inhibits StAR expression [Diaz FJ et al, 2002]. Recently P4 has been reported to stimulate StAR 
expression in MA-10 cells, the mechanism of which is still unknown [Schwarzenbach $\mathrm{H}$ et al, 2003]. However, classical P4 receptors are thought not to be involved in this process as MA-10 cells are devoid of these receptors.

In addition to transcriptional control, StAR protein is regulated directly [Bose $\mathrm{H}$ et al, 2002]. Truncation studies have demonstrated that the c-terminal end of StAR play an important role in cholesterol transport [Arakane F et al, 1996]. Steroid stimulating properties of MLN 64 protein, known to have significant homology with the C-terminal region of StAR further demonstrated the importance of this region in StAR activity [Watari $\mathrm{H}$ et al, 1997]. In ovine $\mathrm{CL}$ it is proposed that StAR has a mitochondrial targeting site (MTS) and a cholesterol binding site (CBS) [Niswender GD et al, 2000]. Six potential phosphorylation sites, 3 in MTS and 3 in CBS have been proposed in ovine StAR. Sequence analysis studies have reported the presence of PKA/CAM kinase II and PKC phosphorylation sites in StAR protein [Niswender GD et al, 2000]. In ovine luteal cells, phosphorylation of esterase and StAR by PKA increases the level of free cholesterol available for P4 synthesis [Caffrey JL et al, 1979]. In mouse, mutational studies of phosphorylation sites revealed that phosphorylation of StAR by PKA/CAM kinase II at positions 194/195 significantly increases its biological activity [Arakane F et al, 1997]. Thus, it is likely that in the early luteal stage LH, via cAMP-PKA pathway, induces StAR expression and activity, thereby stimulating P4 synthesis. In contrast, during luteal regression, $\mathrm{PGF}_{2 \alpha}$ inhibits StAR expression and activity, thereby disrupting P4 synthesis.

The interaction of StAR with other proteins, mainly PBR and endozepine is unclear. [Hauet T et al, 2002; Miller WL et al, 1999]. Targeted deletion of PBR resulted in loss of steroidogenic capacity in leydig cells, which was restored on supplying the cells with membrane-permeable cholesterol analogues [Papadopoulos V et al, 1997b]. Also mutations in PBR at Y153 and R156 caused significant reduction in the interaction between PBR and cholesterol. [Li H et al, 1998]. PBR appears to be associated with voltage dependent anion channel (VDAC) and molecular modeling indicates that PBRVDAC complex forms a pore permeable to cholesterol that spans the mitochondrial membrane [Papadopoulos V et al, 1997a]. The expression of PBR in steroidogenic cells was found to be independent of hormonal regulation, but the affinity of the receptor 
greatly increased after hormone treatment [Papadopoulos V et al, 1995]. Endozepine, the natural ligand of PBR is thought to play a critical role in cholesterol transport. Targeted deletion of this molecule in MA-10 and R2C cells resulted in inhibition of trophic hormone stimulation and reduction of basal steroidogenesis [Boujard $\mathrm{N}$ et al, 1993]. Understanding the interaction of these three proteins, PBR, StAR and endozepine in the CL needs further investigation.

\section{Regulation of P4 synthesis by Luteotropic Factors: Effects of LH}

In domestic animals and primates, LH is the major luteotropic hormone. A luteotropin is defined to be a substance that promotes the growth and development of the CL and stimulates $\mathrm{P} 4$ synthesis. The requirement for pulsatile release of LH from the pituitary for the development and maintenance of the CL varies from spieces to spieces. In the sheep [McNeilly AS et al, 1992] P4 synthesis is independent of LH pulses and can be maintained with basal LH secretion. In bovine CL [Peters KE et al, 1994], pulsatile LH secretion is a critical factor during luteal development. However, once the CL has developed, basal LH production is sufficient for P4 synthesis. In contrast, primates [Fraser HM et al, 1986] need pulsatile LH release throughout the luteal phase in order to maintain the CL [Zeleznik AJ et al, 1994]. Hypophysectomy in ewes [Farin CE et al, 1990] decreased P4 synthesis [Juengel JL et al, 1995b] with reduced amounts of mRNA encoding StAR, P450sce and 3 $\beta$-HSD [Juengel JL et al, 1995a]. Hypophysectomy did not have any affect on cholesterol intake or on HDL/LDL receptor expression [Tandeski

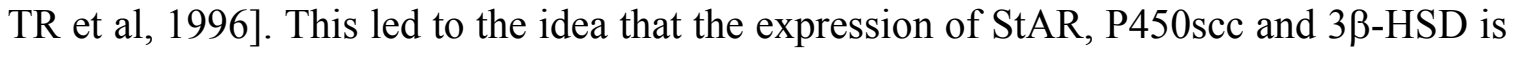
LH dependent. In luteal cells, LH acts via a G-protein coupled receptor that activates the cAMP-PKA pathway.

In vitro studies have demonstrated that $\mathrm{LH}$ receptor is also linked to the PLCPKC-Calcium pathway in luteal [Alila HW et al, 1989; Davis JS et al, 1996] and granulosal cells [Flores JA et al, 1998]. In ruminants, $80 \%$ or more of the circulating P4 is derived from basal/constitutive P4 synthesis in LLC. A hypothesis has been proposed [Diaz FJ et al, 2002], that LLC contain an extra PKA catalytic subunit in relation to its 
regulatory subunit. This extra subunit remains constitutively active and causes tonic PKA phosphorylation in LLC [Diaz FJ et al, 2002]. Also, it has been proposed that the presence of high a concentration of endozepine in LLC may play a role in increased basal P4 production in these cells [Niswender GD, 2002]. In LLC, both basal and LHstimulated P4 production is dependent on calcium. In contrast, in SLC, LH-stimulated but not basal, P4 synthesis is calcium dependent [Alila HW et al, 1989; Alila HW et al, $1988 b]$.

\section{Effects of oxytocin (OT) and prostaglandins (PGE, $\mathrm{PGI}_{2}$ and $\left.\mathrm{PGF}_{2 \alpha}\right)$}

Expression of OT receptors [Schams D, 1992; Evans JJ, 1996] and their localization in LLC and SLC of bovine CL are well established [Kruip TA et al, 1985]. Luteinization triggers production of ovarian OT that influences steroidogenesis [Schams D, 1987]. In vitro studies [Miyamoto A et al, 1991] have shown that OT is a potent luteotropin in the early developmental stage of the CL [Schams D et al, 1995a; Schams D, 1996]. This notion is further supported by other studies that have shown that cell-tocell contact plays an important role for the stimulation of P4 by OT [Okuda K et al, 1998; Sakumoto R et al, 1996].

It is well established that prostaglandins, especially $\mathrm{PGE}_{2}$ and $\mathrm{PGI}_{2}$, play important roles in luteal protection [Hansel W et al, 1991; Milvae RA et al, 1980]. These prostaglandins are present in higher amounts in the early CL and are proposed to be involved in luteal development [Milvae RA et al, 1983]. In cows, indomethacin (PGH synthase I inhibitor) treatment in the early luteal phase significantly lowered P4 synthesis throughout the life span of the CL [Milvae RA et al, 1985]. Moreover, prostacyclin injection directly into the CL dramatically increased P4 production [Milvae RA et al, 1980].

Both $\mathrm{PGE}_{2}$ [Fitz TA et al, 1984a] and $\mathrm{PGI}_{2}$ [Fitz TA et al, 1984b] have been shown to increase P4 synthesis in many species via an increase in cAMP [Alila HW et al, 1988a]. PGI $_{2}$ receptors are present in both LLC and SLC [Chegini NZ et al, 1990; Chegini NZ et al, 1991]. However, the exact mechanism by which $\mathrm{PGI}_{2}$ is luteotropic is poorly understood. 
There are four $\mathrm{PGE}_{2}$ receptor sub-types EP1, EP2, EP3 and EP4 [Narymiya S et al, 1999]. EP2 and EP4 receptors are coupled to the adenylate cyclase-cAMP-PKA signaling pathway. EP1 receptors are coupled to PLC-PKC-calcium pathway. EP3 receptors exist in 4 isoforms designated A to D. These EP3 receptors are involved in a wide range of actions from inhibition of cAMP synthesis to increase of intracellular calcium [Arosh J et al, 2004a]. EP2 and EP3 are expressed in bovine CL [Arosh JA et al, 2004b] while EP1 and EP4 are expressed in bovine endometrium [Arosh JA et al, 2003]. Expression of EP2 is highest in the early CL while that of EP3 is higher in late CL [Arosh JA et al, 2004b]. Also EP2 is more expressed more in LLC than SLC. In contrast, EP3 is not expressed in LLC of ovine CL [Fitz TA et al, 1982]. Recent studies have identified EP2 as the major cAMP generating receptor expressed in the CL [Arosh JA et al, 2003]. Intrauterine administration of $\mathrm{PGE}_{2}$ has been shown to have protective effect from spontaneous and/or induced luteolysis in ruminant CL [Pratt BR et al, 1977; Magness RR et al, 1981; Henderson KM et al, 1977; Reynolds LP et al, 1981]. When indomethacin was used to inhibit luteal prostaglandin production, there was a reduced P4 synthesis in the ovine CL [Kim L et al, 2001]. Moreover, a positive association between $\mathrm{PGE}_{2}$ and P4 has been demonstrated during the estrous cycle in cows [Kotwica J et al, 2003].

In ruminants, in contrast to the luteolytic actions of endometrial-derived $\mathrm{PGF}_{2 \alpha}$ during luteolysis, in vitro microdialysis studies have provided evidence of a luteotropic action of $\mathrm{PGF}_{2 \alpha}$ at the early developmental stage of the CL [Miyamoto A et al, 1993]. Results from other in vitro studies with total dispersed luteal cells as well as with pure populations of LLC and SLC have shown that $\mathrm{PGF}_{2 \alpha}$ and several other prostanoids have luteotropic actions in these cells [Hansel W et al, 1991; Choudhary et al, 2005]. PGF $_{2 \alpha}$ via PLC-calcium-PKC intracellular mediators, stimulated P4 synthesis in bovine luteal cells [Hansel W et al, 1987]. There is a close relationship between intracellular calcium and steroidogenesis. It has been suggested that there exists a threshold of intracellular calcium for steroidogenesis [Wegner JA et al, 1991].

\section{Effects of P4}

In vitro studies provided evidence that P4 might have an effect on the functionality of the bovine CL [Skarzynski DJ et al, 2001]. In the bovine CL, P4 
regulates the production of P4 [Skarzynski DJ et al, 1997], OT [Lioustas CH, 1997] and PGs [Pate JL 1996, Pate JL 1988]. It appears that the secretion of $\mathrm{PGF}_{2 \alpha}$ and P4 is interrelated. In mid-late bovine CL, treatment with $\mathrm{PGF}_{2 \alpha}$ inhibits $\mathrm{P} 4$ secretion [Pate JL 1988; Choudhary et al, 2005]. In contrast, $\mathrm{P} 4$ treatment decreases $\mathrm{PGF}_{2 \alpha}$ production in a dose dependent manner [Pate JL 1988]. It may be that the effects of P4 are dependent on the developmental stage of the CL. Findings with P4 antagonist, onapristone, have demonstrated that P4 appears to act in the early CL by stimulating P4, OT, $\mathrm{PGE}_{2}$ and $\mathrm{PGF}_{2 \alpha}$ secretion but inhibits $\mathrm{PGF}_{2 \alpha}$ secretion in the mid-cycle CL [Skarzynski DJ et al, 1999]. Therefore, $\mathrm{P} 4, \mathrm{OT}$ and $\mathrm{PGF}_{2 \alpha}$ are components of a feedback loop that may have both stimulatory and inhibitory roles depending on the stage of luteal development.

P4 has an anti-apoptotic action that protects the CL from premature luteolysis. Rueda [Rueda BR et al, 2000] showed that inhibition of P4 production by aminoglutethimide (P450scc inhibitor) caused apoptosis in cultured bovine luteal cells and this effect was abolished by $\mathrm{P} 4$ supplementation. Also, the effects of P4 on apoptosis in the cultured bovine luteal cells appeared to be mediated by P4 receptor, as RU-486 or onapristone caused luteal cell apoptosis without any effect on luteal P4 secretion [Rueda BR et al, 2000]. In cultured bovine luteal cells, P4 plays a luteotropic role by stimulating the synthesis of LH receptors [Jones LS et al, 1992]. In bovine luteal cells, the antiapoptotc action of P4 is believed to be via inhibition of expression of Fas and caspase-3 mRNA expression [Okuda K et al, 2004].

Rothchild postulated that progesterone stimulates its own secretion, thereby providing positive feedback for a free-running CL [Rothchild I, 1981]. In fact, discovery of $\mathrm{P} 4$ receptor in primate luteal tissue [Hild-Petito S et al, 1988] as well as membrane P4 receptor in mouse luteal cells [Peluso JJ et al, 2005] further strengthen this idea. Progesterone receptor expression is induced in rat granulosal cells by the LH surge [Natraj U et al, 1993] and is dependent on cAMP and granulosal cell differentiation [Clemens JW et al, 1998]. Blockade of the conversion of pregnenolone to progesterone reduces CL mass in monkeys [Duffy DM et al, 1997]. Progesterone receptor antagonists inhibit luteinization in bovine granulosal cells, as indicated by loss of oxytocin gene upregulation [Lioutas $\mathrm{C}$ et al, 1997]. In immortalized porcine granulosal cells, synthetic progestins act in synergy with cAMP to increase progesterone synthesis, while 
progesterone and other progestins upregulate P450scc [Rodway MR et al, 1999]. Progesterone further promotes differentiation and inhibits proliferation of human granulosa-luteal cells in vitro [Chaffkin LM et al, 1993].

\section{Prostaglandin (PG) Metabolic Pathway}

Prostaglandins (PG) are all derivatives of a $\mathrm{C}_{20}$ fatty acid in which carbon atoms 8 to 12 comprise the cyclopentane ring. Arachidonate is the substrate for series $2 \mathrm{PG}$ biosynthesis. Arachidonate is stored in cell membranes esterified to glycerol at $\mathrm{C}_{2}$ of phosphatidylinositol, plasmenylcholine, phosphatidylcholine and other phospholipids. The production of arachidonate metabolites is controlled by the rate of arachidonate release from these phospholipids through three alternative pathways.

1. Phospholipase $\mathrm{A}_{2}\left(\mathrm{PLA}_{2}\right)$ hydrolyzes acyl groups at $\mathrm{C}_{2}$ of phospholipids.

2. Phospholipase C (PLC) specifically hydrolyzes the phosphatidylinositol head group to yield 1, 2-diacylglycerol (DAG), which is phosphorylated by diglycerol kinase to phosphatidic acid, a PLA 2 substrate [Flint APF et al, 1986; Burns PD et al, 1997].

3. DAG also may be hydrolyzed directly by diacylglycerol lipase.

There are two pathways of arachidonate metabolism, one that involves the formation of PGs and the other in the formation of Leukotrienes and Hydroperoxyeicosatetraenoic acids (HPETE). The first step of PG biosynthesis is catalyzed by $\mathrm{PGH}_{2}$ synthase $\left(\mathrm{PGH}_{2}\right.$ synthase; PG endoperoxide synthase). This heme-containing enzyme has two catalytic activities; (1) a cyclooxygenase activity, that catalyzes the addition of two molecules of oxygen to arachidonic acid to form $\mathrm{PGG}_{2}$ and (2) a peroxidase activity that converts $\mathrm{PGG}_{2}$ to $\mathrm{PGH}_{2}$ by adding an $\mathrm{OH}$ group. $\mathrm{PGH}_{2}$ is the immediate precursor of all series 2 prostaglandins, prostacyclins and thromboxanes. The fate of $\mathrm{PGH}_{2}$ depends on the relative activities of enzymes catalyzing specific interconversion of $\mathrm{PGH}_{2}$ to different PGs ( $\mathrm{PGE}_{2}, \mathrm{PGF}_{2 \alpha}, \mathrm{PGD}_{2}, \mathrm{PGI}_{2}$ and thromboxanes). The presence and activity of these enzymes are dependent on tissue type and the physiological state of that tissue [Gibson $\mathrm{KH}, 1982]$. 


\section{Phospholipase $A_{2}\left(P_{2} A_{2}\right)$}

There are two families of PLA 2 , a calcium dependent cytosolic PLA $2\left(\mathrm{CPLA}_{2}\right)$, which is produced in an inactive precursor form and a calcium independent membrane bound $\mathrm{PLA}_{2}\left(\mathrm{iPLA}_{2}\right)$. Each family of PLA 2 exists in a number of isoforms transcribed from separate genes located on the same chromosome [Murakami M et al, 1998]. In mammals, there are at least four $\mathrm{cPLA}_{2}$ isoforms: $\alpha, \beta, \gamma$ and $\delta$ (Six DA et al, 2000; Hirabayashi T et al, 2004]. Activation of cPLA 2 requires calcium binding at the $\mathrm{N}$-terminal $\mathrm{C} 2$ domain and phosphorylation on serine residues. Calcium binding causes redistribution of $\mathrm{cPLA}_{2}$, particularly to the nuclear envelope and ER, where cPLA 2 hydrolyzes arachidonic acid from membrane phospholipids [Gijon MA et al, 1999]. Serine phosphorylation is mediated by mitogen-activated protein kinases (MAPKs) [Lin LL et al, 1993], calcium / calmodulin dependent protein kinase II (CAMK II) [Mubarack M. Muthalif et al, 2001] and MAPK interacting kinase Mnk 1 [Ying Hefner et al, 2000]. In some cell types, PKC activation and/or inhibition of certain phosphatases with okadaic acid contributes to cPLA $_{2}$ activation [Gijon MA et al, 1999].

\section{Conversion of Arachidonic acid to $\mathrm{PGH}_{2}$}

Conversion of arachidonic acid to $\mathrm{PGH}_{2}$ is catalyzed by $\mathrm{PG}$ endoperoxidase $\mathrm{G} / \mathrm{H}$ synthase (PGHS or Cox) and this step commits arachidonic acid to the PG biosynthesis. This process involves two enzymatic steps; first, conversion of arachidonic acid to $\mathrm{PGG}_{2}$ involving cyclooxygenase $(\mathrm{Cox})$ and second, a peroxidase step that reduces $\mathrm{PGG}_{2}$ to $\mathrm{PGH}_{2}$. In non-inflammatory $\mathrm{PG}$ production, $\mathrm{Cox}$ is the rate limiting enzyme of $\mathrm{PG}$ synthesis. There are two isoforms of Cox; Cox-1 and Cox-2 [Lysz TW et al, 1988]. Cox1 and Cox-2 utilize different pools of arachidonic acid [Wiltbank MC et al, 2003]. Cox-1 is constitutively expressed in many tissues and is involved in homeostatic regulation of arterial blood pressure [Jun SS et al, 1999] and gastric epithelial function [Cohn SM et al, 1997]. In contrast, Cox-2 is inducible and is expressed in many tissues during acute responses such as inflammation [Simon LS et al, 1999]. Moreover, these isoforms differ in their sub-cellular localization. Immunohistological studies [Morita I et al, 1995] have revealed that Cox-2 is present mainly in the nuclear membrane while Cox-1 is localized 
equally to the ER and nuclear membrane. In vivo and in vitro treatment of the CL with PGF ${ }_{2 \alpha}$ results in increased Cox-2 expression during luteal regression [Tsai SJ et al, 1997; Diaz FJ et al, 2000]. Recently a third isoform of Cox, Cox-3, has been isolated and characterized [Willoughby DA et al, 2000]. Cox-3 is derived from the Cox-1 gene, but retains intron 1 in the mRNA. The exact physiological function of Cox-3 is yet to be determined but it is postulated to be the target of acetaminophen action [Chandrasekharan NV et al, 2002].

\section{Conversion of $\mathrm{PGH}_{2}$ to $\mathrm{PGE}_{2}$}

In cattle, conversion of $\mathrm{PGH}_{2}$ to $\mathrm{PGE}_{2}$ occurs via PGE synthases (PGES). Currently three forms of PGES [Parent $J$ et al, 2005] have been identified. Microsomal PGES 1(MPGES1) [Jakobsson PJ et al, 1999], also known as Prostaglandin E Synthase (PGTES) [Filion F et al, 2001], is membrane bound [Murakami $\mathrm{M}$ et al, 2000], inducible and associated with Cox-2 induction [Arosh JA et al, 2002]. Cytosolic PGES (CPGES), known as cytosolic PGTES (PGTES3) is coupled to Cox-1 [Tanioka T et al, 2000]. The third form of PGES is microsomal PGES2 (MPGES2), also known as prostaglandin E synthase 2 (PGTES2), which has been recently purified from the bovine heart [Watanabe $\mathrm{K}$ et al, 1999]. This PGES is associated with both forms of Cox, with slight preference for Cox-2 [Murakami M et al, 2003]. Immunohistological studies reveal that MPGES1, MPGES2 and CPGES are expressed in high amounts in the luminal and glandular epithelial cells of the bovine endometrium, as compared to the stromal cells. These isoforms are expressed in many other bovine tissues such as ovary, kidney and lung [Parent $\mathrm{J}$ et al, 2005]. Moreover, in the bovine endometrium, high expression of Cox-2 [Arosh JA et al, 2002], MPGES1 [Parent J et al, 2005] and EP2 [Arosh JA et al, 2003] on days 10-18 of the estrous cycle closely follows production of $\mathrm{PGE}_{2}$ [Miyamoto $\mathrm{Y}$ et al, 2000]. Authors of recent in vitro studies have suggested that CPGES and MPGES2 are involved in basal $\mathrm{PGE}_{2}$ production while MPGES1 in association with Cox-2 is the main PGES responsible for increased production of $\mathrm{PGE}_{2}$ in endometrial cells [Parent $\mathrm{J}$ et al, 2005]. 


\section{Formation of $P G F_{2 \alpha}$}

Synthesis of $\mathrm{PGF}_{2 \alpha}$ can take place from $\mathrm{PGE}_{2}, \mathrm{PGH}_{2}$ and $\mathrm{PGD}_{2}$. Prostaglandin $\mathrm{E}_{2}-9$ ketoreductase is NADPH -dependent enzyme that reduces the ketone on the $9^{\text {th }}$ carbon of $\mathrm{PGE}_{2}$, thus converting $\mathrm{PGE}_{2}$ to $\mathrm{PGF}_{2 \alpha}$. Prostaglandin $\mathrm{E}_{2}-9$-ketoreductase is present in the CL [Albarracin CT et al, 1994; Beaver CJ et al, 1992; Wintergalen N et al, 1995] and uterus [Asselin E et al, 2000] of a number of species. Prostaglandin $E_{2}-9$-ketoreductase is a member of aldoketo reductase superfamily. In rabbit CL, a pure preparation of $20 \alpha-$ hydeoxysteroid dehydrogenase enzyme was found to contain prostaglandin $\mathrm{E}_{2}-9$ ketoreductase activity [Wintergalen N et al, 1995]. Moreover the mRNA sequences of these two enzymes are identical, so it has been suggested that the enzyme that inactivates P4 also may inter-convert PGs within the CL [Asselin E et al, 2000]. In in vitro studies, addition of $\mathrm{PGE}_{2}$ to luteal tissue resulted in the formation of $\mathrm{PGF}_{2 \alpha}$, but the amount of conversion depended on the species. For example, the human CL converted a large amount of $\mathrm{PGE}_{2}$ to $\mathrm{PGF}_{2 \alpha}$, while the conversion is low in the porcine CL [Watson $\mathrm{J}$ et al, 1979].

The conversion of $\mathrm{PGH}_{2}$ to $\mathrm{PGF}_{2 \alpha}$ is catalyzed by PGF synthase (PGFS). There are a number of PGFS isoforms that may vary among species and tissues. The first three isoforms of PGFS isolated in the cow are: lung type prostaglandin F synthase (PGFS1) [Watanabe K et al, 1985], lung type PGFS found in liver (PGFS2) [Kuchinke W et al, 1992], and liver type PGFS, also called dihydrodiol dehydrogenase 3 (DDBX) [Suzuki T et al, 1999; Chen LY et al, 1992]. DDBX exists in 4 isoforms in human beings and 3 isoforms in the cow and has $3 \alpha$-HSD activity. Only the DDBX3 isoform found in the liver has been characterized in the cow [Suzuki T et al, 1999]. The PGFS1 and PGFS2 enzymes are $99 \%$ identical, whereas DDBX is $86 \%$ identical to each of them. Three other PGFS have been isolated and characterized from human tissue [Suzuki-Yamamoto $\mathrm{T}$ et al, 1999], sheep tissue [Wu WX et al, 2001] and Trypanosoma brucei [Kubata BK et al, 2000]. All of these enzymes belong to the aldoketoreductase family [Jez JM et al, 1997]. The enzyme from Trypanosoma belongs to the AKR5A subfamily, whereas the others belong to the AKR1C family, which also is associated with hydroxysteroid dehydrogenases. Except for the Trypanosoma enzyme, all the other forms of PGFS possess $\mathrm{PGD}_{2}$ 11-ketoreductase activity, thus giving them the ability to convert $\mathrm{PGD}_{2}$ 
into 9,11 $\mathrm{PGF}_{2 \alpha}$, an isomer of $\mathrm{PGF}_{2 \alpha}$ [Watanabe $\mathrm{K}$ et al, 1986]. Recently it has been reported that bovine endometrium does not express any members of the AKR1C family (to which most of the PGFS belongs). Instead, aldoketoreduactase 1B5 (AKR1B5), which possesses $20 \alpha$-HSD activity, is the main PGFS responsible for the production of $\mathrm{PGF}_{2 \alpha}$ in the bovine endometrium [Madore E et al, 2003]. Studying pregnant and non-pregnant ewes, Costine [Costine B, 2004] has proposed that the regulation of PG synthesis likely occurs via transcriptional control of PGE and PGF synthase rather than that of COX-2. The same author has demonstrated apparent species differences with respect to the type of PGF synthase present in the CL. In the bovine CL, AKR1B5 and not PGF synthase 1 is the main PGF synthase. In contrast, in the ovine CL, both PGF synthase 1 and AKR1B5 were present.

\section{Catabolism of PGs}

Catabolism of PG occurs in blood and is removed into the blood plasma filtrate in the kidney followed by excretion through the urine. Prostaglandin dehydrogenase (PGDH), an oxidoreductase enzyme, catalyses the oxidation of the $\mathrm{OH}$ group on carbon 15 of $\mathrm{PGF}_{2 \alpha}$ and $\mathrm{PGE}_{2}$ to yield 15-keto $\mathrm{PGF}_{2 \alpha}$ and 15-keto $\mathrm{PGE}_{2}$. There are two types of $\mathrm{PGDH}$, one that transfers hydrogen to $\mathrm{NADP}^{+}$and another that transfers hydrogen to $\mathrm{NAD}^{+}$[Lee SC et al, 1975]. There are greater amounts of $\mathrm{NADP}^{+}$than $\mathrm{NAD}^{+}$-dependent PGDH in the lung of ruminants and placenta of many species [Challis JR et al, 2002]. Recently $\mathrm{NAD}^{+}$-dependent PDGH has been identified in the ovine CL and it has been hypothesized that this is the rate limiting enzyme in PG catabolism [Silva PJ et al, 2000].

A second step in PG catabolism involves the conversion of 15-keto PGs to 13,14dihydro-15-keto PGs (PGFM and PGEM). Fifteen-oxoPG 13- reductase (OXO-PGR) catalyzes this reaction by reducing the 13,14 double bond (by $\Delta 13$ reductase) resulting in the formation of PGFM or PGEM [Hansen HS, 1982]. The hydrolysis of other PGs to their respective keto acids is spontaneous except for $\mathrm{PGD}_{2}$, which has its own PGDH enzyme. 


\section{Regulation of $\mathrm{PGF}_{2 \alpha}$ production}

\section{Uterine PGF PG $_{2 \alpha}$ synthesis}

In many species, the endometrium is the site for uterine $\mathrm{PGF}_{2 \alpha}$ synthesis. In ruminants, OT, $\mathrm{P} 4$ and $\mathrm{E} 2$ regulate uterine secretion of $\mathrm{PGF}_{2 \alpha}$. Estrogen increases uterine $\mathrm{PGF}_{2 \alpha}$ production by stimulating the activity of metabolic enzymes involved in PG biosynthesis [Bonney RC et al, 1987; Dey SK et al, 1982; Ham EA et al, 1975; Wlodawer O et al, 1976]. Furthermore, in several species, prior exposure to $\mathrm{P} 4$ enhances E2-stimulated production of $\mathrm{PGF}_{2 \alpha}$ [Barcikowski B et al, 1974; Castracane VD et al, 1975; Ford SP et al, 1975; Lewis PE et al, 1977]. Several researchers have concluded that $\mathrm{P} 4$ action is required to prime the endometrium for subsequent $\mathrm{PGF}_{2 \alpha}$ production [Garrett JE et al, 1988; Morgan GL et al, 1993; Vallet JL et al, 1990]. P4 enhances PGF $_{2 \alpha}$ synthesis by increasing the concentration and activity of endometrial PG synthases [Eggleston DL et al, 1990; Raw RE et al, 1988]. Also, the timely down regulation of P4 receptors by $\mathrm{P} 4$ is an important component in timing the onset of luteolysis [Ottobre JS et al, 1980; Woody CO et al, 1967].

From in vivo and in vitro studies, it has become apparent that E2 and P4 control endometrial $\mathrm{PGF}_{2 \alpha}$ production by regulating the concentration of endometrial OT receptors [Armstrong DT et al, 1959; McCracken JA, 1972; McCracken JA, 1980; Sharma RC et al, 1974; Soloff MS, 1975]. During the luteal phase, E2 enhances the formation of endometrial OT receptors. In contrast, P4 reduces the concentration of endometrial OT receptors by blocking the action of E2 [Grazzini E et al, 1998]. In vitro studies demonstrate that $\mathrm{P} 4$ also has a direct non-genomic inhibitory effect on uterine OT receptors [Rueda BR et al, 2000; MT Rae et al, 1998]. Thus, the uterus becomes refractory to OT during the luteal phase in terms of $\mathrm{PGF}_{2 \alpha}$ secretion [McCracken JA et al, 1999]. However, P4 eventually down regulates its own receptor towards the end of the luteal phase [Milligrom E et al, 1973; Vu Hai MT et al, 1977; Clarke CL, 1990]. This restores the action of $\mathrm{E} 2$ that stimulates the hypothalamus [McCracken JA et al, 1995] to secrete high frequency bursts of low levels of OT. At the same time upregulating endometrial OT receptors in the uterus are upregulated [McCracken JA et al, 1999]. McCracken [McCracken JA et al, 1999] proposed a double positive feedback loop 
between the uterus and the CL as a possible mechanism of luteal regression. Low levels of $\mathrm{PGF}_{2 \alpha}$ (subluteolytic) get released from the uterus due to the interaction of posterior pituitary OT and endometrium OT receptors [McCracken JA et al, 1995; McCracken JA et al, 1999]. In the CL, the uterine subluteolytic $\mathrm{PGF}_{2 \alpha}$ initiates luteal OT release via high sensitivity $\mathrm{PGF}_{2 \alpha}$ receptors (HFPR) [Wiltbank C et al, 1995]. Studies with PG treatment and injection of the $\mathrm{PGF}_{2 \alpha}$ analog-cloprostenol in cow and sheep showed elevated levels of OT release from the CL [Flint APF et al, 1982]. In sheep and cow [Ivell R, 1985; Ivell $\mathrm{R}$ et al, 1984; Ivell R et al, 1990], OT is expressed fully in the developing CL shortly after ovulation. The site of OT synthesis in the CL was shown to be the LLC in cows [Fehr S et al, 1987; Fields MJ et al, 1986; Fields PA et al, 1983]. Moreover, OT and neurophysin have been identified in small electron-dense granules present in the LLC [Rice GE, 1988; Theodosis DT et al, 1986]. These oxytocin-containing granules are believed to be released by exocytosis. Luteal OT amplifies the release of endometrial $\mathrm{PGF}_{2 \alpha}$ secretion. The latter then stimulates the low sensitivity $\mathrm{PGF}_{2 \alpha}$ receptors (LFPR) resulting in the release of additional luteal OT thereby initiating luteal $\mathrm{PGF}_{2 \alpha}$ production [McCracken JA et al, 1999]. Thus, the uterus appears to act as a transducer that converts neural signals (OT pulse generator) into uterine $\mathrm{PGF}_{2 \alpha}$ pulses that are required for luteolysis. In cow and other ruminants, luteal OT appears to act as a supplemental source of OT that amplifies these neural signals and hence increases the magnitude of the luteolytic signal via intraluteal $\mathrm{PGF}_{2 \alpha}$ synthesis [McCracken JA et al, 1999].The interval between subsequent uterine $\mathrm{PGF}_{2 \alpha}$ pulses depends on two factors: 1) the high frequency burst of OT from the posterior pituitary that is regulated by the hypothalamus and 2) recovery of the endometrial OT receptors that may be down regulated atleast at the early stages of luteal regression.

OT is a nanopeptide hormone synthesized as part of a high-molecular weight precursor in the hypothalamic magnocellular neurons and is packaged into secretory granules. These OT secretory granules reach the neurohypophysis via axonal transport. In the neurohypophysis, OT precursor is cleaved into mature OT and released into the blood stream [Lincoln DW, 1984]. It has been proposed that E2 and P4 regulate the pulsatile release of OT. Both E2 and P4 receptors are present in the hypothalamus in many species [Blaustein JD et al, 1995; Lehman MN et al, 1993] and in rats P4 has been demonstrated 
to down regulate its own receptor in the hypothalamus [Moguilewsky $M$ et al, 1979]. In rat, co-localization of the beta-form of E2 receptor with the OT neurons significantly increased the chance of direct action of E2 on OT in the hypothalamus [Hrabovszky E et al, 1998]. Gonadal steroids have also been shown to upregulate OT and vasopressin gene expression in the hypothalamus, thus potentially amplifying steroid regulatory effects on the OT pulses [Akaishi T et al, 1985; Amico JA et al 1995; Cadwell JD et al, 1989]. However, the exact mechanism by which these steroids alter the frequency of the central OT pulses is presently unknown.

Presently there is a controversy on whether luteal OT is actually necessary for regression. In both cows and ewes, the concentration of OT is lower in the late than in the mid luteal stage. Lowering OT concentration in the late luteal phase has no effect on the duration of the estrous cycle [Kotwica J et al, 1993]. Furthermore, in cows, in vivo microdialysis study demonstrated lack of detectable OT secretion during spontaneous luteolysis [Blair RM et al, 1997; Shaw DW et al, 2000]. Based on these observations, it is hypothesized that luteal OT may not be essential for luteal regression. In fact, Bacon and McCracken proposed that in sheep, luteal OT might play an advantageous role for the establishment of pregnancy [Bacon C et al, 2004].

\section{Intraluteal $\mathbf{P G F}_{2 \alpha}$ Production}

In luteal cells, an autoamplification loop exists involving $\mathrm{PGF}_{2 \alpha}$-induced intraluteal $\mathrm{PGF}_{2 \alpha}$ production. Intraluteal $\mathrm{PGF}_{2 \alpha}$ production involves interaction between multiple signaling pathways. Treatment of luteal cells by $\mathrm{PGF}_{2 \alpha}$ increases $\left[\mathrm{Ca}^{2+}\right]_{\mathrm{i}}$ that results in $\mathrm{cPLA}_{2}$ activation [Wiltbank $\mathrm{MC}$ et al, 1989a]. In addition, $\mathrm{PGF}_{2 \alpha}$ treatment activates MAP kinase [Chen DB et al, 1998] and PKC [Wiltbank MC et al, 1989b], both of which activate $\mathrm{cPLA}_{2}$, contributing to intraluteal $\mathrm{PGF}_{2 \alpha}$ production $[\mathrm{Wu} \mathrm{XM}$ et al, 1990]. Studies conducted with in vivo administration of $\mathrm{PGF}_{2 \alpha}$ demonstrate that luteal changes in $\mathrm{cPLA}_{2}$ may be mediated by protein activation rather than transcriptional regulation [Tsai SJ et al, 2001; Wiltbank MC et al, 2003]. Therefore, treatment of CL with $\mathrm{PGF}_{2 \alpha}$ is likely to cause $\mathrm{cPLA}_{2}$ activation through a number of pathways allowing arachadonic acid release. Furthermore, in the CL, in vivo treatment with $\mathrm{PGF}_{2 \alpha}$ greatly 
increases expression of Cox-2 mRNA and protein [Tsai SJ et al, 1997; Diaz FJ et al, 2000]. Thus, $P F_{2 \alpha}$ induces both the key rate limiting steps of $P G$ biosynthesis.

In bovine and ovine $\mathrm{CL}$, the molecular mechanisms involved in $\mathrm{PGF}_{2 \alpha}$ induction of Cox-2 have been analyzed. In bovine $\mathrm{CL}$, single in vivo treatment with $\mathrm{PGF}_{2 \alpha}$ induces Cox-2 expression only in the mid-late luteal stage (days 10-12). In the early CL, even though $\mathrm{PGF}_{2 \alpha}$ activates FP receptors, it fails to induce Cox-2 gene expression [Tsai SJ et al, 1998; Tsa SJ et al, 2001a]. Treatment of in vitro luteinized bovine granulosal cells with $\mathrm{PGF}_{2 \alpha}$ induced Cox-2 expression only after 7 days of luteinization, similar to the timing observed in the in vivo experiment [Tsai SJ et al, 2001b]. Using the same model system, the authors demonstrated that in early stages of luteinization Cox-2 expression is induced by cAMP-PKA, while at the latter luteal stage (similar to the timing observed in the in vivo experiment) PKC induces Cox-2 expression [Wu YL et al, 2002]. The authors identified an E-box element in the Cox-2 promoter region that was a critical regulatory element for Cox-2 gene induction. Furthermore, both PKA and PKC act on the same E box element in a luteal stage dependent manner to induce Cox-2 gene expression [Wu YL et al, 2002]. Similar results were also obtained from ovine CL. Moreover, in the ovine $\mathrm{CL}, \mathrm{PGF}_{2 \alpha}$ acts via PKC $\alpha$ and $\beta$ on the E-box DNA element to induce Cox-2 gene transcription [Wu YL et al, 2001].

The physiological role of intraluteal $\mathrm{PGF}_{2 \alpha}$ production has not yet been clearly defined. However, in species with uterine dependent regression of the CL, it is clear that the luteolytic factor secreted by the uterus is $\mathrm{PGF}_{2 \alpha}$. It is believed that the small amounts of uterine $\mathrm{PGF}_{2 \alpha}$ dramatically amplify intraluteal $\mathrm{PGF}_{2 \alpha}$ production leading to luteal regression. It has been proposed that uterine $\mathrm{PGF}_{2 \alpha}$ may initiate the inhibition of $\mathrm{P} 4$ production that accompanies luteal regression, while the increase in intraluteal $\mathrm{PGF}_{2 \alpha}$ production may be critical for the structural demise of the CL [Griffeth RJ et al, 2002].

\section{Prostaglandin Transport}

In most mammalian species, transport of endometrial PGs from the uterine to the ovarian compartment occurs via the vascular pathway [McCracken JA et al, 1999]. In ruminants, the ovarian artery is close to the surface of the utero-ovarian vein and 
traverses the vein in an extremely tortuous manner to form an unique structure called the utero-ovarian plexus (UOP) before entering the hilus of the ovary [McCracken JA et al, 1999]. The UOP has long been identified as the primary site of PG transfer and its anatomical and physiological significance has been well established [Ginther OJ, 1981]. Prostaglandins diffuse from the utero-ovarian vein to the ovarian artery and reach the ovary directly without passing through the systemic circulation. Infusion experiments with radiolabeled $\mathrm{PGF}_{2 \alpha}$ confirmed the existence of the countercurrent transfer process in the utero-ovarian vascular pedicle [McCracken JA et al, 1999]. Bonnin et al [Bonnin P, 1989] demonstrated that $\mathrm{PGF}_{2 \alpha}$ is transported to the ovaries by a rapid systemic route and a slower buffer mechanism involving local diffusing in contrast to the counter current system. Moreover, absorption of $\mathrm{PGF}_{2 \alpha}$ from uterine lumen to venous blood is low on the side of uterine horn with active CL [Koziorowski M et al, 1989]. Koziorowski et al [Koziorowski $\mathrm{M}$ et al, 1989] proposed that this effect was due to $\mathrm{E}_{2}: \mathrm{P}_{4}$ ratio on vascular constriction in area of uterine vasculature.

Earlier the mechanism of PG transport across the cell membrane has been proposed to range from simple diffusion to passive transport, active transport and counter current exchange [McCracken JA et al, 1999; Schuster VL, 2002; Schuster VL, 1998]. However, PGs predominate as charged anions and diffuse poorly across cell membranes despite their lipid nature [Schuster VL, 2002; Schuster VL, 1998]. Even though anions (PGs) cross the plasma membrane by simple diffusion, it has been demonstrated that the estimated flow rate is too low to maintain a biological function [Lehninger AL, 2000]. Recently, PG transporter (PGT) has been identified in rat kidney [Kanai $\mathrm{N}$ et al, 1995], human liver [Lu R et al, 1996], mouse lung [Pucci ML et al, 1999] as well as in bovine uterus [Banu SK et al, 2003; Banu SK et al, 2005] and ovary [Arosh JA et al, 2004b]. Prostaglandin transporter belongs to the superfamily of 12 transmembrane organic aniontransporting polypeptides (OATPs) [Schuster VL, 2002; Schuster VL, 1998]. Bovine PGT (bPGT) exhibits a high percentage of homology with its human, mouse and rat counterparts [Banu SK et al, 2003]. The bPGT has 12 hydrophobic transmembrane domains characteristic of OATP and PGT molecules in other species.

In the bovine endometrium, bPGT facilitates efflux and influx of $\mathrm{PGE}_{2}$ and $\mathrm{PGF}_{2 \alpha}$ with equal affinities in a competitive manner. Furthermore, PGT is highly expressed 
when PG production and action is high. PGT expression closely matches the pattern of expression of PG biosynthetic enzymes and receptors [Banu SK et al, 2003]. In the CL, PGT expression is lower at the early developmental stage of the CL (days 1-6) than in the late, mature and regressing stages [Arosh JA et al, 2004b]. In the bovine CL, PGT is expressed exclusively in LLC [Arosh JA et al, 2004b]. Moreover, throughout bovine pregnancy, PGT gene and protein is expressed in the caruncular, intracaruncular, fetal membranes and the utero-ovarian plexus [Banu SK et al, 2005]. It has been suggested that regulation of bPGT expression and its activity may be one of the many factors causing a shift from luteotropic to luteolytic environment in the mid-late CL [Arosh JA et al, 2004b].

\section{PGF $_{2 \alpha}$ Receptor}

Prostaglandin $F_{2 \alpha}$ acts primarily via transmembrane receptor known as FP receptor (FP) that belongs to the seven-transmembrane-domain receptor superfamily. FP gene has been cloned in many species [Sugimoto Y et al, 1994; Graves PE et al, 199] including the cow [Sakamoto $\mathrm{K}$ et al, 1994] and the exon / intron organization is conserved across species [Hasumoto K et al, 1997; Ezashi T et al, 1996]. The FP gene consists of three exons and two introns with translated regions located in exons 2 and 3 [Ezashi T et al, 1996]. Deletion experiments in mice indicated that the promoter region of FP gene may differ for different tissues [Hasumoto $K$ et al, 1997]. Two potential promoter regions have been identified in the bovine FP gene [Ezashi T et al, 1996]. One of these is a $1.6 \mathrm{~kb}$ region upstream of exon 1 and contains consensus sequences for transcription factors (TF): TRE/AP-1 (TPA-responsive element/activator protein-1), NFIL6 (nuclear factor interleukin 6), Sp1 and GCF (GC binding factor). The second potential promoter is located in intron 1 and contains binding motifs for Sp1, TRE/AP-1, CRE, NF-IL6 and AP-2 (activator protein -2) as well as CAAT and TATA boxes.

There are two isoforms of FP - FPA and FPB [Sakamoto K et al, 2002]. These FP isoforms are formed by alternate splicing from a single FP mRNA [Anderson LE et al, 2001]. The FPB isoform is produced by splicing a putative intron sequence of $3.2 \mathrm{~kb}$ in length that is retained in the FPA isoform [Pierce KL et al, 1997]. Thus, the FPB protein is 45 amino acid shorter in the C-terminal end than the FPA isoform [Pierce $\mathrm{KL}$ et al, 
1997]. Wiltbank et al [Wiltbank MC et al, 1995] were unable to detect differences between the developing (days 2-4) and active bovine CL (days 10-12) in either affinity or concentration for FP. However, the localization of FP is controversial. It has been reported that LLC appear to have more FP than SLC [Sakamoto K et al, 1995], while others have reported the presence of FP in both cell types [Chegini $\mathrm{N}$ et al, 1991]. Mamluk et al [Mamluk R et al, 1998] identified the presence of FP mRNA in long term cultured granulosa and theca cells as well as in LLC, SLC and EC, while Cavicchio et al [Cavicchio VA et al, 2002] failed to detect it. Mamluk et al [Mamluk R et al, 1998] demonstrated that $\mathrm{cAMP}$ and $\mathrm{PGF}_{2 \alpha}$ itself are major regulators of FP. There is a controversy about the expression of FP in EC. Mamluk et al [Mamluk R et al, 1998] reported the expression of FP mRNA in EC. In contrast, Cavicchio et al [Cavicchio VA et al, 2002] failed to detect FP mRNA. Moreover, these authors reported that the EC were unresponsive to $\mathrm{PGF}_{2 \alpha}$. Even though specific binding of $\mathrm{PGF}_{2 \alpha}$ to $\mathrm{EC}$ has not been demonstrated, direct effects of $\mathrm{PGF}_{2 \alpha}$ on EC have been reported [Girsh E et al, 1996b; Choudhary $\mathrm{E}$ et al, 2005]. Binding of $\mathrm{PGF}_{2 \alpha}$ to its receptor activates multiple intracellular signaling cascades, details of which are explained in the next section.

\section{VI. $\quad$ PGF $_{2 \alpha}$ induced Intracellular Signaling}

\section{1a. PLC-Ca ${ }^{2+}$-PKC Pathway}

In bovine luteal cells $\mathrm{PGF}_{2 \alpha}$ on binding to its cognate G-protein coupled receptor, activates the membrane-bound phosphoinositide specific PLC [Wiltbank MC et al, 1991]. Phospholipase C hydrolyses phosphatydylinositol 4,5-bisphosphate, thereby yielding 1,4,5-trisphosphate $\left(\mathrm{IP}_{3}\right)$ and diacylglycerol (DAG). Binding of $\mathrm{IP}_{3}$ to its specific receptor on the endoplasmic reticulum (ER) results in the mobilization of intracellular $\mathrm{Ca}^{2+}$. DAG and $\mathrm{Ca}^{2+}$ together activate a family of serine-threonine kinases called Protein Kinase $\mathrm{C}$ or PKC [Davis JS et al, 1987]. Protein Kinase C is a family of protein kinases that is present in all mammalian species and is involved in a vast array of cellular and physiological functions. Most members of this family depend for their activation on phosphatidylserine (PS), DAG and to different extents on calcium and other lipid secondary messengers. Upon activation by hormones, neurotransmitters, phorbol ester or GFs, PKC undergoes translocation from one intracellular compartment to another. The PKC family contains 11 
isoforms that not only differ in their structures and co-activator requirements, but also in function, cellular and sub-cellular localization [Newton AC, 1997].

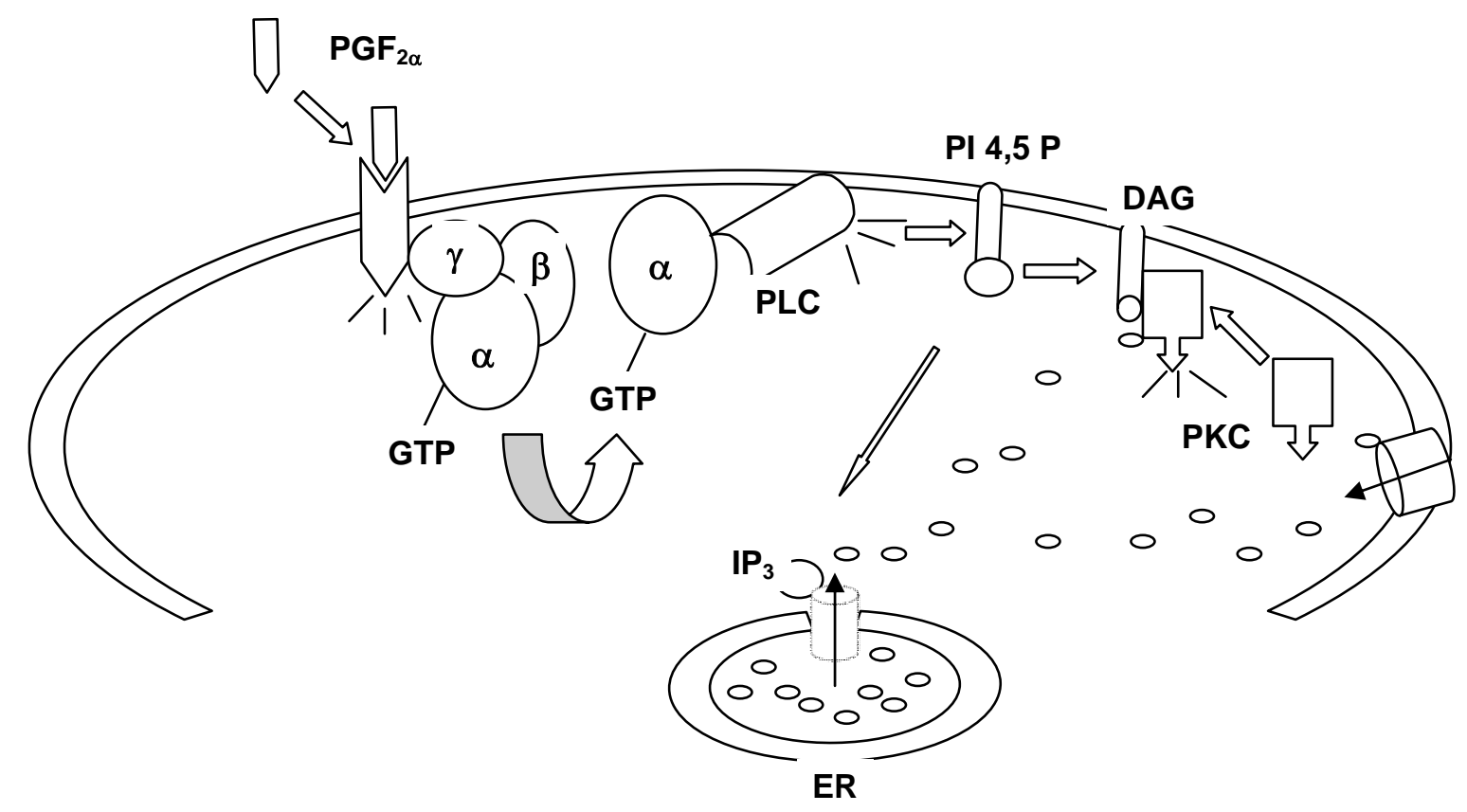

Fig 1. PGF $2 \alpha$ - induced PLC- $\mathrm{Ca}^{2+}-\mathrm{PKC}$ Pathway.

The function of $\mathrm{PGF}_{2 \alpha}$-induced calcium signals and $\mathrm{PKC}$ isozymes in the luteal physiology is discussed in details in chapters $2,3,4,5$ and 6 . Therefore this section reviews the structural and regulatory aspects of different PKC isozymes, an understanding of which is necessary for investigating the role of PKCs in luteal regression.

\section{1b. ERK-MAPK Pathway}

In bovine luteal cell primary cultures, it has been reported that $\mathrm{PGF}_{2 \alpha}$ activates the Raf-1/MEK/ERK signaling cascade, resulting in expression of c-jun and c-fos mRNA [Chen DB et al, 1998; Chen D et al, 2001]. Furthermore, using a PKC inhibitor and PKCdeficient luteal cell model, the investigators demonstrated that the activation of the MAP kinase pathway occurs via PKC phosphorylation of ERK [Chen D et al, 2001]. In other tissues, $\mathrm{PGF}_{2 \alpha}$ can activate ERK-MAP kinase pathway through different mechanisms 
[Ohmichi $\mathrm{M}$ et al, 1997]. Thus it is believed that $\mathrm{PGF}_{2 \alpha}$ may use cell-type-specific signaling pathways to activate ERKs in various tissue and cells. However, which PKC isozyme is involved in ERK activation or which genes are expressed via this pathway is still unknown.

\section{Protein Kinase $\mathrm{C}$}

The discovery of PKC in 1977 by Nishizuka and co-workers was one of the major breakthroughs in the signal transduction field. Protein kinase $\mathrm{C}$ was first defined as a histone kinase from rat brain that could be activated by limited proteolysis. This was followed by the discovery that this new kinase could be activated by phosphotidylserine (PS) and DAG in a calcium-dependent manner as well as by phorbol esters. After 27 years, exhaustive genetic screening has defined a super family of mammalian PKC isozymes that currently is comprised of 11 distinct isozymes. The number of PKC isozymes represents the greatest challenge to the understanding of $\mathrm{PKC}$ function. Protein Kinase $\mathrm{C}$ have a multitude of cellular substrates and are involved in a bewildering array of biological processes [Ron D et al, 1999].

The primary structure of PKC consists of a regulatory and a catalytic unit. The regulatory unit is present in the N-terminal end and contains a pseudosubstrate, a $\mathrm{C} 1$ domain (C1A and C1B) and a C2 domain [Parker PJ et al, 1986]. The C1A and C1B domains bind to DAG or phorbol ester, the $\mathrm{C} 2$ binds anionic lipids and calcium while the pseudosubstrate is involved in the autoinhibitory regulation of PKC. The C-terminal half contains the catalytic portion involving C3 (ATP binding) and C4 (substrate binding / kinase) domains. The PKC family can be divided broadly into 4 subclasses based on their homology and co-activator requirements [Ron D et al, 1999]. Members of the conventional or $\mathrm{cPKC}$ subclass are $\alpha, \beta \mathrm{I}, \beta \mathrm{II}$ and $\gamma$ and contain four homologous domains $(\mathrm{C} 1 \mathrm{~A}$ and $\mathrm{B}, \mathrm{C} 2, \mathrm{C} 3$ and $\mathrm{C} 4)$ interspersed with isozyme unique variable (V) domains. These isozymes require calcium, phosphotidyl serine, DAG or phorbol ester for activation. Members of the novel or $\mathrm{nPKC}$ subclass are $\delta, \varepsilon, \eta$ and $\theta$. This subclass lacks the $\mathrm{C} 2$ domain and is calcium independent for activation. The third PKC subclass is the atypical or aPKC consisting of $\zeta, \imath$ and $\lambda$ that lacks $\mathrm{C} 2$ and one half of the $\mathrm{C} 1$ domain and is insensitive to DAG, phorbol ester and calcium. A related enzyme $\mathrm{PKC} \mu$ or PKC D, 
displays multiple unique features that make it a distant relative of the PKC family and it has been placed in a separate subclass. This isozyme is phopholipid dependent, calcium insensitive and activated by phorbol ester. It contains 2 hydrophobic domains in place of the $\mathrm{C} 1$ domains, and lacks the $\mathrm{C} 2$ domain, but has a putative pleckstrin domain and distinct $\mathrm{C} 3$ and $\mathrm{C} 4$ domains. Recently a large number of proteins have been characterized that have close association with the PKC family and these proteins have been termed as PKC-related kinases [Mellor $\mathrm{H}$ et al, 1998].

Conventional PKC: Calcium \& DAG dependent

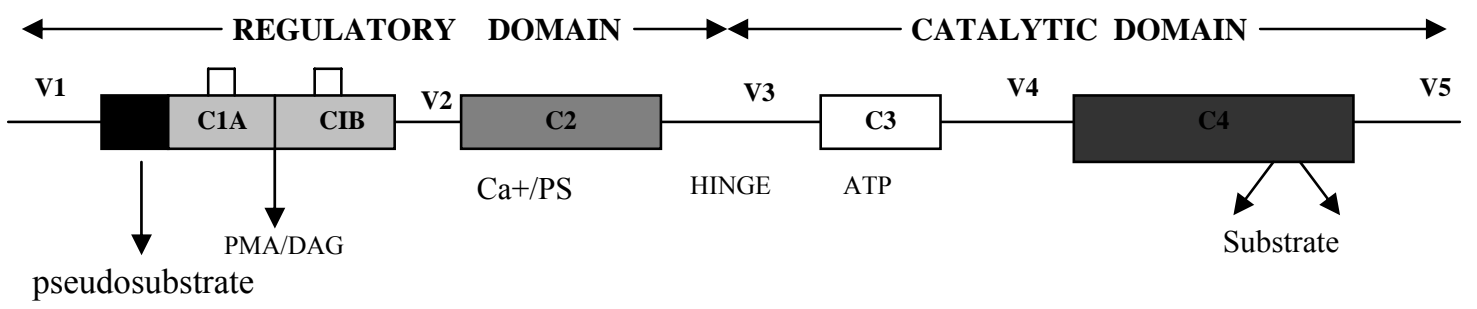

Novel PKC: Calcium independent but DAG dependent

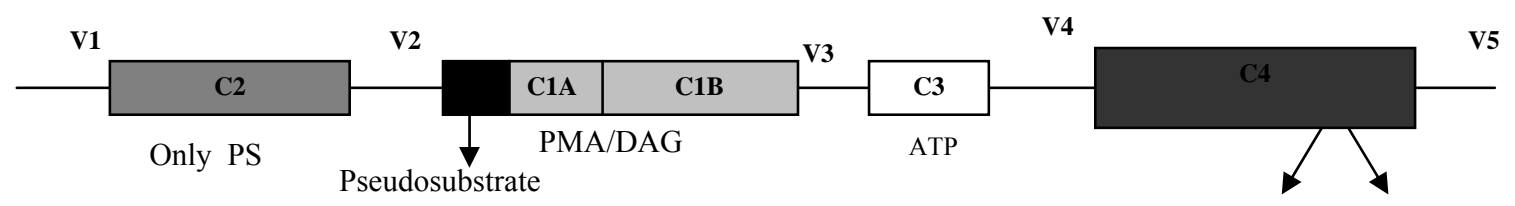

Substrate

Fig 2. Primary structure of members of the conventional and novel PKC subclasses [Adapted from, Principles of molecular regulation. Edited by Conn MP, Means AR. Humana Press, NJ].

Protein kinase $\mathrm{C}$ after synthesis is associated with particulate fractions of the cytoskeletal and plasma membrane components via anchoring proteins. Proteolytic sensitivity experiments have indicated that after synthesis, the C-terminus of PKC occupies the active site. This immature PKC undergoes post-translational modification involving two phosphorylation switches, one at the activation loop and one at the Cterminus [Keranen LM et al, 1995]. The former is phosphorylated by PDK-1 or related kinases. This phosphorylation is required to process catalytically competent PKC; its role 
appears to be correctly aligning residues for catalysis to promote the phosphorylation of the two C-terminal sites. Once the C-terminal ends are phosphorylated, phosphate on the activation loop is no longer required for the catalytic action of the enzyme. At least for cPKC, the C-terminal sites are modified by autophosphorylation. Phosphorylation at these latter two positions locks the enzyme in a catalytically competent conformation and releases the enzyme into the cytosol in a mature but inactive form. In this inactive conformation, the pseudosubstrate binds the active / substrate binding cavity of the kinase domain, thus sterically blocking substrate binding [Newton AC, 1997]. Activation of PKC involves generation of DAG or PMA that binds with the $\mathrm{C} 1$ domain and recruits PKC to the membrane. The translocation of PKC involves the interaction of PKC with isozyme specific anchoring proteins. Protein kinase $\mathrm{C}$ also can be recruited to the membrane by the $\mathrm{C} 2$ domain alone; this interaction requires anionic lipids and for $\mathrm{cPKC}$, calcium. Membrane binding by either domain alone does not provide sufficient energy to release the pseudosubstrate from the active site. This requires the interaction of both $\mathrm{C} 1$ and $\mathrm{C} 2$ domains with the membranes. Once $\mathrm{C} 1$ is bound to the membrane, the enzyme displays a 10-fold increase in affinity for phosphotidylserine (PS) and other relative anionic lipids. The energy supplied by binding of DAG, PS and calcium (for cPKC) helps break electrostatic interactions between the basic pseudosubstrate and acidic substrate binding cavity, resulting in the release of the pseudosubstrate and activation of PKC. Membrane binding with $\mathrm{C} 2$, but not $\mathrm{C} 1$, results in conformational change that exposes the hinge region between the regulatory and catalytic subunits thereby making the catalytic site available for substrate phosphorylation [Newton AC, 1997].

$\mathrm{PKC}$ is a serine / threonine kinase and phosphorylates a number of proteins, including receptors, ion channels, cytoskeletal proteins as well as cell cycle regulatory proteins. One of the best characterized PKC substrates is MARCKS (Myristoylated Alanine Rich C Kinase Substrate) [Newton AC, 1997]. Presence of MARCKS in bovine LLC has been reported and its involvement in exocytosis after phosphorylation by PKC has been demonstrated. However the precise cellular functions and regulation of MARCKS are still unclear [Salli U et al, 2000].

Since the early 1990s, it has become clear that in addition to binding to lipids, $\mathrm{PKC}$ can also interact with proteins via protein-protein interactions [Ron D et al, 1999]. 
These interactions play an important role in the localization, translocation and function of PKC isozymes. Protein kinase $\mathrm{C}$ binding proteins are proteins that bind to PKC directly via a non-substrate domain and may or may not be PKC substrates. There are large numbers of such PKC binding proteins but here only 2 types of such proteins are discussed. Inactive PKC remains attached to the cytoskeletal or membrane via anchoring proteins called receptors for inactive isozymes (RICKS) or A kinase anchoring proteins (AKAPS) [Mochly-Rosen D, 1995]. Similarly, there are anchoring proteins for activated PKC isozymes known as receptors for activated C-kinases (RACKS). Different types of RACKS are PKC isozyme specific. The PKC-RACK interaction is mediated, at least in parts by the $\mathrm{C} 2$ region in cPKCs and the $\mathrm{V}$ region in $\mathrm{nPKCs}$. Two RACKS have been identified: RACK1 specifically binds to PKC $\beta$ II via the V5 domain and to other cPKCs via the C2 domain. In contrast, RACK2 (also called $\beta$ '-COP) specifically interacts with $\mathrm{PKC} \varepsilon$ via the V1 domain that has some homology to the $\mathrm{C} 2$ domain of cPKCs. RACKS contain WD-40 repeats, a motif known to mediate protein-protein interactions. RACKS are known to be involved in translocation of activated PKCs from the cytosol to the membrane [Mochly-Rosen D et al, 1998].

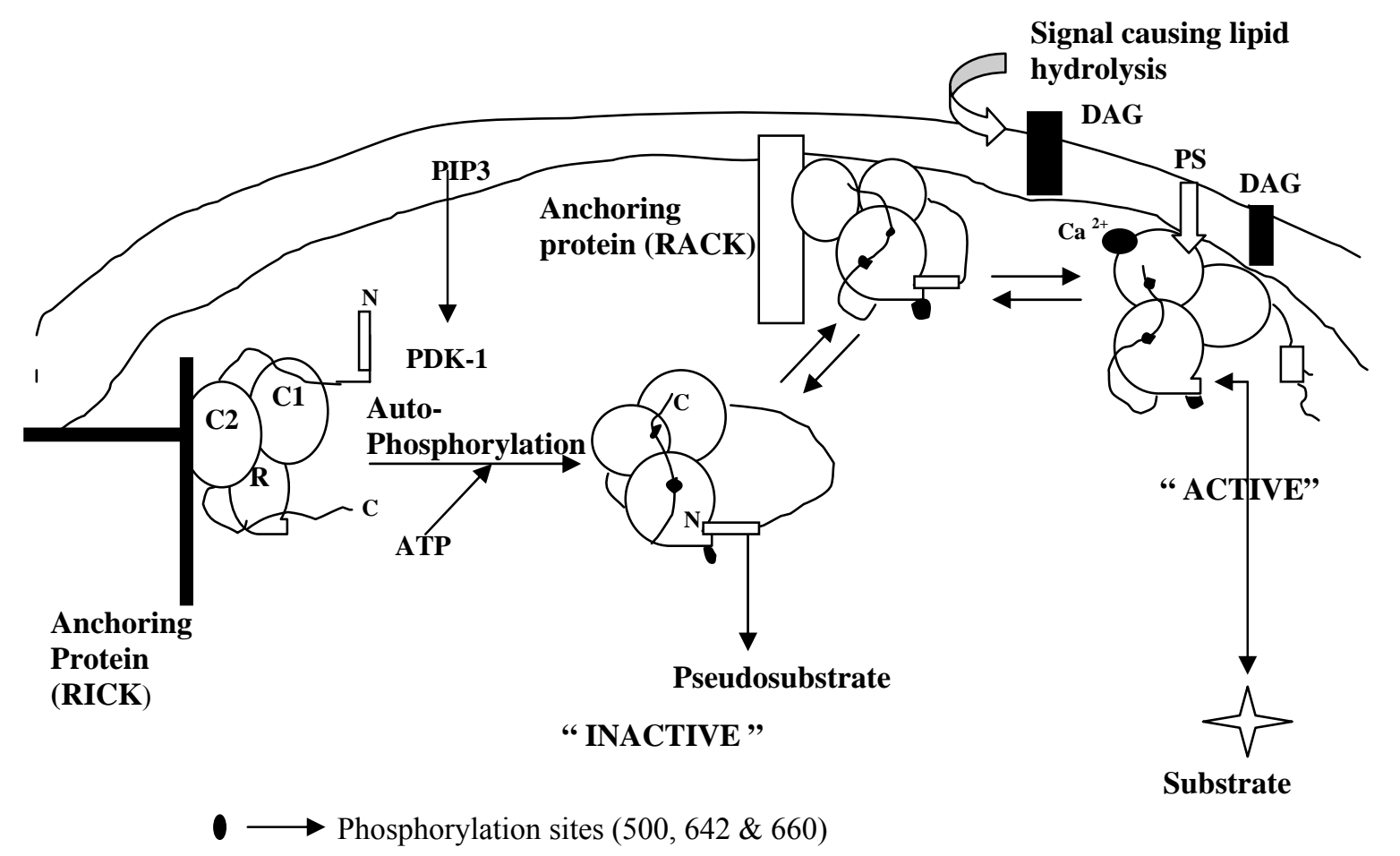

Fig 3. Intra-cellular Mechanism of PKC activation [Adopted from, Newton AC, 1997]. 


\section{Endothelin System}

Endothelin (ET) was first identified as a potent vasoconstrictor in cardiovascular homeostasis [Yanagisawa M et al, 1988], embryonic development [Kedzierski RM et al, 2001] and angiogenesis [Schmitz-Sapanke S et al, 2000]. In recent years, endothelin has emerged as a key modulator in reproductive organs involved in the regulation of steroidogenesis in follicles [Flores JA et al, 1992; Flores JA, 2000] and CL [Girsh E et al, 1996a; Hinckley ST et al, 2001, Wright M et al, 2003, Choudhary et al, 2004, Schams D et al, 2004, Meidan R et al, 1999]. Endothelin exists in different isoforms (ET-1, ET-2, and ET-3) encoded by three separate genes [Luscher TF et al, 2000]. Endothelin-1 (ET-1) is synthesized as a 212-amino acid precursor, prepro ET-1 (ppET-1), which is proteolytically cleaved into a 38-amino acid long big ET-1 by furin or furin-like enzymes in the trans-golgi network. Big ET-1 is further converted into active ET-1 (21 amino acid) by metalloproteinases, specifically endothelin converting enzymes (ECE) [Luscher TF et al, 2000; Okuda K et al, 1990]. There are 4 isoforms of ECE [Muller L et al, 2003] each of which specifically cleaves its corresponding big ET. Endothelin converting enzymes 1 and 2 are transcribed from two separate genes, while ECE-3 and ECE-4 have not yet been cloned. ECE-1 is a membrane-bound protein that belongs to the zinc-binding metalloendopeptidases [Yanagisawa M, 1995; Opgenorth T et at, 1992]. Endothelin converting enzyme -1 has 4 known isoforms formed by transcription initiation at alternative promoters [Muller L et al, 2003]. All these isoforms are identical except at their N-terminal ends that regulate subcellular localization. Endothelin converting enzymes $1 \mathrm{a}$ and $1 \mathrm{c}$ are expressed on the plasma membrane and are involved in the conversion of big ET into active ET-1. In contrast, ECE-1b and ECE-1d are localized to endosomes and regulate the availability of ECE-1a on the plasma membrane via heterodimerization with the latter [Muller L et al, 2003]. It has been demonstrated that endothelial cells in the CL express ECE-1a and ECE-1b, while the luteal steroidogenic cells exclusively expresses ECE-1b [Meidan R et al, 2002]. Meidan et al [Meidan R et al, 2002] proposed a model according to which the endothelial cells expressing ppET-1 along with the two ECE-1 isoforms are capable of secreting both the big ET-1 as well as the mature ET-1. In contrast, the luteal steroidogenic cells expressing only ECE-1b, but no ppET-1 are dependent on extracellular big ET-1. 
Despite the many reports showing that ECE-1 isoforms are able to convert big ET-1 to the mature ET-1 peptide, it is still unclear whether ECE-1 plays a physiological role in big ET-1 processing. Some studies indicate that ECE might not be the rate limiting factor in ET-1 production. In bovine pulmonary smooth muscle cells, ablation of the ECE gene by antisense oligonucleotides did not have any effect on either basal or TNF $\alpha$ stimulated ET-1 release.The authors proposed that in bovine pulmonary smooth muscle cells, an endopeptidase distinct from ECE-1 may be responsible for processing big ET-1 [Barker S et al, 2001]. In bovine CL, although the ratio of ET-1 / bigET-1 is higher in the late than the early-mid luteal stage, ECE-1 is constituitively expressed until the late luteal stage, when the gene actually appears to be downregulated [Wright $\mathrm{M}$ et al, 2003; Choudhary E et al, 2004]. Furthermore, ECE activity remains unchanged throughout the estrous cycle [Choudhary E et al, 2004]. These studies indicate that the regulation of ET1 production is a complex process that may involve other factors.

Endothelin acts via the 7-transmembrane-G-protein coupled receptor family [Arai $\mathrm{H}$ et al, 1990] which exist in two subtypes, ETA (for aorta) and ETB (for bronchus) transcribed from two separate genes [Aramori I et al, 1992]. ETA is highly specific for ET-1 (about 100 times more than ET-3), while all three (ET-1, ET-2 and ET-3) binds to ETB with equipotent affinity [Arai $\mathrm{H}$ et al, 1990; Aramori I et al, 1992]. Characterization and regulation of ETA [Meidan R et al, 2002; Meidan R et al, 1999; Choudhary E et al, 2004] in bovine luteal cells have been investigated extensively (discussed in the next section), while the role of ETB is still unclear. The intracellular mediators of ET-1 in the $\mathrm{CL}$ are unknown. However, several studies indicate that ET-1 might act via the PLC-

$\mathrm{Ca}^{2+}$-PKC pathway [Flores JA et al, 1992; Choudhary E et al, 2005], details of which are discussed in subsequent chapters.

\section{Luteolysis}

The life span of the CL varies from species to species and can be altered by pregnancy and mating. Regardless of the duration of life span, the CL ultimately loses the capacity to produce P4 and undergoes structural involution. The term "luteolysis" used extensively in the literature to describe this process is defined as "degradation of the CL" (Medical Subject Headings, MeSH, US National Library of Medicine). Rothchild 
[Rothchild I, 1981] defined luteolysis as "stopping the secretion of P4 by the CL". Hoyer [Hoyer PB, 1998] referred to the decrease of P4 as "functional regression" while described the cell death as "true" regression. In contrast, Niswender et al. [Niswender GD, 2000] referred to the structural demise of the CL as luteal regression and the loss of P4 synthesis capacity by the CL as a part of the regression process. Thus, it can be broadly said that luteal regression (luteolysis) consists of two "components"; 1) an initial loss of steroidogenic and secretory function of the CL called "functional" luteolysis and 2) a subsequent morphological demise of the nonfunctional CL involving apoptosis and termed "structural" demise. There is still much controversy in the literature with respect to the appropriate terminology describing "luteolysis" or "luteal regression". This study primarily concentrates in the cellular mechanisms involved during functional luteolysis.

\section{Anti-steroidogenic effects of $\mathbf{P G F}_{2 \alpha}$}

During luteal regression, the initial decrease in P4 concentrations is not due to loss of steroidogenic cells, since the numbers of luteal cells remain unchanged until after the decrease of P4 concentration [Braden TD et al, 1988]. Functional luteolysis occurs primarily due to decreased steroidogenic capacity of individual luteal cells. In luteal steroidogenic cells (SLC and LLC), morphological changes that are indicative to apoptosis appear 24-36h after $\mathrm{PGF}_{2 \alpha}$ exposure, in contrast to the steroidogenic capacity of the cells that get markedly reduced by this time [Sawyer HR et al, 1990]. There are likely multiple mechanisms by which $\mathrm{PGF}_{2 \alpha}$ decreases $\mathrm{P} 4$ synthesis: 1) downregulation of receptors for luteotropic hormones, 2) decreased cellular uptake of lipoproteins, 3) decreased cholesterol transport and 4) decreased activity of steroidogenic enzymes required for $\mathrm{P} 4$ biosynthesis.

$\mathrm{PGF}_{2 \alpha}$ decreases mRNA of LHR, however the number of LHR does not decrease until after the concentration of P4 in the serum has already decreased [Diekman MA et al, 1978; Spicer LJ et al, 1981]. However, whether these LHR are functional or not is unclear. Prostaglandlin $\mathrm{F}_{2 \alpha}$ interferes with function of secondary messengers for $\mathrm{LH}$ [Agudo SPL et al, 198]. Prostaglandin $\mathrm{F}_{2 \alpha}$ increases phosphodiesterase activity, resulting in cAMP degradation and thereby affecting PKA activity [Garverick HA et al, 1985]. Inhibiting lipoprotein receptor expression did not have any effect on P4 synthesis 
[Wiltbank MC et al 1993]. Also, lipoprotein uptake after treatment with $\mathrm{PGF}_{2 \alpha}$ was not a limiting factor for luteal P4 secretion [Grusenmeyer DP et al, 1992]. The mRNA and protein of $\mathrm{P} 450 \mathrm{scc}$ and $3 \beta \mathrm{HSD}$ decreased after $\mathrm{PGF}_{2 \alpha}$ treatment but the activity of these enzymes did not decrease even after $24 \mathrm{~h}$ of $\mathrm{PGF}_{2 \alpha}$ treatment [Juengel JL et al, 1998a; Niswender GD et al, 2000]. Given that circulating P4 decreased within $12 \mathrm{~h}$ of $\mathrm{PGF}_{2 \alpha}$ treatment it has been proposed that inhibition of P450scc and 3 $\beta \mathrm{HSD}$ do not play critical roles in lowering P4 concentration during luteal regression [Diaz FJ et al, 2002]. Treatment with $\mathrm{PGF}_{2 \alpha}$, both in vivo and in vitro, reduced StAR mRNA in bovine luteal tissue [Diaz FJ et al, 2002]. The orphan nuclear receptor DAX-1, is thought to mediate the inhibitory effect on StAR mRNA, possibly by binding to DNA hairpin structures present in the StAR promoter [Zazopoulos E et al, 1997]. PGF $_{2 \alpha}$ also regulates StAR protein directly. There are multiple potential PKC phosphorylation sites that affect StAR activity [Arakane $\mathrm{F}$ et al, 1997]. Recently it has been reported that $\mathrm{PGF}_{2 \alpha}$ treatment decreased StAR protein in rat CL. Another target of $\mathrm{PGF}_{2 \alpha}$ action is sterol carrier protein2 (SCP-2). In rats, treatment with $\mathrm{PGF}_{2 \alpha}$ decreased the amount of SCP-2, thus lowering of cholesterol transport [McLean AS et al, 1995]. Disruption of the cytoskeleton by $\mathrm{PGF}_{2 \alpha}$ has been reported to play a role in the decrease of P4 synthesis in variety of species [Silavin SL et al, 1980; Murdoch WJ, 1996; Williams MT et al, 1979]. However,

there is contradicting evidence that disruption of cytoskeleton may also stimulate steroidogenesis. Smith and Sridaran [Smith CJ et al, 1991] reported that in CL of rats, disruption of cytoskeleton for a short time inhibited steroidogenesis while cytoskeleton disruption for a longer time stimulated steroidogenesis. However, the exact mechanism by which $\mathrm{PGF}_{2 \alpha}$ inhibits $\mathrm{P} 4$ synthesis during luteal regression is still unclear.

\section{Regulation of Luteal Regression by the Endothelial (ET) System}

Several authors have proposed that the ET system plays an essential role in $\mathrm{PGF}_{2 \alpha}$ induced luteolysis, and that $\mathrm{PGF}_{2 \alpha}$ differentially modulates the expression of genes encoding ET-1, ECE-1 and ET-A receptor at early and mid-luteal phases [Girsh E et al, 1996a; Median R et al, 1999; Girsh E et al, 1996b; Ohtani M et al, 1998; Milvae RA, 2000; Wright MF et al, 2001]. Endothelin converting enzyme 1 expression measured as 
the mRNA or protein, was reported to be 3-4 fold greater in mid cycle CL than in the early luteal phase [Levy N et al, 2001]. Concentrations of ET-A receptor mRNA and ET1 mRNA and protein were upregulated rapidly during natural or $\mathrm{PGF}_{2 \alpha}$-induced luteolysis [Girsh E et al, 1996a; Median R et al, 2002]. In contrast to these observations, Wright et al [Wright MF et al, 2001] reported that mRNA encoding ET-A and ECE-1 expression, although expressed at higher concentrations in the late luteal phase, were expressed constitutively in the early and mid CL. Furthermore, the authors proposed that ET-1 gene was most likely regulated by PGF $_{2 \alpha}$ during the mid-luteal phase. Choudhary et al [Choudhary E et al, 2004] reported the same observation, stating that all components of the luteal endothelin system (ET-1/ECE-1/ET-A/ET-B) were regulated dynamically throughout the bovine luteal phase. The authors reported the existence of a $\mathrm{PGF}_{2 \alpha^{-}}$ independent (early CL) and a dependent (late CL) phase for the regulation of the endothelin system. Activity of ECE-1 was unaltered throughout the ovarian cycle. Based on this observation, the authors proposed that the alteration of ET-1 availability is most likely achieved by the modulation of ppET-1 expression and unlikely by ECE-1.

Girsh et al [Girsh E et al, 1996b] demonstrated that ET-1 via ET-A receptor, in a dose dependent manner, inhibited basal and LH/hCG-stimulated biosynthesis of P4 in the mid luteal phase. Moreover, in studies using ET-A antagonist, the $\mathrm{PGF}_{2 \alpha}$-induced antisteroidogenic effect was decreased significantly [Milvae RA, 2000]. This led to the hypothesis that ET-1 might mediate the luteolytic actions of $\mathrm{PGF}_{2 \alpha}$. In contrast, Choudhary et al [Choudhary E et al, 2005] reported that the potency of ET-1 to inhibit both basal and LH-stimulated P4 synthesis in the mid luteal stage was greater in the early luteal phase. Furthermore, the authors proposed that ET-1 appeared to be more of a tonic inhibitor of $\mathrm{P} 4$ synthesis than a mediator of $\mathrm{PGF}_{2 \alpha}$ actions.

\section{Other Factors}

The development and physiology of the CL are regulated by number of cytokines like tumor necrosis factor (TNF), interleukin-1 (IL-1) and interferon- $\gamma$ (INF- $\gamma$ ) that are produced locally. Tumor necrosis factor $-\alpha$ and its receptors (TNFR) are present in the $\mathrm{CL}$ of many species [Sakumoto $\mathrm{R}$ et al, 2004]. Tumor necrosis factor $-\alpha$ plays multiple roles in CL throughout the estrous cycle [Okuda $\mathrm{K}$ et al, 2003]. Tumor necrosis factor - $\alpha$ 
has both luteotropic and luteolytic functions in the CL. In contrast, Fas ligand (Fas L), another member of the TNF super family, is recognized primarily for its apoptotic actions during luteal regression [Okuda $\mathrm{K}$ et al, 2003].

In the early luteal phase, expression of TNF- $\alpha$ and TNFR are evident in CL from cows [Sakumoto R et al, 2000], pigs [Wuttke W et al, 1997; Miyamoto Y et al, 2002] and human beings [Vaskivuo TE et al, 2002]. In vitro, TNF- $\alpha$ acts as a potent stimulator of luteal PGs like $\mathrm{PGF}_{2 \alpha}, \mathrm{PGE}_{2}$ and $\mathrm{PGI}_{2}$ in primary luteal cell cultures [Benyo DF et al, 1992; Schams D et al, 1995b]. During development of the CL, macrophages [Carswell EA et al, 1975; Zhao Y et al, 1998] and EC [Hehnke-Vagnoni KE et al, 1995] are the major sources of TNF- $\alpha$ [Reynolds LP et al, 1994]. It has been proposed that TNF- $\alpha$ contributes to production of PGs in early CL and may have a role in luteal development. However, it has been demonstrated that TNF- $\alpha$ inhibits gonadotropin-stimulated steroid production in luteal SC of rats [Adashi EY et al, 1990], sheep [Pitzel L et al, 1993] and cows [Benyo DF et al, 1992]. Also, secretion of TNF- $\alpha$ in bovine CL is greater in the mid-late phase compared to the early stages [Shaw DW et al, 1995; Sakumoto R et al, 2000] and TNFR are present in the bovine CL throughout the estrous cycle [Sakumoto R et al, 2000]. These authors suggested that TNF- $\alpha$ acts as a luteolytic agent in the mid-late $\mathrm{CL}$, but how it switches from a luteotropic to a luteolytic role is unknown.

It is well recognized that $\mathrm{PGF}_{2 \alpha}$ is the major luteolytic agent in mammals. It is presumed that ET-1 plays an important role in the regulation of luteal regression. Specific binding sites for TNF- $\alpha$ have been reported in cultured EC derived from bovine CL [Okuda K et al, 1999; Friedman A et al, 2000] and that ET-1 secretion is increased significantly after TNF- $\alpha$ treatment [Friedman A et al, 2000]. Moreover, in vivo, PGF $_{2 \alpha}$ activates inflammatory cells followed by TNF- $\alpha$ and INF- $\gamma$ secretion in CL of cows [Penny LA et al, 1999] and pigs [Hehnke KE et al, 1994]. Benyo et al [Benyo DF et al, 1992] reported that in primary luteal cell culture TNF- $\alpha$ in combination with INF- $\gamma$ reduced P4 secretion as well as the number of viable cells. In contrast, TNF- $\alpha$ alone had no effect on P4 synthesis [Benyo DF et al, 1992]. It has been suggested that TNF acts in conjunction with INF- $\gamma$ or other substances (eg, ET-1, NO) to inhibit P4 synthesis. 
Although TNF- $\alpha$ exerts pleiotropic responses, the engagement of Fas with the Fas $\mathrm{L}$ is known primarily for its role in apoptosis. Fas has been demonstrated to be expressed through out the luteal phase [Taniguchi $\mathrm{H}$ et al, 2002b; Taniguchi $\mathrm{H}$ et al, 2002a] However, the physiological significance of Fas or its ligand in the developing CL, is not yet known. Expression of Fas/Fas L in bovine primary luteal cell culture induced luteal cell death [Taniguchi H et al, 2002b; Pru JK et al, 2002]. Similar results have been shown in bovine granulosal cells [Quirk SM et al, 2000]. Structural demise of the CL involves interaction of the Fas/Fas L system and other cytokines (TNF, INF- $\gamma$ ). Bovine luteal cells became sensitive to Fas/Fas L-induced cell death in the presence of INF- $\gamma$ alone or in combination with TNF- $\alpha$ [Taniguchi $\mathrm{H}$ et al, 2002a]. The increased sensitivity of bovine luteal cells to Fas $\mathrm{L}$ has been correlated with cytokine-induced increase of Fas mRNA [Taniguchi $\mathrm{H}$ et al, 2002a].

Tumor necreosis factor-R1 mRNA and specific binding sites for TNF- $\alpha$ are present in the bovine CL throughout the estrous cycle [Sakumoto $\mathrm{R}$ et al, 2000]. In a species dependent manner, TNF- $\alpha /$ TNFR1 complex activated different types of signaling pathways. For example in rats, TNF- $\alpha$ induced the PLC-PKC pathway [Zachow R et al, 1993a] and the cAMP-PKA pathway [Zachow R et al, 1993b]. Also in rat GC, TNF- $\alpha$ activated cell survival pathways, involving NFkB [Xiao CW et al, 2002]. In the early bovine CL, TNF- $\alpha$ via the MAPK pathway, activated the PLA2 pathway to stimulate PG synthesis [Benyo DF et al, 1992; Sakumoto R et al, 2000]. In contrast, in primary bovine luteal cell cultures, inhibitors of PKA and PKC did not affect the actions of TNF- $\alpha$ [Sakumoto $\mathrm{R}$ et al, 2000, Sakumoto $\mathrm{R}$ et al, 2004]. In vitro, TNF- $\alpha$ and INF- $\gamma$, acting via TNFR1 activated MAPK-JNK intracellular effectors that in turn activated the apoptotic cascade resulting in structural luteal regression [Okuda $\mathrm{K}$ et al, 2003].

It has been proposed that nitric oxide (NO) might be a mediator and / or modulator of $\mathrm{PGF}_{2 \alpha}$-induced luteolytic actions in the bovine CL [Skarzynski DJ et al, 2000; Skarzynski DJ et al, 2003; Jaroszewski JJ et al, 2003]. Nitric oxide directly inhibits P4 secretion in cultured bovine luteal cells and augments the action of extragonadal $\mathrm{PGF}_{2 \alpha}$ on the CL [Skarzynski DJ et al, 2000]. Moreover, in cattle, inhibition of NO production in the female reproductive tract counteracts both spontaneous [Jaroszewski JJ 
et al, 2000] and $\mathrm{PGF}_{2 \alpha}$-induced luteolysis [Skarzynski DJ et al, 2003; Jaroszewski JJ et al, 2003]. In bovine CL, NO stimulated secretion of leukotrine C4 (LTC4) that was shown to play a role in luteal regression [Jaroszewski JJ et al, 2003]. In heifers, an in vivo microdialysis experiment demonstrated that LTC4 concentration in perfusates from the CL rose before the decline in P4 during spontaneous luteal regression [Blair RM et al, 1997]. 


\section{Chapter II: Statement of Problem}

The CL of the early estrous cycle (days 1-5) is resistant to the luteolytic action of a single dose of $\mathrm{PGF}_{2 \alpha}$ that induces luteal regression in the mid-late (days 8-15) CL. Resistance is not due to the lack of $\mathrm{PGF}_{2 \alpha}$ receptors, as the receptor already exists in maximal concentration in the early CL [Wiltbanl MC et al, 1995]. The mechanism(s) responsible for the insensitivity of the early CL are poorly understood, however several possibilities have been proposed. It has been reported that the early CL has a greater ability to catabolize $\mathrm{PGF}_{2 \alpha}$ to PGFM [Silva PJ et al, 2000]. Catabolism of $\mathrm{PGF}_{2 \alpha}$ locally in the CL might prevent $\mathrm{PGF}_{2 \alpha}$, of uterine origin, from reaching its receptors in the CL. However, because PGDH is a cytosolic enzyme, it is more likely that PGDH opposes the biosynthetic function of COX-2 in the $\mathrm{CL}$, preventing local accumulation of $\mathrm{PGF}_{2 \alpha}$. It also has been proposed that the early $\mathrm{CL}$ lacks $\mathrm{PGF}_{2 \alpha}$ synthetic capacity. Tsai and Wiltbank [Tsai SJ et al, 1997] reported that $\mathrm{PGF}_{2 \alpha}$ amplifies the luteolytic signal from the uterus in a paracrine/autocrine manner only in the mid-late luteal phase. However, Sayre et al [Sayre BL et al, 2000] found that repeated treatment with $\mathrm{PGF}_{2 \alpha}$ upregulated $\mathrm{PG} / \mathrm{H}$ synthase 2 and PGF synthase in day-4 CL. This observation indicated that a difference in sensitivity and not lack of $\mathrm{PGF}_{2 \alpha}$ synthetic capacity in the early CL might be the primary cause for the insensitivity of the early CL. Choudhary et al [Choudhary E et al, 2005] recently reported that the potency of $\mathrm{PGF}_{2 \alpha}$ and ET-1 to inhibit basal and LH-stimulated P4 accumulation in luteal SC primary cultures from day-4 CL was lower than that of day10.

There is compelling evidence that a threshold dosage of $\mathrm{PGF}_{2 \alpha}$ is required before the CL is committed to luteolysis [Silvia WJ et al, 1986; Juengel JL et al, 2000]. Thus, a major biological function of PGDH in the CL has been hypothesized to prevent luteal concentrations of $\mathrm{PGF}_{2 \alpha}$ from reaching threshold amounts to initiate luteal regression at an inappropriate time. The fact that increased PGDH enzymatic activity is correlated temporally with luteal resistance supports the existence of such a mechanism [Silva, PJ et al, 2000]. 
In the early CL of the cow and the ewe, expression of COX-2 does not increase in response to exogenous $\mathrm{PGF}_{2 \alpha}$ [Tsai SJ et al, 1997]. Because there is high catabolism of $\mathrm{PGF}_{2 \alpha}$ in the early CL, the stimulatory effects of $\mathrm{PGF}_{2 \alpha}$ on luteal expression of COX-2 are blunted. Based on this observation, it has been proposed that the insensitivity of the early CL may be due to a blockage of $\mathrm{PGF}_{2 \alpha}$-induced expression of COX-2 [Silva, PJ et al, 2000]. In addition, regulation of expression of different PG receptors and PGF synthase, PGE synthase and prostacyclin synthase also influence the type of PG produced by the CL, and consequently may alter the function of the CL. Arosh et al [Arosh JA et al, 2004b] demonstrated selective activation of $\mathrm{PGE}_{2}$ synthase and EP2 signaling during luteal maintenance and increased expression of PGF synthase and EP3 during luteal regression. Based on their observations, they proposed that selective expression of luteal $\mathrm{PGE}_{2}$ and/or $\mathrm{PGF}_{2 \alpha}$, their extra-cellular transportation by PGT and the differential expression of PGE and/or PGF receptors and their intracellular mediators during distinct stages of the CL life may lead to luteal maintenance or demise. These observations may help to understand the mechanism of luteal regression, but fail to explain the cause of early luteal insensitivity to the luteolytic actions of $\mathrm{PGF}_{2 \alpha}$. If $\mathrm{PGF}_{2 \alpha}$ availability is the primary reason for the insensitivity of the early CL, exogenous $\mathrm{PGF}_{2 \alpha}$ treatment should cause luteal regression. However, in the early CL, both in vivo [Rowson LE et al, 1972] and in vitro [Choudhary E et al, 2005], treatment with $\mathrm{PGF}_{2 \alpha}$ failed to induce luteal regression.

Another proposal put forward by many authors as a possible cause for the resistance of early $\mathrm{CL}$ is the inability of $\mathrm{PGF}_{2 \alpha}$ to induce ET-1 synthesis at this developmental stage [Levy $\mathrm{N}$ et al, 2000]. However, in the early CL, the expression of ET-1 system was $\mathrm{PGF}_{2 \alpha}$-independent [Wright MF et al, 2001; Choudhary E et al, 2004) and Choudhary et al (Choudhary E et al, 2005] has demonstrated that ET-1 instead of being strictly a mediator of the luteolytic actions of $\mathrm{PGF}_{2 \alpha}$, is a tonic inhibitor of P4 accumulation. Based on this study, the authors proposed that the insensitivity of the early $\mathrm{CL}$ to the luteolytic actions of $\mathrm{PGF}_{2 \alpha}$ is related to differences in developmental sensitivity to $\mathrm{PGF}_{2 \alpha}$ rather than to the absence of ET-1 to mediate the luteolytic action of $\mathrm{PGF}_{2 \alpha}$. In 
mid-late luteal phase, it is hypothesized that tonic inhibition of P4 by ET-1 along with $\mathrm{PGF}_{2 \alpha}$ and possibly with other factors mentioned above, may cause luteal regression.

Juengel and Niswender [Juengel JL et al, 1998b] have proposed that the sensitivity of the ovine $\mathrm{CL}$ to the luteolytic actions of $\mathrm{PGF}_{2 \alpha}$ is regulated at the postreceptor/intracellular mediator level. In support of this suggestion, it was demonstrated [Juengel JL et al, 1998b] that the concentrations of mRNA encoding PKC inhibitor protein-1 (KCIP-1) in day-4 CL is greater than in day-10 and $15 \mathrm{CL}$. The authors proposed that increased resistance of the corpus luteum to $\mathrm{PGF}_{2 \alpha}$ might be attributable to greater concentrations of this biological inhibitor of $\mathrm{PKC}$, and as a result, $\mathrm{PGF}_{2 \alpha}$ fails to fully activate its intracellular mediators. Another suggestion regarding difference in the intracellular mediators of $\mathrm{PGF}_{2 \alpha}$ as a function of development is that there may exist a threshold of $\left[\mathrm{Ca}^{2+}\right]_{\mathrm{i}}$ that is required to support P4 synthesis, while a change in $\left[\mathrm{Ca}^{2+}\right]_{\mathrm{i}}$ may lead to luteal regression [Martinez-Zaguilan $\mathrm{R}$ et al, 1994; Wegner JA et al, 1991].

It has been known for some time that PKC and calcium are intracellular mediators of $\mathrm{PGF}_{2 \alpha}$ and is well established that individual PKC isoforms have very specific functions and may cause antagonistic effects in the same tissue or cell type. However, nothing is known about the array of PKC isozymes expressed in the bovine CL or the biological functions of individual PKC isoforms. It is likely that among the PKC isoforms expressed in the bovine CL, some might be luteotropic while others might have luteolytic actions. These studies investigated the array of PKC isozymes expressed in the bovine $\mathrm{CL}$, their cellular source and potential roles of specific PKC isozymes involved in the early and mid-luteal phase of bovine CL. 


\section{Chapter III: Expression and Activation of Protein Kinase C Isozymes by Prostaglandin $F_{2 \alpha}$ in the Early and Mid-Luteal Phase Bovine Corpus Luteum}

\section{Introduction}

The luteolytic actions of prostaglandin $\mathrm{F}_{2 \alpha}\left(\mathrm{PGF}_{\alpha}\right)$ are mediated by the activation of its plasma membrane receptor, a G-protein coupled receptor. In the CL, PGF $2_{\alpha}$ binding to its cognate receptor activates the membrane-bound phosphoinositide-specific phospholipase C (PLC), yielding inositol 1,4,5-trisphosphate $\left(\mathrm{IP}_{3}\right)$ and diacylglycerol [Davis JS et al, 1987]. In bovine luteal cells PGF $_{2 \alpha}$ stimulates phosphatydylinositol 4,5biphosphate hydrolysis and mobilizes intracellular $\mathrm{Ca}^{2+}$ [Davis JS et al, 1987; Davis JS et al, 1988]. Accordingly, calcium and protein kinase C (PKC) have been shown to be the intracellular mediators of actions of $\mathrm{PGF}_{2 \alpha}$ in the CL [Wiltbank MC et al, 1991]. PKC is a family of protein kinases that exist in 11 isozymes examined to date [Sakanoue $\mathrm{Y}$ et al, 1992; Selzer E et al, 2002]. There are 4 conventional PKC isozymes, alpha $(\alpha)$, beta I $(\beta \mathrm{I})$, beta II $(\beta \mathrm{II})$, and gamma $(\gamma) ; 4$ novel PKC, delta $(\delta)$, epsilon $(\varepsilon)$, theta $(\theta)$, and eta $(\eta)$; and 3 atypical, lambda $(\lambda)$, zeta $(\zeta)$, and $\mathrm{mu}(\mu)$. The PKC $\mu$ is also known as PKD [Selzer E et al, 2002]. Surprisingly, the array of PKC isozymes expressed, their subcellular distribution and their roles in the regulation of luteal function, have received very little attention. In the $\mathrm{CL}$ of the mid-luteal phase, the $\alpha$-(in cytosol) and $\varepsilon$-(in plasma membrane) isozymes have been reported to be immunonochemically detectable [Orwig KE et al, 1994].

In cows and various other animals in which $\mathrm{PGF}_{2 \alpha}$ induces luteolysis, the $\mathrm{CL}$ of the early estrous cycle (days 1-5) is resistant to the luteolytic action of a dose of $\mathrm{PGF}_{2 \alpha}$ that induces luteolysis in mid-late (days 8- 15) CL. Resistance of the early CL to $\mathrm{PGF}_{2 \alpha}$ is not because of the lack of receptors, because those are already maximal at this stage of the cycle [Mamluk R et al, 1999; Wiltbank MC et al, 1995]. The mechanism(s) responsible for insensitivity of the early $\mathrm{CL}$ to $\mathrm{PGF}_{2 \alpha}$ are not fully understood, however several possibilities have been implicated. For instance, a greater ability of the early- than late-CL to inactivate $\mathrm{PGF}_{2 \alpha}$ has been documented [Silva PJ et al, 2000]. There is evidence 
that the early-CL lacks PGF $2 \alpha$ synthetic capacity. Tsai and Wiltbank, 1997 [Tsai SJ et al, 1997] reported that $\mathrm{PGF}_{2 \alpha}$ amplifies the luteolytic signal from the uterus in a paracrine/autocrine manner only during the mid-and late-cycle ovine and bovine CL. However, Sayre et al. 2000 [Sayer BL et al, 2000] found that repeated treatment with $\mathrm{PGF}_{2 \alpha}$ up-regulated prostaglandin $\mathrm{G} / \mathrm{H}$ synthase 2 and $\mathrm{PGF}_{2 \alpha}$ synthase in Day-4 CL. This observation by Sayre et al. [Sayer BL et al, 2000] stresses a difference in sensitivity rather than a lack of $\mathrm{PGF}_{2 \alpha}$ synthetic capacity in the early CL. Levy et al. [Levy N et al, 2000] reported another possible cause for resistance of early CL. These investigators have proposed that the endothelin (ET) system plays an essential role during $\mathrm{PGF}_{2 \alpha}$ induced luteolysis, and that $\mathrm{PGF}_{2 \alpha}$ differentially modulates the expression of the genes encoding ET-1, the ET receptor type A and the ET converting enzyme-1 (ECE-1) at the early and mid luteal phases [Levy N et al, 2000; Meidan R et al, 1999, Girsh E et al, 1996a; Girsh E et al, 1996b; Ohtani M et al, 1998; Milvae RA et al, 2000]. The work by these investigators has led to the hypothesis that the limited ability of $\mathrm{PGF}_{2 \alpha}$ to stimulate ET-1 synthesis during the early luteal phase may be responsible for the insensitivity of the early CL to $\mathrm{PGF}_{2 \alpha}$.

Although $\mathrm{PGF}_{2 \alpha}$ reaches the early corpus luteum (CL), can bind to its cognate receptor, and initiate some of the events that lead to luteolysis, the early CL is resistant to the luteolytic actions of $\mathrm{PGF}_{2 \alpha}$. The possibility that cellular mechanisms acting at the post receptor level (i.e. intracellular signal transduction) might contribute to this insensitivity or resistance of the early CL has not been explored. For example, there is no information available regarding expression of the PKC isozymes as a function of the developmental age of the $\mathrm{CL}$, or about the ability of $\mathrm{PGF}_{2 \alpha}$ to induce their activation in the early- and late-luteal phases.

Here we have examined by, a semi quantitative Western blotting analysis, the array of PKC isozymes expressed by the bovine CL at two developmental stages, days 4 and 10 of the estrous cycle. Furthermore, because a unifying theme in the activation of these isozymes is that $\mathrm{PKC}$ activation results in rapid redistribution of $\mathrm{PKC}$ from the cytosol to the membrane, we have examined membrane translocation of PKC after in vitro stimulation with $\mathrm{PGF}_{2 \alpha}$ of luteal tissue collected on days 4 and 10 of the estrus 
cycle.

\section{Materials and Methods}

Behavioral estrus was determined in 10 nonlactating beef cows. After three consecutive cycles, five Day-4 (d-4) and five Day-10 (d-10) corpora lutea were collected via supravaginal incision under epidural anesthesia. Corpora lutea were dissected free of any connective tissue and then cut into approximately $1 \mathrm{~mm}^{2}$ fragments immediately before the experiments were initiated. About $25 \mathrm{CL}$ fragments were added to a disposable culture tube/treatment/time (Fisher Scientific, Pittsburgh, PA) containing MEM-HEPES (GIBCO BRL, Life Technologies, Grand Island, N.Y.) alone or MEM-HEPES containing 0.1, 1.0 and $10 \mathrm{nM} \mathrm{PGF}_{2 \alpha}$ (Cayman Chemical, Ann Arbor, Michigan). The $\mathrm{PGF}_{2 \alpha}$ stock solution was prepared in dymethylsulfoxide (DMSO, Pierce, Rockford, IL) and there was a $1: 10,000$ dilution $(\mathrm{v} / \mathrm{v})$ of the DMSO in MEM-HEPES to obtain the $10 \mathrm{nM}$ concentration of $\mathrm{PGF}_{2 \alpha}$. The MEM-HEPES control received the same amount of DMSO as the $\mathrm{PGF}_{2 \alpha}$ treatment. The tissue and media were separated after $0,2.5,5,10$ and 20 min, immediately frozen in liquid nitrogen and stored at $-80^{\circ} \mathrm{C}$.

The tissue was later pulverized and homogenized in buffer containing $20 \mathrm{mM}$ Tris-HCl, 0.25-mol sucrose, $1.2 \mathrm{mM}$ EGTA, $0.1 \mathrm{mM}$ Phenylmethylsulfonyl Fluoride (PMSF, Eastman Kodak Company, Rochester, NY), $20 \mu \mathrm{g} / \mathrm{ml}$ leupeptin, and $20 \mathrm{mM}$ 2mercaptoethanol (GIBCO BRL, Life Technologies, Grand Island, N.Y.). The homogenized tissue was centrifuged at $1,000 \mathrm{Xg}$ for $2 \mathrm{~min}$ at $4^{0} \mathrm{C}$ to remove floating large tissue particles. The supernatant was used for sub-cellular fractionation by differential and discontinuous sucrose gradient centrifugation. The cytosol fraction was obtained by centrifugation at $100,000 \mathrm{Xg}$ for $60 \mathrm{~min}$. The pellet of the first $100,000 \mathrm{Xg}$ centrifugation was homogenized in homogenization buffer containing $1 \%$ triton-X 100 . The homogenized pellet was re-centrifuged at $100,000 \mathrm{X} \mathrm{g}$ for $60 \mathrm{~min}$. The supernatant constituted the membrane fraction. Protein concentrations in the cytosolic and membrane fractions were determined using a BioRad assay (BioRad, Hercules, CA) with BSA (GIBCO BRL, Life Technologies, Grand Island, N.Y.) as standards. Sample proteins were analyzed by semi quantitative Western blotting as previously described [Wright Mf 
et al, 2001]. For semi quantitative analysis of the PKC isozymes, the protein concentration in samples was adjusted to $8.0 \mu \mathrm{g} /$ lane.

The SDS-PAGE was carried out as previously described [Wright Mf et al, 2001]. Briefly, protein samples were loaded onto $8 \%$ polyacrylamide gel. After electrophoresis at $150 \mathrm{~V}$ for $1 \mathrm{hr}$, the resolved proteins were transferred to polyvinylidene fluoride membrane (Biotechnology Systems, Boston, MA). The membranes were blocked in 1\% BSA with $0.05 \%$ Tween-20 in Tris-buffered saline (TBS-T, $\mathrm{pH} 7.5$ ) for $2 \mathrm{hr}$ at room temperature. The membranes were incubated with primary antibody for $2 \mathrm{hr}$ at room temperature and washed three times for 10min in TBS-T. Subsequently, the membranes were incubated with anti-rabbit $(1: 5000[\mathrm{v} / \mathrm{v}]$; Amersham Pharmacia Biotech, Piscataway, NJ) or anti-mouse $(1: 30,000[\mathrm{v} / \mathrm{v}]$; Gibco, Grand Island, NY) horseradish peroxide-conjugated antibodies for $1 \mathrm{hr}$. Visualization of the selected proteins was achieved using the WestPico detection system (Pierce, Rockport, IL) and Kodak Biomax Light Film (Eastman Kodak Company, Rochester, NY). This system was selected because of its versatility in allowing the stripping of primary and secondary antibodies from membranes for sequential re-probing of membranes with variety of antibodies.

Stripping of membranes was performed with Restore Western Blot Stripping Buffer (Pierce, Rockport, IL). Stripping conditions were tested to demonstrate complete removal of antibodies, and $30 \mathrm{~min}$ at room temperature was found to be effective for all antibodies used in this study. Images of the detected proteins were captured using the Fluor-S MultiImager. Densitometry of the bands of interest was performed using Quantity One quantitation software. The intensity of the signal corresponding to the protein of interest was standardized by the corresponding intensity of the actin control in that sample. This normalization of data allowed us to estimate, in a semi quantitative manner, the amount of protein in the samples of interest. This semi quantitative Western blot methodology has been described earlier [Wright Mf et al, 2001]. The following primary antibodies were used in these studies. A mouse anti-actin monoclonal antibody ([used at a dilution of 1:3000 (v/v] Chemichon International, Inc., Temecula, CA); nine PKC isozyme specific ( $\alpha, \beta \mathrm{I}, \beta \mathrm{II}, \gamma, \eta, \varepsilon, \theta, \lambda$, and $\mu$ ) polyclonal antibodies and their antigenic peptides ([antibodies used at dilution 1:1000] Gibco, Grand Island, NY). 


\section{Statistical Analysis}

Statistical analyses were performed using JMP, a statistical software program for the Apple Macintosh [Cary NC, 1994]. The analysis was based on the ratio of optical density (arbitrary units) for the PKC isozyme divided by the optical density for actin. The results were expressed as the mean \pm SEM. Two-way ANOVA followed by the TukeyKrame Honesty Significant Difference was used to determine statistical significant differences between the days of cycle and the effect of the $\mathrm{PGF}_{2 \alpha}$ treatment. A value of $\mathrm{P}$ $<0.05$ was considered significant.

\section{Results}

PKC isozymes Expressed in the Bovine CL

The antibodies specific for the PKC isozymes detected protein bands of approximately $80 \mathrm{kDa}$ in some of the luteal samples examined (Figure 1). This molecular weight corresponded closely to the published size bands detected for the different PKC isozymes [Blumberg PM, 1991]. These $80 \mathrm{kDa}$ bands were detected when the samples were used at concentrations of 5 to $50 \mu \mathrm{g}$ (Figure 1A); at lower protein concentrations no bands were detected (data not shown). Based on these findings, sampled proteins were at a total protein concentration of at least $8 \mu \mathrm{g}$ to evaluate the $\mathrm{PKC}$ isozymes present in the d 4 and d 10 bovine CL. The specificity for each of isozyme-specific antibodies was confirmed by incubation of each antibody with excess antigenic peptide; an example for specificity of the PKC $\beta$ I antibody is shown in Figure 1B. In all samples examined, a 43kDa-protein band was detected with the antibody for actin (Figure 1C). This molecular weight corresponded closely to the published size band for actin [Otey CA et al, 1987]. The specificity of the band detected with the actin antibody has been similarly confirmed elsewhere [Otey CA et al, 1987].

Specific protein bands corresponding to the conventional PKC isozymes $\alpha, \beta I$, and $\beta$ II were detected in the protein samples prepared from both $d 4$ and $d 10$ corpora lutea. In contrast, no protein was detected with the antibody for the conventional PKC $\gamma$. With antibodies corresponding to the novel PKC group, only the PKC $\varepsilon$ was detected; the antibodies corresponding to PKC $\eta, \lambda$, and $\theta$ isozymes failed to detect 
protein bands in the bovine CL (data not shown). The antibody specific for the PKC $\mu$ isozyme detected a protein band of the appropriate size in both $\mathrm{d} 4$ and 10 luteal protein samples (data not shown).

The semi-quantitative Western blot analysis allowed us to estimate the amount of protein corresponding to each PKC isozyme expressed in the samples prepared from d-4 and $-10 \mathrm{CL}$ (Figure 2). The PKC $\beta \mathrm{II}$ and $\varepsilon$ isozymes were differentially expressed at these two developmental stages of the bovine CL. For the $\varepsilon$ isozyme, this difference was dramatic. In the day 4 samples this protein was barely detectable (Figures 1 and 2). In contrast, in the $\mathrm{d}-10$ samples, the actin corrected ratio for PKC $\varepsilon$ was $1.16 \pm 0.13$. This ratio was higher than that detected for PKC $\beta \mathrm{I}$ and $\mu$ at this developmental phase of the bovine $\mathrm{CL}(\mathrm{P}<0.01)$, but it was comparable to the ratio detected for the $\mathrm{PKC} \alpha$, and $\beta$ II (Figure 2). The PKC $\beta$ II isozyme, was differentially expressed in a less dramatic manner than PKC $\varepsilon$. The actin-corrected ratio for this PKC in the $\mathrm{d} 10-\mathrm{CL}$ was $0.85 \pm 0.2$, while in the d-4 CL, it was only $0.35 \pm 0.09(\mathrm{P}<0.01)$. The actin-corrected ratios for all other PKC isozymes did not differ with day, $\alpha(\mathrm{d}-4=0.93 \pm 0.16, \mathrm{~d}-10=0.97 \pm 0.09), \beta \mathrm{I}(\mathrm{d}-4$ $=0.54 \pm .073, \mathrm{~d}-10=0.48 \pm 0.74$, and $\mu,(\mathrm{d}-4=0.21 \pm .042, \mathrm{~d}-10=0.21 \pm 0.38$, Figure 2$)$.

The $\mathrm{PGF}_{2 \alpha}$ treatment at concentrations less than $10 \mathrm{nM}(0.1$ and 1.0$)$ had no effect on the redistribution of PKC isozymes from cytoplasm to membrane (data not shown). The time-course for the cellular distribution of the expressed PKC isozymes after $10 \mathrm{nM}$ $\mathrm{PGF}_{2 \alpha}$ stimulation was variable. For instance, for PKC $\alpha, 4 / 5$ samples from d 10 showed clear translocation from the cytosol to membrane fraction. The two patterns observed for $\mathrm{PKC}$ translocation is shown in Figure $3 \mathrm{~A}$ for $\mathrm{PKC} \alpha$. After 5 minutes exposure to $\mathrm{PGF}_{2 \alpha}$ $(10 \mathrm{nM})$, the optical density of the membrane to cytosol ratio corrected by actin was elevated over the ratio observed before $\mathrm{PGF}_{2 \alpha}$ exposure (Time 0 ). This elevated ratio indicated a redistribution of the PKC $\alpha$ from the cytosol to the membrane compartment. The increased ratio (Figure $3 \mathrm{~A}$ and $\mathrm{B}$ ) reached a peak after 10 minutes, and by 20 minutes, it had returned to values observed at time 0 . In the second pattern however, the ratio was not maximal until time $10 \mathrm{~min}$, and remained elevated through 20 minutes. Based on these observations, 10 minutes was chosen as the best time point for examining the cellular redistribution of the $\mathrm{PKC}$ isozymes after $\mathrm{PGF}_{2 \alpha}$ stimulation at these two 
developmental stages of the bovine CL.

A summary of the cellular redistribution of the expressed PKC isozymes after 10 min stimulation with $\mathrm{PGF}_{2 \alpha}(10 \mathrm{nM})$ of the d-4 and d-10 luteal tissue is presented in Table 1. The data are presented as mean \pm SEM ratio of the optical density (o.d., arbitrary units) detected for the PKC isozyme, corrected by the o.d. detected for actin on that sample.

The isozymes PKC $\alpha, \beta \mathrm{I}$, and $\beta \mathrm{II}$ were detected exclusively in the cytoplasm prepared from the d- 4 MEM-Hepes -treated group, the membrane fractions had no detectable PKC (Table 1). In contrast, treatment with $10 \mathrm{nM} \mathrm{PGF}_{2 \alpha}$ induced the association of the PKC $\alpha, \beta \mathrm{I}$, and $\beta \mathrm{II}$ isozymes with the membrane fractions, so that now these isozymes were readily detected on the membrane fractions of these d-4 samples (see Table 1). The distribution of the PKC $\mu$ and $\varepsilon$ isozymes could not be assessed due to its low expression.

In the d-10 samples treated with MEM-Hepes, (Table 1) PKC $\alpha$ (see also Figure 4) and $\varepsilon$ were detected only in the cytoplasm while PKC $\beta$ I and $\beta$ II were detected in both the cytoplasm and membrane fractions. Treatment with $10 \mathrm{nM} \mathrm{PGF}_{2 \alpha}$ induced the appearance of the PKC $\alpha$ and $\varepsilon$ in the membrane fractions, and consequently these isozymes were detected in both cellular compartments (Table 1). After treatment with $\mathrm{PGF}_{2 \alpha}$, the PKC $\beta \mathrm{I}$ and $\beta \mathrm{II}$ were still detected in both the cytoplasm and membrane fractions, but the actin-corrected ratio for these isozymes were $1.18 \pm .06$ and $1.45 \pm 0.05$ respectively $(\mathrm{P}<0.05)$. However, the actin-corrected ratios for the cytoplasmic fractions of the $\mathrm{PGF}_{2 \alpha}$-treated samples also were greater than those of the MEM-Hepes-treated controls. When this was taken into account, only the PKC $\beta$ I appeared to be translocated after the $\mathrm{PGF}_{2 \alpha}$-treatment. The observed increase of some isozymes in both cytosolic and membrane factions after $\mathrm{PGF}_{2 \alpha}$-treatment could be due to concomitant changes in the state of the actin, and thus in the amount which finally appears in the fraction. This is obviously a drawback of this approach to assess activation PKC. The distribution of the $\mathrm{PKC} \mu$ isozyme could not be assessed due to its low expression. 


\section{Discussion}

In this study we have demonstrated that the array of PKC isozymes expressed by the bovine CL is wider than it had been reported previously. Orwig et al., 1994 [Orwig $\mathrm{KE}$ et al, 1994] reported the expression of the PKC $\alpha$ and $\varepsilon$ in the bovine CL of the midluteal phase. These investigators were not able to reveal the PKC $\beta \mathrm{I}, \beta \mathrm{II}$ or $\mu$, which we were able to demonstrate in this study. Chen et al., 2001 [Chen D et al, 2001] reported the PKC $\alpha, \beta \mathrm{II}$ and $\varepsilon$ in bovine luteal tissue isolated from ovaries from early pregnancy. The reason for this discrepancy between these two studies and the study by Orwig et al., 1994 [Orwig KE et al, 1994] could the different detection systems used in these two studies. Orwig et al, 1994 [Orwig KE et al, 1994] used a colorimetric detection system, while Chen et al., 2001 [Chen D et al, 2001] and the present study used a chemiluminescent substrate. These detection systems are respectively at the low and high ends of the sensitivity spectrum of the available methodology. Some of the PKC isoforms revealed in the present study were difficult to detect even with this high sensitivity detection system, so it is not surprising that the colorimetric detection system, did not detect these isozymes expressed in low amounts.

More importantly, in this study it was demonstrated that the PKC $\varepsilon$ and $\beta$ II are expressed differently according to the developmental age of the CL. The most dramatic difference was that for the PKC $\varepsilon$ which was barely detectable in the d-4 CL with this assay. In contrast, in the d-10 CL the expression of the PKC $\varepsilon$ was unregulated considerably. The expression of the PKC $\beta$ II was higher in the d-10 than in the $\mathrm{d} 4 \mathrm{CL}$

The potential physiological significance for this differential PKC expression between these two developmental luteal stages is that it could be a contributing factor, not only in the resistance of the early CL to the luteolytic action of $\mathrm{PGF}_{2 \alpha}$, but also in the reported differential sensitivity to $\mathrm{PGF}_{2 \alpha}$ to evoke luteal oxytocin secretion and on its effects on progesterone secretion [Cluster $\mathrm{EE}$ et al, 1995]. It is possible that the expression of the full array of PKC isoymes during the mid-luteal phase confers a broader network of intracellular mediators, transducing a full range of luteolytic actions of $\mathrm{PGF}_{2 \alpha}$ in the d-10 CL. Partial expression of the array of PKC isozymes at earlier developmental stages would render the tissue differentially sensitive to alternative selective effects of 
$\mathrm{PGF}_{2 \alpha}$, without triggering the luteolytic program prematurely.

The observed differential sensitivity of the corpus luteum to $\mathrm{PGF}_{2 \alpha}$ is without doubts a complex and interesting biological phenomenon. Most likely, multiple cellular mechanisms are involved, including existence of multiple receptors, activation of different signal transduction/second messenger systems by a single class of receptor, differential developmental regulation of the intracellular mediators as well as targeting different genes at different developmental stages, with the intracellular network transducing the actions of the ligand. Although there are several studies indicating the existence of low and high affinity receptors in the CL, a single class of high affinity $\mathrm{PGF}_{2 \alpha}$ binding site has been demonstrated in the bovine CL [Wiltbank MC et al, 1995]. However, more recently, two alternative mRNA splicing giving rise to two $\mathrm{PGF}_{2 \alpha}$ receptor isoforms, which differ in their regulation by $\mathrm{PKC}$, have been described [Srinivasan D et al, 2002].

In addition to the phospholipase $\mathrm{C}$ pathway, there is some evidence that $\mathrm{PGF}_{2 \alpha}$ activates the phospholipase D pathway [Liu B et al, 1996] in cells of the Chinese hamster ovary transfected with the bovine $\mathrm{PGF}_{2 \alpha}$ receptor. These findings have been corroborated in functional rat luteal tissue [Yamamoto $\mathrm{H}$ et al, 1995]. As far as we know, evidence for differential expression of PKC isozymes at developmental stages of the bovine CL characterized by resistance and responsiveness to luteolytic actions of $\mathrm{PGF}_{2 \alpha}$ has not been obtained previously.

PKC $\varepsilon$ belongs to the novel PKC isozymes, characterized as calcium independent, but diacylglycerol -sensitive serine/threonine kinase. Its activation appears to regulate various physiological functions including the endocrine system. For example, PKC $\varepsilon$ has been implicated as a mediator of both basal and thyrotropin-releasing hormonestimulated prolactin secretion [Pickett CA et al, 2002]. Further studies are needed for understanding the luteal biological functions for this PKC isozyme.

Translocation of PKC, detected by Western blotting, although not the best or most direct proof for PKC activation, provided strong evidence for $\mathrm{PGF}_{2 \alpha}$-stimulated PKC activation in both $\mathrm{d}-4$ and $\mathrm{d}-10$ luteal samples. Therefore if the signal transduction associated with the luteal $\mathrm{PGF}_{2 \alpha}$ receptor, $\mathrm{PKC}$, contributes to the mechanism responsible 
for insensitiveness of the d-4 CL, it is most likely mediated through differences in expression of PKC $\varepsilon$ and $\beta$ II isozymes at this stage. It appears unlikely that the observed insensitiveness is due to the inability of the $\mathrm{PGF}_{2 \alpha}$ receptor to activate the expressed isozymes in the early CL. We argue that differences in expression of isozyme complement are responsible for differences in response to PGF2a between day 4 and 10 luteal tissue.

In summary, the PKC $\alpha, \beta \mathrm{I}, \beta \mathrm{II}, \varepsilon$ and $\mu$ isozymes were detected in total protein samples prepared from both $\mathrm{d}-4$ and $\mathrm{d}-10$ bovine corpora lutea. The PKC $\beta \mathrm{II}$ and $\varepsilon$ isozymes were expressed differentially at these two developmental stages of the CL. We propose that differential expression of these PKC isozymes is part of the cellular mechanism responsible for the relative insensitivity of the early CL to the luteolytic actions

of

$\mathrm{PGF}_{2 \alpha}$. 


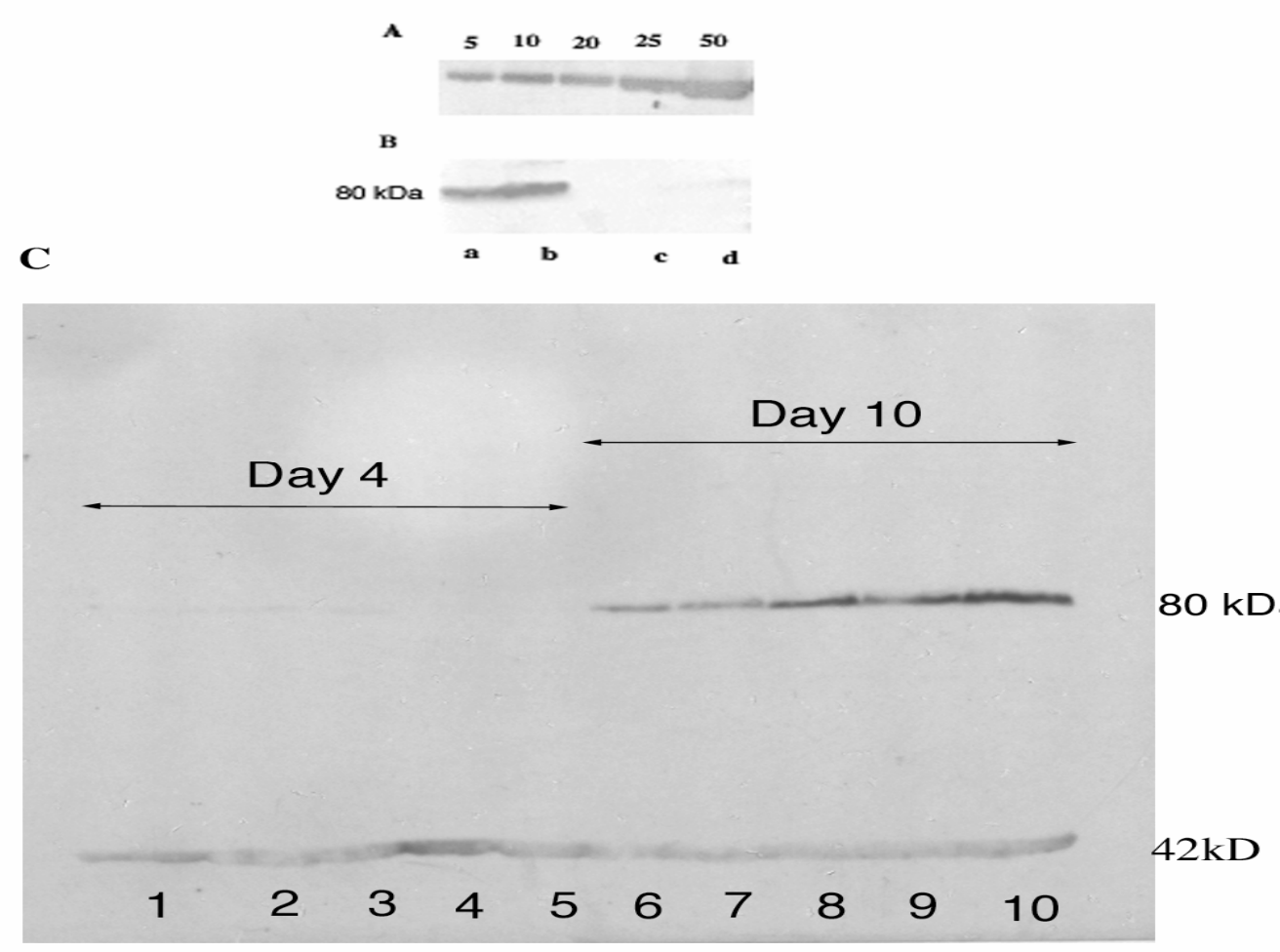

Figure 1. Representative validation used in the semi quantitative Western blot analysis of the PKC isozyme array expressed in the bovine. Figure 1A demonstrate the amount of total sample protein needed to detect the luteal PKC isozymes; a representative Western blot corresponding to the PKC $\beta$ I is shown in panel A. Panel B demonstrate the specificity of the Western blot obtained with the PKC $\beta$ I antibody. In this representative Western blot shown, the samples were run in duplicate at a protein concentration of 25 $\mu \mathrm{g}$. Lanes $\mathrm{c}$ and $\mathrm{d}$ correspond to the experimental conditions where the primary antibody was pre-incubated with an excess amount of antigenic peptide prior to its use in the Western blot. Panel $\mathrm{C}$ demonstrate the differential expression of PKCE isozyme in the early- (day 4) and mid- (day 10) phase of the bovine CL. This representative Western blot demonstrates the amount of PKCE and actin expressed in protein samples prepare from bovine corpora lutea collected at $d-4(n=5$, lanes $1-5)$ and $d-10(n=5$, lanes $6-10)$ of the estrous cycle. The PKC isozyme specific antibody detected a protein band of approximately $80 \mathrm{kDa}$, whereas the actin antibody detected a protein band of about 43 $\mathrm{kDa}$. 
Figure 2. Semi quantitative analysis of the densitometry derived from the Western blot to reveal the array of PKC isozymes expressed in the $\mathrm{d}-4$ and $\mathrm{d}-10$ bovine CL. The $\mathrm{y}$-axis shows the ratio of the optical density (o.d.) for each PKC isozyme corrected by the detected o.d. for its corresponding actin. The data is shown as mean \pm SEM, values with differing letters denote statistically significant differences by two way ANOVA followed by the Tukey-Krame Honesty Significant Difference $(\mathrm{P}<0.01)$.

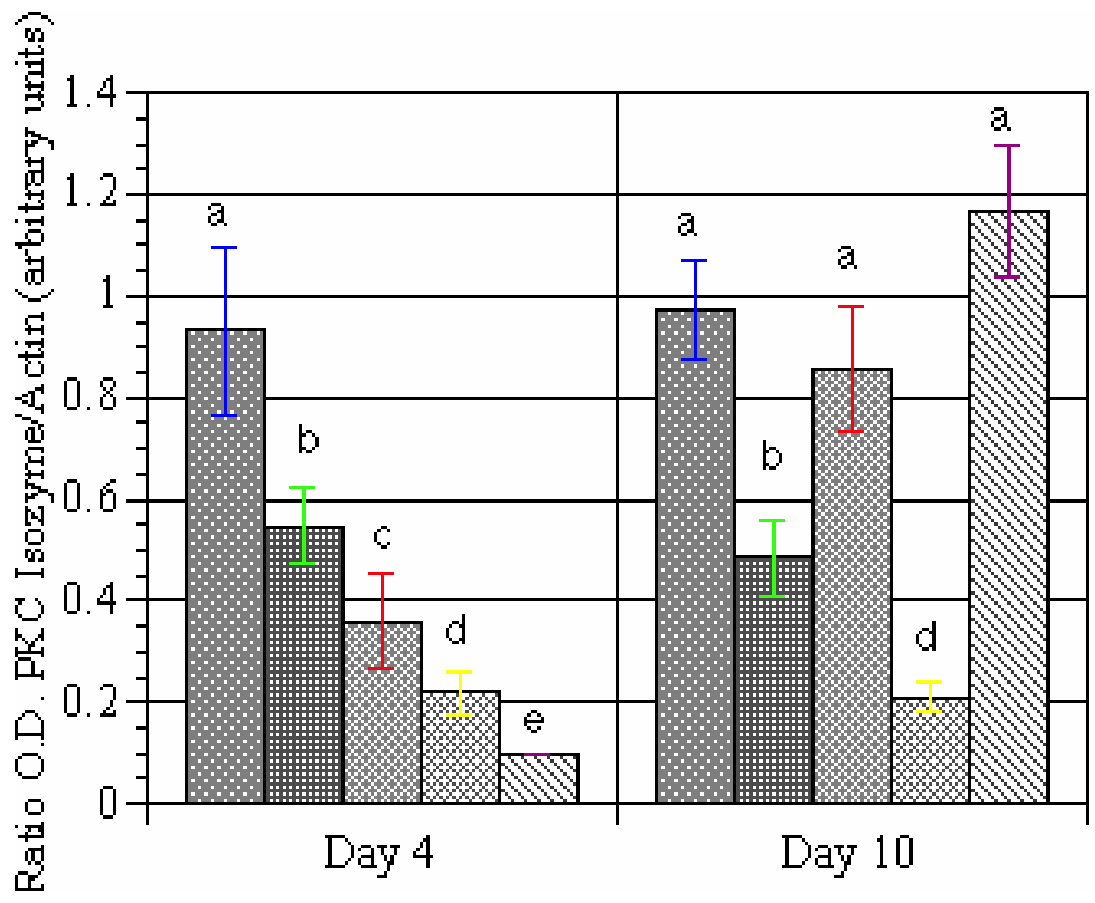

Alpha/Actin

Beta I/Actin

Beta IV/Actin

Mu/Actin

Epsilon/Actin 

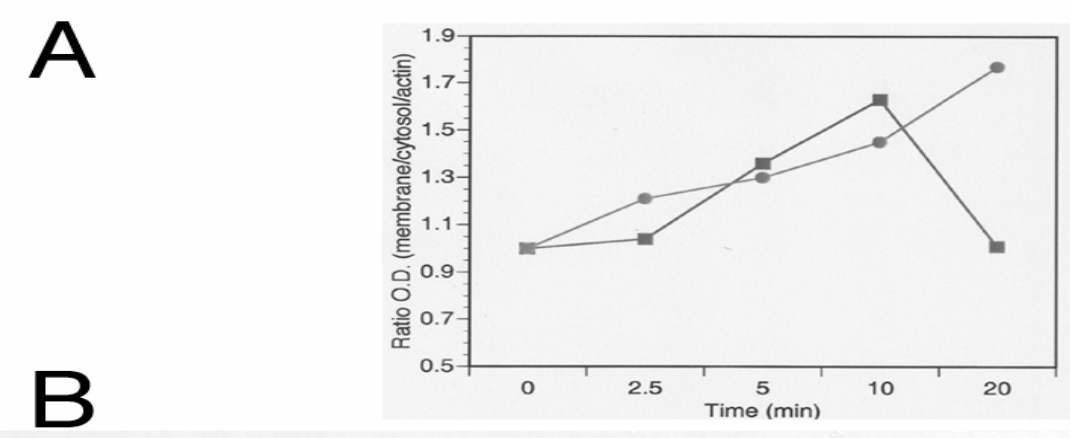

\section{Membrane}

\section{Cytosol}

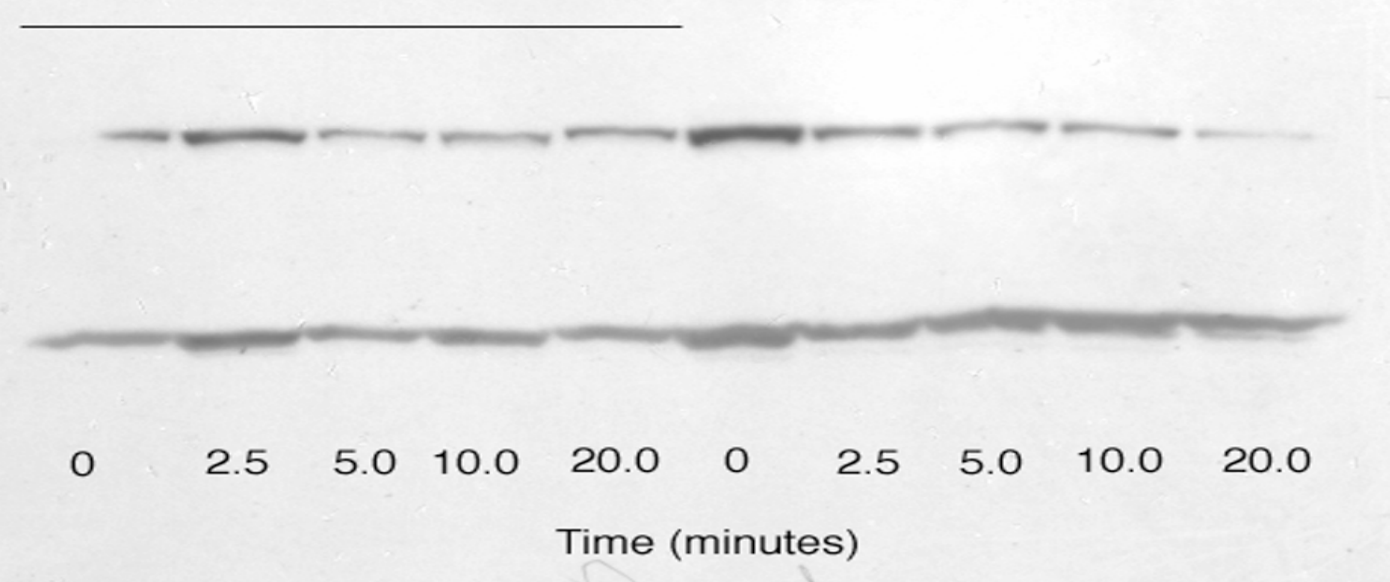

80

42

Figure 3. Semi quantitative Western blot analysis of the time course distribution of PKC $\alpha$ in the cytosolic and membrane protein fractions isolated from one d-10 CL. Luteal tissue fragments were incubated in MEM-Hepes or MEM-Hepes containing $10 \mathrm{nM}$ $\mathrm{PGF}_{2 \alpha}$ for the indicated times. Panel A depicts the ratio of the optical density (o.d.) detected for the PKC isozyme corrected by the o.d. detected for actin. Panel B shows the representative Western blot used for the semi quantitative data shown in panel A. 


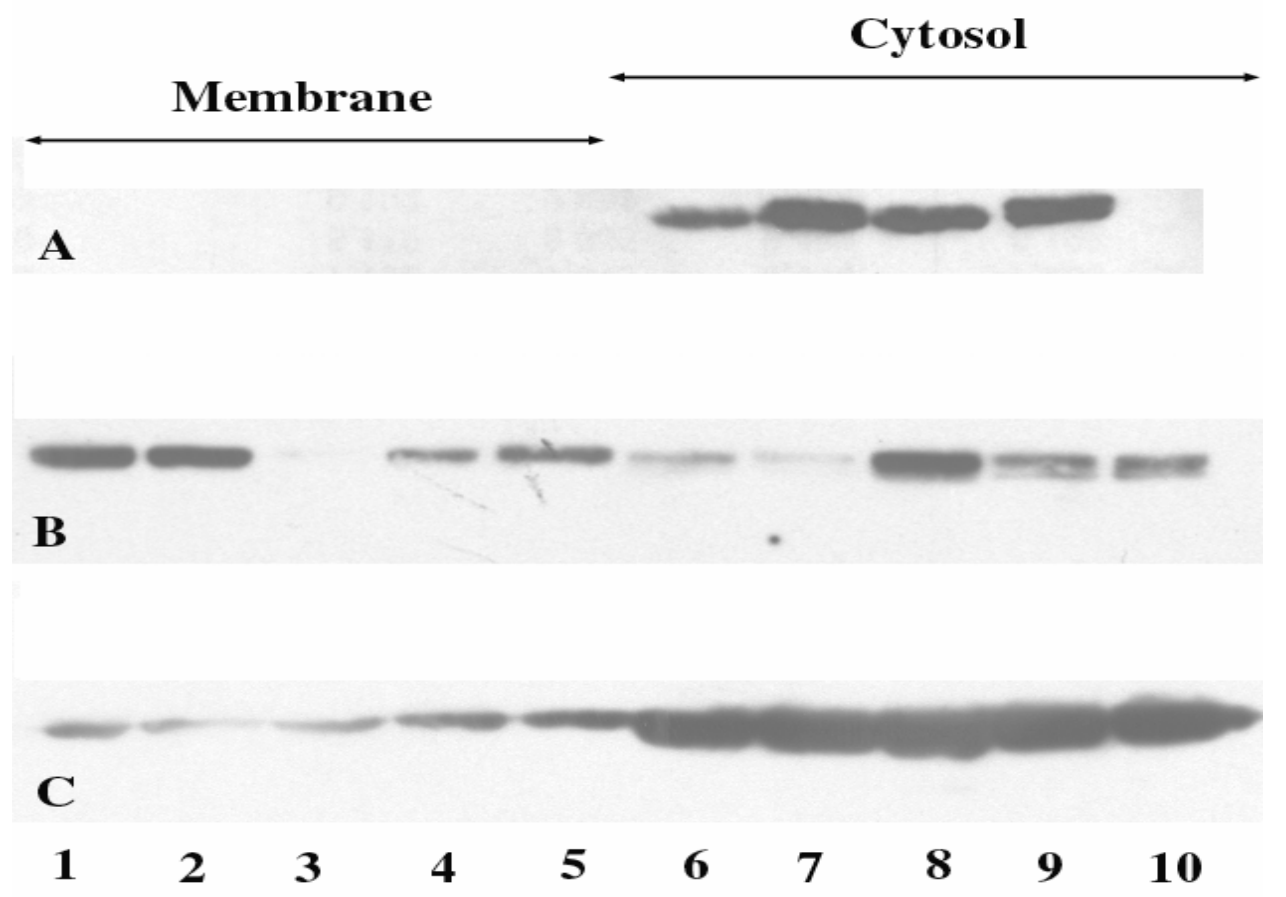

Figure 4. Representative Western blot demonstrating PKC $\alpha$ in translocation in the d-10 luteal tissue after stimulation with $\mathrm{PGF}_{2 \alpha}$. Panel A reveals the exclusive cytoplasmic localization of the PKC $\alpha$ when the tissue was incubated with the control media, MEMHepes. Panel B demonstrates that after 10 minutes incubation of the luteal tissue with $\mathrm{PGF}_{2 \alpha}$ induced the appearance of PKC $\alpha$ in the membrane fraction. Panel $\mathrm{C}$ reveals the amount of actin associated with each sample of blot in panel A. 
TABLE 1. Summary of the PGF2 $\alpha$-stimulated cellular redistribution of the PKC isozymes

\begin{tabular}{|c|c|c|c|c|}
\hline & Media & & PGF $2 \alpha$ & \\
\hline & $\begin{array}{l}\text { Cytoplasm } \\
\text { (Ratio C/A) }\end{array}$ & $\begin{array}{l}\text { Membrane } \\
\text { (Ratio M/A) }\end{array}$ & $\begin{array}{l}\text { Cytoplasm } \\
\text { (Ratio C/A) }\end{array}$ & $\begin{array}{l}\text { Membrane } \\
\text { (Ratio M/A) }\end{array}$ \\
\hline \multicolumn{5}{|c|}{ Day 4} \\
\hline $\operatorname{PKC} \alpha$ & $0.95 \pm 0.06$ & - & $0.92 \pm 0.03$ & $1.11 \pm 0.05$ \\
\hline PKC $\beta$ I & $0.59 \pm 0.02$ & - & $0.54 \pm 0.1$ & $0.30 \pm 0.08$ \\
\hline $\mathrm{PKC} \beta$ II & $0.35 \pm 0.06$ & - & $0.30 \pm 0.08$ & $0.37 \pm 0.1$ \\
\hline $\mathrm{PKC} \varepsilon$ & - & - & - & - \\
\hline \multicolumn{5}{|l|}{ PKC $\mu$} \\
\hline & - & - & - & - \\
\hline \multicolumn{5}{|c|}{ Day 10} \\
\hline $\mathrm{PKC} \alpha$ & $0.78 \pm 0.09$ & - & $0.79 \pm 0.04$ & $1.15 \pm 0.1$ \\
\hline $\mathrm{PKC} \beta \mathrm{I}$ & $0.68 \pm 0.03$ & $0.69 \pm 0.02$ & $0.81 \pm 0.04$ & $1.18 \pm 0.06$ \\
\hline PKC $\beta$ II & $0.69 \pm 0.02$ & $0.95 \pm 0.06$ & $1.15 \pm 0.02$ & $1.45 \pm 0.05$ \\
\hline $\mathrm{PKC} \varepsilon$ & $0.61 \pm 0.02$ & - & $0.79 \pm 0.03$ & $0.71 \pm 0.03$ \\
\hline $\mathrm{PKC} \mu$ & - & - & - & - \\
\hline
\end{tabular}




\section{Chapter IV: Effects of Selective Protein Kinase C Isozymes in Prostaglandin $F_{2 \alpha}$ - induced $\mathrm{Ca}^{2+}$ Signaling and Luteinizing Hormone-Induce Progesterone Accumulation in the Mid-Phase Bovine Corpus Luteum}

\section{Introduction}

Prostaglandin $\mathrm{F}_{2 \alpha}\left(\mathrm{PGF}_{2 \alpha}\right)$ is generally recognized as the major luteolytic factor in domestic ruminants [Niswender GD et al, 1994]. In bovine and ovine corpora lutea, the luteolytic action of $\mathrm{PGF}_{2 \alpha}$ has been shown to be mediated by G-protein-coupled receptors that activate the phospholipase C (PLC) effector system [Davis JS et al, 1987]. Indeed, stimulation of luteal cells with $\mathrm{PGF}_{2 \alpha}$ leads to the rapid accumulation of inositol 1,4,5trisphosphate $\left(\mathrm{IP}_{3}\right)$ and 1,2-diacylglycerol (DAG). When it binds to its receptor in the endoplasmic reticulum, $\mathrm{IP}_{3}$ stimulates an increase in the concentration of cytoplasmic calcium ions $\left(\left[\mathrm{Ca}^{2+}\right]_{\mathrm{i}}\right)$ [Davis JS et al, 1987; Putney JW Jr, 1986; Putney JW Jr, 1990]. The increases in $\left[\mathrm{Ca}^{2+}\right]_{i}$ and DAG result in activation of another intracellular mediator of hormone actions, protein kinase $\mathrm{C}$ (PKC). Thus, PKC and calcium are two major intracellular mediators of the luteolytic actions of $\mathrm{PGF}_{2 \alpha}$ [Davis JS et al, 1987; Wiltbank MC et al, 1991].

PKC is a family of serine-threonine kinases that exist as at least 11 closely related isozymes. They are classified into four categories: conventional (designated as $\alpha, \beta I$, ßII, and $\gamma$ ), novel ( $\delta, \varepsilon, \psi, \eta$ and $\nu$ ), atypical ( $\zeta$ and $\lambda$ ), and PKC $\mu$. The cofactors required for activation of the isozymes differ in each category. Conventional isozymes are calcium-dependent, whereas novel isoforms are not. However, both conventional and novel isozymes require DAG and phosphatidyl-serine for their activation [Newton AC, 1995; Mellor H et al, 1998; Mochly-Rosen D et al, 1998]. Moreover, the atypical PKC isozymes are calcium- and DAG-independent [Newton AC, 1995; Mellor H et al, 1998; Mochly-Rosen D et al, 1998]. A hallmark of PKC activation is its redistribution from one cytoplasmic compartment to another [Kraft AS et al, 1983]. Translocation of PKCs is mediated by isozyme-specific anchoring proteins termed RACKs [Mochly-Rosen D, 1995; Mochly-Rosen D et al, 1991]. RACK binding results in anchoring the activated PKC isozyme near its substrate. Phosphorylation of the PKC substrate then leads to isozyme-specific physiological responses. Thus, the subcellular localization and 
functional specificity of activated PKC isozymes depend on their binding to their corresponding RACK [Newton AC, 1995; Mochly-Rosen D et al, 1998; Pauken CM et al, 2000; Akita Y, 2002].

In addition to the $\mathrm{Ca}^{2+}$ requirement for activation of conventional PKC isozymes, various isozymes are themselves involved in regulating agonist-induced $\mathrm{Ca}^{2+}$ signaling in different cell types [Smeets RL et al, 1998; Song SK et al, 1998; Petersen CCH et al, 1994; Bissonnette M et al, 1994; Xu Y et al, 1995; Gronroos E et al, 1996; Crooke ST et al, 1989; Vegesna RV et al, 1998]. For example, PKC-epsilon (PKC \&) is necessary for initiation of leukotriene D4-induced $\mathrm{Ca}^{2+}$ signaling in intestinal epithelial cells [Thodeti $\mathrm{CK}$ et al, 2001]. And in neurons, $\mathrm{PKC} \varepsilon$ regulates $\mathrm{Ca}^{2+}$ signaling by modulating N-type $\mathrm{Ca}^{2+}$ channels [Maeno-Hikichi $\mathrm{Y}$ et al, 2003]. Additional actions of PKC on $\mathrm{Ca}^{2+}$ signaling include reducing intracellular calcium storage capacity and augmenting $\mathrm{Ca}^{2+}$ entry with submaximal intracellular calcium pool depletion [Carla M et al, 1996], mediation of a negative feedback loop involved in inhibition of $\mathrm{IP}_{3}$ production with a consequent constant frequency of $\left[\mathrm{Ca}^{2+}\right]_{i}$ oscillations in mouse lachrymal acinar cells [Bird GS et al, 1993], PKC-stimulated modulation of $\mathrm{IP}_{3} / \mathrm{Ca}^{2+}$ signaling in the submandibular duct cell line A253 [Sugita $\mathrm{K}$ et al, 1999], and PKC activation of capacitative calcium entry in an insulin-secreting cell line RINm5F [Bode HP et al, 1994].

Sensitivity of the corpus luteum (CL) to luteolytic actions of $\mathrm{PGF}_{2 \alpha}$ is affected by luteal development. The CL of the early estrous cycle (Days 1-5) is resistant to the luteolytic action of a dose of $\mathrm{PGF}_{2 \alpha}$ that induces luteolysis in the mid to late CL (Days 815). The mechanisms responsible for this insensitivity are not fully understood but it is likely that several mechanisms are integrated in diverse populations of luteal cells. A recent study [Sen A et al, 2004] demonstrated that the array of PKC isozymes expressed in the bovine CL includes $\alpha, \beta I, B I I, \varepsilon$, and $\mu$. Moreover, PKC was differentially expressed according to the developmental stage of the CL [Sen A et al, 2004]. Based on these observations, we proposed that differential expression of PKC $\varepsilon$ could contribute to the cellular mechanisms responsible for the relative insensitivity of the early $\mathrm{CL}$ to the luteolytic actions of $\mathrm{PGF}_{2 \alpha}$ [Sen A et al, 2004]. However, specific roles of specific PKC isozymes in CL physiology have received little attention to date. 
In this study, a PKC $\varepsilon$-specific inhibitor peptide ( $\varepsilon \mathrm{V} 1-2)$ was used to investigate the role of this isozyme in previously well-characterized luteolytic actions of $\mathrm{PGF}_{2 \alpha}$. This inhibitor is 6-8 amino acids long and is derived from the RACK-binding site for PKC $\varepsilon$. Binding of the inhibitor peptide to PKC $\varepsilon$-specific RACK blocks binding of the activated isozyme to RACK, thereby preventing its translocation and its physiological response [Johnson JA et al, 1996; Koponen S et al, 2003; Gray MO et al, 1997]. Effective delivery of inhibitor into cells is achieved by means of peptide-delivery technology [Derossi D et al, 1994; The'odore L et al, 1995; Vives E et al, 1997]. Once in the cell, the bond linking the inhibitor to a carrier peptide is cleaved, releasing the free inhibitory peptide. The use of this technology in combination with saponin-mediated cell permeabilization facilitates cellular entry of inhibitory peptides [Derossi D et al, 1994; The'odore L et al, 1995; Vives E et al, 1997]. The specificity of these isozyme-selective peptides has been fully characterized in a variety of cell types, including intestinal epithelial cells [Chang Q et al, 2003], pancreatic cells [Yedovitzky M et al, 1997], esophageal smooth cells [Sohn UD et al, 1997], and vascular smooth muscle cells [Lee YH et al, 1999].

The aim of this study was to use a PKC $\varepsilon$-specific inhibitor to investigate the role of this isozyme in two luteal end points: 1) a $\mathrm{PGF}_{2 \alpha}$-induced rise in $\left[\mathrm{Ca}^{2+}\right]_{\mathrm{i}}$, and 2) a $\mathrm{PGF}_{2 \alpha}$-induced decline in basal and LH-induced progesterone accumulation. The potential role of PKC $\varepsilon$ in these aspects of luteal physiology was investigated during the early luteal and mid-luteal phases, developmental stages at which PKC $\varepsilon$ is known to be expressed at low and high concentrations, respectively. Based on the results, it is suggested that PKC \& plays an important role in the ability of $\mathrm{PGF}_{2 \alpha}$ to induce these two effects on the midphase bovine CL.

\section{Materials and methods}

\section{Tissue Collection}

Nonlactating beef cows were observed visually for estrus twice daily at approximately 12 -h intervals for a minimum of $30 \mathrm{~min}$ per observation. The day when

standing estrus was observed was designated as Day 0 [Casida LE, 1959]. After two cycles, four Day-4 and seven Day-10 corpora lutea were collected by ovariectomy (Day 
4) or blunt dissection (Day 10) via supravaginal incision under epidural anesthesia. For the epidural anesthesia, 6-9 $\mathrm{ml}$ of $2 \%$ lidocaine was administered for cows weighing 450-700 kg (Butler Company, Columbus, OH). The CL or ovary was collected into icecold PBS pH 7.4 and transported to the laboratory within 15-30 min after collection. The West Virginia University Animal Care and Use Committee reviewed and approved the protocol for the tissue collection (Animal Care and Use Committee 01-0809).

\section{Luteal Cell Dispersion and Purification}

In the laboratory, the corpora lutea were dissected free of connective tissue, weighed, placed in cell-dispersion medium (CDM; M-199 containing 0.1\% BSA, $25 \mathrm{mM}$ Hepes, and $100 \mathrm{U} / \mathrm{ml}$ fungicide), and cut into small (about $1 \mathrm{~mm} 3$ ) fragments. The tissue fragments were washed twice with $\mathrm{CDM}$ and placed into $5 \mathrm{ml}$ of fresh CDM containing collagenase type IV (420 U ml g of tissue; Gibco, Invitrogen Life Technologies, Carlsbad, CA). The details of the tissue dissociation protocol have been previously published [Choudhary E et al, 2005]. Luteal endothelial cells were separated by a procedure previously described [Mamluk R et al, 1998; Levy N et al, 2001]. Briefly, magnetic Tosylactivated beads (Dynal Biotech, Lake Success, NY) were coated with BS1 lectin $(0.15 \mathrm{mg} / \mathrm{ml}$; Vector Laboratories, Burlingame, CA, ) for $24 \mathrm{~h}$ at room temperature. The beads were washed and stored at $4{ }^{\circ} \mathrm{C}$ until use. Dispersed luteal cells were suspended in 1\% PBS, mixed with beads at a bead:cell ratio of 1:3, and placed for $25 \mathrm{~min}$ at $4^{\circ} \mathrm{C}$ on a rocking platform. The bead-adherent cells were washed with $1 \%$ PBS and concentrated using a magnetic particle concentrator (Dynal Biotech). Both BS-1adhering (endothelial cells) and nonadherent cells (steroidogenic-enriched luteal cells) were collected by this procedure. In this study, the cell population we designated as steroidogenic those cells did not have beads attached, but they represent a heterogeneous population of cells that include fibroblasts, pericytes, lymphoid, and any endothelial cells not removed by our separation procedure. Cell viability and density were determined using Tryptan Blue-exclusion and a hemacytometer; luteal cell viability was greater than $96 \%$. 


\section{Single-Cell Calcium Measurements}

The cell density of the enriched populations of luteal cells was adjusted to $1 \times 10^{5}$ cells/ml by adding bicarbonate-buffered medium 199 (M199) supplemented with 5.0\% fetal calf serum (FCS). This initial concentration of FCS in M199 allowed luteal cell attachment to microscope slides. An $80-\mu 1$ aliquot of the cell suspension was applied to a Cunningham chamber constructed on poly-L-lysine-coated microscope slides [Flores JA et al, 1998; Flores JA et al, 1990; Flores JA et al, 1991]. The Cunningham chambers were maintained overnight in a tissue culture incubator $\left(37^{\circ} \mathrm{C}, 95 \%\right.$ air-5\% CO2). PolyL-lysine, M199, FCS, and penicillin-streptomycin were from Life Technologies (Grand Island, NY).

\section{Experiment 1: Potential Role for PKC $\varepsilon$ in $\mathrm{PGF}_{2 \alpha^{-}}$-Initiated $\mathrm{Ca}^{2+}$ Signaling}

In this experiment, we tested the involvement of $\mathrm{PKC} \varepsilon$ in the $\mathrm{PGF}_{2 \alpha}$-induced calcium signaling in luteal steroidogenic cells isolated from Day 4 and Day 10 corpora lutea. Steroidogenic cells cultured overnight in Cunningham chambers were randomly divided into three groups and treated as follows: 1) M199 containing $50 \mu \mathrm{g} / \mathrm{ml}$ saponin (Sigma, St. Louis MO); 2) M199 containing $50 \mu \mathrm{g} / \mathrm{ml}$ saponin and $1 \mu \mathrm{M}$ PKC-specific inhibitor, V1-2 (MTA, Stanford, CA); or 3) M199 containing $50 \mu \mathrm{g} / \mathrm{ml}$ saponin and 1 $\mu \mathrm{M}$ PKC conventional-specific inhibitor, betaC 2, 4 (MTA) for $1 \mathrm{~h}$ at $37^{\circ} \mathrm{C}$. After saponin permeabilization and inhibitory peptide-delivery, the cells were prepared for single-cell calcium measurements. The tissue culture medium in this portion of the experiment consisted of $127 \mathrm{mM} \mathrm{NaCl}, 5 \mathrm{mM} \mathrm{KCI}, 1.8 \mathrm{mM} \mathrm{CaCl} 2,2 \mathrm{mM} \mathrm{MgCl} 2,5 \mathrm{mM}$ KHPO4, 5 mM NaHCO3, 10 mM Hepes, 10 mM glucose, and 0.1\% BSA pH 7.4. Luteal cells were loaded with $1 \mu \mathrm{M}$ fura-2/AM (Calbiochem, San Diego, CA) in experimental medium (without hormones) for $20 \mathrm{~min}$ at $37^{\circ} \mathrm{C}$. The cells were washed with experimental medium and incubated for an additional $20 \mathrm{~min}$ at $37^{\circ} \mathrm{C}$ to allow cytoplasmic de-esterification of the fura-2/ AM dye.

After dye loading, the Cunningham chamber was placed on the stage of an Olympus PROVIS AX70 microscope (Olympus America Inc., Melville, NY) equipped for epifluorescence microscopy. All experiments were performed at room temperature 
$\left(22-25^{\circ} \mathrm{C}\right)$. The details for microscope set up for dual wavelength ratio capture and analysis of intracellular calcium concentration have been previously published [Choudhary E et al, 2005]. For further analysis, the cell responses were represented as changes in the 340:380 nm fluorescence ratios over time. Changes in fluorescence ratio at these two wavelengths have been demonstrated to be due to changes in $\left[\mathrm{Ca}^{2+}\right]_{\mathrm{i}}$. Microscopic fields were selected using a bright field image with a 20x objective lens with which cell size and morphology could be determined. Both steroidogenic cells were round and contained lipid droplets; steroidogenic cells identified as large (LLCs) had a diameter of $20 \mu \mathrm{m}$ or more, while the small steroidogenic cells (SLCs) measured $15 \mu \mathrm{m}$ or less (Fig. 1). This field selection procedure allowed recording two to three cells per slide. The identified cells were then challenged with experimental medium alone (control) or with experimental medium containing $1000 \mathrm{ng} / \mathrm{ml} \mathrm{PGF}_{2 \alpha}$. This concentration of $\mathrm{PGF}_{2 \alpha}$ was selected because a previous experiment had demonstrated that in the early $\mathrm{CL}$, lower concentrations of $\mathrm{PGF}_{2 \alpha}$ were not effective in eliciting maximal responses in these cells [Choudhary E et al, 2005].

Experiment 2: Potential Role for PKC $\varepsilon$ in $\mathrm{PGF}_{2 \alpha}$-Induced Inhibition of Basal and LHStimulated Progesterone Accumulation

This experiment was designed to test the involvement of PKC $\varepsilon$ in $\mathrm{PGF}_{2 \alpha}$-induced inhibition of basal and LH-stimulated progesterone (P4) secretion by Day 4 and Day 10 steroidogenic cells. After luteal cell dispersion and purification, steroidogenic cells $(1 \mathrm{x}$ $10^{5}$ cells) were added in small aliquots $(100 \mu \mathrm{l})$ to wells (Corning $35-\mathrm{mm}$ cell culture clusters; Fisher Scientific Company, Blawnox, PA), containing the following: 1) $1 \mathrm{ml}$

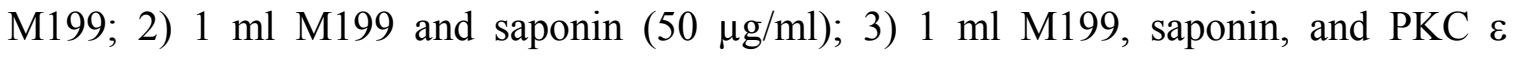
inhibitor $(1 \mu \mathrm{M})$; 4) $1 \mathrm{ml} \mathrm{M} 199$, saponin, and conventional PKC inhibitor $(1 \mu \mathrm{M})$; 5) 1 ml M199, saponin, and $\left.\mathrm{PGF}_{2 \alpha}(1000 \mathrm{ng} / \mathrm{ml}) ; 6\right) 1 \mathrm{ml}$ M199, saponin, $\mathrm{PGF}_{2 \alpha}$, and PKC $\varepsilon$

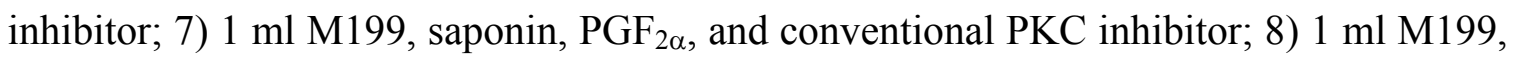
saponin, and LH (100 ng/ml); 9) $1 \mathrm{ml} \mathrm{M199,} \mathrm{saponin,} \mathrm{LH,} \mathrm{and} \mathrm{PKC} \varepsilon$ inhibitor; 10) $1 \mathrm{ml}$ M199, saponin, LH, and conventional PKC inhibitor; 11) saponin, LH, and $\mathrm{PGF}_{2 \alpha}$; 12) 1 ml M199, saponin, LH, $\mathrm{PGF}_{2 \alpha}$, and PKC $\varepsilon$ inhibitor; and 13) $1 \mathrm{ml}$ M199, saponin, LH, 
$\mathrm{PGF}_{2 \alpha}$, and conventional PKC inhibitor. Each treatment was applied in duplicate to cells from each CL. The cells were incubated for $4 \mathrm{~h}$ at $37^{\circ} \mathrm{C}$ (95\% air, 5\% CO2). After incubation, medium free of cells was removed from each well and stored frozen until assayed for measurement of P4. Measurements of P4 in the culture media were performed using a radioimmunoassay (RIA) as previously described [Sheffel CE et al, 1982]. The standard curve for this RIA ranged from $10 \mathrm{pg} / \mathrm{ml}$ to $800 \mathrm{pg} / \mathrm{ml}$, and the intraassay and interassay coefficients of variation were $9.2 \%$ and $12.8 \%$, respectively.

\section{Statistical Analysis}

Statistical analyses were performed using the JMP 3.0, a statistical software program from Statistical Analysis Systems [Cary NC, 1994]. Data are presented as means \pm SEM for all experiments. The data for fold increase (340:380 $\mathrm{nm}$ ratio) were arcsine transformed to meet the assumptions of normality, and for presentation, all the means were back-transformed accordingly. Three-way analysis of variance (ANOVA) followed by a Tukey-Kramer honestly significant difference test was used to determine statistical significance of fold increase in $\left[\mathrm{Ca}^{2+}\right]_{i}$ between PKC inhibitor-treated cells and untreated cells (control). The P4 data were log-transformed to meet the assumptions of normality, and for presentation, all the means were back-transformed accordingly. One-way ANOVA followed by a Tukey-Kramer honestly significant difference test was used to determine statistical significance differences in $\mathrm{P} 4$ accumulation. A value of $P<0.05$ was considered significant.

\section{Results}

Experiment 1

Morphological characteristics of the LLCs and SLCs identified from steroidogenic-enriched cell populations are shown in Figure 1; SLCs had a diameter $<20$ $\mu \mathrm{m}$, LLCs typically had a diameter $>20 \mu \mathrm{m}$. Using the $20 \mathrm{x}$ objective lens typically allowed recording two or three cells per slide. For each cell, any increase in fluorescence ratio that exceeded basal values before stimulation was considered a response. To demonstrate agonist-specificity of the responses, both LLCs and SLCs were stimulated with vehicle media alone. Representative traces of Day 10 LLCs stimulated with vehicle 
media, $\mathrm{PGF}_{2 \alpha}$ in the absence or presence of a PKC $\varepsilon$ inhibitor are shown in Figure 2. In Day 10 cells, only 5 of 70 LLCs (7\%) and 10 of 80 SLCs (12\%) responded to vehicle, and the amplitude of this response was only 1.2-fold \pm 0.2 -fold in LLCs and 0.8 -fold \pm 0.5 -fold in SLCs over basal values before stimulation. Similarly, in cells from Day 4 corpora lutea, no responders were observed of 80 LLCs tested, while 12 of 90 SLCs (13\%) responded with an amplitude of 0.8 -fold \pm 0.3 -fold above the basal level when treated with vehicle media alone.

The concentration of $\mathrm{PGF}_{2 \alpha}$ used $(1000 \mathrm{ng} / \mathrm{ml})$ was effective $(P<0.05)$ in eliciting agonist-specific increases in $\left[\mathrm{Ca}^{2+}\right]_{\mathrm{i}}$ in LLCs and SLCs (Fig. 3). Representative traces of these $\mathrm{PGF}_{2 \alpha}$-induced $\mathrm{Ca}^{2+}$ responses in LLCs and SLCs collected from Day 4 and Day 10 corpora lutea are shown in Figures 3 and 4. Most of the elicited responses were observed within $45 \mathrm{sec}$, but there was variability in this aspect of the response. In general, CL development (Day 10 vs. Day 4, compare control LLCs in Figures 3 and 4) and cell type (LLCs vs. SLCs, compare control LLCs with control SLCs in Figures 3 and 4) had significant $(P<0.001)$ effects on the fold increase in the $\mathrm{PGF}_{2 \alpha}$-induced rise in $\left[\mathrm{Ca}^{2+}\right]$ i. This is shown clearly in Figure 5, in which the total analysis of the elicited responses is presented.

The fold increase in the $\mathrm{PGF}_{2 \alpha}$-induced rise in $\left[\mathrm{Ca}^{2+}\right]_{\mathrm{i}}$ in Day 4 LLCs was significantly lower than in Day 10 LLCs (Fig. $5 ; 4.0 \pm 0.6, \mathrm{n}=116$ vs. $21.3 \pm 2.3, \mathrm{n}=$ 110). Similarly, the fold increase in the $\mathrm{PGF}_{2 \alpha}$-induced rise in $\left[\mathrm{Ca}^{2+}\right]_{\mathrm{i}}$ in Day 4 SLCs was lower than in Day 10 SLCs (Fig. 5; $1.6 \pm 0.2, \mathrm{n}=198$ vs. $2.7 \pm 0.1, \mathrm{n}=95$ ). On both developmental days examined, the fold increase of the $\mathrm{PGF}_{2 \alpha}$-induced rise in $\left[\mathrm{Ca}^{2+}\right]_{\mathrm{i}}$ was lower in SLCs than in LLCs (Fig. 5). Although the PGF $_{2 \alpha}$-induced fold increase in $\left[\mathrm{Ca}^{2+}\right]_{\mathrm{i}}$ in Day 4 SLCs was small $(1.56 \pm 0.2)$, it was specific and greater $(P<0.05)$ than when SLCs were challenged with vehicle alone $(0.8 \pm 0.3)$.

The PKC $\varepsilon$-specific inhibitor had a significant negative effect on the $\mathrm{PGF}_{2 \alpha}$ induced rise in $\left[\mathrm{Ca}^{2+}\right]_{\mathrm{i}}$ in both Day 10 LLCs and SLCs (see lower panels in Fig. 4). The presence of the $\mathrm{PKC} \varepsilon$ inhibitor drastically reduced the $\mathrm{PGF}_{2 \alpha}$-elicited responses to $3.5 \pm$ $0.3(\mathrm{n}=217)$ and $1.3 \pm 0.1(\mathrm{n}=205)$ in Day 10 LLCs and SLCs, respectively (Fig. 5). In contrast, treatment with the $\mathrm{PKC} \varepsilon$ inhibitor had no effect on the $\mathrm{PGF}_{2 \alpha}$-induced rise in 
$\left[\mathrm{Ca}^{2+}\right]_{\mathrm{i}}$ in Day 4 LLCs and SLCs (Fig. 5). In Day 10 cells, a response of great amplitude could still be elicited in inhibitor-treated cells by stimulating them with the calcium ionophore, A23187 (1 $\mu \mathrm{M}$; Fig. 1, lower panel). This result provides a strong argument in favor of the interpretation that the decrease in the $\mathrm{PGF}_{2 \alpha}$-induced response was indeed due to the specific effect of the inhibitor on blocking PKC $\varepsilon$ activation and function.

To assess the specificity of $\mathrm{PKC} \varepsilon$ involvement in affecting the $\mathrm{PGF}_{2 \alpha}$-induced calcium signaling, we examined the effect of a PKC inhibitor for all conventional PKCs, beta C2,4. Conventional PKC inhibitor-treated Day 10 LLCs and SLCs responded similarly to control cells without inhibitor (Fig. 5).

\section{Experiment 2}

To further analyze the involvement of PKC $\varepsilon$ in the luteolytic actions of $\mathrm{PGF}_{2 \alpha}$, we measured basal and LH-induced P4 accumulation in the presence and absence of a PKC $\varepsilon$-specific inhibitor. Progesterone data from treatments 2, 5, 8, and 11-13 (Materials and Methods) from cells isolated from Day 10 corpora lutea are shown in Figure 6. No significant differences were observed due to treatment for groups $1,3,4,6,7,9$, and 10 described in Materials and Methods; therefore, the data corresponding to those groups are not shown.

In Day 4 isolated cells, the basal amount of P4 accumulated in cultures was $14.7 \pm$ $4.3 \mathrm{ng} \mathrm{ml} 4 \mathrm{~h}$, and none of the treatments had an effect.

Basal P4 accumulation in cultures of Day 10 steroidogenic cells was three times higher than in Day 4 isolated cells $(45.3 \pm 10.8$ vs. $14.7 \pm 4.3 \mathrm{ng} \mathrm{ml} 4 \mathrm{~h}$, respectively; $P=$ 0.03). $\mathrm{PGF}_{2 \alpha}$ had no effect $(P=0.27)$ on basal P4 accumulation (Fig. 6). However, LH $(100 \mathrm{ng} / \mathrm{ml})$ induced a significant $(P=0.01)$ increase in $\mathrm{P} 4$ accumulation (more than a 3fold increase) over that observed under basal conditions (Fig. 6). And $\mathrm{PGF}_{2 \alpha}$ significantly $(P=0.01)$ decreased this effect of $\mathrm{LH}$, reducing it to values below basal conditions (Fig. 6). Progesterone accumulation in luteal cells incubated with $\mathrm{LH}, \mathrm{PGF}_{2 \alpha}$, and the conventional $\mathrm{PKC}$ inhibitor was significantly greater than in cells incubated with $\mathrm{PGF}_{2 \alpha}$ and $\mathrm{LH}$, although not quite as much as incubations with $\mathrm{LH}, \mathrm{PGF}_{2 \alpha}$, and the PKC $\varepsilon$ inhibitor (Fig. 6, $P=0.02$ ). 


\section{Discussion}

This study provides evidence for a differential and specific PKC isozyme function on well-characterized actions of $\mathrm{PGF}_{2 \alpha}$ in bovine luteal physiology. The results indicate that $\mathrm{PKC} \varepsilon$, an isozyme previously shown to be differentially expressed in Day 10 corpora lutea, has a regulatory role in the $\mathrm{PGF}_{2 \alpha}$-induced $\mathrm{Ca}^{2+}$ signaling, and that this in turn, has consequences on the ability of $\mathrm{PGF}_{2 \alpha}$ to inhibit LH-stimulated P4 synthesis at this developmental stage. In other tissues, it is well established that PKC isozymes have very specific functions [Mischak $\mathrm{H}$ et al, 1993; Borner $\mathrm{C}$ et al, 1995], but in the CL, the biological functions of individual PKC isoforms had not yet been elucidated.

Our single-cell calcium experiments demonstrate that both LLCs and SLCs from Day 10 corpora lutea respond to $\mathrm{PGF}_{2 \alpha}$ with a rise in $\left[\mathrm{Ca}^{2+}\right]_{\mathrm{i}}$ of greater amplitude than cells from Day 4 corpora lutea. A similar observation was recently reported by Choudhary et al. [Choudhary E et al, 2005], who studied the full dose-response of LLCs and SLCs to $\mathrm{PGF}_{2 \alpha}$ as a function of luteal development. Based on this observation, it is strongly suggested that a developmental difference exists in the ability of $\mathrm{PGF}_{2 \alpha}$ to increase the $\left[\mathrm{Ca}^{2+}\right]_{\mathrm{i}}$ in both steroidogenic cell types of the bovine CL. That both cell types respond to $\mathrm{PGF}_{2 \alpha}$ with a rise in $\left[\mathrm{Ca}^{2+}\right]_{\mathrm{i}}$ is consistent with previous reports that both steroidogenic cell types in bovine CL express functional $\mathrm{PGF}_{2 \alpha}$ receptors [Mamluk $\mathrm{R}$ et al, 1998; Alila HW et al, 1988c; Davis JS et al, 1988]. Although $\mathrm{PGF}_{2 \alpha}$ stimulated a rise in $\left[\mathrm{Ca}^{2+}\right]_{\mathrm{i}}$ in LLCs and SLCs at both developmental stages, the elicited response in SLCs was of lower amplitude than the one stimulated in LLCs. This latter observation agrees with the responses elicited by $\mathrm{PGF}_{2 \alpha}$ in LLCs and SLCs in the study by Choudhary et al. [Choudhary E et al, 2005]. In earlier studies [Wiltbank MC et al, 1991; MartinezZaguilan $\mathrm{R}$ et al, 1994; Wegner JA et al, 1991], $\mathrm{PGF}_{2 \alpha}$-induced $\mathrm{Ca}^{2+}$ responses were observed only in LLCs. These difference could be due to species differences between cows and sheep [Wiltbank MC et al, 1991], or to technical differences; a cell population approach was used in one of those studies [54], whereas a single-cell approach was used in the present study for the measurement of $\left[\mathrm{Ca}^{2+}\right]_{\mathrm{i}}$. Differences in regulation of $\left[\mathrm{Ca}^{2+}\right]_{\mathrm{i}}$ homeostasis in LLCs and SLCs have been documented previously [Davis JS et al, 1988; 
Martinez-Zaguilan R et al, 1994; Wegner JA et al, 1991; Wegner JA et al, 1990; Wiltbank MC et al, 1989a] in ovine and bovine corpora lutea. This difference between LLCs and SLCs might explain the differences observed here with regard to the responses elicited by $\mathrm{PGF}_{2 \alpha}$ in LLCs and SLCs. Alila et al. [Alila HW et al, 1990] reported that LH induced a rapid increase in $\left[\mathrm{Ca}^{2+}\right]_{\mathrm{i}}$ that differed both in magnitude and profile between LLCs and SLCs [Alila HW et al, 1990]. Of interest, in the study by Alila et al., it was the SLCs that responded with greater amplitude when stimulated by LH [Alila HW et al, $1990]$.

The PKC $\varepsilon$-specific peptide inhibitor $(\varepsilon \mathrm{V} 1-2)$ used in this study has been demonstrated to block the interaction of PKC $\varepsilon$ with its specific RACK in an effective manner, thereby preventing its translocation and its function [Mochly-Rosen D, 1995; Mochly-Rosen D et al, 1991; Johnson JA et al, 1996; Koponen S et al, 2003; Gray MO et al, 1997]. The interpretation that this was also true in our study is supported by the observation that this inhibitor greatly decreased the amplitude of the $\mathrm{PGF}_{2 \alpha}$-induced $\mathrm{Ca}^{2+}$ response in cells isolated from Day 10 corpora lutea. As expected, in Day 4 corpora lutea in which $\mathrm{PKC} \varepsilon$ is expressed at very low levels, blocking PKC $\varepsilon$ action had no effect on the magnitude of the $\mathrm{PGF}_{2 \alpha}$-induced $\mathrm{Ca}^{2+}$ signal, which was of low amplitude to begin with. Therefore, based on our data it is suggested that PKC $\varepsilon$ might have a regulatory role in the $\mathrm{PGF}_{2 \alpha}$-induced $\mathrm{Ca}^{2+}$ signal in both cell types of the mid-luteal phase corpora lutea. Furthermore, we propose that the developmental difference in the ability of $\mathrm{PGF}_{2 \alpha}$ to increase the $\left[\mathrm{Ca}^{2+}\right]_{\mathrm{i}}$ in both steroidogenic cells types of the Day 4 vs. Day 10 bovine CL is due to the lower expression of PKC $\varepsilon$ at this stage [Sen A et al, 2004].

Of interest, $\mathrm{PGF}_{2 \alpha}$ inhibited LH-stimulated P4 accumulation only in Day 10 luteal cells. This developmental association of the inhibitory action of $\mathrm{PGF}_{2 \alpha}$ agrees with the report by Choudhary et al. [Choudhary E et al, 2005]; however, in that study, the inhibitory actions of $\mathrm{PGF}_{2 \alpha}$ were observed on basal and LH-stimulated P4 accumulation. This discrepancy is most likely due to the permeabilization protocol used in the present study. Although saponin did not have any effect on P4 accumulation on medium-treated control cells (data not shown), the effects of $\mathrm{LH}$ and of $\mathrm{PGF}_{2 \alpha}$ may have been affected due to increased digitonin-mediated permeability. This interpretation is supported by the 
observation that in the present study, LH-stimulated P4 accumulation occurred only in Day 10 luteal cells, whereas Choudhary et al. [Choudhary E et al, 2005] reported an LHstimulated P4 accumulation in Day 4 and Day 10 luteal cells. However, more importantly, the PKC $\varepsilon$ inhibitor greatly reduced the ability of $\mathrm{PGF}_{2 \alpha}$ to inhibit LHstimulated $\mathrm{P} 4$ accumulation. Therefore, at the level of $\mathrm{P} 4$ accumulation, $\mathrm{PKC} \varepsilon$ might also have some regulatory role in the $\mathrm{PGF}_{2 \alpha}$-induced inhibition of $\mathrm{P} 4$ accumulation in cultures of cells isolated from bovine corpora lutea that had acquired luteolytic responsiveness to $\mathrm{PGF}_{2 \alpha}$. Our results do not allow us to discern the precise link between calcium signal and P4 synthesis, but clearly, Figure 6 illustrates that both conventional as well as $\varepsilon$ PKC isozymes are involved in mediating the inhibitory actions of $\mathrm{PGF}_{2 \alpha}$. However, on the basis of calcium and progesterone data presented here, we propose that once the CL has acquired the ability to respond to inhibitory actions of $\mathrm{PGF}_{2 \alpha}, \mathrm{PKC} \varepsilon$ is the isozyme that significantly mediates the $\mathrm{PGF}_{2 \alpha}$-induced calcium signal, and that this in turn, via conventional PKC isozymes, mediates the inhibition by $\mathrm{PGF}_{2 \alpha}$ of LH-stimulated inhibition of P4 accumulation. This interpretation is supported by the observation in experiment 2 in which $\mathrm{P} 4$ accumulation in luteal cells incubated with $\mathrm{LH}, \mathrm{PGF}_{2 \alpha}$, and the conventional PKC inhibitor was significantly higher than in cells incubated with LH and $\mathrm{PGF}_{2 \alpha}$, although not quite as much as with $\mathrm{LH}, \mathrm{PGF}_{2 \alpha}$, and the inhibitor of PKC $\varepsilon$.

The role of PKC in luteal physiology is quite controversial; this may be related to differences in the mechanism used to activate PKC (PMA or $\mathrm{PGF}_{2 \alpha}$ ); incomplete specificity of PKC inhibitors such as H-7, W-7, GF109203X, and staurosporine used in previous studies; the time and dose of agonist used; the tissue used (luteinized granulosal cells, different developmental stages of CL); species differences; and so on. For example, PMA activates all PKC isozymes, whereas hormones such as $\mathrm{PGF}_{2 \alpha}$ may activate only a subset of the PKC array expressed in the cells. Consequently, a variety of studies indicate that PKC stimulates, has no effect, or inhibits P4 synthesis in luteal tissue [Alila HW et al, 1989; Yuan W et al, 1997; Hansel W et al, 1987; Wiltbank MC et al, 1990; Baum MS et al, 1987]. Nevertheless, it is clear that an involvement of PKC in the negative regulation of P4 synthesis in vivo has been demonstrated [McGuire WJ et al, 1994]. Furthermore, Wiltbank et al. demonstrated that $\mathrm{PGF}_{2 \alpha}$ has a direct antisteroidogenic 
effect on both LLCs and SLCs that is mediated through the PKC second-messenger pathway [Wiltbank MC et al, 1989b].

As expected, neither $\mathrm{PGF}_{2 \alpha}$ nor $\mathrm{PKC} \varepsilon$ inhibitor had any effect on $\mathrm{P} 4$ accumulation in Day 4 cultured steroidogenic cells. Earlier studies using the PKC antagonist W-7 have shown an inhibition of both basal and hormone-stimulated P4 synthesis in SLCs and LLCs [Alila HW et al, 1990]. However, we did not observe any effect of $\mathrm{PGF}_{2 \alpha}$, conventional $\mathrm{PKC}$ inhibitor, or PKC $\varepsilon$ inhibitor on basal P4 accumulation in cells from either day, which may be due to differences in experimental procedures as discussed above. Also, our study did not identify whether the effect of $\mathrm{PGF}_{2 \alpha}$ or PKC $\varepsilon$ inhibitor on the LH-stimulated P4 accumulation occurs in both LLCs and SLCs or in LLCs only.

LLCs are suggested to be the potential target of the inhibitory (luteolytic) effect of $\mathrm{PGF}_{2 \alpha}$, whereas SLCs are said to be responsible for the (stimulatory) luteotropic effect of $\mathrm{PGF}_{2 \alpha}$ in the bovine CL [Wiltbank MC et al, 1989b]. However, we observed that $\mathrm{PGF}_{2 \alpha^{-}}$ induced $\mathrm{Ca}^{2+}$ responses were significantly decreased in both LLCs and SLCs when PKC was blocked. The regulatory role of PKC $\varepsilon$ in the $\mathrm{PGF}_{2 \alpha}$-induced $\mathrm{Ca}^{2+}$ signal might have different cellular consequences in LLCs and SLCs. We do not know whether both steroidogenic cell types express the same PKC isozymes. Potentially, both PKC activity and substrate availability could bring about differences in regulation of steroidogenesis by PKC. In ovine steroidogenic cells it has been reported that PKC activity and available protein substrates displayed quantitative and qualitative differences between SLCs and LLCs, and that differences in the regulation of steroidogenesis between these cells might be due to these differences [Hoyer PB et al, 1989]. It has been proposed by Braden et al. that the cytotoxic effects of $\mathrm{PGF}_{2 \alpha}$ may be due to sustained elevation of $\left[\mathrm{Ca}^{2+}\right]_{i}[$ Braden TD et al, 1988]. In this regard, there is evidence for both extracellular and intracellular calcium contributions to the $\mathrm{PGF}_{2 \alpha}$-induced $\mathrm{Ca}^{2+}$ response [Wegner JA et al, 1990]. Our studies do not allow an assessment of whether PKC $\varepsilon$ is modulating the effect of $\mathrm{PGF}_{2 \alpha}$ on intracellular $\mathrm{Ca}^{2+}$ mobilization, $\mathrm{Ca}^{2+}$ influx, or both.

An interesting suggestion in the literature is that there may be an appropriate threshold of $\left[\mathrm{Ca}^{2+}\right]_{i}$ that is required to support P4 synthesis [Wegner JA et al, 1991]. An alteration in the free calcium concentration could be the intracellular second-message that 
mediates the luteolytic actions of $\mathrm{PGF}_{2 \alpha} \quad$ [Martinez-Zaguilan $\mathrm{R}$ et al, 1994]. In this context, the differential expression of PKC $\varepsilon$ as a function of development [Sen A et al, 2004] and the possibility that $\mathrm{PKC} \varepsilon$ has an important regulatory role in the $\mathrm{PGF}_{2 \alpha}$ induced $\mathrm{Ca}^{2+}$ signal can be interpreted as being of great physiological significance. The expression of PKC $\varepsilon$ and its activation by $\mathrm{PGF}_{2 \alpha}$ may shift the $\left[\mathrm{Ca}^{2+}\right]_{i}$ signal from a luteotropic threshold to a luteolytic one in Day 10, thereby playing a role in the differential sensitivity of the CL to $\mathrm{PGF}_{2 \alpha}$.

Blocking the action of all conventional PKC isozymes ( $\alpha, \beta I$, and $\beta I I)$ expressed in the bovine CL [Sen A et al, 2004] at both development stages had no effect on the $\mathrm{PGF}_{2 \alpha}$-induced $\mathrm{Ca}^{2+}$ signal. This supports the interpretation that these actions were specific for PKC $\varepsilon$. As mentioned earlier, conventional PKC isozymes also appear to be involved in mediating the inhibitory actions of $\mathrm{PGF}_{2 \alpha}$ on LH-stimulated P4 accumulation. However, the exact roles of these PKC isozymes are still unknown.

In summary, $\mathrm{PKC} \varepsilon$ appears to have a key regulatory role in the calcium signaling initiated by $\mathrm{PGF}_{2 \alpha}$, and this, at least in part, appeared to antagonize the inhibitory effect of $\mathrm{PGF}_{2 \alpha}$ on LH-stimulated P4 accumulation in cultures of Day 10 luteal steroidogenic cells. Therefore, we propose that the differential ability of both LLCs and SLCs to exhibit a $\mathrm{PGF}_{2 \alpha}$-induced rise in $\left[\mathrm{Ca}^{2+}\right]_{\mathrm{i}}$ as a function of development is due to the differential expression and activation of this isozyme in Day 10 corpora lutea. The inability of $\mathrm{PGF}_{2 \alpha}$ to decrease P4 secretion in Day 4 corpora lutea may be related to the absence of this PKC $\varepsilon$ at this developmental stage of the CL. Thus, based on the above observations, we propose that expression and activation of PKC $\varepsilon$ in the midphase bovine CL, shifts the $\mathrm{PGF}_{2 \alpha}$-induced $\left[\mathrm{Ca}^{2+}\right]_{\mathrm{i}}$ response to a threshold that allows activation of conventional PKC isozymes, and this in turn, decreases P4 accumulation characteristic of luteal regression. However, other mechanisms such as the tonic inhibition of P4 accumulation by ET-1 [Choudhary E et al, 2005], and nitric oxide [Friden BE et al, 2000; Tognetti T et al, 2003] may act in an additive fashion with $\mathrm{PGF}_{2 \alpha}$ to cause luteal regression during the mid- to late-luteal phase of the bovine CL. 

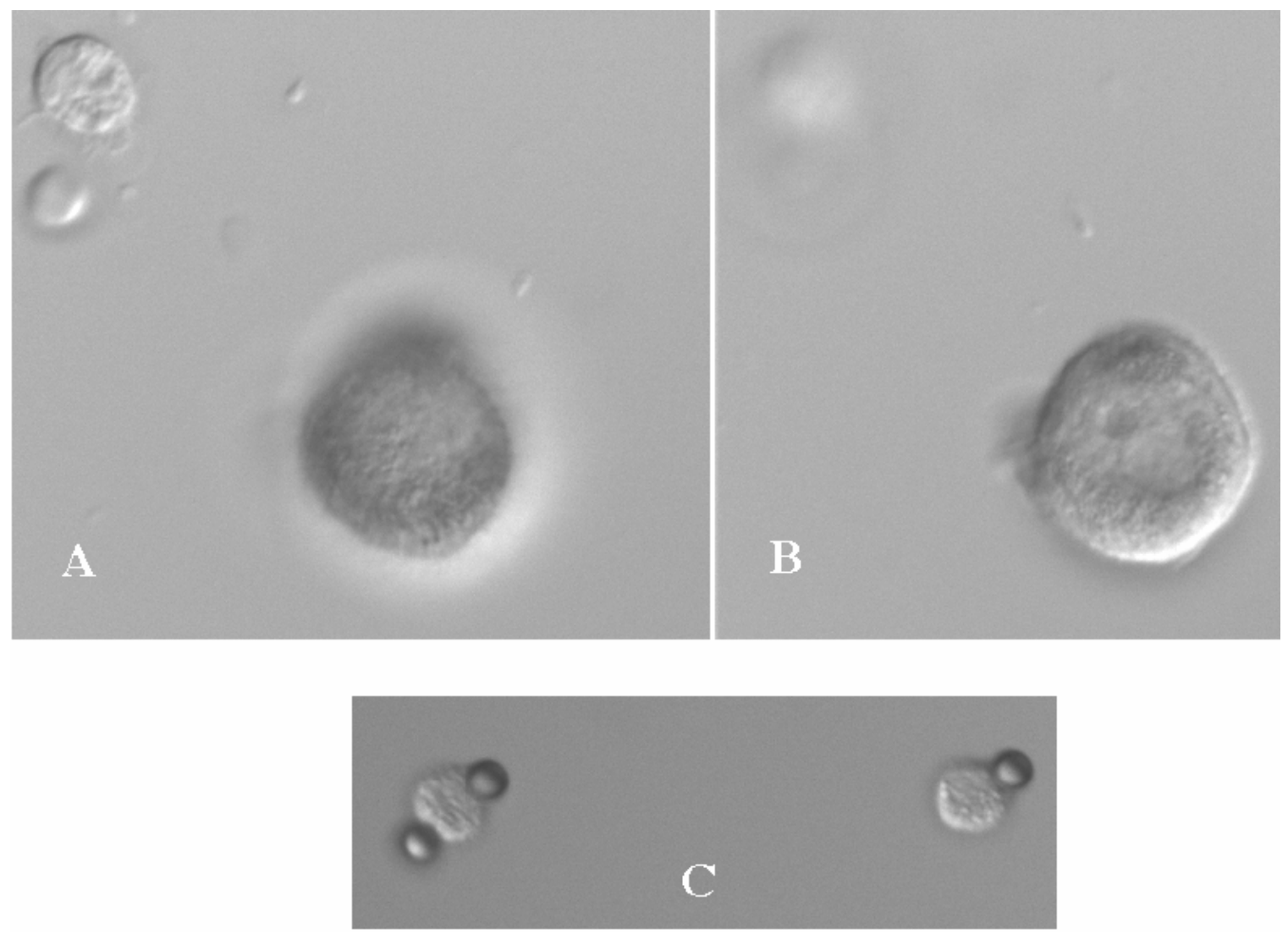

FIG. 1. Representative morphological characteristics of the three cell populations obtained from the dissociated bovine CL. Luteal steroidogenic (a and b) and endothelial cells were separated using magnetic Tosylactivated beads coated with BS-1 lectin as described in Materials and Methods. a) A small luteal steroidogenic cell (SLC), which typically had a diameter $<20 \mu \mathrm{m}$. b) A large steroidogenic cell (LLC); these cells typically had a diameter $>20 \mu \mathrm{m}$. c) Two luteal endothelial cells; these cells had one or two magnetic beads attached to their surface. All images were obtained using a x20 objective lens of an Olympus microscope equipped for Nomarsky microscopy. Bar in (a) $=20 \mu \mathrm{m}$ 


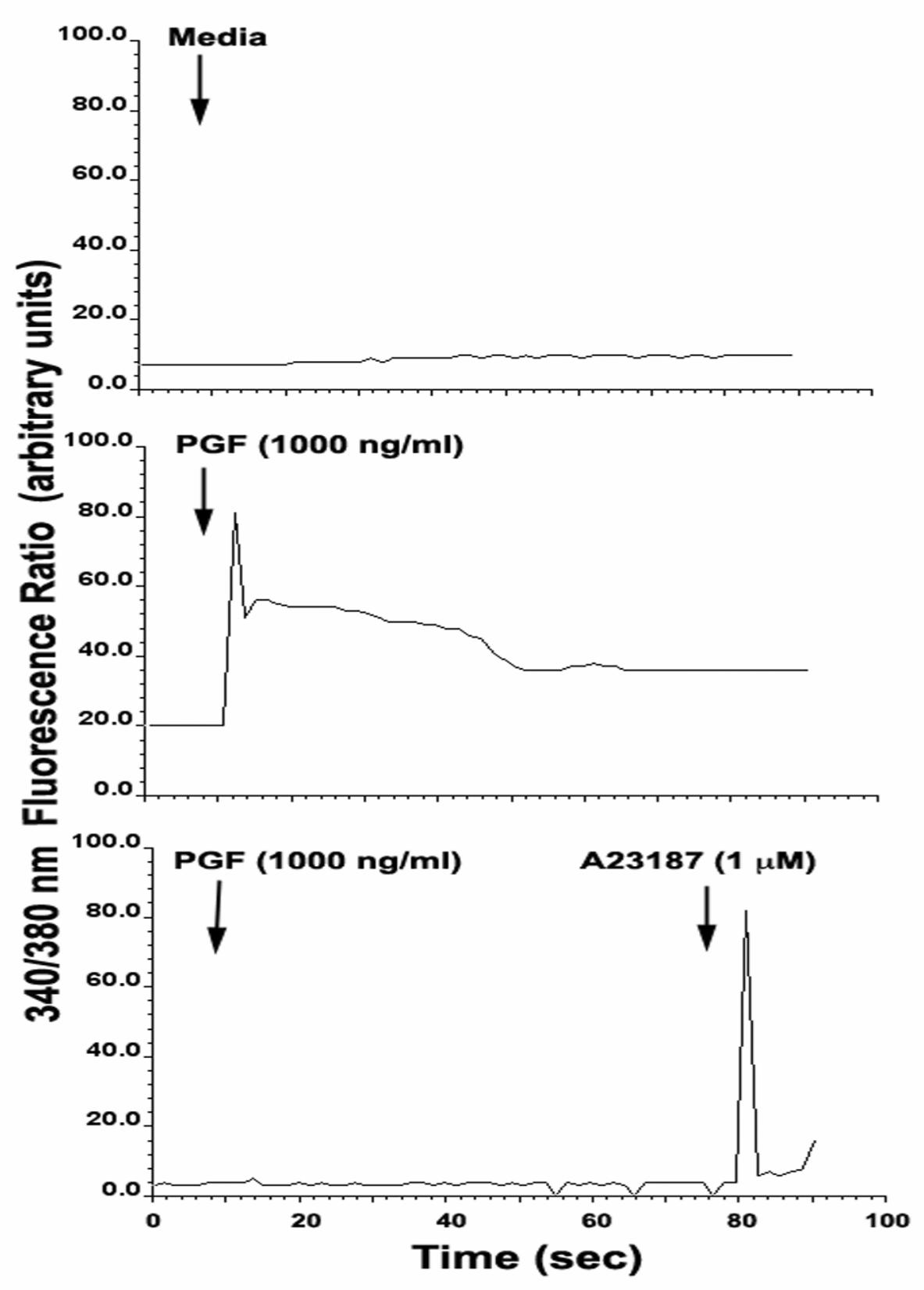

FIG.

2.

Specificity of

the $\mathrm{PGF}_{2 \alpha^{-}}$

induced $\mathrm{Ca}^{2+}$

response and

the $\mathrm{PKC}_{\mathrm{e}}$

inhibitor. The

cells were

isolated from

Day 10 bovine

corpora lutea

and prepared

for fura-2 AM

imaging of

$\left[\mathrm{Ca}^{2+}\right]_{\mathrm{i}}$ as

described in

Materials and

Methods. Data

are the relative

fluorescence

ratio $(340: 380$

nm) over time

(in seconds).

LLCs were

exposed at the indicated time (arrows) to vehicle media (top), to $\mathrm{PGF}_{2 \alpha}$ alone (1000 $\mathrm{ng} / \mathrm{ml}$; middle), and to $\mathrm{PGF}_{2 \alpha}(1000 \mathrm{ng} / \mathrm{ml})$ in the continuous presence of a $\mathrm{PKC}_{\varepsilon}$ specific inhibitor (bottom). At the end of this trace, the cell was exposed to the calcium ionophore, A23187 $(1 \mu \mathrm{M})$ to demonstrate that even though the $\mathrm{PKC}_{\varepsilon}$ inhibitor prevented $\mathrm{PGF}_{2 \mathrm{a}}$ from eliciting its typical calcium signal, the ionophore A23178 was able to elicit a calcium response in the same cell. 


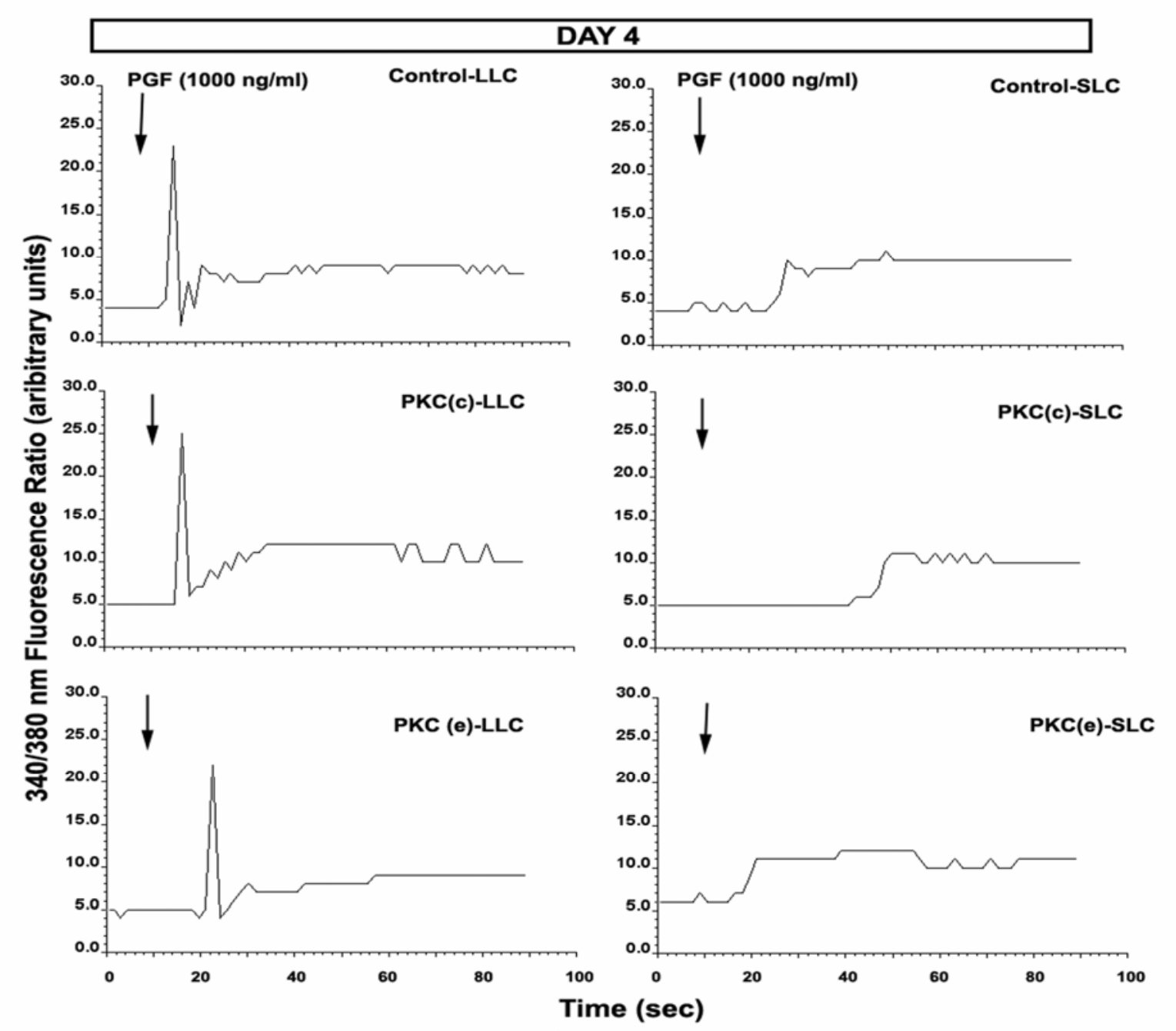

FIG. 3. Representative profiles of the $\mathrm{Ca}^{2+}$ responses induced by $1000 \mathrm{ng} / \mathrm{ml} \mathrm{PGF}_{2 \alpha}$ in single, large luteal cells (LLC; left) and small luteal cells (SLC) isolated from Day 4 bovine $\mathrm{CL}$ and the effects of PKC isozyme-specific inhibitors on this $\mathrm{PGF}_{2 \propto}$-stimulated $\mathrm{Ca}^{2+}$ response. The cells were isolated and prepared for fura-2 AM imaging of $\left[\mathrm{Ca}^{2+}\right]_{i}$ as described in Materials and Methods. Data are the relative fluorescence ratio (340:380 nm) over time (in seconds). LLCs (left) and SLCs (right) were exposed at the indicated time (arrows) to $\mathrm{PGF}_{2 a}$ alone (top; Control-LLC and Control SLC), to $\mathrm{PGF}_{2 a}$ in the continuous presence of a conventional PKC inhibitor (middle; PKC (c)-LLC and PKC (c)-SLC) and $\mathrm{PGF}_{2 \alpha x}$ in the continuous presence of a $\mathrm{PKC}_{E}$-specific inhibitor (bottom; PKC (e)-LLC and PKC (e)-SLC). In each panel, a line in the graph represents the trace of a single cell. The units used for the y-axis in the top left panel are different from all other panels in the figure. 


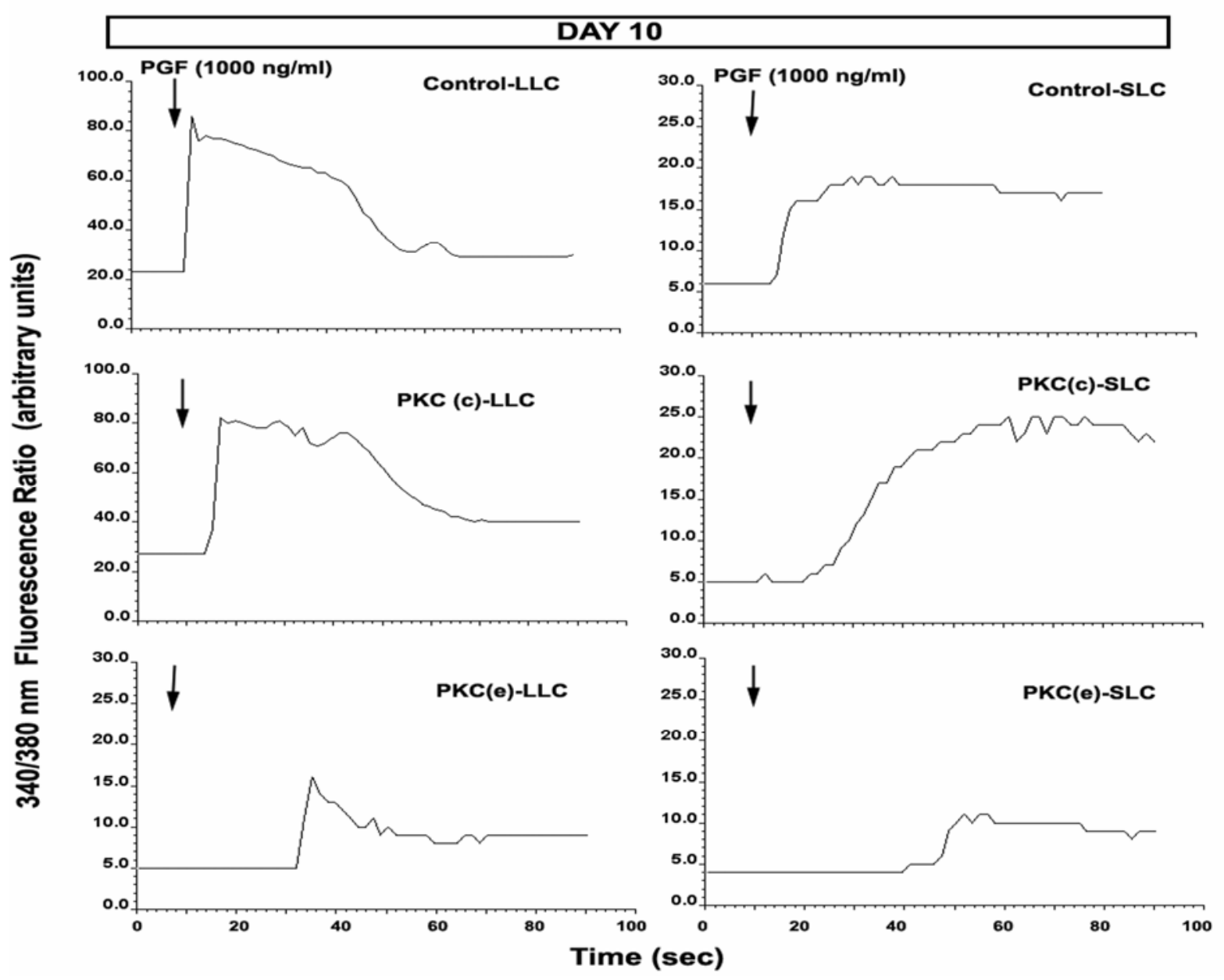

FIG. 4. Representative profiles of the $\mathrm{Ca}^{2+}$ response induced by $1000 \mathrm{ng} / \mathrm{ml} \mathrm{PGF}_{2 \alpha}$ in single, large luteal cells (LLC; left) and small luteal cells (SLC; all others panels) cells isolated from Day 10 bovine CL and the effects of PKC isozyme-specific inhibitors on this $\mathrm{PGF}_{2 \alpha}$-stimulated $\mathrm{Ca}^{2+}$ responses. The cells were isolated and prepared for fura-2 AM imaging of $\left[\mathrm{Ca}^{2+}\right]_{\mathrm{i}}$ as described in Materials and Methods. Data are the relative fluorescence ratio (340:380 nm) over time (in seconds). LLCs (left) and SLCs (right) were exposed at the indicated time (arrows) to $\mathrm{PGF}_{2 \alpha}$ alone (top; Control-LLC and Control SLC), to $\mathrm{PGF}_{2 \alpha}$ in the continuous presence of a conventional PKC inhibitor (middle; PKC (c)-LLC and PKC (c)-SLC) and $\mathrm{PGF}_{2 \alpha}$ in the continuous presence of a PKCe-specific inhibitor (bottom; PKC (e)-LLC and PKC (e)-SLC. In each panel, a line in the graphs represents the trace of a single cell. The scale units used for the y-axis in the top and middle left panels are different from all other panels in the figure. 


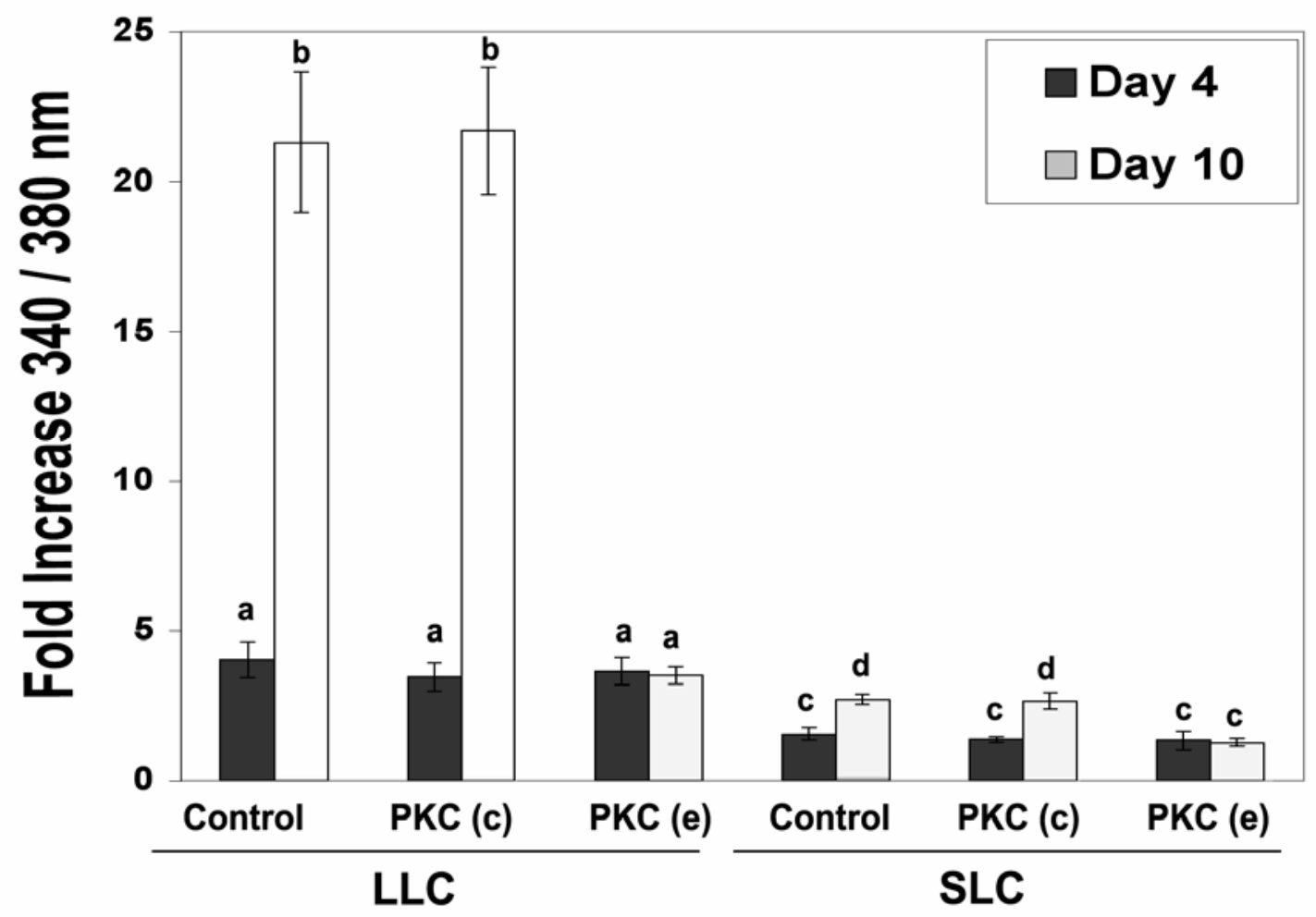

FIG. 5. Summary of the effects of conventional PKC [PKC (c)] and $\mathrm{PKC}_{\varepsilon}$ inhibitors [PKC ( $(\varepsilon)]$ on the $\mathrm{PGF}_{2 \alpha}$-stimulated rise in $\left[\mathrm{Ca}^{2+}\right]_{\mathrm{i}}$ in Day 4 and Day 10 LLCs and SLCs. The cells were isolated and prepared for fura-2 AM imaging of $\left[\mathrm{Ca}^{2+}\right]_{\mathrm{i}}$ as described in Materials and Methods. Cells were pretreated with either no inhibitors (control cells) or with $\mathrm{PKC}(\mathrm{c})$ - or $\mathrm{PKC}_{\epsilon}$-Specific inhibitor. Values are presented as the mean $\pm \mathrm{SEM}$ of the fold increase in $\left[\mathrm{Ca}^{2+}\right]_{i}$ induced by $\mathrm{PGF}_{2 \alpha}(1000 \mathrm{ng} / \mathrm{ml})$ from basal values observed before the stimulation with $\mathrm{PGF}_{2 \alpha}$. Statistical comparisons were made within cell type, developmental stage, and treatment; different letters on top of bars denote significantly different values $(P<0.05$ across treatments depicted by the bars; for Day $4, \mathrm{n}=116,224$, 225, 198, 189, and 208; and for Day 10, $\mathrm{n}=110,202,217,95,182$, and 205). 


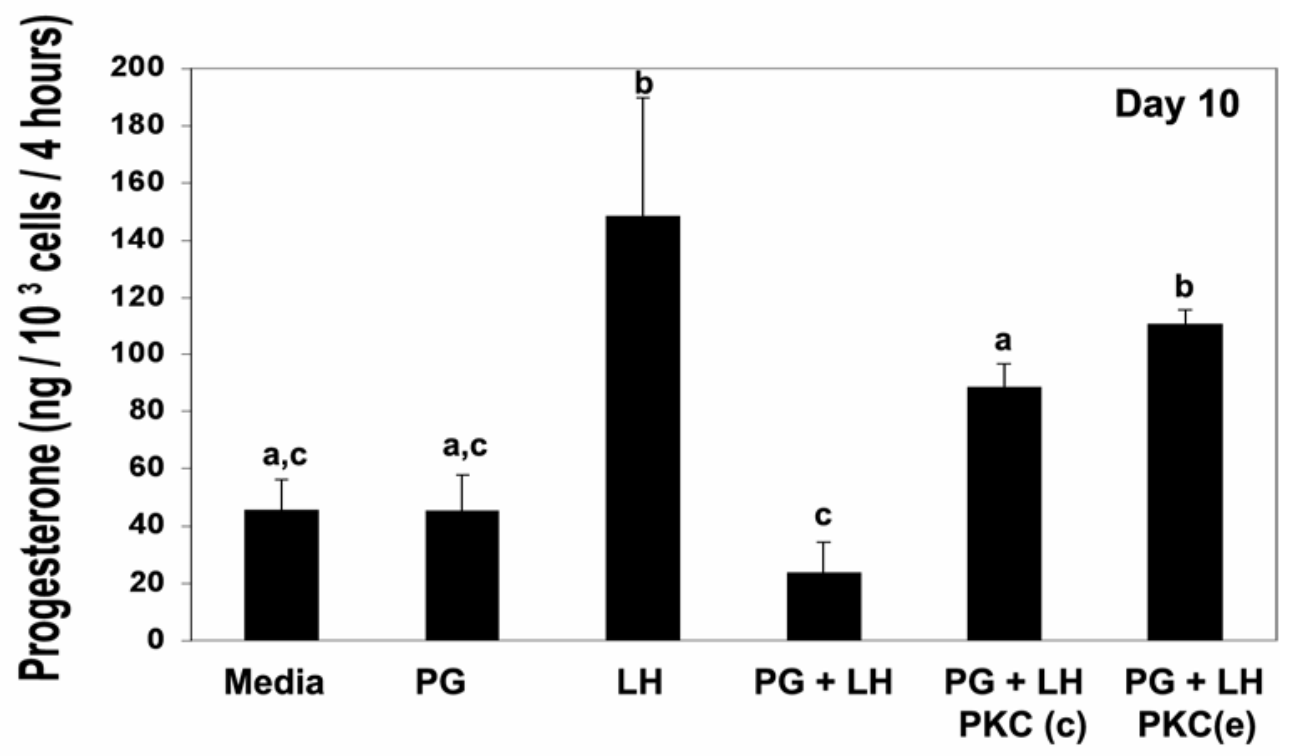

FIG. 6. Effects of conventional PKC [PKC (c)] and PKCe inhibitors [PKC (e)] on PGF $2 a^{-}$ actions on the basal and LH-stimulated progesterone accumulation in cultures of steroidogenic cells collected from Day 10 bovine CL. Progesterone accumulation was determined in culture media after $4 \mathrm{~h}$ of incubation in the following treatments: media alone (Media); $\mathrm{PGF}_{2 \alpha}(\mathrm{PG} ; 1000 \mathrm{ng} / \mathrm{ml}) ; \mathrm{PGF}_{2 \alpha}$ and LH (PG + LH; $1000 \mathrm{ng} / \mathrm{ml}$ and 100 ng/ml, respectively), $\mathrm{PGF}_{2 \alpha}, \mathrm{LH}$, and inhibitor conventional PKC [PKC (c) PG + LH; $1000 \mathrm{ng} / \mathrm{ml}, 100 \mathrm{ng} / \mathrm{ml}$, and $1 \mu \mathrm{M}$, respectively]; and $\mathrm{PGF}_{2 \alpha}, \mathrm{LH}$, and $\mathrm{PKC}_{\varepsilon}$ inhibitor [PKC ( $\varepsilon) \mathrm{PG}+\mathrm{LH} ; 1000 \mathrm{ng} / \mathrm{ml}, 100 \mathrm{ng} / \mathrm{ml}$, and $1 \mu \mathrm{M}$, respectively]. As explained for experiment 2 in Materials and Methods, all these treatments also contained saponin (50 $\mu \mathrm{g} / \mathrm{ml}$ ). Data are presented as the mean \pm SEM of four (Day 10) individual replicates (cows). Statistical comparisons were made across cell type, developmental stage, and treatment; different letters on top of bars denote significantly different values, $P<0.05$. 


\section{Chapter V: Cellular Source of Luteal PKC Isozymes and their Activation by Endothelin-1 (ET-1) in the Mid-phase Bovine Corpus Luteum (CL)}

\section{Introduction}

Progesterone $\left(\mathrm{P}_{4}\right)$ produced by the corpus luteum (CL) is necessary for establishing and maintaining pregnancy [McCrracken JA et al, 1999]. If pregnancy does not ensue, the $C L$ enters a regression or luteolytic process during which it loses the capacity to produce $\mathrm{P}_{4}$ and undergoes structural involution [Niswender GD et al, 2000]. Regulation of $\mathrm{P}_{4}$ production as well as luteal regression involves interactions between luteal endothelial and steroidogenic cells [Meidan R et al, 1999; O'Shea JD et al, 1989].

In mammals, prostaglandin $\mathrm{F}_{2 \alpha}\left(\mathrm{PGF}_{2 \alpha}\right)$ is the most important hormone associated with luteal regression [McCrracken JA et al, 1999; Niswender GD et al, 2000] and based on this knowledge, it has been widely used for the purpose of estrous synchronization in farm animals. However, despite its widespread application, the mechanisms by which $\mathrm{PGF}_{2 \alpha}$ induces luteal regression are not completely understood. For instance, the $\mathrm{CL}$ is resistant to the luteolytic actions of $\mathrm{PGF}_{2 \alpha}$ prior to day 6 of the estrous cycle, rendering prostaglandin treatment drastically less effective before that time [Inskeep EK, 1973].

Two important intracellular mediators of the luteolytic actions of $\mathrm{PGF}_{2 \alpha}$ in luteal steroidogenic cells [Niswender GD et al, 2000] are protein kinase C (PKC) and calcium ions $\left(\left[\mathrm{Ca}^{2+}\right]_{i}\right) . \mathrm{PKC}$ is a family of serine-threonine kinases that exist in at least 11 closely related isozymes [Newton AC, 1995]. We demonstrated by Western blot analysis that the array of PKC isozymes expressed in whole bovine CL includes $\alpha, \beta I, \beta I I, \varepsilon$ and $\mu$ [Sen A et al, 2004]; and that the amount of PKC $\varepsilon$ expressed in the day-10 CL was greater than in the day-4 CL. The latter observation lead us to propose that differential expression of $\mathrm{PKC} \varepsilon$ as a function of development could play a role in the $\mathrm{PGF}_{2 \alpha}$-induced luteal regression [Sen A et al, 2004; Sen A et al, 2005].

Studies in different species and cell types indicate that differences in co-activator requirements for each PKC isozymes as well as distinct cellular localization contribute to isozyme functional specificity [Lehel C et al, 1994; Borner C et al, 1995; Pauken CM et al, 2000]. The cellular source(s) for each PKC isozyme expressed in the CL has not been examined and consequently, our ability to approach several strategies to determine a 
specific role for each PKC isozyme in luteal physiology is limited. For instance, available strategies to down- or up-regulate expression of a given PKC isozyme for assessing its function require knowledge of the normal temporal and spatial (cellular source) expression of that isozyme.

Several authors collectively have indicated that endothelin-1 (ET-1), secreted by luteal endothelial cells, plays a role in luteal regression [Meidan R et al, 1999; O'Shea JD et al, 1989; Girsh E et al, 1996a; Levy N et al, 2000; Girsh E et al, 1996b; Ohtani M et al, 1998; Milvae RA, 2000; Wright MF et al, 2001; Levy N et al, 2001; Hinckley ST et al, 2001]. While some investigators have suggested that ET-1 is a mediator of the luteolytic actions of $\mathrm{PGF}_{2 \alpha}$, [Meidan R et al, 1999; Girsh E et al, 1996a; Girsh E et al, 1996b; Milvae RA, 2000] our own data have indicated that ET-1 although a tonic inhibitor of $\mathrm{P}_{4}$ synthesis, is not necessarily a mediator of $\mathrm{PGF}_{2 \alpha}$ actions [Choudhary $\mathrm{E}$ et al, 2005]. The intracellular mediator(s) of ET-1 actions in luteal regression is not yet known, however, actions of ET-1 in luteal cells [Choudhary E et al, 2005] as well as in granulosal cells [Flores JA et al, 1992] are known to involve, at least in part, the participation of phospholipase C (PLC), inositol phosphates and intracellular calcium. Moreover, little is known about the intracellular mediators or mechanism(s) involved in the inhibition of $\mathrm{P}_{4}$ synthesis by ET-1 in the CL.

Thus, the aims of these studies were: (1) To determine the temporal expression of mRNA encoding PKC $\varepsilon$ gene as a function of luteal development, (2) to identify the cellular source for each luteal PKC isozyme, (3) to investigate the ability of ET-1 to activate in vitro, the different luteal PKC isozymes in the day-10 CL and (4) to determine the role of luteal PKC isozymes in the ET-1 mediated inhibition of $\mathrm{P}_{4}$ accumulation in steroidogenic cell cultures from day-4 and day-10 CL.

\section{Materials and Methoda}

\section{Luteal Tissue Collection}

Bovine CL were collected as previously described [Sen A et al, 2004; Choudhary E et al, 2005; Sen A et al, 2005]. Briefly, behavioral estrus was determined in nonlactating beef cows. The day of standing estrus was designated as Day-0 [Casida LE, 1959] and after two cycles, day-1, day-4, day-10 and day-17 CL were collected by 
ovariectomy (day-1 and -4) or blunt dissection (day-10 and -17) via supravaginal incision under epidural anesthesia [Sen A et al, 2004; Sen A et al, 2005; Choudhary E et al, 2005]. For the epidural anesthesia, 6 to $9 \mathrm{ml} \%$ lidocaine were administered for cows weighing $450-700 \mathrm{~kg}$ (Butler Company, Columbus, OH). The CL or ovary was collected into icecold phosphate- buffered saline (PBS) $\mathrm{pH} 7.4$ and transported to the laboratory within 15 to $30 \mathrm{~min}$ after collection. The West Virginia University Animal Care and Use Committee reviewed and approved the protocol for the tissue collection (ACUC \# 010809).

\section{Luteal Cell Dispersion and Purification}

Luteal cell dispersion was performed as previously described [Sen A et al, 2005; Choudhary E et al, 2005]. Briefly, the luteal tissue was dissociated in cell dispersion medium (CDM, M-199 containing 0.1\% BSA, $25 \mathrm{mM}$ Hepes, $100 \mathrm{U} / \mathrm{ml}$ fungicide) containing collagenase type IV (GIBCO, Invitrogen Life Technologies, Carlsbad, CA, $420 \mathrm{U} / \mathrm{ml} / \mathrm{g}$ of tissue). The dispersed luteal cells were then suspended in 1\% PBS, mixed with magnetic tosylactivated beads (Dynal Biotech, Lake Success, NY) coated with BSlectin and placed for $25 \mathrm{~min}$ at $4^{\circ} \mathrm{C}$ on a rocking platform. The bead-adherent cells were washed with 1\% PBS and concentrated using a magnetic particle concentrator (Dynal Biotech, Lake Success, NY). Both BS-1-adhering (endothelial cells) and non-adherent cells (steroidogenic luteal cells) were then collected by this procedure. Cell viability and density were determined using tryptan blue exclusion and a hemacytometer.

\section{Semi-quantitative reverse transcriptase- PCR}

Total RNA was isolated with Trizol reagent according to the manufacturer's instructions (GIBCO BRL, Gaithersburg, MD). The isolated RNA was quantified spectroscopically at $260 \mathrm{~nm}$ and used in a one-step semi-quantitative reverse transcriptase-PCR (RT-PCR, Qiagen, Valencia, CA) for PKC $\varepsilon$ and GAPDH (reference gene). The identity of the primers for PKC $\varepsilon$ were those published elsewhere [Webb BL

et al, 1997]; sense 5'-AGCTTGAAGCCCACAGCCTG-3'; antisense 5'CTTGTGGCCGTtGaCCTGATG -3'. Primers for GAPDH amplification have been published [Wright MF et al, 2001; Choudhary E et al, 2004], sense 5'- 
TGTTCCAGTATGATTCCACCC-3'; antisense 5'-TGTTCCAGTATGATTCCACCC3'. The specificity for this primer set has been documented [Wright MF et al, 2001; Choudhary E et al, 2004], while the primer specificity for amplification of PKC $\varepsilon$ mRNA was confirmed here by using the nucleotide database of National Center for Biotechnology Information

(NCBI, http://www.ncbi.nlm.nih.gov/entrez/query.fcgi?DB=pubmed) with the BLAST software. The RT-PCR assay conditions were as follows: $50{ }^{\circ} \mathrm{C}$ for 30 mins for reverse transcription reaction, $95^{\circ} \mathrm{C}$ for $15 \mathrm{~min}$ for activation of reverse transcriptase enzyme, $95^{\circ} \mathrm{C}$ for $50 \mathrm{sec}$ for PCR cycles, $58^{\circ} \mathrm{C}$ for $30 \mathrm{sec}$ for denaturing, $72^{\circ} \mathrm{C}$ for $1 \mathrm{~min}$ for annealing, extension, followed by $5 \mathrm{~min}$ final extension at $72^{\circ} \mathrm{C}$. The RT-PCR products were electrophoresed on 2\% agarose gel stained with ethidium bromide and viewed using the Fluro-S MultiImager (BioRad Laboratories, Hercules, CA). Data were collected using densitometric analysis of Quantity One quantification software package (Version 4, BioRad Laboratories, Hercules, CA). The intensity of the signal corresponding to PKC $\varepsilon$ was standardized by the corresponding intensity of GAPDH control in that sample.

\section{Semi-quantitative Western Blotting}

Proteins from separated luteal cell populations were isolated by sonication followed by centifugation at $100 \mathrm{X} \mathrm{g}$ for $10 \mathrm{~min}$ to separate cellular debris. Protein concentration in the samples was determined by BioRad assay (Hercules, CA) with BSA (Gibco BRL, Life Technologies, Grand Island, N.Y.) as standard. Ten $\mu g$ / lane of sample protein was used for semi-quantitative western blot analysis as previously described [Sen A et al, 2004]. The following primary antibodies were used in this experiment: mouse anti-actin monoclonal antibody (used at a dilution of 1:3000 [v / v]; Chemicon International, Inc., Temecula, CA); four PKC isozyme specific $(\alpha, \beta I, \beta I I$ and $\varepsilon)$ polyclonal antibodies (used at a dilution 1:1000 [v/v]; Gibco). The following secondary antibodies were used in this experiment. Anti-rabbit (1:5000 [v / v]; Amersham Pharmacia Biotech, Piscataway, NJ) and anti-mouse (1:30,000 [v/v]; Gibco) horseradish peroxide-conjugated antibodies. Validation of the semi-quantitative western blot analysis and stripping conditions have been determined previously [Sen A et al, 2004]. The intensity of the signal corresponding to the protein of interest was standardized by the 
corresponding intensity of the actin control in that sample. Normalization of data allowed us to estimate, in a semi-quantitative manner, the amounts of protein in the samples of interest.

\section{Immunohistological assay}

Frozen CL were sectioned at $10 \mu \mathrm{M}$ thickness using a cryostat HM505 E (Microm Laborgerate $\mathrm{GmbH}$ ) and towed-mounted on microscope slides. These sections were used for immunohistochemistry. The tissue sections were fixed with ice cold acetone for 15 min, followed by $3 \mathrm{X}$ wash in TBS for $10 \mathrm{~min}$ each. Blocking of non-specific binding sites was accomplished with 5\% normal goat serum (NGS, Sternberger Monoclonals, Inc, Baltimore, MD) in TBS for $30 \mathrm{~min}$ in a humid chamber at room temperature. Sections were then incubated with $\mathrm{PKC} \varepsilon$ specific primary $\left(1^{\circ}, \mathrm{Gibco}\right)$ antibody at a dilution of 1:500 [v / v] in $1 \%$ NGS-TBS at $4^{\circ} \mathrm{C}$ overnight in humid chambers. The next day the slides were washed $3 \mathrm{X}$ in TBS for 10 min each followed by incubation with secondary $\left(2^{\circ}\right)$ antibody, anti rabbit IgG (Amersham Pharmacia Biotech, Piscataway, NJ) at a dilution of 1:200 [v/v] in 1\%NGS-TBS at room temperature for $30 \mathrm{~min}$ in humid chambers. Endogenous peroxidase activity was reduced by incubating the sections in a solution of 3\% hydrogen peroxide in methanol at room temperature for 30-45 min. Tissue sections were then washed $2 \mathrm{X}$ in TBS for $10 \mathrm{~min}$ each and incubated with rabbit PAP (Sternberger Monoclonals Incorporated, Baltimore, MD) complex at a dilution of 1:200 $[\mathrm{v} / \mathrm{v}]$ in $1 \% \mathrm{NGS}-\mathrm{TBS}$ at room temperature for $30 \mathrm{~min}$. The PAP solution was removed and slides were washed $3 \mathrm{X}$ in TBS for $10 \mathrm{~min}$ each. The CL sections were incubated with the substrate, 3,3'-Diaminobenzidine chromogen solution (DAB, prepared according to the manufacturers instructions; Biogenex, San Ramon, CA) at room temperature for 3 $\min , 5 \mathrm{~min}$ and $10 \mathrm{~min}$. Slides incubated for $5 \mathrm{~min}$ showed the best signal to noise ratio and that was selected as the incubation time to be used in all sections of the four CL used for analysis. Slides were allowed to dry at room temperature and an aqueous mounting medium with anti-fading agents (Gel/Mount Biomedia Corp. Foster City, CA) was added to completely cover the tissue and cover slips were placed on the slides. These slides were later observed under an Olympus PROVIS AX70 microscope (Olympus America Inc., Melville, NY). Each treatment was performed in three consecutive sections on 
different slides. Pre-incubation of the primary antibody with excess antigenic peptide has previously [Sen A et al, 2004; Graness A et al, 1997] validated the specificity of the primary antibody. In this study specificity of the immunohistological detection was further determined by: (1) omission of primary antibody, (2) omission of secondary antibody, and (3) omission of PAP antibody. The slides were examined using the Olympus PROVIS AX70 microscope for the presence / absence of specific brown color accumulation indicating immunoreactivity.

Experiment 1: Temporal expression of mRNA encoding PKC $\varepsilon$ during luteal development

The temporal expression of mRNA encoding PKC $\varepsilon$ was examined using a onestep semi-quantitative reverse transcriptase-PCR assay with RNA samples isolated from day-1 $(n=3)$, day-4 $(n=3)$, day-10 $(n=4)$ and day-17 $(n=3)$ CL samples. The amount of total RNA in the assay for each developmental day was adjusted to $200 \mathrm{ng}$ per reaction and the number of cycles was optimized to 26 and 40 for amplification of GAPDH and PKC $\varepsilon$ respectively. Subsequently, as under these conditions, the amount of mRNA encoding PKC $\varepsilon$ was lowest in the day-1 samples, the RT-PCR assay also was performed with different amounts of total RNA (100 ng, $300 \mathrm{ng}$ and $500 \mathrm{ng}$ ) for samples with lowest day-1, and highest day-10 amounts of PKC $\varepsilon$ mRNA. The validity of the temporal expression of mRNA encoding PKC $\varepsilon$ gene found by using the semi-quantitative RTPCR was further corroborated by one real-time PCR.

\section{Experiment 2: Cellular source of luteal PKC isozymes}

The cellular source for each luteal PKC isozyme was examined using a semiquantitative Western blot analysis of proteins isolated from enriched steroidogenic and endothelial cell populations collected from day-10 CL $(n=3)$ and by an immunohistological detection of PKC $\varepsilon$ on luteal sections prepared from frozen tissue collected on day-10 of the ovarian cycle $(n=4)$. 


\section{Experiment 3: Ability of ET-1 to activate luteal PKC isozymes}

Day-10 CL were dissected free of any connective tissue and then cut into small 1 $\mathrm{mm}^{3}$ fragments just before the experiment was initiated. The CL fragments were added to disposable culture tubes (Fisher Scientific, Pittsburgh, PA) containing MEM-HEPES (GIBCO BRL, Life Technologies) alone or MEM-HEPES containing 100 nmol ET-1. The tissue and media were separated by centrifugation after $10 \mathrm{~min}$, snap frozen in liquid nitrogen and stored at $-80^{\circ} \mathrm{C}$. The tissue was later pulverized and homogenized in buffer containing $20 \mathrm{mmol}$ Tris- $\mathrm{HCl}$, 0.25-mol sucrose, $1.2 \mathrm{mmol}$ EGTA, 0.1 PMSF, $20 \mu \mathrm{g} / \mathrm{ml}$ leupeptin, and $20 \mathrm{mmol} 2$-mercaptoethanol. The homogenized tissue was centrifuged at $1,000 \mathrm{X} g$ for $2 \mathrm{~min}$ at $4^{0} \mathrm{C}$ to remove floating tissue particles. This supernatant was used for subcellular fractionation by differential and discontinuous sucrose gradient centrifugation. The cytosolic fraction was obtained by centrifugation at 100,000-x g for $60 \mathrm{~min}$. The pellet of the first $100,000 \mathrm{X} \mathrm{g}$ centrifugation was homogenized in homogenization buffer containing $1 \%$ triton-X 100. The homogenized pellet was centrifuged at $100,000 \mathrm{X} \mathrm{g}$ for $60 \mathrm{~min}$. This supernatant constituted the membrane fraction. Protein concentrations in the cytosolic and membrane fractions were determined using a BioRad assay with BSA as standards. $10 \mu \mathrm{g} /$ lane of sample proteins were analyzed by a semi quantitative Western blotting as previously described [Sen A et al, 2004]. Data are presented as the ratios of actin-corrected optical density (OD) detected for the $\mathrm{PKC}$ isozyme in the membrane fraction to the corrected OD for the same isozyme in the cytosolic fraction $(\mathrm{M} / \mathrm{C})$.

Experiment 4: Role of luteal PKC isozymes in the ET-1 mediated inhibition of $\mathrm{P}_{4}$ synthesis in day-4 and day-10 luteal steroidogenic cells

The aim of this experiment was to test the involvement of conventional PKC ( $\alpha$, $\beta \mathrm{I}, \beta \mathrm{II})$ and novel PKC isozymes $(\varepsilon)$ in ET-1 induced inhibition of $\mathrm{P}_{4}$ synthesis [Choudhary E et al, 2005] by day-4 $(n=4)$ and day-10 $(n=3)$ luteal steroidogenic cells. This experiment was performed as previously described [Sen A et al, 2005]. Briefly, enriched population of steroidogenic cells $\left(1 \times 10^{3}\right.$ cells $)$ were added in small aliquots $(100 \mu \mathrm{l})$ to wells (Corning 35-mm cell culture clusters; Fisher Scientific Company, Blawnox, PA), containing the following: 1) $1 \mathrm{ml} \mathrm{M} 199$ and saponin; 2) 1ml M199, 
saponin and LH (100ng/ml); 3) 1ml M199, saponin and ET-1 (100nM); 4) 1ml M199, saponin, LH and ET-1; 5) 1ml M199, saponin, LH, ET-1 and conventional PKC inhibitor $(1 \mu \mathrm{M})$ and 6) $1 \mathrm{ml} \mathrm{M199}$, saponin, LH, ET-1 and PKC $\varepsilon$ inhibitor $(1 \mu \mathrm{M})$. Each treatment was applied in duplicate to cells from each CL. The cells were incubated for $4 \mathrm{~h}$ at $37^{\circ} \mathrm{C}\left(95 \%\right.$ air, $\left.5 \% \mathrm{CO}_{2}\right)$. After incubation, medium free of cells was stored frozen until assayed for $\mathrm{P}_{4}$ measurement by radioimmunoassay (RIA) as previously described [Sen A et al, 2005; Choudhary E et al, 2005]. The standard curve for this RIA ranged from $10 \mathrm{pg} / \mathrm{ml}$ to $800 \mathrm{pg} / \mathrm{ml}$, and the intra-assay and inter-assay coefficients of variation were $9.2 \%$ and $12.8 \%$, respectively.

\section{Statistical Analysis}

Statistical analyses were performed using JMP, a statistical software program from Statistical Analysis Systems [Cary NC, 1994]. The results were expressed as the mean \pm SEM. Two-way ANOVA followed by Tukey-Kramer Honestly Significant Difference test was used to determine statistically significant differences between amounts of PKC $\varepsilon$ mRNA among different luteal developmental stages or PKC isozymes and cell types or PKC isozymes and ET-1 treatment. One-way ANOVA followed by a Tukey-Kramer honestly significant difference test was used to determine statistically significance differences in $\mathrm{P}_{4}$ accumulation. $\mathrm{A}$ value of $\mathrm{P}<0.05$ was considered significant.

\section{Results}

\section{Experiment 1}

Figure 1A shows the profiles for the amount of luteal mRNA encoding PKC $\varepsilon$ at the four luteal developmental stages examined. Abundance of PKC $\varepsilon$ mRNA gradually increased from day- 1 to day-10 CL. There were increases from day- 1 to day- 4 and from day-4 to day $10(\mathrm{P}<0.05)$. No further increase in the amount of mRNA encoding PKC $\varepsilon$ was observed in day-17 CL; the amount of PKC $\varepsilon$ mRNA in day-17 was similar to that of day-10. 
A representative picture of the RT-PCR products obtained using primers for PKC $\varepsilon$ and GAPDH from day-1 and day-10 samples is shown in Figure 1B. Typically, the sizes of the amplified PKC $\varepsilon$ and GAPDH fragments were 480 and $900 \mathrm{bp}$, respectively [Wright MF et al, 2001; Webb BL et al, 1997; Choudhary E et al, 2004].

When the RT-PCR assay was performed using increasing amounts of RNA / reaction (100, 300 and $500 \mathrm{ng} /$ reaction), in the day-1 samples, an amplified fragment corresponding to the PKC $\varepsilon$ mRNA was obtained only when 300 and $500 \mathrm{ng} /$ reaction were used. In contrast, when the RNA from day-10 samples was used, all three amounts of RNA were effective for amplifying the cDNA fragment corresponding to $\mathrm{PKC} \varepsilon$ (Figure 1B). This quantitative relationship is shown in Figure 1C. Furthermore, the abundance of the amplified fragment in the day-1 samples was always lower than that amplified in the day-10 samples (Figure 1C). This clearly indicates that amplified product was a function of the amount of mRNA template and that this in turn, was expressed at lower concentrations as a function of luteal development as depicted in the summarized data in Figure 1A. The real-time PCR experiment corroborated the observation that the abundance of the RNA encoding PKC $\varepsilon$ in day-1 samples was lower than in day-10 samples (data not shown).

\section{Experiment 2}

Figure $2 \mathrm{~A}$ shows a representative blot for $\mathrm{PKC} \alpha, \varepsilon$ and actin obtained from the enriched luteal cell populations tested. PKC $\varepsilon$ was detected exclusively in the steroidogenic cells (Figure 2A) in contrast to PKC $\alpha$ that was detected in both the cell populations. Figure 2B shows the summary of the amount of protein corresponding to PKC $\alpha, \beta \mathrm{I}, \beta \mathrm{II}$ and $\varepsilon$ in separated steroidogenic (LLC and SLC) and endothelial cells from day-10 CL. Although, both steroidogenic and endothelial cells expressed PKC $\alpha, \beta \mathrm{I}$ and $\beta I I$, their amounts were significantly lower in endothelial cells than in setroidogenic cells $(\mathrm{P}<0.05)$. Furthermore, in steroidogenic cells, all PKC isozymes were expressed in equal amounts; whereas in endothelial cells, $\alpha$ and $\beta$ II isozymes were expressed in higher amounts than $\beta I(P<0.05)$. 
The immunohistological assay of day-10 CL sections revealed that PKC $\varepsilon$ was detectable in what appeared to be LLC and SLC (Figure 3, Panel C). Immuno-reactivity in these was specific, because it was abolished in all the controls tested (Figure 3, Panel A and B). Immuno-reactivity was not observed in endothelial cells of any of the vascular components examined (Figure 3).

\section{Experiment 3}

Figure 4A shows a representative blot obtained with the protein samples isolated from tissue of experiment 3 to examine the cellular redistribution of PKC $\varepsilon$ as a function of stimulating the luteal tissue with ET-1 (100nM). In luteal tissue samples treated with MEM-HEPES (Media), PKC $\varepsilon$ was detected only in the cytoplasm (Figure 4A, right panel). In contrast, stimulating the luteal tissue with ET-1 resulted in the detection of PKC $\varepsilon$ in the cell membrane fraction (Figure 4A, left panel). Figure 4B summarizes the data for PKC redistribution for all the isozymes tested. In spite of the fact that in MEMHEPES-treated luteal samples (Figure 4B) PKC $\alpha, \beta$ I and $\beta$ II were detected in both the cytoplasmic and cell membrane fractions, ET-1 was able to increase the amount of PKC $\alpha$ and $\beta \mathrm{I}$ detected in the cell membrane fraction $(\mathrm{P}<0.05)$. In contrast, no cellular redistribution of PKC $\beta$ II was induced by similar ET-1 stimulation (Figure 4B). In our previous study [Sen A et al, 2004] PKC $\alpha$ was not detected in both the cytoplasmic and cell membrane fractions of media-treated samples. In this study, in only one out of five animals PKC $\alpha$ was detected in both membrane and cytosolic fraction in media-treated samples. This discrepancy may be due to variability among animals.

\section{Experiment 4}

To analyze the involvement of luteal PKC isozymes in the luteolytic actions of ET-1, we measured basal and LH-induced $\mathrm{P}_{4}$-induced accumulation in the presence and absence of conventional PKC and PKC $\varepsilon$ specific inhibitor [Sen A et al, 2005]. Moreover, based on Choudhary et al's work [Choudhary E et al, 2005], $100 \mathrm{nM}$ concentration of ET-1 was used in this study. 
In day-4 enriched steroidogenic cells ET-1 and LH had no effect on basal $\mathrm{P}_{4}$ accumulation (Fig 5A). In contrast when cells were incubated with ET-1 and LH the $\mathrm{P}_{4}$ accumulation values were reduced below basal condition. This inhibitory effect of ET-1 on $\mathrm{P}_{4}$ accumulation was significantly $(\mathrm{P}<0.05)$ antagonized in cells incubated with conventional PKC inhibitor, LH and ET-1. PKC $\varepsilon$ inhibitor did not have any affect on $\mathrm{P}_{4}$ accumulation when incubated with LH and ET-1.

$\mathrm{P}_{4}$ accumulation in day-10 enriched population of steroidogenic cells was three times higher than in day-4 cells for all the treatments tested (Fig 5B). ET-1 had no effect on basal $\mathrm{P}_{4}$ accumulation. However, $\mathrm{LH}$ induced a significant $(\mathrm{P}<0.05)$ increase in $\mathrm{P}_{4}$ accumulation over that observed under basal conditions, while ET-1 significantly $(\mathrm{P}<$ 0.05) decreased this effect of $\mathrm{LH} . \mathrm{P}_{4}$ accumulation in cells incubated with either conventional or $\varepsilon$ specific PKC inhibitor, LH and ET-1 were same as LH-induced values (Fig 5B).

\section{Discussion}

The present data demonstrate that the steroidogenic cells constitute the source of PKC $\varepsilon$ in the bovine CL. This important observation supports our previous suggestion that this isozyme may play an important role in regulation of $\mathrm{P}_{4}$ synthesis in the CL of the mid-late phase [Sen A et al, 2005]. Furthermore, our immunohistological data strongly indicate that PKC $\varepsilon$ is found in both large and small steroidogenic luteal cells. This observation supports the report that the $\mathrm{PGF}_{2 \alpha^{-}}$induced rise in $\left[\mathrm{Ca}{ }^{2+}\right]_{\mathrm{i}}$ was decreased in LLC and SLC when their PKC $\varepsilon$ was inhibited [Sen A et al, 2005].

It could be argued that the detected expression of $\mathrm{PKC} \alpha, \beta \mathrm{I}$ and $\beta \mathrm{II}$ in endothelial cells could be due to contamination of the enriched EC population with steroidogenic cells. However, we have reported that $\mathrm{PKC} \alpha, \beta \mathrm{II}$ and $\varepsilon$ are expressed in similar amounts in day-10 CL [Sen A et al, 2004]. Thus, it is unlikely that only PKC $\alpha$, and $\beta I I$ but not PKC $\varepsilon$ would be detected in the contaminated EC population. Based on this argument we interpret that the presence of these isoforms in EC is more likely due to their being expressed by these cells rather than by SC contamination. Although PKC $\alpha, \beta I$ and $\beta$ II 
were expressed in both steroidogenic and endothelial luteal cells, their amounts were significantly less in endothelial than in steroidogenic cells. Whether this difference in expression of $\mathrm{PKC} \alpha, \beta \mathrm{I}$ and $\beta \mathrm{II}$ between these two luteal cell types has any physiological significance is still unclear. Interestingly, Wu et al [Wu YL et al, 2001] reported that PKC $\alpha$ and $\beta$ acting on E-box DNA elements specifically increased Cox-2 transcription in LLC. As far as we know, the role for these PKC isozymes in luteal endothelial cells has not been examined previously.

The lower expression of mRNA encoding PKC $\varepsilon$ in the early luteal stage (day-1 and day-4) than in the mid-late luteal stage (day-10 and day-17) supports our previous observation of differential expression of PKC $\varepsilon$ protein as a function of development [Sen A et al, 2004]. We reported that the amount of protein corresponding to PKC $\varepsilon$ was barely detectable in day-4 CL, while it was significantly upregulated in the day-10 CL [Sen A et al, 2004]. These observations indicate that the lower amount of PKC $\varepsilon$ protein in the early CL, at least in part, is due to lesser availability of PKC $\varepsilon$ mRNA at this developmental stage. This interpretation is supported further by the observation that the amount of total mRNA necessary to amplify a cDNA product corresponding to $\mathrm{PKC} \varepsilon$ in the day-10 samples was greater than from day-1. However, the regulatory mechanism(s) of PKC $\varepsilon$ gene expression during CL development are currently not known.

The potential physiological significance of the differential expression of PKC $\varepsilon$ during the development of the CL is that it could participate in the cellular mechanisms rendering the early $\mathrm{CL}$ resistant to the antisteroidogenic actions of $\mathrm{PGF}_{2 \alpha}$. Importantly, the ability of ET-1, like $\mathrm{PGF}_{2 \alpha}$ [Sen A et al, 2004], to activate PKC $\alpha, \beta$ I and especially $\varepsilon$ in day-10 steroidogenic cells underlines the importance of PKC $\varepsilon$ in luteal regression. Choudhary et al [Choudhary E et al, 2005], demonstrated that ET-1 induced increases in $\left[\mathrm{Ca}^{2+}\right]_{\mathrm{i}}$ in steroidogenic and endothelial luteal cells. The ability of ET-1 to activate the metabolism of phosphoinositides, intracellular calcium and PKC also has been reported in swine granulosal cells [Flores JA et al, 1992], rat gonadotropes [Stojilkovic SS et al, 1992] and many other tissues [Badr KF et al, 1989; Simonson MS et al, 1989]. All these observations further support the fact that ET-1, like $\mathrm{PGF}_{2 \alpha}$ utilizes, at least in part, the PLC effector system with PKC and calcium as intracellular mediators. 
We have proposed that ET-1 appears to be a tonic inhibitor of luteal $\mathrm{P}_{4}$ production [Choudhary $\mathrm{E}$ et al, 2005] rather than a mediator of $\mathrm{PGF}_{2 \alpha}$ actions as suggested by other investigators [Girsh E et al, 1996a; Levy N et al, 2000; Girsh E et al, 1996b]. We demonstrated that the early $\mathrm{CL}$ is responsive to in vitro stimulation with ET-1 [Choudhary E et al, 2005] on both basal and LH-stimulated $\mathrm{P}_{4}$ accumulation. However, in this study we did not observe any effect of LH nor ET-1 over basal $\mathrm{P}_{4}$ accumulation. This discrepancy, as previously described [Sen A et al, 2005] is most likely due to permeabilization protocol used in this study. This interpretation further support the observations of Sen et al [Sen A et al, 2005] where the same permeabilzation procedure was performed and no effect of LH was observed in day-4 luteal steroidogenic cells. However, when cells were incubated with ET-1 and LH the $\mathrm{P}_{4}$ accumulation decreased below basal conditions. This effect can be due to the interactions of LH and ET-1 pathway. Several studies have demonstrated that LH [Alila HW et al, 1989; Davis JS et al, 1996; Flores JA et al, 1998] and ET-1 [Flores JA et al, 1992; Choudhary et al, 2005] activates the PLC $-\mathrm{Ca}^{2+}$-PKC effector system. Infact, in a recent study it was demonstrated that PLC-inhibitor blocked LH stimulated P4 production in primary culture of bovine luteal cells [Nishimura $\mathrm{R}$ et al, 2004]. Thus, it is possible that when the luteal cells were treated with both LH and ET-1, the synergistic effect of both the treatments caused the $\left[\mathrm{Ca}^{2+}\right]_{i}$ to shift from a P4 favorable to a P4 inhibitory level as proposed by Sen et al [Sen et al, 2005]. In contrast, LH or ET-1 treatment alone was unable to shift the $\left[\mathrm{Ca}^{2+}\right]_{\mathrm{i}}$ threshold to $\mathrm{P} 4$ inhibitory condition. This increase in $\left[\mathrm{Ca}^{2+}\right]_{\mathrm{i}}$ caused by $\mathrm{LH}$ and ET-1 treatment may in turn activate the cPKC that lowered the P4 accumulation. In fact, the observation that conventional PKC inhibitor treatment increased the $\mathrm{P}_{4}$ accumulation values back to basal level supports this hypothesis. Less is known about ET-1 availability in vivo in its specific luteal target cells in the early CL. If, indeed ET-1 is available in the early CL, our studies indicate that regulation of $\mathrm{P}_{4}$ accumulation at this stage is independent of PKC $\varepsilon$, but might be via the conventional PKC isozymes.

In day-10 luteal cells LH stimulated $\mathrm{P}_{4}$ accumulation over basal value while ET-1 inhibited this effect. This observation supports previous studies by Sen et al and Choudhary et al [Sen A et al, 2005; Choudhary E et al, 2005]. The difference in the effect of the treatments among the day- 4 and -10 may also be due the sensitivity of the tissue 
as a function of development. The inhibitory effect of ET-1 on LH-stimulated $\mathrm{P}_{4}$ accumulation was antagonized by both conventional and $\mathrm{PKC} \varepsilon$ specific inhibitors. This demonstrates that in contrast to day-4 at this developmental stage PKC $\varepsilon$ is equipotent as conventional PKC isozymes in mediating the inhibitory actions of ET-1 on LHstimulated $\mathrm{P}_{4}$ accumulation. However, whether the actions of PKC $\varepsilon$ are synergistic or additive to that of conventional PKC isozymes need further investigation. We propose that the presence of PKC $\varepsilon$ in addition to conventional PKC isozymes at mid luteal stage shift the balance towards luteal regression.

In summary, the presence of PKC $\varepsilon$ exclusively in steroidogenic cells along with the higher availability of PKC $\varepsilon$ mRNA and protein [Sen A et al, 2004] in the mid-late $\mathrm{CL}$, in contrast to early $\mathrm{CL}$ and its potential regulatory role in LH-stimulated $\mathrm{P}_{4}$ accumulation in the mid-late CL [Sen A et al, 2005], underlines the importance of this isozyme in luteal regression. The differential expression of PKC $\varepsilon$ may be one of the key factors responsible for the sensitivity of the CL to luteal regression. Moreover, the tonic inhibition of $\mathrm{P}_{4}$ accumulation by ET-1 [Choudhary E et al, 2005] in the early CL may be via the conventional PKC isozymes. 


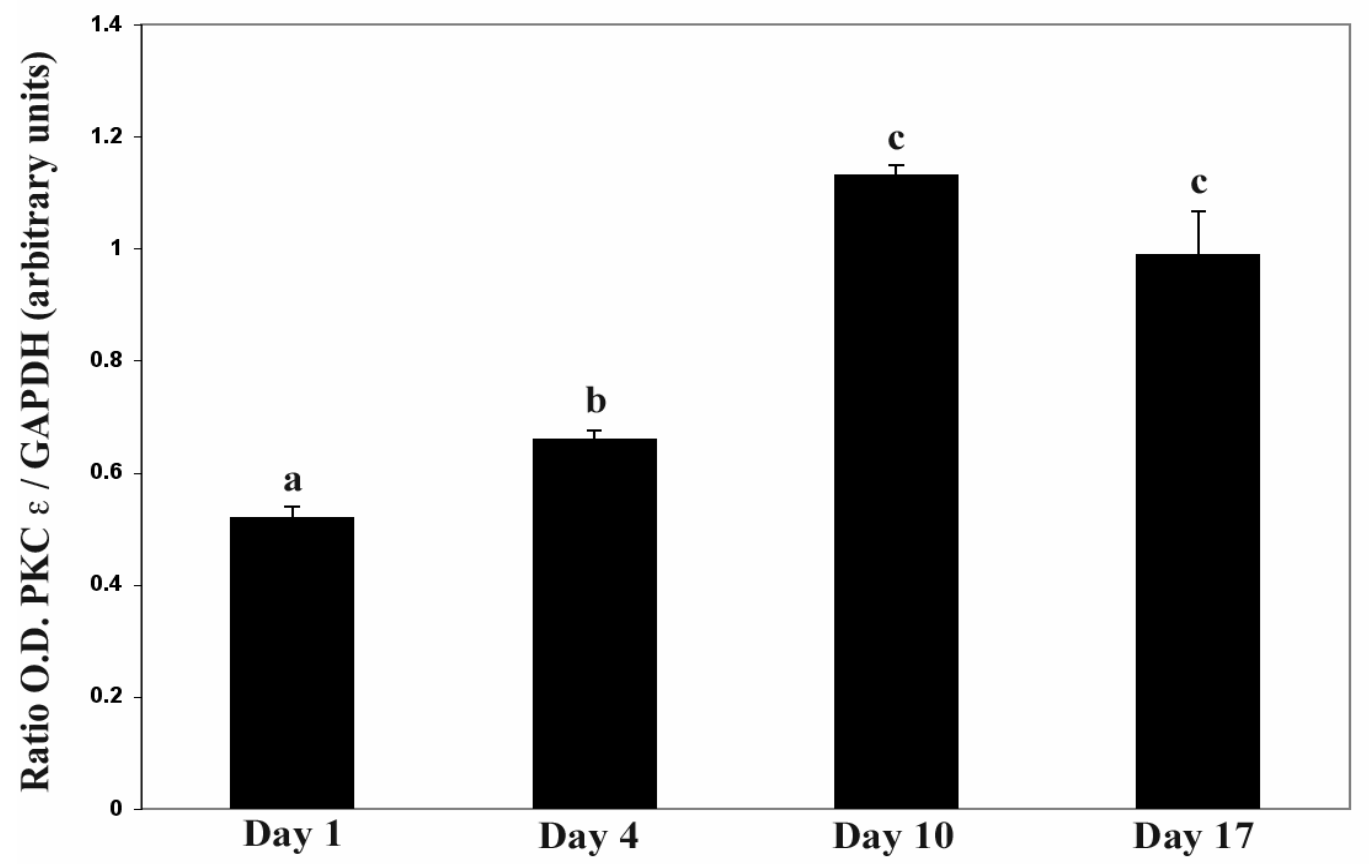

Figure 1A. Semi-quantitative analysis of the amounts of mRNA encoding PKC $\varepsilon$ as a function of luteal development. Total RNA (200 $\mathrm{ng} /$ reaction) isolated from day $1(\mathrm{n}=3)$, day $4(n=3)$, day $10(n=4)$ and day $17(n=3)$ CL were used for the RT-CR assay. Data are presented as the \pm SEM of densitometric analysis of PKC $\varepsilon$ relative to GAPDH mRNA; values with different letters denote statistically significant differences $(\mathrm{P}<0.05)$.

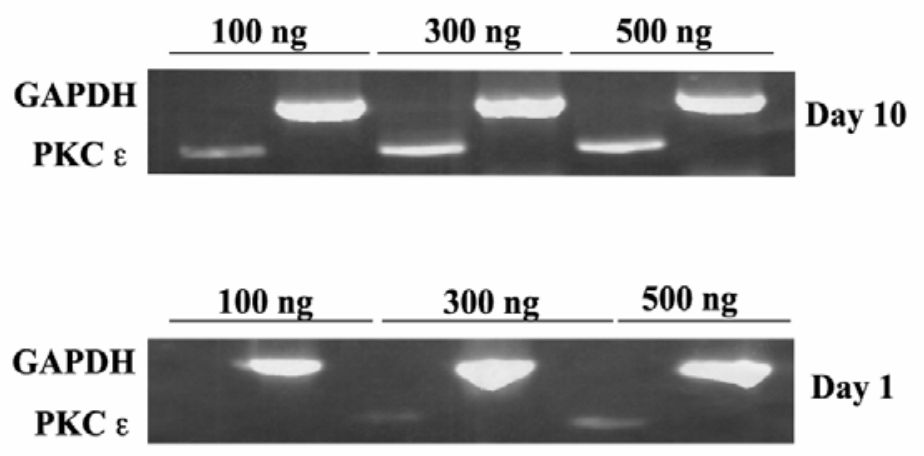

Figure 1B. Representative RT-PCR products obtained by using different amounts of RNA / reaction (100 ng, $300 \mathrm{ng}$ and $500 \mathrm{ng}$ ) isolated from day 1 (lower panel) and day 10 (upper panel) CL using GAPDH and PKC $\varepsilon$ specific primers. The sizes of the amplified products for GAPDH and PKC $\varepsilon$ were 900 and 480 bp, respectively. 


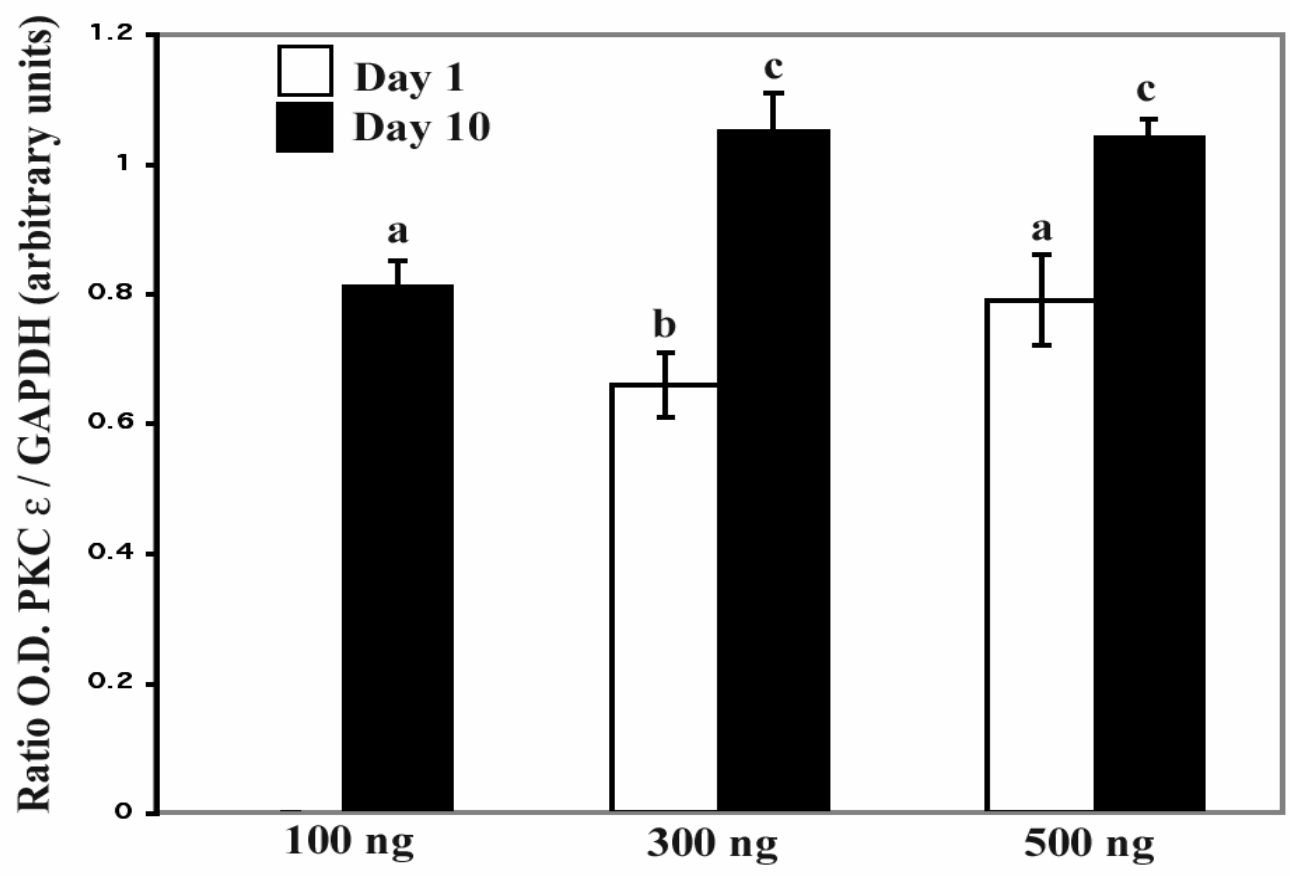

Figure 1C. Semi-quantitative analysis of amplified PKC $\varepsilon$ mRNA as a function of different amounts (100 ng, $300 \mathrm{ng}$ and $500 \mathrm{ng}$ ) of RNA / reaction from day $1(\mathrm{n}=3)$ and day $10 \quad(n=3)$ CL. Data are presented as the \pm SEM of densitometric analysis of PKC $\varepsilon$ relative to GAPDH mRNA; values with different letters denote statistically significant differences $(\mathrm{P}<0.05)$.
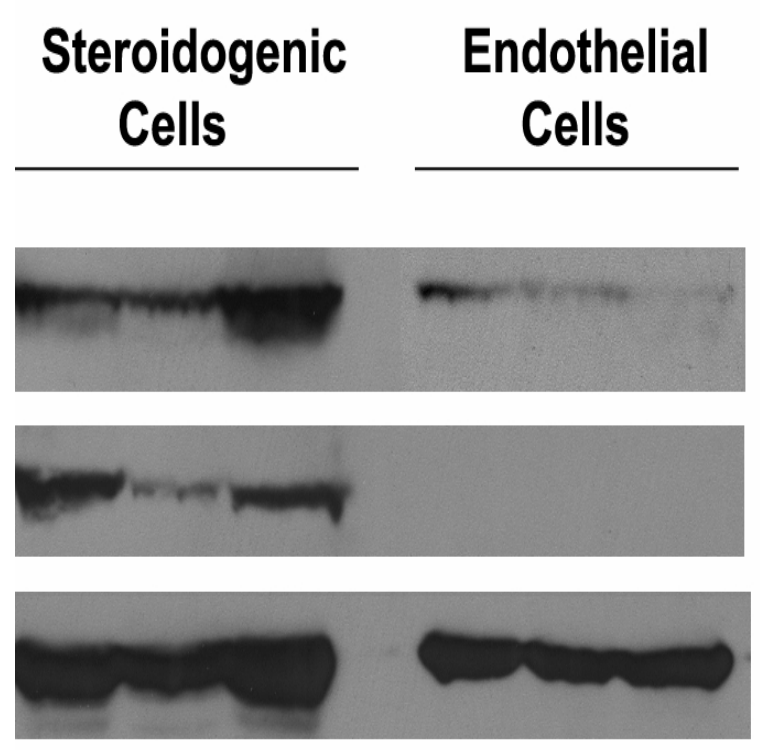

Figure 2A. Representative Western blot of PKC $\alpha$, PKC $\varepsilon$ and actin from enriched

PKC $\alpha$ sterroidogenic and endothelial cells collected from day $10 \mathrm{CL}$ $(\mathrm{n}=3)$. The middle panel reveals PKC \& the exclusive localization of PKC $\varepsilon$ in the steroidogenic cells. $10 \mu \mathrm{g}$

Actin / lane of protein were used for the western blots. Each lane indicates individual CL. 


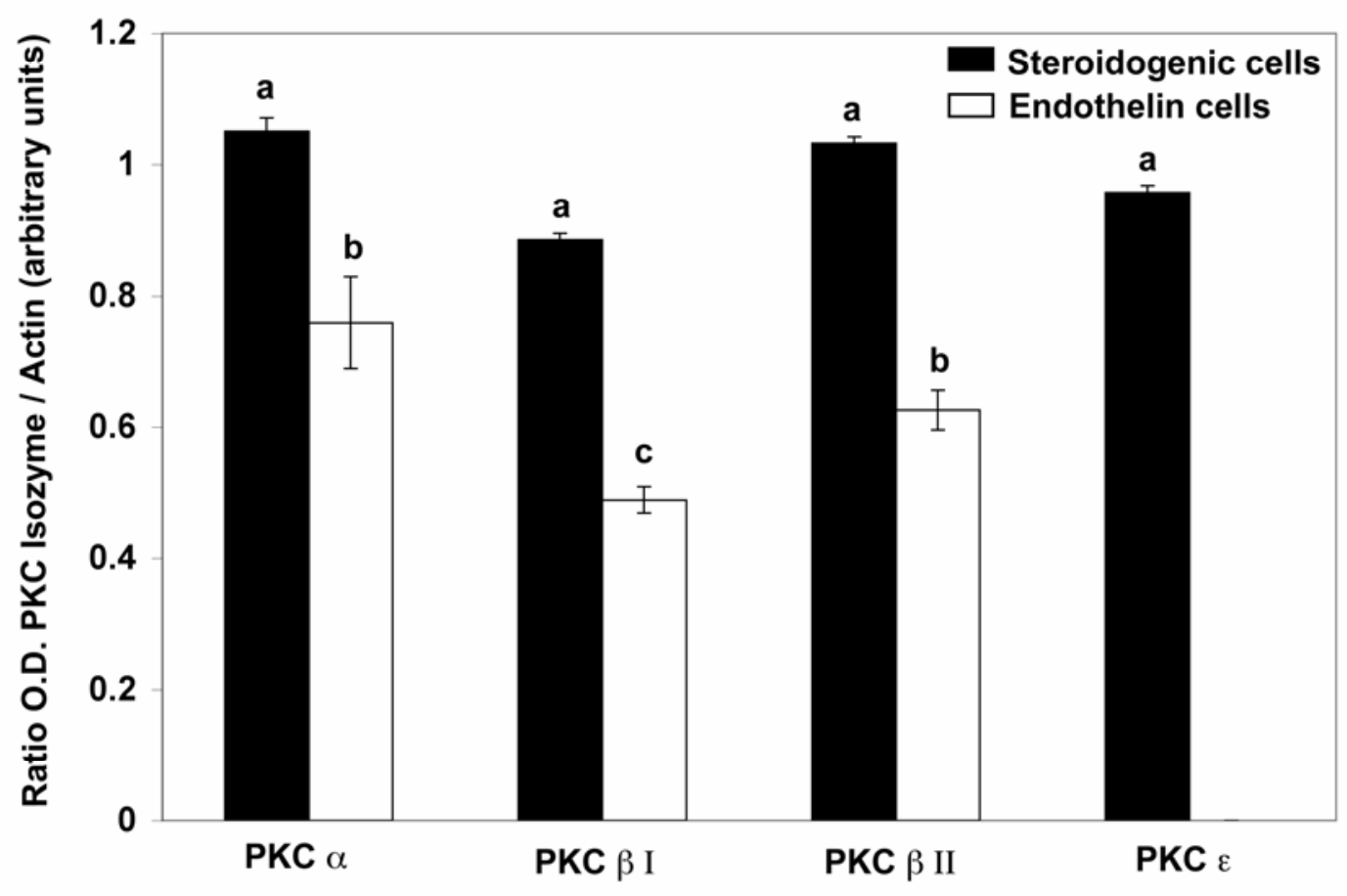

Figure 2B. Semi-quantiative analysis of Western blots to reveal the cellular source of luteal PKC isozymes in day $10 \mathrm{CL}(\mathrm{n}=3)$. The $\mathrm{y}$-axis shows the ratio of optical density (O.D.) of each luteal PKC isozymes corrected by the detected O.D. for its corresponding actin. Data are presented as the \pm SEM; values with different letters denote statistically significant differences $(\mathrm{P}<0.05)$. 

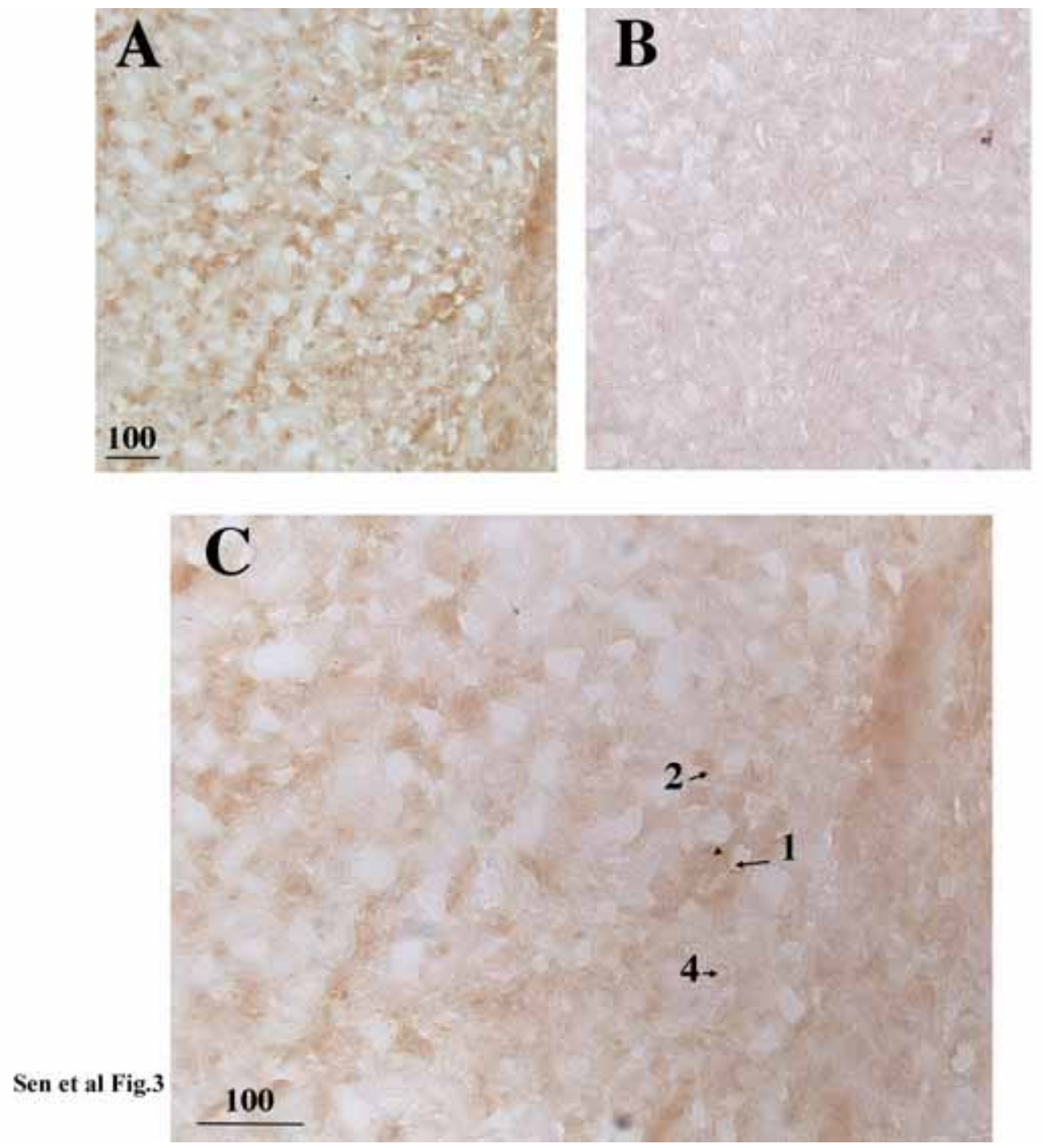

Figure 3. Immunohistological detection of PKC $\varepsilon$ in frozen sections of day $10 \mathrm{CL}$. Panel A is a lower magnification view of the field shown in panel C. Panel B shows a negative control using a consecutive section to that used in panel A but omitting the primary antibody in the detection protocol. The arrow with the number 1 in panel $\mathrm{C}$ indicates EC the in the lumen of blood vessels. The arrow with the number 2 indicates an immunopositive SLC, while the arrowhead represents an immunopositive LLC. The arrow in number 4 represents a LLC that is not stained. Microphotographs shown in panels $\mathrm{A}$ and $\mathrm{B}$ were taken at the same magnification. The bars in panel $\mathrm{A}$ and $\mathrm{C}$ represent $100 \mu \mathrm{m}$. 

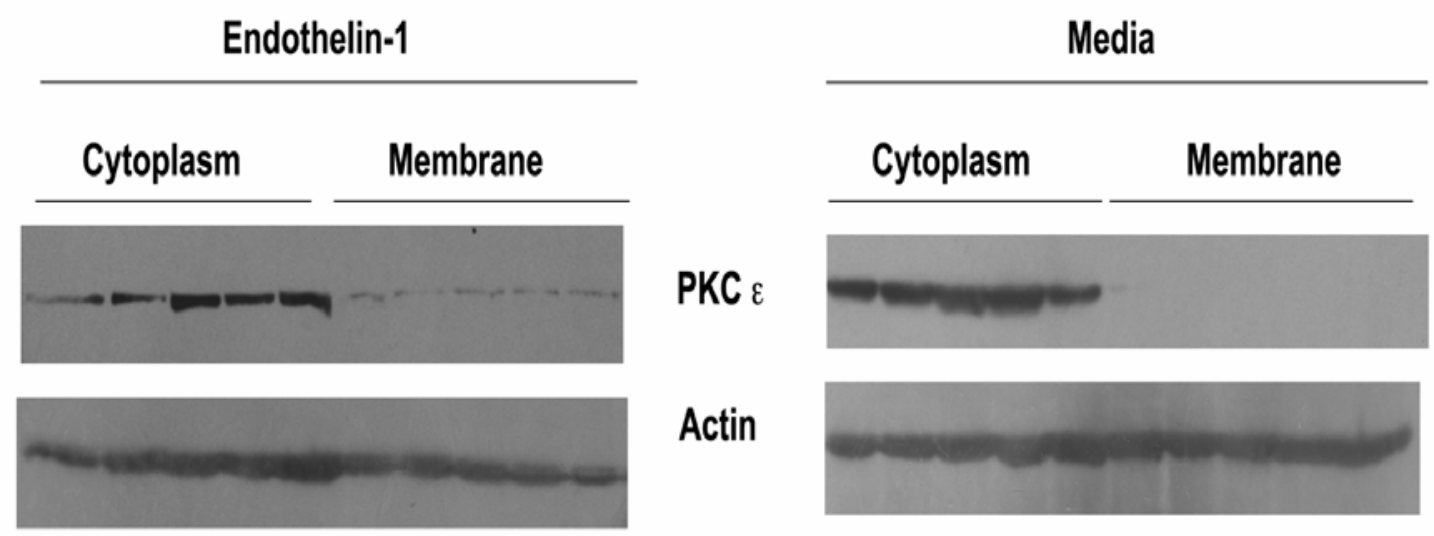

Figure 4A. Representative Western blot demonstrating ET-1 stimulated PKC $\varepsilon$ redistribution in day 10 luteal tissue $(n=5)$. Right top panel shows the exclusive cytoplasmic localization of PKC $\varepsilon$ when the tissue was incubated with control media, MEM-Hepes. Left top panel demonstrates that a 10 min incubation of the luteal tissue with ET-1 $(100 \mathrm{nM})$ induced the appearance of PKC $\varepsilon$ in the membrane fraction. Lower left and right panel show the amount of actin associated with each sample. Each lane indicates individual CL. Amount of protein used for the western blots were $10 \mu \mathrm{g} /$ lane. 


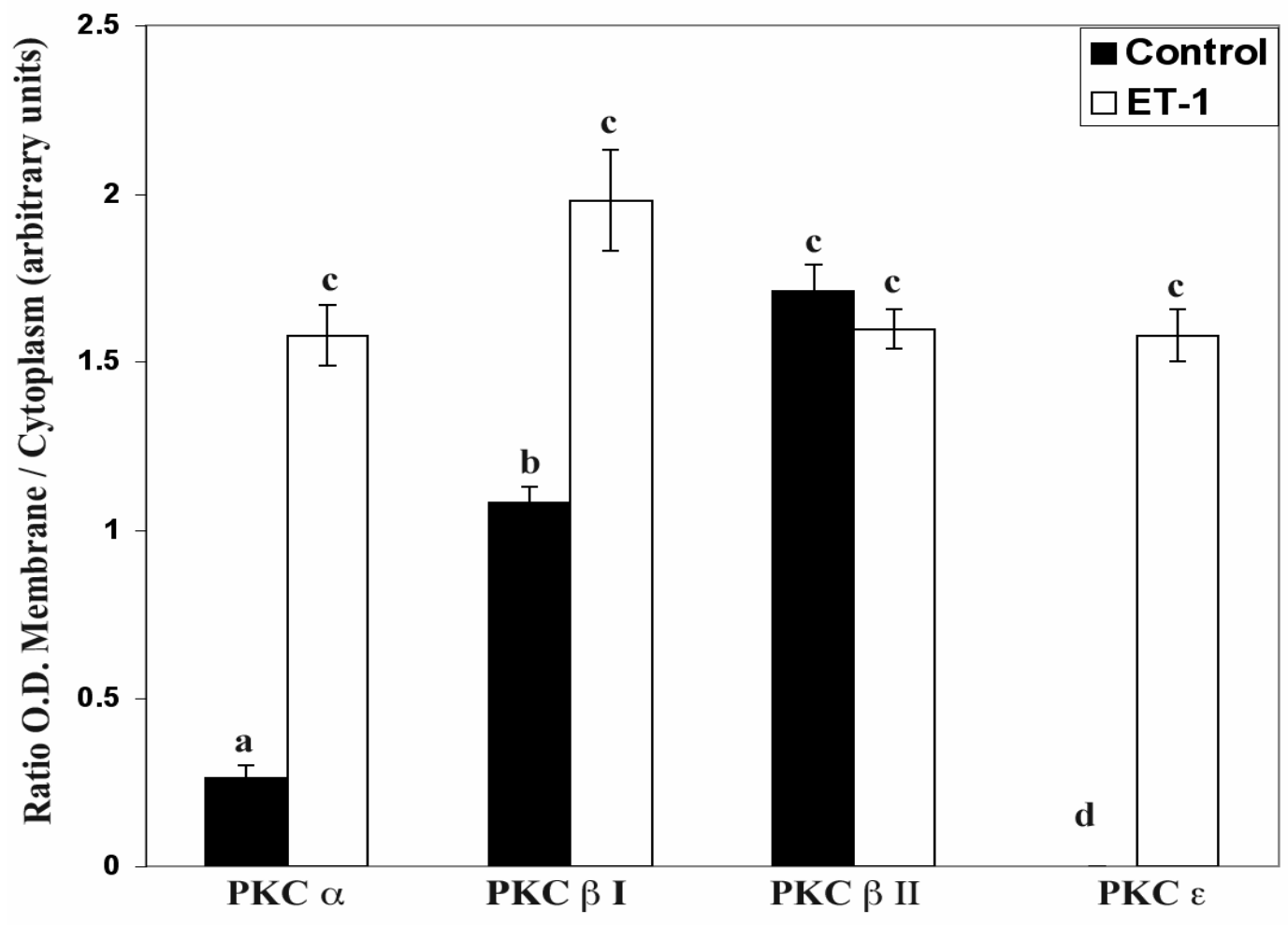

Figure 4B. Semi-quantitative analysis of ET-1 stimulated PKC redistribution. The y-axis represents the actin corrected ratio of the optical density (O.D.) detected for each PKC isozyme in the membrane and cytosolic fractions $(\mathrm{M} / \mathrm{C})$. Data are presented as the \pm SEM; values with different letters denote statistically significant differences $(\mathrm{P}<0.05)$. 


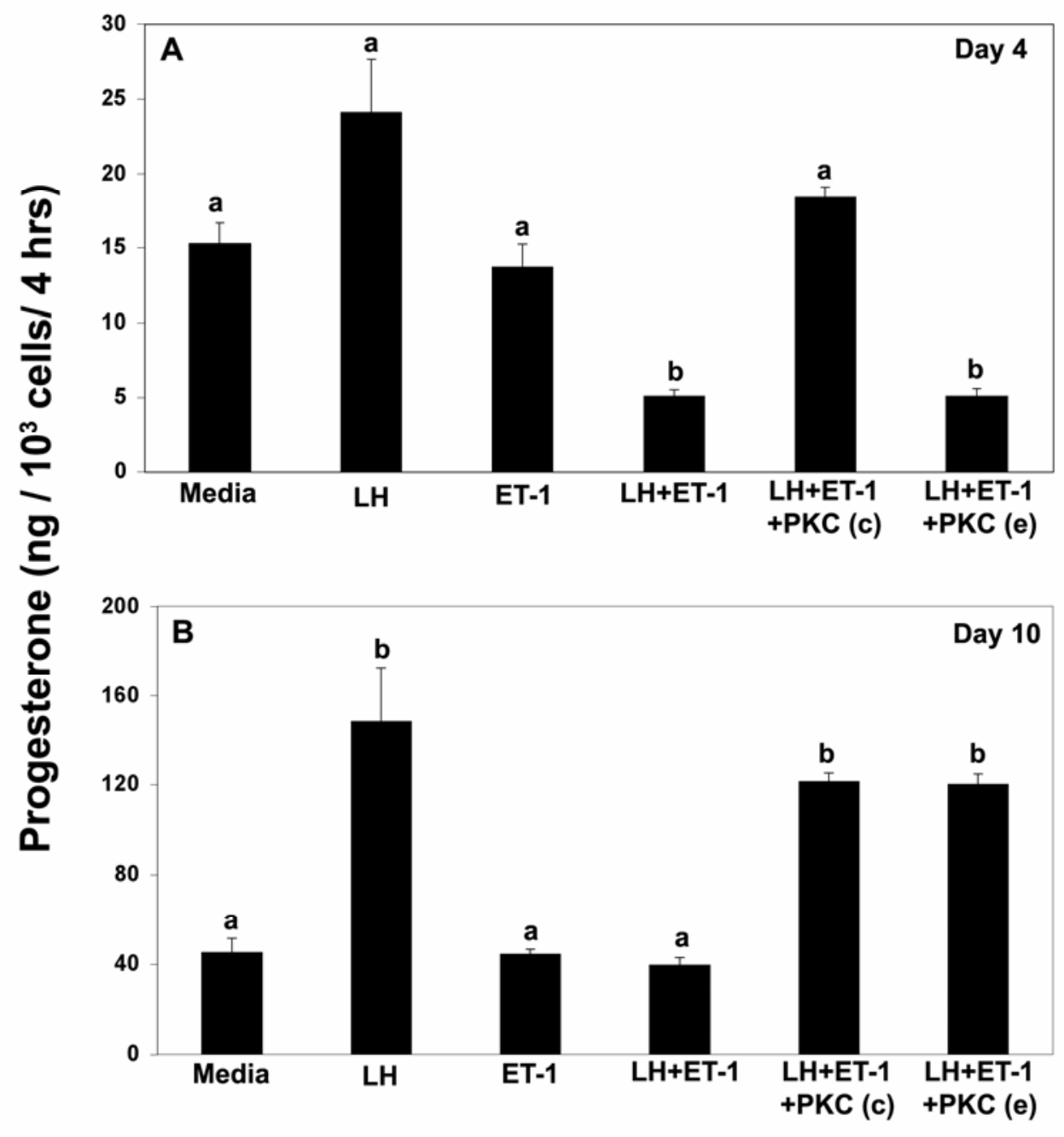

Figure 5. Effects of conventional PKC [PKC (c)] and PKC $\varepsilon$ inhibitors [PKC (e)] on ET$1(100 \mathrm{nM})$ actions on $\mathrm{P}_{4}$ accumulation in cultures of steroidogenic cells collected from (A) Day 4 and (B) Day 10 bovine CL. $\mathrm{P}_{4}$ accumulation was determined in culture media after $4 \mathrm{~h}$ of incubation. Data are presented as the \pm SEM; values with different letters denote statistically significant differences $(\mathrm{P}<0.05)$. 


\section{Chapter VI: Discussion and Future Studies}

These studies were done to investigate the possibility that differences in the intracellular mediators with respect to luteal development might contribute to the relative insensitivity of the early CL towards the luteolytic actions of $\mathrm{PGF}_{2 \alpha}$. The array of PKC isoforms expressed in the early (d-4) and mid-luteal (d-10) phase of the bovine CL include: $\alpha, \beta \mathrm{I}, \beta \mathrm{II}, \varepsilon$ and $\mu$ (chapter 3). More importantly, PKC $\varepsilon$ was expressed differentially expressed and activated as a function of luteal development. Based on these observations it is hypothesized that the differential expression of PKC $\varepsilon$ might be one of the factors responsible for the insensitivity of the early CL. In chapter 4, it was shown that in the mid-late CL, PKC $\varepsilon$ has a regulatory role in the $\mathrm{PGF}_{2 \alpha}$-induced rise in $\left[\mathrm{Ca}^{2+}\right]_{\mathrm{i}}$ and $\mathrm{P} 4$ synthesis. This observation somewhat supports the hypothesis that rise in $\left[\mathrm{Ca}^{2+}\right]_{\mathrm{i}}$ might be a regulating factor for P4 synthesis [Martinez-Zaguilan R et al, 1994; Wegner JA et al, 1991]. In the early CL, a number of studies [Miyamoto A et al, 1993; Hansel W et al, 1991; Choudhary E et al, 2005] have demonstrated that $\mathrm{PGF}_{2 \alpha}$ has luteotropic effects. In the study presented in chapter $4, \mathrm{PGF}_{2 \alpha}$-induced rise in $\left[\mathrm{Ca}^{2+}\right]_{\mathrm{i}}$ in the early luteal phase was lower than the mid CL. The expression of PKC $\varepsilon$ in the mid luteal stage might shift the $\mathrm{PGF}_{2 \alpha}$-induced rise in $\left[\mathrm{Ca}^{2+}\right]_{i}$ from a $\mathrm{P} 4$-favorable to a P4-inhibitory condition. Whether this rise in $\left[\mathrm{Ca}^{2+}\right]_{\mathrm{i}}$ is due to influx or efflux of $\mathrm{Ca}^{2+}$ is unknown and needs further investigation. Furthermore, rise in $\left[\mathrm{Ca}^{2+}\right]_{i}$ is very compartmentalized in cells. Nothing is known about the localization of $\mathrm{PGF}_{2 \alpha}$-induced rise in $\left[\mathrm{Ca}^{2+}\right]_{i}$ within the cell with respect to the sub-cellular localization of PKC isozymes at different developmental stages of the CL.

The exclusive expression of PKC $\varepsilon$ in the luteal SC, as reported in chapter 5, further indicates an important role of this isoform in the regulation of rise in $\left[\mathrm{Ca}^{2+}\right]_{\mathrm{i}}$. In $\mathrm{SC}$, $\mathrm{PGF}_{2 \alpha}$ [Chapter 4; Choudhary E et al, 2005] and ET-1[Choudhary et al, 2005] induced greater rises in $\left[\mathrm{Ca}^{2+}\right]_{\mathrm{i}}$ in the mid-luteal phase than in the early stage. In contrast, in EC, $\mathrm{PGF}_{2 \alpha}$ and ET-1 induced rises in $\left[\mathrm{Ca}^{2+}\right]_{\mathrm{i}}$ were equal in both developmental stages [Choudhary E et al, 2005]. This might be due to the absence of PKC $\varepsilon$ in the EC. The study in chapter 5 demonstrated the ability of ET-1 to activate PKC isoforms in the mid 
luteal phase. In addition, Choudhary et al [Choudhary E et al, 2005] reported that ET-1 can elicit rises in $\left[\mathrm{Ca}^{2+}\right]_{\mathrm{i}}$ in both SC and EC. These observations indicate that ET-1, like $\mathrm{PGF}_{2 \alpha}$ utilizes, at least in part, the PLC effector system with PKC and calcium as intracellular mediators. Whether ET-1 also activates other intracellular mediators is still unclear. In the bovine CL, both ETA and ETB receptors are expressed throughout the estrous cycle [Meidan R et al, 2002, Choudhary E et al, 2005]. However, very little is known about the ETB receptor. It is possible that these two endothelin receptors are linked to different effector systems that induce diverse physiological responses during luteal regression.

Choudhary et al [Choudhary et al, 2005] proposed that ET-1 is a tonic inhibitor of P4 accumulation rather than a mediator of the luteolytic action of $\mathrm{PGF}_{2 \alpha}$. The study in chapter 5 further demonstrated that tonic inhibition of ET-1 on P4 accumulation might be via the $\mathrm{cPKC}$ isozymes. An interesting observation in this study was that when luteal SC were incubated with ET-1 and $\mathrm{LH}$, the $\mathrm{P}_{4}$ accumulation decreased below basal conditions. In contrast, LH or ET-1 treatment alone had no effect on P4 accumulation. This effect can be due to the interactions of LH and ET-1 pathways. Several authors have demonstrated that LH [Alila HW et al, 1989; Davis JS et al, 1996; Flores JA et al, 1998] and ET-1 [Flores JA et al, 1992; Choudhary et al, 2005] activate the PLC - $\mathrm{Ca}^{2+}$-PKC effector system. Also, it has been demonstrated that PLC-inhibitor blocked LHstimulated P4 production in primary cultures of bovine luteal cells [Nishimura R et al, 2004]. Thus, it is possible that when the luteal cells were treated with both LH and ET-1, the synergistic effect caused the rise in $\left[\mathrm{Ca}^{2+}\right]_{\mathrm{i}}$ to shift from a P4-favorable to a P4inhibitory status as proposed in chapter 4. In contrast, LH or ET-1 treatment alone was unable to shift the rise in $\left[\mathrm{Ca}^{2+}\right]_{\mathrm{i}}$ threshold to P4-inhibitory conditions. The increase in $\left[\mathrm{Ca}^{2+}\right]_{\mathrm{i}}$ caused by LH and ET-1 treatment might in turn, activate the cPKC that lowered the P4 accumulation. In the early CL, very little is known about ET-1 availability in its specific luteal target cells. Indeed, if ET-1 is available in the early CL, this study indicated that regulation of $\mathrm{P}_{4}$ accumulation at this stage is independent of PKC $\varepsilon$, but might be via the conventional PKC isozymes. 
The role of the conventional PKCs in regulation of luteal regression is poorly understood. Wu et al [Wu et al, 2001] demonstrated that only in the mid-late LLC, PKC $\alpha$ and $\beta$ acting on E-box DNA elements specifically increased Cox-2 transcription. However, they failed to explain possible reasons for differential expression of Cox-2 by cPKCs. The cPKCs are expressed and activated in both early and mid luteal phase (chapter 3). Thus, the differential expression of Cox-2 by cPKCs is not due to the unavailability of cPKCs. PKC activates a large number of different transcription factors [Ray A et al, 2000]. It is likely that PKC $\alpha$ and $\beta$ activate a TF that acts on E-box DNA elements present in the Cox-2 promoter region, thereby causing Cox-2 expression. It is possible that, expression of such a TF only in the mid-late $\mathrm{CL}$ might result in $\mathrm{cPKC}$ induced differential expression of Cox-2 gene. Further investigation is required to identify the physiological roles of cPKCs involved in luteal regression.

In EC, presence of FP is controversial. Mamluk et al [Mamluk R et al, 1998] have shown the presence of FP mRNA in EC. Moreover, Choudhary et al [Choudhary E et al, 2005] demonstrated that EC exhibited a rise in $\left[\mathrm{Ca}^{2+}\right]_{i}$ when treated with $\mathrm{PGF}_{2 \alpha}$. Both these studies were performed with bovine primary EC culture models. In contrast, other studies with EC failed to detect $\mathrm{FP}$ or $\mathrm{PGF}_{2 \alpha}$-responsive intracellular signaling pathways [Cavicchio VA et al, 2002; Chen DB et al, 1998]. These studies used a commercially available bovine-CL-derived microvascular EC called CLENDO cells. It is possible that these CLENDO cells have morphological differences such that the normal EC or FP expression in these cells has been lost during cell preparation. In order to address this controversy, better characterization of the CLENDO cells is needed. On the other hand, immunohistochemical studies using FP specific antibodies and $\mathrm{PGF}_{2 \alpha}$ binding studies on EC are required to support the presence of FP. In bovine CL, there might be two types of EC; cytokeratin positive and cytokeratin negative [Spanel-Borowski K and Fenyves A, 1994a; Spanel-Borowski K et al, 1994b; Spanel-Borowski K et al, 1990]. It is possible that these two EC cell types differ in their expression of FP [Aust BEG et al, 1999; Lehmann I et al, 2000].

In bovine luteal tissue, the mechanisms by which $\mathrm{PKC}$-calcium pathway regulates P4 synthesis are unclear. Studies have shown that calcium and PKC regulate PLA2 and 
arachidonic acid release [Chang TM et al, 1999; Zor U et al, 1991; Wiltbank MC et al, 1989b; Wiltbank MC et al, 1989a; Wu XM et al, 1990; Tsai SJ et al, 2001; Wiltbank MC et al 2003]. It is possible that $\mathrm{Ca}^{2+}$ and $\mathrm{PKC}$ isoforms might regulate gene expression or/and activity of PG metabolic enzymes during distinct luteal stages and that this may lead to luteal maintenance or demise. In bovine luteal cells [Chen DB et al, 1998; Chen D et al, 2001] it has been demonstrated that PKC activates MAPK pathway, in turn regulates gene expression. Similarly, calcium is known to regulate gene expression via calcium-calmodulin pathway [Wu KK, 2002]. Moreover, calcium [Srivastava AK et al, 1980] and protein kinases [Jiang $\mathrm{G}$ et al, 2003] are known to regulate enzymatic activity. In the bovine and ovine CL, StAR activity can be modulated by PKA/PKC phosphorylation [Niswender GD et al, 2000]. Studies have shown that expression of StAR can be regulated by PKA/PKC via DAX-1/SF-1 nuclear receptors in other species [Christenson LK et al, 1998; Hammer GD et al, 1999; Ito M et al, 1998; Zazopoulos E et al, 1997]. In bovine luteal cells, the regulation of StAR expression and activity and the $\mathrm{PKC}$ isoforms involved in this process are poorly understood. Because of the complexity involved in regulation of luteal regression, DNA microarray and proteomic techniques may provide insight in relation to the different stages of luteal development. Furthermore, overexpression and gene ablation studies of PKC $\varepsilon$ will help to elucidate the mechanism of early luteal insensitivity.

In summary, these studies depict the complexity involved in the process of luteal regression. The regulation of luteal regression involves interactions among different factors, intracellular mediators and signaling pathways resulting in differential expression and activation and/or inactivation of a number of proteins. It is proposed that the differential expression and activation of PKC $\varepsilon$ as a function of development may be one of the several factors responsible for the insensitivity of the early CL. Expression of PKC $\varepsilon$ in the mid-luteal phase shifts the $\mathrm{PGF}_{2 \alpha}$-induced rise in $\left[\mathrm{Ca}^{2+}\right]_{\mathrm{i}}$ from a P4-favorable to a P4-inhibitory condition. Based on these observations, it is hypothesized that the insensitivity of the early CL towards the luteolytic actions of $\mathrm{PGF}_{2 \alpha}$ might be due to differences in the intracellular mediators with respect to luteal development. 


\section{References}

1. Acosta TJ, Berisha B, Miwata K, Kobayashi S, Ozawa T, Hayashi K, Schams D, Miyamoto A. Atrial natriuretic peptide system in the bovine CL. Biol Reprod 62(suppl 1):211(abstract 264), 2000.

2. Acton S, Rigotti A, Landschilz KT, Xu S, Hobbs HH, Krieger M. Identification of scavenger receptor SR-BI as a HDL receptor. Science 271:518-520, 1996.

3. Adashi EY, Resnick CE, Packman JN, Hurwitz A, Payne DW. Cytokine-mediated regulation of ovarian function: TNF- $\alpha$ inhibits gonadotropin supported progesterone accumulation by differentiating and luteinized murine granulose cells. Am J Obset Gynecol 162:889-899, 1990.

4. Agudo SPL, Zahler WL, Smith MF. Effects of $\mathrm{PGF}_{2 \alpha}$ on the adenylate cyclase and phosphodiesterase activity of ovine corpora lutea. J Anim Sci 58:955-962, 1984.

5. Akaishi T, Sakuma Y. Estrogen excites oxytocinergic but not vasopressinergic cells in the paraventricular nucleus of female rat hypothalamus. Brain Res 335:302-305, 1985.

6. Akita Y. Protein kinase C- $\varepsilon(\mathrm{PKC}-\varepsilon)$ : its unique structure and function. J Biochem 132:847-852, 2002.

7. Albarracin CT, Parmer TG, Duan WR, Nelson SE, Gibori G. Identification of a major prolactin-regulated protein as $20 \alpha$-hydroxysteroid dehydrogenase: coordinate regulation of its activity, protein content and mRNA expression. Endocrinology 34:2453-60, 1994.

8. Alila HW, Davis JS, Dowd JP, Corradino RA, Hansel W. Differential effects of calcium on progesterone production in small and large bovine luteal cells. J Steroid Biochem 36:687-693, 1990.

9. Alila HW, Corradino RA, Hansel W. Differential effects of LH on intracellular free calcium in small and large bovine luteal cells. Endocrinology 124:2314-2320, 1989. 
10. Alila HW, Corradino RA, Hansel W. A comparison of the effects of cyclooxygenase prostanoids on $\mathrm{P} 4$ production by small and large bovine luteal cells. Prostaglandins 36:259-270, 1988a.

11. Alila HW, Dowd J, Corradino RA. Role of calcium in P4 synthesis by small and large bovine luteal cells. 21 Annual Meeting of SSR, Seattle WA, p55 (Abstract), $1988 b$.

12. Alila HW, Dowd JP, Corrandino RA, Harris WV, Hansel W. Control of progesterone production in small and large bovine cells separated by flow cytometry. J Reprod Fertil 82:645-655, 1988c.

13. Alila HW, Hansel W. Origin of different cell types in the bovine CL as characterized by specific monoclonal antibodies. Biol.Reprod 31:1015-1025, 1984.

14. Amico JA Richardsin DW, Winters SJ. Effect of gonadal steroids upon hypothalamic oxytocin expression. Adv Exp Med Biol 395:23-36, 1995.

15. Amselgruber W, Sinowatz F, Schams D, Skottner A. Immunohistochemical aspects of IGF I and II in the bovine CL. J Reprod Fertil 101:445-451, 1994.

16. Anderson LE, WU, YL, Tsai SJ, Wiltbank MC. PGF ${ }_{2 \alpha}$ receptor in the CL: Recent information on the gene, mRNA and protein. Biol Reprod 64:1041-47, 2001.

17. Arai H, Hori S, Aramori I, Ohkubo H, Nakanishi S. Cloning and expression of a cDNA encoding an endothelin receptor. Nature 348:730-732, 1990.

18. Arakane F, King SR, Du Y, Kallen CB, Walsh LP, Watari H Stocco DM, Strauss JF. Phosphorylation of StAR protein modulates its steroidogenic activity. J Biol Chem 272:32656-662, 1997.

19. Arakane F, Sugawara T, Nishino H, Liu Z, Holt HA, Pain D, Stocco DM, Miller WL, Strauss JF. StAR protein retains activity in the absence of its mitochondrial import sequence: implications for the mechanism of StAR action. PNAS 93: 13731-36, 1996.

20. Aramori I, Nakanishi S. Coupling of two endothelin receptor subtypes to differing signal transduction in transfected Chinese hamster ovary cells. JBC 267:12468$74,1992$. 
21. Argetsinger LS, Cambell GS, Yang X, Witthuhn BA, Silvennoinen O, Ihle JN, Carter-Su C. Identification of JAK2 as a GH receptor associated tyrosine kinase. Cell 74:237-244, 1993.

22. Armstrong DT, Hansel W. Alteration of the bovine estrous cycle with oxytocin. J Dairy Sci 42:533-542, 1959.

23. Arosh J, Banu SK, Chapdelaine P, Fortier MA. Temporal and tissue specific expression of prostaglandin receptors EP2, EP3, EP4, FP and COX 1 and 2 in uterus and fetal membranes during bovine pregnancy. Endocrinology 145:407-17, 2004a.

24. Arosh JA, Banu SK, Chapdelaine P, Madore E, Sirois J, Fortier MA. Prostaglandin biosynthesis, transport and signaling in CL: A basis for autoregulation of luteal function. Endocrinology 145:2551-60, 2004b.

25. Arosh JA, Banu SK, Chapdelaine P, Emond V, Kim JJ, MacLaren LA, Fortier MA. Molecular cloning and characterization of bovine prostaglandin E2 receptors EP2 and EP4: expression and regulation in endometrium and myometrium during estrous cycle and early pregnancy. Endocrinology 144:3076-3091, 2003.

26. Arosh JA, Parent J, Chapdelaine P, Sirois J, Fortier MA. Expression of Cox-1 and 2 and prostaglandin synthase in bovine endometrial tissue during the estrous cycle. Biol Reprod 67:161-169, 2002.

27. Asselin E, Fortier MA. Detection and regulation of the messenger for a putative bovine endometrial 9-keto-prostaglandin E reductase: effect of oxytocin and interferon tau. Bio Reprod 62: 125-131, 2000.

28. Aust G BE, Lehman R, Kiessling S, Spanel-Borowski K. Different cytokine adhesion molecule and prostaglandin receptor (PG-R) epression by cytokeratin 18 negative $(\mathrm{CK}-)$ and positive $(\mathrm{CK}+)$ endothelial cells $(\mathrm{EC})$. Basic Res Cardiol 94:406, 1999.

29. Avvakumov GV, Krupenko SA, Strel'chyonok OA. Study of the transcortin binding to human endometrium plasma membrane. Biochim Biophys Acta 984(2):143-50, 1989. 
30. Bacon C, Keator C, Milvae R, McCracken J. Effect of depleting luteal oxytocin (OT) on pregnancy rates in sheep. abstracts.co.allenpress.com/pweb/ssr2004/document/?ID=45923.

31. Badr KF, Murray J, Breyer MD, Takahashi K, Inagami T, Harris RC. Mesangial cells, glomerular and renal vascular responses to endothelin in the rat kidney. Elucidation of the signal transduction pathays. J Clin Invest 83:336-342, 1989.

32. Bagavandoss P, Wilks JW. Isolation and characterization of microvascular endothelial cells from the developing CL. Biol Reprod 44:1132-39, 1991.

33. Banu SK, Arosh JA, Chapdelaine P, Fortier MA. Expression of PG transporter in the bovine uterus and fetal membranes during pregnancy. BOR (in press). DOI: 10.1095/biolreprod.105.039925, April 62005.

34. Banu SK, Arosh JA, Chapdelaine P, Fortier MA. Molecular cloning and spatiotemporal expression of PG transporter: A basis for the action of PGs in the bovine reproductive system. PNAS 100:11747-11752, 2003.

35. Bao B, Garverick HA. Expression of steroidogenic enzyme and gonadotropin receptor genes in bovine follicles during ovarian follicular waves. A review. J.Anim.Sci 76:1903-21, 1998.

36. Barcikowski B, Carlson JC, Wilson L, McCracken JA. The effect of endogenous and exogenous estradiol-17 $\beta$ on the release of prostaglandin F2 $\alpha$ from the ovine uterus. Endocrinology 95:1340-1349, 1974.

37. Barker S, Khan NQ, Wood EG, Corder R. Effect of an antisense oligonucleotide to ECE-1c on ECE-1c mRNA, ECE-1 protein and ET-1 synthesis in bovine pulmonary artery smooth muscle cells. Mol Pharm 59: 163-169, 2001.

38. Baum MS, Rosberg S. A phorbol ester, phorbol 12-myristate 13-acetate, and calcium ionophore, A23187, can mimic the luteolytic effect of prostaglandin F2 alpha in isolated rat luteal cells. Endocrinology 120:1019-1026, 1987.

39. Beard J. The span of gestation and the cause of birth: a study of the critical period and its effects in mammalia. Jena, Germany: Fischer, 1897.

40. Beaver CJ, Mudroch WJ. Ovarian and uterine prostaglandin E2-9- ketoreductase activity in the cyclic and pregnant ewe. Prostaglandins 44:37-42, 1992. 
41. Benyo DF, Pate JL. TNF- $\alpha$ alters bovine luteal cell synthetic capacity and viability. Endocrinology 130: 854-860, 1992.

42. Berisha B, Schams D, Miyamoto A. The expression of angiotensin and endothelin system members in the bovine CL during estrus cycle and pregnancy. Endocrine 19:305-312, 2002.

43. Berisha B, Schams D, Kosmann M, Amselgruber W, Einspanier R. Expression and tissue concentration of VEGF, its receptors and localization in the bovine CL during estrous cycle and pregnancy. Biol.Reprod 63:1106-14, 2000.

44. Bird GS, Rossier MF, Obie JF, Putney JW Jr. Sinusoidal oscillation in intracellular calcium requiring negative feedback by PKC. J Biol Chem 268:8425-8428, 1993.

45. Bissonnette M, Tien XY, Niedziela SM, Hartmann SC, Frawley BP Jr, Roy HK, Sitrin MD, Perlman RL, Brasitus TA. 1,25(OH)2 vitamin D 3 activates PKC $\alpha$ in CaCo-2 cells: a mechanism to limit steroid induced rise in $\left[\mathrm{Ca}^{2+}\right]_{\mathrm{i}}$. Am J Physiol Gastrointest Liver Physiol 267:G465-G475, 1994.

46. Blair RM, Saatman R, Liou SS, Fortune JE, Hansel W. Roles of leukotrienes in bovine CL regression: an in vivo microdialysis study. Proc Soc Med Biol Med 216:72-80, 1997.

47. Blaustein JD, Tetal MJ, Meredith JM. Neurobiological regulation of hormone response by progestin and estrogen receptors. In: Neurobiological effects of sex steroid hormones, edited by Micevyvh $\mathrm{P}$ and Hammer R. Cambridge, UK:Cambridge Uni Press, p324-349, 1995.

48. Blumberg PM. Complexities of the protein kinase $\mathrm{C}$ pathway. Mol Carcinogen 4: 339-344, 1991.

49. Bode HP, Goke B. Protein kinase C activates capacitative calcium entry in the insulin secreting cell line RINm5F. FEBS Lett 339:307-311, 1994.

50. Boney RC, Qizilbash ST, Franks S. Endometrial $\mathrm{CPLA}_{2}$ enzymes and their regulation by steroid hormones. Steroid Biochem 27:1057-64, 1987.

51. Bonnin P, Huynh L, L'Haridon R, Chene N, Martal J. Transport of uterine PGF2 alpha to the ovaries by systemic circulation and local lymphovenous-arterial diffusion during luteolysis in sheep. J Reprod Fertil 116(1):199-210, 1999. 
52. Borner C, Ueffing M, Jaken S, Parker JP, Weinstein IB. Two closely related isoforms of protein kinase $\mathrm{C}$ produce reciprocal effects on the growth of rat fibroblasts. J Biol Chem 270:78-86, 1995.

53. Bose H, Lingapp VR, Miller WL. Rapid regulation of steroidogenesis by mitochondrial protein import. Nature 417:87-91, 2002.

54. Boshier DP, Holloway H, Millener NM. Triacylglycerols in the rat uterine epithelium during the oestrous cycle and early pregnancy. J Reprod Fertil 62:441446, 1981.

55. Boshier DP, Holloway H. Effects of ovarian steroid hormones on histochemically demonstrated lipids in the rat uterine epithelium. J Endocrinol 56:59-67, 1973.

56. Boujard N, Hudson JR, Papadopoulus V. Inhibition of hormone stimulated steroidogenesis in cultured Leydig tumor cells by cholesterol-linked phosphorothioate oligonucleotide antisense to diazepam-binding inhibitor. PNAS 90:5728-31, 1993.

57. Braden TD, Gamboni F, Niswender GD. Effects of PGF2 $\alpha$ induced luteolysis on the populations of cells in the ovine CL. Biol Reprod 39:245-253, 1988.

58. Brown MS, Goldstein JL. A receptor mediated pathway for cholesterol homeostasis. Science 232:34-47, 1986.

59. Burns PD, Graf GA, Hayes SH, Silvia WJ. Mechanisms by which oxytocin stimulates uterine PGF2 alpha synthesis in bovine endometrium: roles of PLC and A2. Domet. Anim. Endocrinol 14:181-191, 1997.

60. Burton RM, Harding GB, Rust N, Westphal U. Steroid protein interactions. XXIII. Nonidentity of corticol-binding globulin and P4-binding globulin in guinea pig. Steroids 17:1-16, 1971.

61. Butenandt A, Westphal U.Zur isolierung und charak-terisierung des corpus luteum hormons. Berichte Deutsch. Chem. Gesrilsch 67:1440-1442, 1934.

62. Cadwell JD, Brooks PJ, Jirikowski GF, Barakat AS, Lund PK, Pederson CA. Estrogen alters oxytocin mRNA levels in the preoptic area. J Neuroendocrinol 1:273-228, 1989. 
63. Caffrey JL, Fletcher PW, Diekman MA, O’Callaghan PL, Niswender GD. The activity of ovine luteal cholesterol esterase during several experimental conditions. Biol Reprod 21:601-608, 1979.

64. Carla M, Ribeiro P, Putney JW Jr. Differential effects of PKC activation on calcium storage and capacitative calcium entry in NIH 3T3 cells. J Biol Chem 271:21522-21528, 1996.

65. Carlsson B, Nilsson A, Isaksson OGP, Billig H. GH-receptor mRNA in the rat ovary: regulation and localization. Mol Cell Endocrinol 95:59-66, 1993.

66. Carmeliet P, Ferrira V, Breir G, Pollefeyt S, Kieckens L. Abnormal blood vessel development and lethality in embryos lacking a single VEGF allele. Nature 380:435-439, 1996.

67. Carswell EA, Old LJ, Kassel RL, Green S, Fiore N, Williamson B. An endotoxininduced serum factor that causes necrosis of tumors. PNAS 72:3666-70, 1975.

68. Cary NC. Statistical software for the Apple Macintosh. JMP Statistics and Graphics Guide, Version 3.0 of JMP; Statistical Analysis System Institute, Inc, 1994.

69. Casida LE. Research techniques in physiology of reproduction in the female. In: Chapman AB (ed.), Techniques and Procedures in Animal Production Research. Albany, NY: American Society of Animal Production: 106-121, 1959.

70. Castracane VD, Jordan VC. The effect of estrogen and progesterone on uterine prostaglandin biosynthesis in the ovariectomized rat. Bio Reprod 13:587-596, 1975.

71. Cavicchio VA, Pru JK, Davis BS, Davis JS, Rueda BR, Townson DH. Secretion of monocyte chemoattractant protein-1 by endothelial cells of the bovine CL: regulation by cytokines but not $\mathrm{PGF}_{2 \alpha}$. Endocrinology 143:3582-89, 2002.

72. Chaffkin LM, Luciano AA, Peluso JJ. The role of progesterone in regulating human granulosa cell proliferation and differentiation in vitro. J Clin Endocrinol Metab 76:696-700; 1993.

73. Chakravorty A, Joslyn MI, Davis JS. Characterization of insulin and IGF-1 actions in the bovine luteal cells: regulation of receptor tyrosine kinase activity, PI-3 kinase and DNA synthesis. Endocrinology 133:1331-1340, 1993. 
74. Challis JR, Sloboda DM, Alfaidy N Lye SJ, Gibb W, Patel FA, Whittle WL, Newnham JP. Prostaglandins and mechanisms of preterm birth. Reproduction 124:1-17, 2002.

75. Chandrasekharan NV, Dai H, Roos KLT, Evanson NK, Tomsik J, Elton TS, Simmons DL. Cox-3, a cyclooxygenase-1 variant inhibited by acetaminophen and other analgesic/antipyretic drugs: Cloning, structure and expression. PNAS 99:13926-31, 2002.

76. Chang Q, Tepperman BL. Effects of selective PKC isoform activation and inhibition of TNF- $\alpha$ induced injury and apoptosis in human intestinal epithelial cells. Br J Pharmacol 140:41-52, 2003.

77. Channing CP. Steroidogenesis and morphology of the human ovarian cell types in tissue culture. J Endocrinology 45:297-308, 1969a.

78. Channing CP. Tissue culture of equine ovarian cell types: culture methods and morphology. J Endocrinology 43:381-890,1969b.

79. Chegini N, Lei ZM, Rao CV, Hansel W. Cellular distribution and cycle phase dependency of gonadotropin and eicosanoid binding sites in bovine CL. Biol Reprod 45:506-513, 1991.

80. Chegini NZ, Lei M, Rao CV. Cellular distribution of prostacyclin synthase and specific prostacyclin binding sites in bovine CL of pregnancy. Mol Cell Endocrinol 71:133-140, 1990.

81. Chen DB, Fong HW, Davis JS. Induction of c-fos and c-jun mRNA expression by $\mathrm{PGF}_{2 \alpha}$ is mediated by a PKC-dependent ERK-MAP kinase pathway in bovine luteal cells. Endocrinology, 142:887-895, 2001.

82. Chen DB, Westfall SD, Fong D, Roberson MA, Davis JS. PGF $2 \alpha$ stimulates the Raf/MEK1/MAPK signaling cascade in bovine luteal cells. Endocrinology 139:3876-85, 1998.

83. Chen LY, Watanabe K, Hayaishi O. Purification and characterization of prostaglandin F synthase from bovine liver. Arch Biochem Biophys 296:17-26, 1992. 
84. Choudhary E, Costine BA, Wilson ME, Inskeep EK, Flores JA. Prostaglandin F2 alpha independent and dependent regulation of the bovine luteal endothelin system. Domes Anim Endocrin 27:63-79, 2004.

85. Choudhary E, Sen A, Inskeep EK, Flores JA. Developmental sensitivity of the bovine corpus luteum (CL) to prostaglandin F2 $\alpha$ (PGF2 $\alpha$ ) and endothelin-1: is ET-1 a mediator of the luteolytic actions of PGF2 $\alpha$ or a tonic inhibitor of progesterone secretion. Biol Reprod 72:633-642, 2005.

86. Christenson LK, Devoto L. Cholesterol transport and steroidogenesis by the CL. Reprod Biol and Endoc1:1-9, 2003.

87. Christenson LK, Johnson PF, McAllister JM, Strauss JF III. CCAAT/enhancerbinding proteins regulate expression of human StAR gene. Biol Chem 274:2659198, 1999.

88. Christenson LK, McAllister JM, Martin KO, Javitt NB, Osborne TF, Strauss JF. Oxysterol regulation of StAR protein gene expression. Structural specificity and transcriptional and posttranscriptional actions. J Biol Chem 273:30729-35, 1998.

89. Christenson LK, Stouffer RL. Isolation and culture of microvascular endothelial cells from the primate CL. Biol Reprod 55:1397-1404, 1996.

90. Clark BJ, Wells J, King SR, Stocco DM. The purification, cloning and expression of a novel LH-induced mitochondrial protein in MA-10 mouse leydig tumor cells: characterization of the StAR. J Biol Chem 269:28314-322, 1994.

91. Clark JD, Lin LL, Kriz RW, Ramesh CS, Sultzman LA, Lin AY, Milona N, Knopf JL. A novel arachidonic acid selective $\mathrm{CPLA}_{2}$ contains a calcium dependent translocation domain with homology to PKC and GAP. Cell 65:1043$1051,1991$.

92. Clark MA, Chen MJ, Crooke ST, Bomalaski JS. TNF (cachectin) induces PLA2activating protein in endothelial cells. Biochem J 250: 125-132, 1988.

93. Clarke CL. Cell-specific regulation of progesterone receptor in the female reproductive system. Mol Cell Endocrinol 70:C29-C33, 1990.

94. Clemens JW, Robker RL, Kraus WL, Katzenellenbogen BS, Richards JS. Hormone induction of progesterone receptor (PR) messenger ribonucleic acid and activation of PR promoter regions in ovarian granulosa cells: Evidence for a role 
of cyclic adenosine $3^{\prime}, 5^{\prime}$ monophosphate, but not estradiol. Mol Endocrinol $12: 1204-1214 ; 1998$.

95. Cluster EE, Lamsa JC, Eldering JA, McCracken JA. Identification of functional high and low affinity states of the prostaglandin F2 $\alpha$ receptor in the ovine corpus luteum in vivo and their role in hormone pulsatility. Endocrinology 3: 761-764, 1995.

96. Cohn SM, Schloemann S, Tessner T, Seibrt K, Stenson WF. Crypt stem cell survival in the mouse intestinal epithelium is regulated by prostaglandins synthesized through Cox-1. J Clin Inves 99:1367-1379, 1997.

97. Corner GW. De Graf Rmullierrum Organis Generationi Inservientius. Leyden, 1672, translated by GW Corner. In: Essays in Biology. Berkeley, CA: Univ. of California Press, 1943.

98. Corner GW, Allen WM. Normal growth and implantation of embryos after very early ablation of the ovaries, under the influence of the extracts of the corpus luteum. AmJ.Physiol 88:340-346, 1929.

99. Costine B. Mechansims of reduced luteal sensitivity to $\mathrm{PGF}_{2 \alpha}$ in ruminants. Dissertation submitted to Davis College of Agriculture, Forestry and Consumer Sciences at Wet Virginia University, 2004.

100. Crivello JF, Jefcoate CR. Mechanisms of corticotropin action in rat adrenal cells. I. The effects of inhibitors of protein synthesis and of microfilament formation on corticosterone synthesis. Biochem.Biophys.Acta 542:315-329, 1978.

101. Crooke ST, Mattern M, Sarau HM, Winkler JD, Balcarek J, Wong A, Bennett CF. The signal transduction system of the leukotriene D4 receptor. Trends Pharmacol Sci 10:103-107, 1989.

102. Davis JS, May JV, Keel BA. Mechanisms of hormone and GF action in the bovine CL. Theriogenology 45:1351-80, 1996.

103. Davis JS, Alila HW, West LA, Corradino RA, and Hansel W. Acute effects of prostaglandin F $2 \alpha$ on inositol phospholipid hydrolysis in the large and small cells of bovine corpus luteum. Mol Cell Endocrinology 58: 43-50, 1988. 
104. Davis JS, Weakland LL, Weiland DA, Fares RV, West LA. Prostaglandin F2 alpha stimulates phosphotidylinositol 4,5 biphosphate hydrolysis and mobilizes intracellular calcium in bovine luteal cells. PNAS 84:3728-32, 1987.

105. Derossi D, Joliot AH, Chassaing G, Prochiantz A. The third helix of the Antennapedia homeodomain translocates through biological membranes. J Biol Chem 269:10444-10450, 1994.

106. Dey SK, Hoversland RC, Johnson DC. PLA2 activity in the rat uterus: modulation by steroid hormones. J Steroid Horm 23:619-630, 1982.

107. Dharmarajan AM, Bruce NW, Meyer GT. Quantitative ultrastructure characteristics relating to transport between luteal cell cytoplasm and blood in the CL of the pregnant rat. Am.Janat 172:87-99, 1985.

108. Diaz FJ, Anderson LE, Wu YL, Rabot A, Tsai SJ, Wiltbank MC. Regulation of progesterone and prostaglandin F2alpha production in the CL. Mol Cell Endocrinol 191:65-80, 2002.

109. Diaz FJ, Crenshaw TD, Wiltbank MC. Prostaglandin F2 $\alpha$ induces distinct physiological responses in porcine CL after acquisition of luteolytic capacity. Biol Reprod 63:1504-1512, 2000.

110. Diekman MA, O'Pallaghan P, Nett TM, Niswender GD. Effect of PGF $2 \alpha$ on the number of LH receptors in ovine CL. Biol Reprod 19:1010-13, 1978.

111. Duffy DM, Stouffer RL. Gonadotropin versus steroid regulation of the corpus luteum of the rhesus monkey during simulated early pregnancy. Biol Reprod 57:1451-1460; 1997.

112. Eggleston DL, Wilken C, Van Kirk EA, Slaughter RG, Ji TH, Murdoch WJ. Progesterone induces expression of endometrial mRNA encoding for cyclogenase (sheep). Prostaglandins39:675-683, 1990.

113. Einspanier R, Miyamoto A Sauerwien H, Miyamoto A, Gunther J, Meyer HHD, Schams D. Binding and action of IGF and insulin in bovine luteal tissue during the oestrus cycle. J Reprod Fertil 96:103-115, 1999.

114. Evans JJ. Oxytocin and the control of LH. J Endocrinology.151:169-174, 1996. 
115. Ezashi T, Sakamoto K, Miwa K, Okuda EA, Ito S, Hayaishi O. Genomic organization and characterization of the gene encoding bovine $\mathrm{PGF}_{2 \alpha}$ receptor. Gene 190:271-278, 1996.

116. Fairchild DL, Pate JL. Modulation of bovine luteal cell synthesis capacity by interferon-gamma. Bio Reprod 44:357-363, 1991.

117. Farin CE, Nett TM, Niswender GD. Effects of LH on the luteal cell populations in hypophysectomized ewes. J Reprod Fertil 88:61-70, 1990.

118. Farin CE, Moeller CL, Sawyer HR, Gamboni F, Niswender GD. Morphometric analysis of cell types in the ovine CL throughout the estrous cycle. BiolReprod 35:1299-1308, 1986.

119. Fehr S, Ivell R, Koli R, Schamms D, Fields M, Richter D. Expression of oxytocin gene in the large cells of the bovine CL. FEBS Let 210:45-50, 1987.

120. Fenyves A, Saxer M, Spanel-Borowski K. Bovine microvascular endothelial cells of separated morphology differ in growth and response to the action of interferon gamma. Experientia 50:99-104, 1994.

121. Ferra N, Davis-Smith T. The biology of VEGF. Endoc Rev 18:4-25, 1997.

122. Fields MJ, Fields PA. Morphological characteristics of bovine CL during estrous cycle and pregnancy. Theriogenology 45:1295-1325, 1996.

123. Fields MJ, Fields PA. Luteal neurophysin in the nonpregnant cow and ewe: immunocytochemical localization in membrane-bound secretory granules of the large luteal cells. Endocrinology 118:1723-25, 1986.

124. Fields PA, Eldridge RK, Fuchs AR, Roberts RF, Fields MJ. Human placenta and bovine CL oxytocin. Endocrinology 112:1544-46, 1983.

125. Filion F, Bouchard N, Goff AK, Lussier JG, Sirois J. Molecular cloning and induction of bovine prostaglandin $\mathrm{E}$ synthase by gonadotropins in ovarian follicle prior to ovulation in vivo. J Biol Chem 276:34323-34330, 2001.

126. Fitz TA, Hoyer PB, Niswender GD. Interactions of prostaglandins with subpopulations of ovine luteal cells. I. Stimulatory effects of prostaglandins E1, E2 and I2. Prostaglandins 28:119-126, 1984a. 
127. Fitz TA, Mock EJ, Mayan MH, Niswender GD. Interactions of prostaglandins with subpopulations of ovine luteal cells.II. inhibitory effects of PGF2 $\alpha$ and protection by PGE2. Prostaglandins 28:127-138, 1984 b.

128. Fitz A, Mayan MH, Sawyer HR, Niswender GD. Characretization of two steroidogenic cell types in the ovine CL. Biol.Reprod 27:703-722, 1982.

129. Flint APF, Leat WMF, Sheldrick EL, Stewart HJ. Stimulation of phosphoinositide hydrolysis by oxytocin and the mechanism by which oxytocin controls prostaglandin synthesis in the ovine endometrium. Bioche J 237:797-805, 1986.

130. Flint APF, Sheldrick EL. Ovarian oxytocin is stimulated by prostaglandins. Nature 297:587-588, 1982.

131. Flores JA. Gene expression of ET-1 in the porcine ovary: follicular development. Biol Reprod 63:1377-82, 2000.

132. Flores JA, Garmey JC, Lahav M, Velduis JD. Mechanisms underlying endothelin's inhibition of FSH-stimulated progesterone production by ovarian granulose cells. Mol Cell Endo 156:169-178, 1999.

133. Flores JA, Aguirre C, Sharma OP, Veldhuis JD. LH stimulates both intracellular calcium ion mobilization and transmembrane cation influx in single ovarian (granulosa) cells: Requirement as a cellular mechanism of LH-calcium dose response. Endocrinology 139:3606-12, 1998.

134. Flores JA, Winters TA, Knight JW, Veldhuis JD. Nature of endothelin binding in the porcine ovary. Endocrinology 136:5014-19, 1995.

135. Flores JA, Quyyumi S, Leong DA, Veldhuis JD. Actions of ET-1 on swine ovarian (granulosa) cells and CL. Endocrinology 131:1350-57, 1992.

136. Flores JA, Veldhuis JD, Leong DA. Angiotensin II induces calcium release in a sub-population of single ovarian (granulosa) cells. Mol Cell Endocrinol 81:1-10, 1991.

137. Flores JA, Veldhuis JD, Leong DA. Follicle stimulating hormone evokes an increase in intracellular free calcium ion concentrations in single ovarian (granulosa) cells. Endocrinology 127:3172-3179, 1990. 
138. Fong GH, Rossant J, Gertsenstein M, Breitman ML. Role of Flt-1 receptor tyrosine kinase in regulating the assembly of vascular endothelium. Nature 376:66-70, 1995.

139. Ford SP, Weems CW, Pitts RE, Pexton JE, Butcher RL, Inskeep EK. Effects of estradiol-17 $\beta$ and progesterone on prostaglandin Fin sheep uteri and uterine venous plasma. J Anim Sci 41:1407-13, 1975.

140. Fraenel L. Experimentelle untersuchenge uber die function des corpus luteum (Theorie von Born). Allg.Med.Central-Ztg 70:1209, 1901.

141. Fraser HM, Abbott M, Laird NC, McNeilly AS, Nestor JJ, Vickery BH. Effects of LH-releasing hormone antagonist on the secretion of $\mathrm{LH}, \mathrm{FSH}$, prolactin and ovarian steroids at different stages on the luteal phase in the stumptailed macaque J Endocrinol 111:83-90, 1986.

142. Friden BE, Runesson E, Halhlin M, Brannstrom M. Evidence for nitric oxide acting as a luteolytic factor in the human corpus luteum. Mol Human Reprod 6:397-403, 2000.

143. Friedman A, Weiss S, Levy N, Meidan R. Role of TNF- $\alpha$ and its type 1 receptor in luteal regression: induction of programmed cell death in bovine CL derived endothelial cells. Biol Reprod 63:1905-12, 2000.

144. Garrett JE, Geisert RD, Zavy MT, Morgan GL. Effect of exogenous progesterone on cycle length, embryonic development and maintenance of pregnancy in the bovine. J Reprod Fertil 84:437-446, 1988.

145. Garverick HA, Smith MF, Elmore RG, Morehouse GL, Agudo SPL, Zahler WL. Changes and interrelationships among luteal LH receptors, adenylate cyclase activity and phosphodiesterase activity during bovine estrous cycle. $\mathrm{J}$ Anim Sci 61:216-223, 1985.

146. Gibson KH. Biosynthesis and metabolism of prostaglandins and thromboxanes. Pp 8-18. In "Prostaglandins and Thromboxanes" SM Roberts and RF Newton eds. Butterworth and Co (England), 1982.

147. Gijon MA, Leslie CC. Regulation of arachidonic acid release and $\mathrm{CPLA}_{2}$ activation. J Leuko Biol 65:330-336, 1999. 
148. Ginther OJ. Local versus systemic uteroovarian relationships in farm animals. Acta Vet Scand Suppl.77:103-15, 1981.

149. Girsh E, Milvae RA, Wang W, Meidan R. Effect of ET-1 on bovine luteal cell function: role of prostaglandin F2alpha induced antisteroidogenic action. Endocrinology 137:1306-11, 1996a.

150. Girsh E, Wang W, Mamluk R, Arditi F, Friedman A, Milvae RA, Meidan R. Regulation of ET-1 expression in the bovine CL:elevation by $\mathrm{PGF}_{2 \alpha}$. Endocrinology 137:5191-96, 1996b.

151. Girsh E, Greber Y, Meidan R. Luteotropic and luteolytic interactions between small and large luteal-like cells and endothelial cells. Biol Reprod 52:954-962, 1995.

152. Goede V, Schmidt T, Kimmmmina S, Kozian A, Augustin HG. Analysis of blood vessel maturation processes during cyclic ovarian angiogenesis. Lab Invest 78:1385-94, 1998.

153. Gospodarowicz D, Massoglia S, Cheng J, Fujii DK. Effect of FGF and lipoproteinson the proliferation of EC derived from the bovine adrenal cortex, brain cortex and CL capillaries. J.Cell.Physio 127:121-136, 1986.

154. Gospodaowicz D, Cheng J,Lui GM, Baird A, Esch F, Bohlen P. CL angiogenic factor is related to fibroblast growth factor. Endocrinology 117:2283$91,1985$.

155. Graf GA, Burns PD, Silvia WJ. Expression of a $\mathrm{cPLA}_{2}$ by ovine endometrium on days 11-14 of a stimulated oestrous cycle. J Reprod Fertil 115:357-363, 1999.

156. Graness A, Adomeit A, Ludwig B, Muller WD, Kaufmann R, Liebmann C. Novel bardykinin signaling events in PC-12: stimulation of cAMP pathway leads to cAMP-mediated translocation of PKC $\varepsilon$. Niochem J 1997; 327:147-154.

157. Graves PE, Pierce KL, Bailey TJ, Rueda BR, Gil W, Woodward DF, Yool AJ, Hoyer PB, Regan JW. Cloning of a receptor for $\mathrm{PGF}_{2 \alpha}$ from the ovine CL. Endocrinology 136:3430-36, 1995. 
158. Gray MO, Karliner JS, Mochly-Rosen D. A selective $\varepsilon$-PKC antagonist inhibits protection of cardiac myocytes from hypoxia-induced cell death. J Biol Chem 272:30945-30951, 1997.

159. Grazul-Bilska AT, Redmer DA, Jablonka-Shariff A, Biondini ME, Reynolds LP. Proliferation and P4 production of ovine luteal cells from several stages of the estrous cycle: effects of FGF and LH. Canadian Journal of Physiology and Pharmacology 73:491-500, 1995.

160. Grazul-Bilska AT, Redmer DA, Killilea SD, Kraft KC, Reynolds LP. Production of mitogenic factor(s) by ovine CL throughout the estrous cycle. Endocrinology 130: 3625-32, 1992.

161. Grazzini E, Guillon G, Mouillac B, Zingg HH. Inhibition of oxytocin receptor function by direct binding of progesterone. Nature 392:509-512, 1998.

162. Griffeth RJ, Nett TM, Burns PD, Escudero M, Inskeep EK, Niswender GD. Is luteal production of PGF2 $\alpha$ required for luteolysis? Biol Reprod 66:465, 2002.

163. Gronroos E, Andersson T, Schippert A, Zheng L, Sjolander A. Leukotriene D4-induced mobilization of intracellular Ca2+ in epithelial cells is critically dependent on activation of the small GTP-binding protein Rho. Biochem J 316:239-245, 1996.

164. Grummer RR, Carrol DJ. A review of lipoprotein cholesterol metabolism: importance to ovarian function. J.Anim.SCI 66:3160-73, 1988.

165. Grusenmeyer DP, Pate JL.Localization of prostaglandin F2alpha inhibition of lipoprotein use by bovine luteal cells. J Reprod Fertil 94:311-318, 1992.

166. Gwynne JT, Strauss JFd. The role of lipoproteins in steroidogenesis and cholesterol metabolism in steroidogenic glands. Endocr Rev 3:299-329, 1982.

167. Ham EA, Cirilo VJ, Zanetti ME, Keul FA. Estrogen-directed synthesis of specific prostaglandins in uterus. PNAS 72: 1420-1424, 1975.

168. Hammer GD, Krylova I, Zhang Y, Darimont BD, Simpson K, Weigel NL, Ingraham HA. Phosphorylation of nuclear receptor SF-1 modulates coactivator 
recruitment: integration of hormone signaling in reproduction and stress. Mol Cell 3:521-526, 1999.

169. Hansel W, Alila HW, Dowd JP, Milvae RA. Differential origin and control mechanisms in small and large bovine luteal cells. J Reprod Fertil 43(Suppl): 77-89, 1991.

170. Hansel W, Alila HW, Dowd JP, Yang XZ. Control of steroidogenesis in small and large bovine luteal cells.Aust J Biol Sci 40:331-347, 1987.

171. Hansen HS. Purification and assay of 15-ketoprostaglandin delta 13rductase from bovine lung. Methods Enzymol 86:156-162, 1982.

172. Hartmen H, Wettstein A. Ein krystallisiertes hormon aus corpus luteum. Helv.Chim.Acta 17:878:882, 1934.

173. Hasumoto K, Sugimoto Y, Gotoh M, Segi E, Yamasaki A, Yamaguchi M, Honda H, Hirai H, Negishi M, Kakizuka A, Ichikawa A. Characterization of the mouse $\mathrm{PGF}_{2 \alpha}$ receptor gene: a transgenic mouse study of a regulatory region that controls its expression in the stomach and kidney but not in the ovary. Genes Cells 2:571-580, 1997.

174. Hauet T, Liu J, Li H, Gazouli M, Culty M, Papadooulos V. PBR, StAR and PKA: partners in cholesterol transport in steroidogenic cells. Endoc Res 28:395-401, 2002.

175. Hayashi K, Miyamoto A, Berisha B, Kosmann MR, Okuda K, Schams D. Regulation of angiotensin II production and angiotensin receptors in microvascular endothelial cells from bovine CL. Biol Reprod 62:162-167, 2000.

176. Hehnke KE, Clark CL, Taylor MJ, Ford SP. Presence and localization of TNF- $\alpha$ in the CL of nonpregnant and pregnant pigs. Biol Reprod 53:1339-44, 1995.

177. Hehnke KE, Christenson LK, Ford SP, Taylor M. Macrophage infiltration into the porcine $\mathrm{CL}$ during $\mathrm{PGF}_{2 \alpha^{-}}$induced luteolysis. Biol Reprod 50:10-15, 1994.

178. Henderson KM, Scaramuzzi RJ, Baird DT. Simultaneous infusion of PGE2 antagonizes the luteolytic action of PGF2 $\alpha$ in vivo. J endocrinol 72:379-83, 1977. 
179. Hild-Petito S, Stouffer RL, Brnner RM. Immunocytochemical localization of estradiol and progesterone receptors in the monkey ovary throughout the menstrual cycle. Endocrinology 123:2896-2905, 1988.

180. Hinckley ST, Milvae RA. Endothelin-1 mediates prostaglandin F2 $\alpha$ induced luteal regression in the ewe. Biol Reprod 64:1619-1623, 2001.

181. Hirabayashi T, Murayama T, Shimizu T. Regulatory Mechanism and Physiological role of cPLA 2 .Biol Pharm Bull 27:1168-1173, 2004.

182. Hoyer PB. Regulation of luteal regression: the ewe as a model. J Soc Gyn Inves 5:48-57, 1998.

183. Hoyer PB, Kong W. Protein kinase A and C activities and endogenous substrates in ovine small and large luteal cells. Mol Cell Endocrinol 62:203-215, 1989.

184. Hrabovszky E, Kall I, Hajszn T, Shughrue PJ, Merchenthaler I, Lipssits Z. Expression of estrogen receptor-mRNA in oxytocin and vasopressin neurons of the rat supraoptic and paraventricular nuclei. Endocrinology 139:2600-260, 1998.

185. Ikonen E. Molecular mechanisms of intracellular cholesterol transport. Curr.Opin.Lipidol 8:60-64, 1997.

186. Inskeep EK. Preovulatory, postovulatory and postmaternal recognition effects of concentrations of progesterone on embryonic survival in the cow. $J$ Anim Sci 82:E24-E39, 2004.

187. Inskeep EK. Potential uses of prostaglandins in control of reproductive cycles of domestic animals. J Anim Sci 36:1149-57, 1973.

188. Ito $\mathrm{M}$, $\mathrm{Yu} \mathrm{RN}$, Jmeson JL. SF-1 contains a carboxy-terminal transcriptional activation domain that interacts with steroid receptor coactivator 1. Mol Endocrinol 12:290-301, 1998.

189. Ivell R, Hunt N, Abend N, Brackman B, Nollemeyer D, Lamsa JC McCracken JA. Structure and ovarian expression of oxytocin gene in sheep. Reprod Fertil Dev 2:703-711, 1990.

190. Ivell R, Brackett KH, Fields MJ, Richter D. Ovulation triggers oxytocin gene expression in the bovine ovary. FEBS Lett 190: 263-267, 1985. 
191. Ivell R, Richter D. The gene for the hypothalamic peptide hormone oxytocin is highly expressed in the bovine CL: biosynthesis, structure and sequence analysis. EMBO J 3:2351-54, 1984.

192. Iwai M, Hori S, Shigemoto R, Kanzaki H, Mori T, Nakanishi S. Localization of endothelin receptor mRNA in the rat ovary and fallopian tube by in situ hybridization. Biol Reprod 49:675-80, 1993.

193. Jablonka-Shariff A, Grazul-Bilska AT, Redmer DA, Reynolds LP. Cellular proliferation and FGF in the CL during early pregnancy in ewes. Growth Factors 14:15-23, 1997.

194. Jablonka-Shariff A, Grazul-Bilska AT, Redmer DA, Reynolds LP. Growth and cellular proliferation of ovine CL throughout the estrous cycle. Endocrinology 133:1871-79, 1993.

195. Jakobsson PJ, Thoren S, Morgenstern R, Samuelsson B. Identification of prostaglandin E synthase: A microsomal, glutathione-dependent, inducible enzyme, constituting a potential novel drug target. PNAS 96:7220-7225, 1999.

196. Jaroszewski JJ, Skarzynski DJ, Hansel W. NO as a local mediator of $\mathrm{PGF}_{2 \alpha}$-induced regression in bovine $\mathrm{CL}$ : an in vivo study. Exp Biol Med 228:741-748, 2003.

197. Jaroszewski JJ, Hansel W. Intraluteal administration of a NO synthase blocker stimulates P4 and OT secretion and prolongs the life span of the bovine CL. Proc Soc Exp Biol Med 224: 50-55, 2000.

198. Jefcoate CR, McNamara BC, Artemenko I, Yamazaki T. Regulation of cholesterol movement to mitochondrial cytochrome P450sce in steroid hormone synthesis J Sted Biochem Mol Biol 43:751-767, 1992.

199. Jez JM, Flynn TG, Penning TM. A new nomenclature for the aldo-keto reductase superfamily. Biochem Pharmacol 54:639-47, 1997.

200. Johnson JA, Gray MO, Chen CH, Mochly-Rosen D. A protein kinase C translocation inhibitor as an isozyme-selective antagonist of cardiac function. $\mathrm{J}$ Biol Chem 271:24962-24966, 1996.

201. Johnson WJ, Phillips MC, Rothblat GH. Lipoproteins and cellular cholesterole homeostasis. Subcell.Biochem 28:235-276, 1997. 
202. Jones LS, Ottobre JS, Pate JL. P4 regulation of LH receptors on cultured bovine luteal cells. Mol Cell Endocrinol 85:33-39, 1992.

203. Juengel JL, Haworth JD, Rollyson MK, Silva PJ, McIntush EW, Sawyer HR, Niswender GD. Effect of dose of PGF2 $\alpha$ on steroidogenic components and oliginucleosomes in ovine luteal tissue. Biol Reprod 62:1047-51, 2000.

204. Juengel JL, Niswender GD. Molecular regulation of luteal P4 synthesis in domestic ruminants. J Reprod Fertil Suppl 54:193-205, 1999.

205. Juengel JL, MebergBM, McIntush EW, Smith MF, Niswender GD. Concentration of mRNA encoding $3 \beta$-HSD and $3 \beta$-HSD enzyme activity following treatment of ewes with protaglandin F2alpha. Endocrine 8:45-50, 1998a.

206. Juengel JL, Melner MH, Clapper JA, Turzillo AM, Moss GE, Nett TM, Niswender GD. Steady-state concentrations of mRNA encoding two inhibitors of protein kinase C in ovine luteal tissue.J Reprod Fertil 113:299-305, 1998b.

207. Juengel JL, Nett TM, Anthony RV, Niswender GD. Effects of luteotropic and luteolytic hormones on the expression of mRNA encoding insulin-like growth-I and growth hormone receptor in the ovine CL. J.Reprod.Fertil 110:291$298,1997$.

208. Juengel JL, Wiltbank MC, Meberg BM, Niswender GD. Regulation of steady state concentrations of mRNA encoding $\mathrm{PGF}_{2 \alpha}$ receptor in ovine CL. Biol Reprod 54:1096-1102, 1996.

209. Juengel JL, Meberg BM, Turzillo AM, Nett T, Niswender GD. Hormonal regulation of mRNA encoding StAR in ovine CL. Endocrinology 136:542329,1995a.

210. Juengel JL, Nett TM, Tandeki TM, Eckery DC, Sawyer HR, Niswender GD. Effects of LH and GH on luteal development in hypophysectomized ewes. Endocrine 3:323-326, $1995 \mathrm{~b}$.

211. Jun SS, Chen Z, Pace MC, Shaul PW. Glicocorticoids downregulates cyclooxygenase-1 gene expression and prostacyclin synthesis in fetal pulmonary artery endothelium. Cir Res 84:193-200, 1999. 
212. Kanai N, Lu R, Satriano JA, Bao Y, Wolkoff AW, Schuster VL. Identification and characterization of a prostaglandin transporter. Science 268(5212):866-9, 1995.

213. Karam H, Valenaire O, Belair MF, Prigent-Sassy C, Rakotosalama A, Clozel M, Itskovitsz J, Bruenval P. The endothelin system in human and monkey ovaries: in situ gene expression of the different components. Cell Tissue Res 295:101-109, 1999.

214. Kedzierski RM, Yanagisawa M. Endothelin system: the double-edged sword in health and disease. Annu Rev Pharmacol Toxicol 41: 851-76, 2001.

215. Keranen LM, Dutil EM, Newton AC. PKC is regulated in vivo by three functionally distinct phosphorylation. Curr Biol 5:1394-1403, 1995.

216. Khachigian LM, Lindner V, Williams AJ, Colins T. Egr-1 induced endothelial gene expression: a common theme in vascular injury. Science 271:1427-31, 1996.

217. Kieborz-Loos KR, Garverick HA, Keisler DH, Hamilton SA, Salfen E, Younquist RS, Smith MF. Oxytocin induced secretion of prostaglandin F2 $\alpha$ in postpartum beef cow: effects of progesterone and estradiol-17 $\beta$ treatment. J Anim Sci81:1830-36, 1981.

218. Kim KJ, Li B, Winer J, Aemanini M, Gillet N, Phillips HS, Ferrarra N. Inhibition of VEGF induced angiogenesis suppresses tumor growth in vivo. Nature 362:841-844, 1993.

219. Kim L, Weems YS, Bridges PJ, LeaMaster BR, Ching L,Vincent DL, Weems CW. Effects of indomethacin, LH, PGE2, trilostane, mifepristone, ethamoxytriphetol (MER-25) on secretion of PGE, PGF2 $\alpha$ and P4 by ovine CL of pregnancy or the estrous cycle. Prostaglandins Other Lipid Mediat 63:189-203, 2001.

220. Kisanuki YYHR, Miyazaki J, Williams SC, Richardson JA, Yanagisawa M. Tie2-Cre transgenic mice: a new model for ET cell lineage analysis in vivo. Dev Biol 230:230-242, 2001.

221. Kobayashi S, Acosta TJ, Ozawa T, Hayashi K, Berisha B, Ohtani M, Schams, Miyamoto A. Intraluteal release of angiotensin II and progesterone in 
vivo during $\mathrm{CL}$ development in the cow: effect of vasoactive peptides. Biol Reprod 66:174-179, 2002.

222. Kobayashi S, Miyamoto A, Berisha B, Schams D. GH, but not LH, acts with luteal peptides on prostaglandin F $2 \alpha$ and P4 secretion by bovine CL in vitro. Prostaglandins Lipid Mediat 63:79-92, 2001a.

223. Kobyashi S, Berisha M, Amselgruber WM, Schams D, Miyamoto A.

Production and localization of angiotensin II in the bovine early CL: a possible interaction with luteal angiogenic factors and prostaglandin 2 alpha. J Endocrinol 170:369-80, 2001b.

224. Koos RD, Hansel W. The large and small cells of the bovine CL: ultra structure and functional differences. In: Dynamics of Ovarian Function, edited by N.B. Schwartz and M. Hunzicker-Dunn. New York: Rave, 197-203, 1981.

225. Koponen S, Kurkinen K, Akerman KE, Mochly-Rosen D, Chan PH, Koistinaho J. Prevention of NMDA-induced death of cortical neurons by inhibition of protein kinase Czeta. J Neurochem 86:442-450, 2003.

226. Kotwica J, Skarzynski D, Mlynarczuk J, Rekawiecki R. Role of PGE2 in basal and noradrenline induced P4 secretion by the bovine CL. Prostaglandins Other Lipid Mediat70:351-59, 2003.

227. Kotwica J, Skarzynski D. Influence of oxytocin removal from the CL on secretory function and duration of the oestrous cycle in cattle. J Reprod Fertil 97:411-417, 1993.

228. Koziorowski M, Stefanczyk-Krzymowska S, Czarnocki J, Krzymowski T. Counter current transfer and back transport of 3H-PGF2 alpha in the cow's broad ligament vasculature ipsilateral and contralateral to the corpus luteum. Acta Physiol Pol 40(1):96-103, 1989.

229. Kraft AS, Anderson WB. Phorbol esters increase the amount of calcium, phospholipid-dependent protein kinase associated with plasma membrane. Nature 301:621-623, 1983.

230. Krueger RJ, Orme-Johnson NR. Acute adrenocorticotropic hormone stimulation of adrenal corticosteroidogenesis. J Biol Chem 258:10159-67, 1983. 
231. Kruip TA, Vullings HG, Schams D, Jonis J, Klarenbeek A. Immunocytochemical demonstration of oxytocin in bovine ovarian tissues. Acta Endocrinol (Copenh) 109:537-542, 1985.

232. Kubata BK, Duszenko M, Kabututu Z, Rawer M, Szallies A, Fujimori K, Inui T, Nozaki T, Yamashita K, Horii T, Urade Y, Hayaishi O.Identification of a novel prostaglandin f (2alpha) synthase in Trypanosoma brucei. J Exp Med 192:1327-38, 2000.

233. Kuchinke W, Barski O, Watanabe K, Hayaishi O.A lung type prostaglandin $\mathrm{F}$ synthase is expressed in bovine liver: cDNA sequence and expression in E. coli. Biochem Biophys Res Commun183:1238-46, 1992.

234. Lee SC, Levine L. Prostaglandin metabolism II. Identification of two 15hydroxyprostaglandin dehydrogenase types. J Biol Chem 250:548-552, 1975.

235. Lee YH, Kim I, Laporte R, Walsh MP, Morgan KG. Isozyme-specific inhibitors of protein kinase $\mathrm{C}$ translocation: effects on contractility of single permeabilized vascular muscle cells of the ferret. J Physiol 517:709-720, 1999.

236. Lehel C, Olah Z, Mischak H, Mushinski JF, Anderson WB. Over expression of PKC- $\delta$ and $-\varepsilon$ subtypes in NIH 3 T3 cells exhibit differential subcellular localization and differential regulation of sodium-dependent phosphate uptake. JBC 269:4761-66, 1994.

237. Lehmann I, Brylla E, Sittig D, Spanel-Borowski K, Aust G. Microvascular endothelial cells differ in their basal and TNF-alpha-regulated gene expression of adhesion molecules and cytokines. J Vas Res 37:408-416, 2000.

238. Lehman MN, Ebling FJP, Moenter SM, Karsch FJ. Distribution of estrogen receptor-immunoreactive cells in the sheep brain. Endocrinology 133:876-886, 1993.

239. Lehninger AL. Principles of Biochemistry (Worth, NY). Pp 389-566, 2000.

240. Levy N, Gordin M, Mamluk R, Yanagisawa M, Smith M, Hampton J. Distinct cellular localization and regulation of ET-1 and ECE-1 expression in the bovine CL: implications for luteolysis. Endocrinology 142: 254-60, 2001. 
241. Levy N, Kobayashi S, Roth Z, Wolfenson D, Miyamoto A, Meidan R. Administration of $\mathrm{PGF}_{2 \alpha}$ during the early bovine luteal phase does not alter the excpression of ET-1 and of its type A receptor: a possible cause for CL refractoriness. Biol Reprod 63: 377-382, 2000.

242. Lewis PE, Warren JE. Effect of indomethacin on luteal function in ewes and heifers. J Anim Sci 45:763-767, 1977.

243. Lewis PE, Taylor WC, Inskeep EK. Exogenous progesterone on ovine CL. J Anim Sci 27:1193 (abstract), 1968.

244. Lhmann I, Brylla E, Sittig D, Spanel-Borowski K, Aust G. Microvascular endothelial cells differ in their basal and TNF alpha regulated gene expression of adhesion molecules and cytokines. J Vas Res 37:408-416, 2000.

245. Li H, Papadopoulos V. PBR function in cholesterol transport. Identification of a putative cholesterol recognition/interaction amino acid sequence and consensus pattern. Endocrinology 139:4991097, 1998.

246. Liebermann J, Schams D. Action of somatotrophin on oxytocin and P4 release from microdialysed bovine CL in vitro. J Endocrinol 143:243-250, 1994.

247. Lin D, Sugawar T, Strauss JF, Clark BJ, Stocco DM, Saenger P, Rogol A, Miller WL. Role of StAR protein in adrenal and gonadal steroidogenesis. Science 267:1828-31, 1995.

248. Lin LL, Lin L, Watermann M, Lin AY, Knopf JL, Seth A, Davis RJ. cPLA $_{2}$ is phosphorylated and activated by MAO kinase. Cell 72:269-278, 1993.

249. Lincoln DW. The posterior pituitary, In: Reproduction in mammals. Book 3: Hormonal control of reproduction ( $2^{\text {nd }}$ ed.) edited by Austen CR and Short RV. Vambridge, UK: Cambridge Uni Press, p21-51, 1984.

250. Lioutas CH, Einspanier A, Kascheike B, Walther N, Ivell R. An autocrine progesterone positive feedback loop mediates oxytocin upregulation in bovine granulosa cells during luteinization. Endocrinology 138:5059-5062; 1997.

251. Liu B, Nakashima S, Ito S, Nozawa Y. PLD activation in Chinese Hamster Ovary $(\mathrm{CHO})$ cells transfected with PGF $2 \alpha$ receptor cDNA. Prostaglandins 51: 233-248, 1996. 
252. Lu R, Kanai N, Bao Y, Schuster VL. Cloning, in vitro expression, and tissue distribution of a human prostaglandin transporter cDNA (hPGT). J Clin Invest 98(5):1142-9, 1996.

253. Luck MR, Munker M. beta-adrenoreceptors mediate the catecholamineinduced stimulation of OT secretion from cultured bovine granulose cells. Reprod Fertil Dev 3:715-23, 1991.

254. Lucy MC, Byatt JC, Curran TL, Curran DF, Collier RJ. Placental lactogen and somatotropin: hormone binding to the CL and effects on the growth and functions of the ovary in heifers. Biol Reprod 50: 1136-1144, 1994.

255. Lucy MC, Collier RJ, Kitchell ML, Dibner JJ, Hauser SP, Kriui GG. Immunohistochemical and nucleic acid analysis of somatotropin receptor populations in the bovine ovary. Biol Reprod 48: 1219-27, 1993.

256. Luscher TF, Barton M. Endothelins and endothelin receptor antagonists therapeutic considerations for a novel class of cardiovascular drugs. Circulation 102:2434, 2000.

257. Lysz TW, Zweig A, Keeting PE. Examination of mouse and rat tissue for evidence of dual forms of the fatty acid cyclooxegenase. Biochem Pharm 37:921$927,1988$.

258. Madore E, Harvey N, Parent J, Chapdelaine P, Arosh JA, Fortier MA. An aldose reductase with $20 \alpha$ - hydroxysteroid dehydrogenase activity is most likely the enzyme responsible for the production of PGF2 $\alpha$ in the bovine endometrium. J Biol Chem 278:11205-12, 2003.

259. Maeno-Hikichi Y, Chang S, Matsumura K, Lai M, Lin H, Nakagawa N, Kuroda S, Zhang JF. A PKC epsilon-ENH-channel complex specifically modulates N-type calcium channels. Nat Neurosci 6:468-475, 2003.

260. Maggi M, Barni T, Orlando C, Fantoni G, Finetti G, Vannelli GB, Mancina R, Gloria L, Bonaccorsi L, Yanagisawa M. ET-1 and its receptors in human testis. J Androl 16:213-24, 1995.

261. Magnes RR, Huie JM, Hoyer GL, Huecksteadt TP, Reynolds LP, Seperich GJ, Whysong G, Weems Cw. Effect of chronic and ipsilateral or contralateral 
intrauterine infusion of PFE2 on luteal function of unilaterally ovariectomized ewes. Prostaglandins Med 6:389-401, 1981.

262. Magnus V. Ovariets betydning for svangerskabet med soerligt hensyn til corpus luteum. Norsk.Mag.Loegevidensk 62:1138, 1901.

263. Malphighi M. De Structura Glandarum Conglobatarum. London:Apud Richardum Chiswell, 1689.

264. Mamluk R, Greber Y, and Meidan R. Hormonal regulation of the messenger ribonucleic acid expression of steroidogenic factor-1, steroidogenic acute regulatory protein and cytochrome P450 side-chain cleavage in bovine luteal cells. Biol Reprod 60: 628-634, 1999.

265. Mamluk R, Chen D, Greber Y, Davis JS, Meidan R. Characterization of mRNA expression for $\mathrm{PGF}_{2 \alpha}$ and $\mathrm{LH}$ receptors in various bovine luteal cells. Biol Reprod 58:849-856, 1998.

266. Manna PR, Dyson MT, Eubank DW, Clark Bj, Lalli E, Sassone-Corsi P, Zeleznik AJ, Stocco DM. Regulation of steroidogenesis and the StAR by a member of the cAMP response-element binding protein family. Mol Endocrinol 16:184-199, 2002.

267. Martinez-Zaguilan R, Wegner JA, Gillies RJ, Hoyer PB. Differential regulation of calcium homeostasis in ovine large and small luteal cells. Endocrinol 135: 2099-2108, 1994.

268. Mathieu MN, Hamroun D, Pouzeratte Y, Guerineau NC, Guillon G, Chevillard C. Adrenal steroid-secreting cells express ET-1. Endocr Res 24:743-7, 1998.

269. Mayerhofer A, Spanel-Borowski K, Spanel-Borowski K. Cultured microvascular endothelial cells derived from bovine CL possess NCAM-140. Exp Cell Res 201:545-588, 1992.

270. McCracken JA, Custer EE, Lamsa JC. Luteolysis: A neuroendocrine mediated event. Physiol Review 79:263-323, 1999.

271. McCracken JA, Custer EE, Lamsa JC, Robinson AG. The central oxytocin pulse generator, a pacemaker of luteolysis. Adv Exp Md Biol 395:133-154, 1995. 
272. McCracken JA. Hormone receptor control of PGF2 $\alpha$ secretion by the ovine uterus. Adv Prostaglandin Thromboxane Res 8: 1329-44, 1980.

273. McCracken JA. Prostaglandins and luteal regression: a review. Res Prostaglandins 1:1-4, 1972.

274. McGuire WJ, Juengel JL, Niswender GD. Protein kinase C second messenger system mediates the antisteroidogenic effects of prostaglandin F2 alpha in the ovine corpus luteum in vivo. Biol Reprod 1994 51:800-806.

275. McLean AS, Billheimer JT, Warden KJ, Irby RB. Prostaglandin F2alpha mediates ovarian sterol carrier protein-2 expression during luteolysis. Endocrnol 136:4963-71, 1995.

276. McNeilly AS, Crow WJ, Fraser HM. Suppression of pulsatile LH secretion by GnRH-antagonist does not affect episodic P4 secretion or CL function in ewes. J Reprod Fertil 96:865-874, 1992.

277. Median R, Levy N. ET-1 receptors and biosynthesis in the CL: molecular and physiological implications. Domest Anim Endocrinol 23: 287-98, 2002.

278. Meidan R, Milvae RA, Weiss S, Levy N, Friedman A. Intraovarian regulation of luteolysis. J Reprod Fertil Supp 54:217-228, 1999.

279. Median R, Aberdam E, Aflalo L. Steroidogenic enzyme content and P4 induction by cAMP generating agents and prostaglandin F2 in bovine theca and granulose cells luteinized in vitro. Biol Reprod 46:786-792, 1992.

280. Mellor H, Parker PJ. The extended PKC superfamily. Biochem 332:281292, 1998.

281. Meyer HH, Mittermeier T, Schams D. Dynamics of oxytocin, estrogen and progestin receptors in the bovine endometrium during the estrous cycle. Acta Endocrinol (Copenh) 118:96-104, 1988.

282. Miele L, Cordella-Miele E, Mukherjee AB. The uteroglobin gene, structure, molecular biology and new perspective on its function as a phospholipase A2 inhibitor. Endocr Rev 8:474-490, 1987.

283. Miller WL, Strauss JF. Molecular pathology and mechanism of action of the StAR protein. J Steroi Biochem Mol Biol 69:131-141, 1999. 
284. Milligrom E, Thi L, Atger, Baulieu EE. Mechanisms regulating the concentration and conformation of progesterone receptors in the uterus. J Biol Chem 248:6366-74, 1973.

285. Milvae RA. Inter-relationships between endothelin and prostaglandin $\mathrm{PGF}_{2 \alpha}$ in the corpus luteum function. Rev Reprod 5: 1-5, 2000.

286. Milvae RA, Hansel W. Inhibition of bovine luteal function by indomethacin. J Anim Sci 60:58-531, 1985.

287. Milvae RA, Hansel W. Prostacyclin, prostaglandin F2 $\alpha$ and P4 production by bovine luteal cells during estrous cycle. Biol Reprod 29:1063-68, 1983.

288. Milvae RA, Hansel W. The effects of PGI2 and 6-keto-PGI $1 \alpha$ on bovine plasma P4 and LH concentrations. Prostaglandins 20:641-647, 1980.

289. Mischak H, Goodnight JA, Kolch W, Martiny-Baron G, Schaechtle C, Kazanietz MG, Blumberg PM, Pierce JH, Mushinski JF. Overexpression of protein kinase C-delta and -epsilon in NIN 3T3cells induces opposite effects on growth, morphology, anchorage dependence and tumorigenicity. J Biol Chem 268:6090-6096, 1993.

290. Miyamoto Y, Sakumoto R, Sakabe Y, Miyake M, Okano A, Okuda K. TNF- $\alpha$ receptors are present in the CL throughout the oestrous cycle and during the early gestation period in pigs. Reprod Dom Anim 37:105-110, 2002.

291. Miyamoto Y, Skatzynski DJ, Okuda K. Is TNF $\alpha$ a trigger for the initiation of endometrial prostaglandin F2 $\alpha$ release at luteolysis in cattle? Biol Reprod 62:1109-15, 2000.

292. Miyamoto A, von Lutzow H, Schams D. Acute actions of PGF2 $\alpha$, E2 and I2 in microdialyzed bovine CL in vitro Biol Reprod 49:423-430, 1993.

293. Miyamoto A, Schams D. Oxytocin stimulates P4 release from microdialyzed bovine CL in vitro. Biol Reprod 44:1163-68, 1991.

294. Mochly-Rosen D, Gordon AS. Anchoring proteins for PKC: a means for isozyme selectivity.FASEB 12:35-42, 1998.

295. Mochly-Rosen D. Localization of PKC by anchoring proteins: a theme in signal transduction. Science 268:247, 1995. 
296. Mochly-Rosen D, Khaner H, Lopez J. Identification of intracellular receptor proteins for activated protein kinase C. Proc Natl Acad Sci U S A 88:3997-4000, 1991.

297. Moguilewsky M, Renaud JP. The relevance of hypothalamic and hypopyseal progestin receptors regulation in the induction and inhibition of sexual behavior in the female rat. Endocrinology 105:516-522, 1979.

298. Morgan GL, Geisert RD, McCann JP, Bazer FW, Ott TL, Mirando MA, Stewart M. Failure of luteolysis and extension of the interoestrous interval in sheep treated with progesterone antagonist mifepristone (RU 486). J Reprod Fertil 98:451-457, 1993.

299. Morita I, Schindler M, Regier MK, Otto JC, Hori T, DeWitt DL, Smith WL. Different intracellular locations for prostaglandin endoperoxide H synhase-1 and -2. J Biol Chem 270:10902-08, 1995.

300. MT Rae, GS Menzies, AS McNeilly, K Woad, R Webb, and TA Bramley. Specific non-genomic, membrane-localized binding sites for progesterone in the bovine corpus luteum. Biol Reprod 58: 1394 - 1406, 1998.

301. Mubarack M. Muthalif, Ying Hefner, Stéphane Canaan, Jason Harper, Huilin Zhou, Jean-Hugues Parmentier, Ruedi Aebersold, Michael H. Gelb, and Kafait U. Malik. Functional Interaction of Calcium-/Calmodulin-dependent Protein Kinase II and Cytosolic Phospholipase A2. J Biol Chem 276: 3965339660, 2001.

302. Muller L, Barret A, Etienne E, Median R, Valdenaire O, Corvol P, Tougard C. Heterodimerization of ECE-1 isoforms regulates the subcellular distribution of this metalloproteases. JBC 278:545-555, 2003.

303. Murakami M, Nakashima K, Kamei D, Masuda S, Ishikawa Y, Ishii T, Ohmiya Y, Watanabe K, Kudo I. Cellular prostaglandin E2 production by membrane bound prostaglandin E synthase-2 via Cox-1 and -2 . J Biol Chem 278:37937-47, 2003.

304. Murakami M, Naraba H, Tanioka T, Semmyo N, Nakatani Y, Kojima F, Ikeda T, Fueki M, Ueno A, Oh S, Kudo I. Regulation of prostaglandin E2 
biosynthesis by inducible membrane associated prostaglandin E2 synthase that acts in concert with Cox-2. J Biol Chem 275:32783-92, 2000.

305. Murakami M, Shimbara S, Kambe T, Kuwata H, Winstead M, Tischfield

J, Kudo I. The functions of five distinct mammalian phospholipase A2s in regulating arachidonic acid release. J Biol Chem 273:14411-23, 1998.

306. Murdoch WJ. Microtubular dynamics in granulose cells of periovulatory follicles and granulose cell derived (large) lutein cells of sheep: relationships to the steroidogenic folliculoluteal shift and functional luteolysis. Biol Reprod 54:1135-40, 1996.

307. Narymiya S, Sugimoto Y, Ushikubi F. Prostanoid receptors: Structure, properties and function. Physiological Reviews 79:1193-1222, 1999.

308. Natraj U, Richards JS. Hormonal regulation, localization and functional activity of progesterone receptor in granulosa cells of rat preovulatory follicles. Endocrinology 133:761-769; 1993.

309. Neufeld G, Ferrara N, Schweigerer L, Mitchell R, Gospodarowicz D. Bovine granulosa cells produce basic fibroblast growth factor. Endocrinology 121:597-603, 1987.

310. Newton AC. Regulation of PKC. Curr Opin Cell Biol 9:161-16, 1997.

311. Newton AC. Protein kinase C. Structure, function and regulation. J Biol Chem 270:28495-28498, 1995.

312. Nishimura R, Shaibaya M, Skarzynski DJ, Okuda K. Progesterone stimulation by LH involves the PLC pathway in bovine luteal cells. J Reprod Dev 50:257-261, 2004.

313. Niswender GD. Molecular control of luteal secretion of P4. Reproduction 123:333-339, 2002.

314. Niswender GD, Juengel JL, Silva PJ, Rollyson MK, Mcintush EW. Mechansims controlling the function and life span of the CL. Physiological Reviews 80:1-29, 2000.

315. Niswender GD, Nett TM. Corpus luteum and its control in infraprimate species. In: The Physiology of Reproduction, edited by E. Knobil and JD Neil. New York: Raven, vol1, 781-816,1994. 
316. Nothnick WB, Pate JL. Interleukin-1 $\beta$ is a potent stimulator of prostaglandin synthesis in bovine luteal cells. Biol Reprod 43:898-903, 1990.

317. O'Shea JD, Rodgers RJ, D’Occhio MJ. Cellular composition of cyclic corpus luteum of the cow. J Reprod Fertil 85:483-487, 1989.

318. Obasiolu CCW, Khan-Dawood FS, Dawood MY. IGF -1 receptors in human CL. Fertil Steril 57:1235-40, 1992.

319. Ohmichi M, Koike K, Kimura A, Masuhara K, Ikegami H, Ikebuchi Y, Kanzaki T, Touhara K, Sakaue M, Kobayashi Y, Akabane M, Miyake A, Murata Y. Role of mitogen-activated protein kinase pathway in prostaglandin F2alphainduced rat puerperal uterine contraction. Endocrinology 138(8):3103-11, 1997.

320. Ohtani M, Kobayashi S, Miyamoto A, Hayashi K, Fukui Y. Real time relationships between intraluteal and plasma concentration of ET, oxytocin and progesterone during PGF2 $\alpha$-induced luteolysis in the cow. Biol Reprod 58: 103108, 1998.

321. Okuda K, Sakimoto R. Multiple roles of TNF super family members in the CL function. Reprod Biol and Endocrinol I:95, 2003.

322. Okuda K, Uenoyama Y, Berisha B, Lange IG, Taniguchi H, Kobayashi Smiyamoto A, Schams D.Estradiol-17beta is produced in bovine CL. Biol Reprod 65:1634-39, 2001.

323. Okuda K, Korzekwa A, Shibaya M, Murakami S, Nishimura R,Tsubouchi M, Woclawek-Potocka I, Skarzynski DJ. Progesterne is a suppresser of apoptosis in bovie luteal cells. Bio Reprod 71:2065-2071, 2004.

324. Okuda K, Sakumoto R, Uenoyama Y, Berisha B, Miyamoto A, Schams D. TNF- $\alpha$ receptors in microvascular endothelial cells from bovine CL. Biol Reprod 61:1017-22, 1999.

325. Okuda K, Uneoyama Y. Oxytocin receptors and their physiological significance in ovary. In: Mityamoto H, Manabe N (eds), Reproductive Biology Update, Nakanishi Printing Co, Kyoto, Japan, P297-304, 1998.

326. Okuda K, Miyazaki Y, Takada J, Matsuyama K, Yamaki T, Yano M. Conversion of Big ET-1 by membrane bound metalloendopeptidase in cultured bovine endothelial cells. Biochem Biophys Res Commun 171:1192-98, 1990. 
327. Opgenorth T, Wu-Wong J, Shiosaki K. Endothelin converting enzyme. FASEB J 6:2653-59, 1992.

328. Orwig KE, Bertrand JE, Ou BR, Forsberg NE, Stormshak F. Immunochemical characterization and cellular distribution of protein kinase $\mathrm{C}$ isozymes in the bovine corpus luteum. Physiol Biochem Mol Biol 108: 53-57, 1994.

329. Otey CA, Kalnoski MH, Bulinski JC. Identification and quantification of actin isoforms in vertebrate cells and tissues. J Cell Biochem 34:113-124, 1987.

330. Ottobre JS, Lewis GS, Tahyne WV, Inskeep EK. Mechanisms by which progesterone shortens the estrous cycle of the ewe. Biol Reprod 23:1046-53, 1980.

331. Papadopoulos V, Amri H, Boujard N,Cascio C, Culty M, Garnier Mhardwick M, Li H, Vidic B, Brown AS, Reversa JL, Bernassau JM, Drieu K. PBR in cholesterol transport and steroidogenesis. Steroids 62:21-28, 1997a.

332. Papadopoulos V, Amri H, Li H, Boujard N, Vidic B, Garnier M. Targeted disruption of the PBR gene inhibits steroidogenesis in R2C Lleydig tumor cell line. J Biol Chem 272:32129-35, 1997 b.

333. Papadopoulos V, Brown AS. Role of the PBR and the polypeptide diazepam binding inhibitor in steroidogenesis. J Steroi Biochem Mol Bio 53:103$110,1995$.

334. Parent J, Fortier MA. Expression and contribution of three different isoforms of PGE synthase in the bovine endometrium. Biol Reprod DOI:10.1095/biolreprod.104.037036, 2005.

335. Parker KL, Schimmer BP. Steroidogenic factor I: a key determinant of endocrine development and function. Endocr rev 18:361-377 1997.

336. Parker PJ, Coussens L. Totty N, Rhee L, Young S, Chen E, Stabel S, Waterfield MD, Ullrich A. The complete primary structure of PKC-the major phorbol ester receptor. Science 233:859-866, 1986.

337. Pate JL. Intracellular communication in bovine CL. Theriogenology 45:1381-97, 1996. 
338. Pate JL. Involvement of immune cells in regulation of ovarian function. $\mathrm{J}$ Reprod Fertil 49:365-377, 1995.

339. Pate JL. Regulation of prostaglandin synthesis by P4 in the bovine CL. Prostaglandins36:303-315, 1988.

340. Pauken CM, Capco DG. The expression and stage-specific localization of PKC isotypes during mouse pre-implantation development. Dev Biol 223:411$421,2000$.

341. Peluso JJ, Pappalardo A, Losel R, Wehling M. Expression and function of PAIRBP1 within gonadotropin-primed immature rat ovaries: PAIRBP1 regulation of granulosa and luteal cell viability. Biol Reprod 73:261-70, 2005.

342. Penny LA, Armstrong D, Bramley A, Webb R, Collins RA, Watson ED. Immune cells and cytokine production in the bovine CL throughout the oestrous cycle and after induced luteolysis. J Reprod Fertil 115:87-9, 1999.

343. Perks CM, Denning-Kendall PA, Gilmour RS, Wathers DC. Localization of mRNA for IGF-I, IGF-II and the type 1 IGF receptor in the ovine ovary throughout the estrus cycle. Endocrinology 136:5266-73, 1995.

344. Pescador N, Soumano K, Stocco DM, Price CA, Murphy BD. StAR in bovine corpora lutea. Biol Repro 55:485-491, 1996.

345. Peters KE, Bergfeld EG, Cupp AS, Kojima FN, Mariscal V, SAMcHEZ T, Wehram ME, Grotjan HE, Hamernik DL, Kittok RJ, Kinder JE. LH has a role in development of fully functional CL but is not required to maintain CL function in heifers Biol Reprod 51:1248-54, 1994.

346. Petersen $\mathrm{CCH}$, Berridge MJ. The regulation of capacitative calcium entry by calcium and protein kinase $\mathrm{C}$ in Xenopus oocyte. J Biol Chem 269:32246$32253,1994$.

347. Pickett C A, Manning N, Akita Y, Gutierrez-Hartmann A. Role of specific protein kinase $\mathrm{C}$ isozymes in mediating epidermal growth factor, thyrotropinreleasing hormone, and phorbol ester regulation of the rat prolactin promoter in GH4/GH4C1 pituitary cells. Molecular Endocrinology 16: 2840-2852, 2002. 
348. Pierce KL, Bailey TJ, Hoyer PB, Gil DW, Woodward DF, Regan JW. Cloning of a carboxy-terminal isoform for the prostanoid FP receptor. JBC 272:883-887, 1997.

349. Pitzel L, Jarry H, Wuttke W. Effects and interactions of $\mathrm{PGF}_{2 \alpha}$, oxytocin and cytokines on steroidogenis of porcine luteal cells. Endocrinology 132: 751$756,1993$.

350. Plendl J, Neumuller C, Sinowatz F. Differences of microvascular endothelium in the bovine corpus luteum of pregnancy and the corpus luteum of the estrous cycle. Biol Cell 87:179-188, 1996a.

351. Plendl J, Neumuller C, Vollmar A, Auerbach R, Sinowatz F. Isolation and characterization of endothelial cells from different organs of fetal pigs. Anat Embyol 194:445-456, 1996b.

352. Plendl J. Angiogenesis and vascular regression in the ovary. Anatomia, Histologia, Embryologia 29:257-266, 2000.

353. Pratt BR, Butcher RL, Inskeep EK. Antiluteolytic effect of the conceptus and of PGE2 in ewes. J Anim Sci 45:784-91, 1977.

354. Prenant LA. La valeur morphologiyue du corps jaune. Son action physiologique et theripeutique possible (Abstract). Rev. Gen. Sci.Pures.Appl 9:646, 1898.

355. Principles of molecular regulation. Edited by Conn MP, Means AR.Humana Press, NJ

356. Pucci ML, Bao Y, Chan B, Itoh S, Lu R, Copeland NG, Gilbert DJ, Jenkins NA, Schuster VL.Cloning of mouse prostaglandin transporter PGT cDNA: species-specific substrate affinities. Am J Physiol 277:R734-41, 1999.

357. Putney JW Jr. Capacitative calcium revisited. Cell Calcium 11:611-624, 1990.

358. Putney JW Jr. A model for receptor-regulated calcium entry. Cell Calcium 7:1-12, 1986.

359. Quirk SM, Harman RM, Cowan RG. Regulation of Fas antigen (Fas, CD95)-mediated apoptosis of bovine granulose cells by serum and growth factors. Biol Reprod 63:1278-84, 2000. 
360. Rao CV, Mitra SB. Distribution of PGE and $\mathrm{PGF}_{2 \alpha}$. receptor proteins in the intracellular organelles of bovine CL. Methods Enzymol 86:192-202, 1982.

361. Ratcliffe KE, Anthony Fw, Richardson MC, Stones RW. Morphology and functional characteristics of human ovarian microvascular endothelium. Hum Reprod 14: 1549-1554, 1999.

362. Raw RE, Currie TE, Silvia WJ. Effects of progesterone and oestrsdiol on the concentration and activity of cyclooxygenase in the ovine uterus (abstract). Biol Reprod 38 (Suppl) 1: A104, 1988.

363. Ray A, Fields AP, Ray BK. Activation of transcription factor SAF involves phosphorylation by PKC. J Biol Chem 50:39727-33, 2000.

364. Redmer DA, Reynolds LP. Angiogenesis in the ovary. Rev.Reprod 1:182$192,1996$.

365. Redmer DA, Grazul AT, Kirsch JD, Reynolds LP. Angiogenic activity of bovine CL at several stages of luteal development. J. Reprod. Fertil 82:627-634, 1988.

366. Reinhart AJ, Williams SC, Stocco DM. Transcriptional regulation of the StAR gene. Mol Cell Endocrinol 177:55-59, 1999.

367. Reynolds LP, RedmerDA. Growth and development of the CL. J.Reprod. Fertil 54:181-191, 1999.

368. Reynolds LP, Redmer DA. Expression of the angiogenic factors, bFGF and VEGF in the ovary. J. Anim Sci 76:1671-81, 1998.

369. Reynolds LP, Killilea SD, Grazul-Bilska AT, Redmer DA. Mitogenic factors of corpora lutea. Progress in Growth Factor Research 5:159-175, 1994.

370. Reynolds LP, Killilea SD, Redmer DA. Angiogenesis in the female reproductive system. FASEB J 6:886-892, 1992.

371. Reynolds LP, Stigler J, Hoyer GL, Magness RR, Huie JM, Huecksteadt TP, Whysong G, Behrman HR, Weems CW. Effect of PGE1 on PGF2 $\alpha$ induced luteolysis in nonbred ewes. Prostaglandins 21:957-72, 1981.

372. Rice GE. Biophysical characteristics of oxytocin secretory granules isolated from ovine CL. J Endocrinol 116:267-272, 1988. 
373. Ricken AM, Spanel-Borowski K, Saxer M, Huber PR. Cytokeratin expression in bovine corpora lutea. Histochem Cell Biol 103:345-354, 1995.

374. Rodgers RJ, O'Shea JD. Purification, morphology and progesterone production and content of three cell types isolated from the corpus luteum of the Sheep. Aust J Biol Sci 35:441-455, 1982.

375. Rodway MR, Swan CL, Crellin NK, Gillio-Meina C, Chedrese PJ. Steroid regulation of progesterone synthesis in a stable porcine granulosa cell line: a role for progestins. J Steroid Biochem Mol Biol 68:173-180; 1999.

376. Ron D, Kazanietz MG. New insights into the regulation of PKC and novel phorbol ester receptors. FASEB 13:1658-76, 1999.

377. Rothchild I. The regulation of the mammalian CL. Recent Progress in Hormone Research 37:183-298, 1981.

378. Rowson LE, Tervit R, Brand A. The use of prostaglandins for synchronization of oestrus in cattle. J Reprod Fertil 29:145-146, 1972.

379. Rueda BR, Hendry IR, Hendry WJ Jr, Stromshak F, Slayden OD, Davis JS. Decreased P4 levels and P4 receptor antagonists promote apoptotic cell death in bovine luteal cells. Biol Reprod 62:269-276, 2000.

380. Rust W, Stedronsky K, Tillmann G, Morley S, Walther N, Ivell R The role of SF-1/Ad4BP in the control of the bovine gene for StAR protein. J. MOL.Endocrinol 21:189-200, 1998.

381. Sakamoto K, Ishii Y, Onodera T, Sugano T. Cloning and characterization of novel isoforms of $\mathrm{PGF}_{2 \alpha}$ receptor in the bovine CL. Dna Seq 13:307-11, 2002.

382. Sakamoto K, Miwa K, Ezashi T, Okuda-Ashitaka E, Okuda K, Houtani T, Sugimoto $\mathrm{T}$, Ito $\mathrm{S}$, Hayaishi $\mathrm{O}$. Expression of mRNA encoding the $\mathrm{PGF}_{2 \alpha}$ receptor in bovine CL throughout the estrous cycle and pregnancy. J Reprod Fertil 103:99-105, 1995.

383. Sakamoto K, Ezashi T, Miwa K, Okuda-Ashitaka E, Houtani T, Sugimoto T, Ito S, Hayaishi O. Molecular cloning and expression of a cDNA of the bovine PGF $_{2 \alpha}$ receptor. JBC 269:3881-3886, 1994. 
384. Sakanoue Y, Hatada T, Horai T, Shoji Y, Kusumoki M, and Utsanomiya J.

Protein kinase $\mathrm{C}$ activity of colonic mucosa in ulcerative colitis. Scand $\mathrm{J}$. Gastroentero 1992; 27(4): 275-80.

385. Sakumoto R, Okuda K. Possible actions of TNF- $\alpha$ in ovarian function. $\mathrm{J}$ Reprod Dev 50:39-46, 2004.

386. Sakumoto R, Berisha B, Kawate N, Schams D, Okuda K. TNF- $\alpha$ and its receptor in the bovine CL throughout the estrous cycle. Biol Reprod 62: 192-199, 2000.

387. Sakumoto R, Ando Y, Okuda K. P4 release of bovine CL in response to oxytocin in different culture systems. J Reprod Dev 42:199-204, 1996.

388. Salli U, Supancic S, Stormshak F. Phosphorylation of MARCKS protein is associated with bovine luteal oxytocin exocytosis. Biol Reprod 63: 12-20, 2000.

389. Sandoff TW, Hales DB, Hales KH, McLean MP. Transcriptional regulation of the rat StAR by SF 1. Endocrinology 139:4820-31, 1998.

390. Sauerwien H, Miyamoto A, Gunther J, Meyer HHD, Schams D. Binding and action of IGF and insulin in bovine luteal tissue during the oestrus cycle. $\mathrm{J}$ Reprod Fertil 96:103-115, 1992.

391. Savouret JF, Guiochon-Mantel A, Milgrom E. Uteroglobin gene, structure and interaction with P4-receptor. Oxf Surv Eukaryot Genes 1:192-214, 1984.

392. Sawyer HR, Niswender KD, Braden TD, Niswender GD. Nuclear changes in ovine luteal cells and progesterone secretion by ovine CL in response to $\mathrm{PGF}_{2 \alpha}$ . Domest Anim Endocrinol 7:229-238, 1990.

393. Sayre BL, Taft R, Inskeep EK, Killefer J. Increased expression of insulinlike growth factor binding protein-1 during induced regression of bovine corpora lutea. Biol Reprod 63: 21-29, 2000.

394. Scallen TJ, Pastuszyn A, Noland BJ, Chanderbhan R, Kharroubi A, Vahouny GV. Sterol carrier and lipid transfer proteins. Chem.Phys.Lipids 38:239$261,1985$.

395. Schams D, Berisha B. Regulation of CL function in cattle-an overview. Reprod Dom Anim 39:241-251, 2004. 
396. Schams D, Berisha B, Kosmann M, Amselgruber W. Expression and localization of IGF family members in bovine antral follicle during final growth and in luteal tissue during different stages of estrous cycle and pregnancy. Domest Anim Endocrinol 22:51-72, 2002a.

397. Schams D, Berisha B. Steroids as local regulators of ovarian activity in domestic animals. Domest Anim Endocrinol 23:53-65, 2002 b.

398. Schams D, Berisha B. Regulatory factors for luteolysis in ruminants. Arch Tierz 44:51-53, 2001.

399. Schams D, Kotwica J, Wlger W. The importance of progesterone for the timing of luteolysis and oestrous cycle length in sheep and cow. Exp Clin Endocrinol Diabetes 106:S9, 1998.

400. Schams D. Paracrine/autocrine regulation of bovine CL function. J Reprod Dev 42 (Suppl) 54-57, 1996.

401. Schams D, Liebermann J, Miyamoto A. Luteotropic role of bovine luteal oxytocin in vitro. Adv Exp Med Biol 395:543-544, 1995 a.

402. Schams D, Schimidt K, Schlegel W. Effects of growth factors on prostaglandin secretion of bovine luteal cells in vitro at different stages of the luteal phase. Biol Reprod 52(Supple):569, 1995b.

403. Schams D, Amselgruber W, Einspanier R, Sinowatz F, Gospodarowicz D. Localization and tissue concentration of bFGF in the bovine CL. Endocrine 2:907-912,1994.

404. Schams D. Regulation of bovine intra-luteal function by peptide hormones. J Physiol Pharmacol 43:117-129, 1992.

405. Schams D, Muller M, Brem G. Tissue concentration mRNA expression and stimulation of IGF-1 in luteal tissue during the oestrous cycle and pregnancy of cows. J Reprod Fertil 90:439-445, 1990.

406. Schams D. Luteal peptides and intracellular communication. J Reprod Fertil 34 (Suppl), 87-99, 1987.

407. Schauser KH, Neilsen AH, Winther H, Dantzer V, Poulsen K. Localization of the renin-angiotensin system in the bovine ovary:cyclic variation of the angiotensin II receptor expression. Biol Reprod 65:1672-80, 2000. 
408. Schmitz-Sapanke S, Schipke JD. Potential role of endothelin -1 and endothelin antagonists in cardiovascular diseases. Basic Res Cardiol 195:290-8, 2000.

409. Schuster VL. Prostaglandin transport. Prostaglandins Other Lipid Mediat 68-69:633-47, 2002.

410. Schuster VL. Molecular mechanisms of prostaglandin transport. Annu Rev Physiol 60:221-42, 1998.

411. Schwarzenbach H, Manna PR, Stocco DM, Chakraborti G, Mukhopadhyay AK. Stimulatory effect of progesterone on the expression of StAR protein in MA-10 Leydig cells. Biol Reprod 68:1054-63, 2003.

412. Selzer E, Okomoto I, Lucas I, Kodym R, Pehamberger H, and Jansen B. Protein kinase $\mathrm{C}$ isoforms in normal and transformed cells of the melanocytic lineage. Melanoma Res 12(3): 201-209, 2002.

413. Sen A, Browning J, Inskeep EK, Lewis P, Flores JA. Expression and activation of protein kinase $\mathrm{C}$ isozymes by prostaglandin F2 $\alpha$ (PGF2 $\alpha$ ) in the early and mid-luteal phase bovine corpus luteum. Biol Reprod 70:379-384, 2004.

414. Sen A, Choudhary E, Inskeep EK, Flores JA. Effects of selective PKC isozymes in $\mathrm{PGF}_{2 \alpha}$-induced calcium signaling and $\mathrm{LH}$ induced progesterone accumulation in the mid-phase bovine corpus luteum. Biol Reprod 72:976-984, 2005.

415. Serneri GG, Cecioni I, Vanni S, Paniccia R, Bandinelli B, Vetere A, Janming X, Bertolozzi I, Boddi M, Lisi GF. Selective upregulation of cardiac endothelin system in patients with ischemic but not idiopathic dialated cardiomyopathy: ET-1 system in the human failing heart. Cir Res 86:377-85, 2000.

416. Shalaby F, Rossant J, Yamaguchi TP,Gertsenstein M, Schuh AC. Failure of blood-island formation and vasculogenesis in FLK-1 deficient mice. Nature 376:62-66, 1995.

417. Sharma RC, Fitzpatrick RJ. Effect of oestradiol-17 $\beta$ and oxytocin treatment on PGF2 $\alpha$ release in the anoestrous ewe. Prostaglandins 6:97-105, 1997. 
418. Shaw DW, Britt JH. In vivo oxytocin release from microdialyzed bovine CL during spontaneous and prostaglandin-induced regression. Biol Reprod 62:726-730, 2000.

419. Shaw DW, Britt JH. Concentrations of TNF- $\alpha$ and progesterone within the bovine CL sampled by continuous flow microdialysis during luteolysis in vivo. Biol Reprod 53:847-854, 1995.

420. Sheffel CE, Pratt BR, Ferrell WL, Inskeep EK. Induced corpora lutea in the postpartum cow. II. Effects of treatment with progesterone and gonadotropins. J Anim Sci 54:830-836, 1982.

421. Silavin SL, Moss GE, Niswender GD. Regulation of steroidogenesis in the ovine corpus luteum. Steroids 36:229-241, 1980.

422. Silva PJ, Juengel JL, Rollinson MK, and Niswender GD. Prostaglandin metabolism in the ovine corpus luteum: catabolism of prostaglandin $\mathrm{F}_{2 \alpha}\left(\mathrm{PGF}_{2 \alpha}\right)$ coincides with resistance of the corpus luteum to $\mathrm{PGF}_{2 \alpha}$. Biol Reprod 63: 1229$1236,2000$.

423. Silverman E, Eimer S, Orly J. CCAAT enhancer binding protein beta and GATA-4 binding regions within the promoter of the StAR protein gene are required for transcription in rat ovarian cells. J Biol Chem 274:17987-96, 1999.

424. Silvia WJ, Niswender GD. Maintenance of the CL of early pregnancy in the ewe. IV. Changes in luteal sensitivity to PGF2 $\alpha$ through out early pregnancy. J Anim Sci 63: 1201-07, 1986.

425. Simon LS. Role and regulation of Cox-2 during inflammation. A J Med 106:37S-42S, 1999.

426. Simonson MS, Wann S, Mene P, Dubyak GR, Kester M, NakazatoY, Sedor JR, Dunn MJ. Endothelin stimulates PLC, Na+ / H+ exchange, c-fos expression and mitogenesis in rat mesangial cells. J Clin Invest 83:708-712, 1989. 427. Six DA, Dennis EA. The expanding super family of $\mathrm{PLA}_{2}$ enzymes: classification and characterization. Biochem Biophys Acta 1488:1-19, 2000.

428. Skarzynski DJ, Jaroszewski JJ, Bah MM, Deptula KM, Barszczewska B, Gawronska B, Hansel W. Administration of a NO synthase inhibitor counteracts $\mathrm{PGF}_{2 \alpha}$-induced luteolysis in cattle. Biol Reprod 68:1674-81, 2003. 
429. Skarzynski DJ, Jarosezewski JJ, Okuda K. Luteotropic mechanisms in the bovine CL: role of OT, PGF2 $\alpha$ P4 and noradrenalin. J Reprod Dev 47:125-137, 2001.

430. Skarzynski DJ, Kobayashi S, Okuda K. Influence of nitric oxide and noradrenaline on $\mathrm{PGF}_{2 \alpha}$ - induced oxytocin secretion and intracellular calcium mobilization in cultured bovine luteal cells. Biol Reprod 63: 1000-1005, 2000.

431. Skarzynski DJ, Okuda K. Sensitivity of bovine CL to PGF2 $\alpha$ is dependent on P4, OT and prostaglandins. Biol Reprod 60:1292-98, 1999.

432. Skarzynski DJ, Miszkiel G, Bogacki M, Kotwica J. Influence of P4 on its own synthesis and secretion from the CL during estrous cycle and pregnancy of cattle. Folia Histochem Cytobiol 35(suppl 2): P-033 abstract; 1997.

433. Skarzynski D, Kotwica J. Mechanism of noradrenaline influence on the secretion of ovarian OT and P4 in conscious cattle. J Reprod Fertil 97:419-424, 1993.

434. Smeets RL, Rao RV, van Emst-de Vries SE, de Pont JJ, Miller LJ, Willems PH. Reduced cholecyctokinin receptor phosphorylation and restored signaling in protein kinase $\mathrm{C}$ down-regulated rat pancreatic acinar cells. Pflugers Arch 435:422-428, 1998.

435. Smith CJ, Sridaran R. Time-dependent biphasic effect of cytochalasin D on luteal progesterone release in the pregnant rat. Life Sci 48:1217-25, 1991.

436. Sohn UD, Zoukhri D, Dartt D, Sergheraert C, Harnett KM, Behar J, Biancani P. Different protein kinase C isozymes mediate lower esophageal sphincter tone and phasic contraction of esophageal circular smooth muscle. Mol Pharmacol 51:462-470, 1997.

437. Soloff MS. Uterine receptors for oxytocin:effect of estrogen. Bio Biophys Res Commun 65:205-212, 1975.

438. Soltta KH, Ruschig H, Fels E Reindarstellung der hormone aus dem corpus luteum. Berich.Dtsch.Chem.Geselischaft 67:1270, 1934.

439. Song SK, Choi SY, Kim KT. Opposing effects of protein kinase A and C on capacitative calcium entry into HL-60 promyelocytes. Biochem Pharmacol 56:561-567, 1998. 
440. Spanel-Borowski K, Fenyves A. The heteromorphology of cultured microvascular endothelial cells. Arzneimittelforschung 44:385-391, 1994a.

441. Spanel-Borowski K, Ricken AM, Kress A, Huber PR. Isolation of granulosa-like cells from the bovine secretory CL and their characterization in long term culture. Anat Rec 239:269-279, $1994 b$.

442. Spanel-Borowski K, Ricken AM, Patton WF. Cytokeratin-positive and cytokeratin-negative cultured endothelial cells from bovine aorta and vena cava. Differentiation 57:225-234, 1994c.

443. Spanel-Borowski K. Diversity of ultrastructure in different phenotypes of cultured microvessel endothelial cells isolated from bovine CL. Cell Tissue Res 266:37-49, 1991.

444. Spanel-Borowski K, van der Bosch J. Different phenotypes of cultured microvessel endothelial cells obtained from bovine CL. Study by light microscopy and by SEM. Cell Tissue Res 261:37-49, 1990.

445. Spicer LJ, Ireland JJ, Roche JF. Changes in serum LH, progesterone and specific binding of 125I-hCG to luteal cells during regression and development of bovine corpora lutea. Biol Reprod 25:832-841, 1981.

446. Srinivasan D, Fujino H, Regan JW. Differential internalization of the prostaglanding $\mathrm{F}_{2}$ receptor isoforms: role of protein kinase $\mathrm{C}$ and Clathrin. $\mathrm{J}$ Pharmacology and Experimental Therapeutics 302: 219-224, 2002.

447. Statistical software for the Apple Macintosh. JMP Statistics and Graphics Guide, Version 3.0 of JMP. Cary, NC: Statistical Analysis System Institute, Inc.; 1994.

448. Stevens VL, Xu T, Lambeth JD. Cholesterol trafficking in steroidogenic cells: reversible cycloheximide-dependent accumulation of cholesterol in a presteroidogenic pool. Eur.J.Biochem 216:557-563, 1993.

449. Stirling D, Magness RR, Stone R, Waterman MR, Simpson ER. Angiotensin II inhibits LH-stimulated cholesterol side chain cleavage expression and stimulates bFGF expression in bovine luteal cells in primary culture. J Biol Chem 265:5-8, 1990. 
450. Stocco DM, Clark BJ. Regulation of the acute production of steroids in steroidogenic cells. Endocrine Reviews 17:221-244, 1996.

451. Stojilkovic SS, Balla T, Fukuda S, Cesnjaj M, Merelli F, Krsmanovic LZ, Catt KJ. Endothelin ETA receptors mediate the signaling and secretory actions of endothelins in pituitary gonadotrophs. Endocrinology 130:465-474, 1992.

452. Strauss JF, Liu P, Christenson LK, Watari H. Sterols and intracellular vesicular trafficking:leasons from the study of NPC1.Steroids 67:947-951, 2002.

453. Sugawara T, Lin D, Holt JA, Martin KO, Javitt NB, Miller WL, Strauss JF. Structure of the human StAR gene: StAR stimulates mitocohondrial cholesterol 27-hydroxylase activity. Biochem 34:12506-12, 1995.

454. Sugimoto Y, Hasumoto K, Namba T, Irie A, Katsuyana M, Negishi M, Kakizuka A, Narumiya S, Ichikawa A. Cloning and expression of a cDNA for mouse $\mathrm{PGF}_{2 \alpha}$ receptor. JBC 269:1356-60, 1994.

455. Sugita K, Mork AC, Zhang GH, Martinez JR. Modulation of calcium mobilization by PKC in the submandibular duct cell line A253. Mol Cell Biochem 198:39-46, 1999.

456. Suzuki T, Fujii Y, Miyano M, Chen LY, Takahashi T, Watanabe K. cDNA cloning, expression, and mutagenesis study of liver-type prostaglandin F synthase. J Biol Chem 274:241-8, 1999a.

457. Suzuki-Yamamoto T, Nishizawa M, Fukui M, Okuda-Ashitaka E, Nakajima T, Ito S, Watanabe K. cDNA cloning, expression and characterization of human prostaglandin F synthase. FEBS Lett 462:335-40, $1999 \mathrm{~b}$.

458. Tandeski TR, Juengel JL, Nett TM, Niswender GD. Regulation of mRNA encoding LDL receptor and HDL binding protein in ovine CL. Reprod Fertil Dev 8:1107-1114, 1996.

459. Taniguchi H et al, 2002; Pru JK, Hendry IR, Davis JS, Rueda BR. Soluble Fas ligand activates the sphingomylein pathway and induces apoptosis in luteal steroidogenic cells independently of stress activated p38 MAPK. Endocrinoogy $143: 4350-57,2002 \mathrm{a}$.

460. Taniguchi H, Tokomizo Y, Okuda K. Fas/Fas ligand mediates luteal cell death in bovine CL. Biol Reprod 66:754-759, 2002 b. 
461. Tanioka T, Nakatani Y, Semmyo N, Murakami M, Kudo I. Molecular identification of cytosolic prostaglandin E2 synthase that is functionally coupled with Cox-1 in immediate prostaglandin E2 biosynthesis J Biol Chem 275:32775$82,2000$.

462. The'odore L, Derossi D, Chassaing G, Llirbat B, Kubes M, Jordan P, Chneiweiss H, Godement P, Prochiantz A. Intraneural delivery of protein kinase C pseudosubstrate leads to growth cone collapse. J Neurosci 15:7158-7167, 1995. 463. Theodosis DT, Wooding FBP, Sheldrick EL, Flint APF. Ultastructural localization of oxytocin and neurophysin in the ovine CL. Cell Tissue Res 243:129-135, 1986.

464. Thodeti CK, Nielsen CK, Paruchuri S, Larsson C, Sjolander A. The epsilon isoform of PKC is involved in regulation of the LTD4-induced calcium signal in human intestinal epithelial cells. Exp Cell Res 262:95-103, 2001.

465. Tognetti T, Estevez A, Luchetti CG, Sander V, Franchi AM, Motta AB. Relationship between endothelin-1 and nitric oxide system in the corpus luteum regression. Prostaglandins Leukot Essent Fatty Acids 69:359-364, 2003.

466. Townson DH, Pate JL. Mechanism of action of TNF- $\alpha$ stimulated prostaglandin production in cultured bovine luteal cells. Prostaglandins 52:361$373,1996$.

467. Townson DH, Pate JL. Regulation of prostaglandin synthesis by interleukin-1 $\beta$ in cultured bovine luteal cells. Biol Reprod 51:480-485, 1994.

468. Tremblay JJ, Viger RS. Transcription factor GATA-4 is activated by phosphorylation of serine 261 via the cAMP/PKA signaling pathway in gonadal cells. J Biol Chem 2003.

469. Tremblay JJ, Hamel F, Viger RS. PKA-dependent cooperation between GATA and CCAAT/enhancer binding protein transcription factors regulates StAR protein promoter activity. Endocrinology 143:3935-45, 2002.

470. Tsai SJ, Kot K, Ginther OJ, Wiltbank MC. Temporal gene expression in bovine CL after treatment with PGF2 $\alpha$ based on serial biopsies in vivo. Reproduction 121:905-913, 2001a. 
471. Tsai SJ, Wiltbank MC. Differential effets of PGF 2 alphaon in vitro luteinized granulosal cells. Reproduction 122:245-243, $2001 \mathrm{~b}$.

472. Tsai SJ, Wiltbank MC. PGF2 $\alpha$ regulates distinct physiological changes in early and mid-cycle bovine CL. Biol Reprod 58:346-352, 1998.

473. Tsai SJ, and Wiltbank MC. Prostraglandin F2 $\alpha$ induces expression of prostaglandin $\mathrm{G} / \mathrm{H}$ synthetase-2 in the ovine corpus luteum: a potential positive feedback loop during luteolysis. Biol Reprod 57: 1016-1022, 1997.

474. Tsai SJ, Wiltbank MC, Bodensteiner KJ. Distinct mechanisms regulate induction of mRNA for prostaglandin (PG) G/H synthase-2, PGE (EP3) receptor and $\mathrm{PGF}_{2 \alpha}$ receptor in bovine preovulatory follicles. Endocrinology 136:3348$3355,1996$.

475. Tscheudschilsuren G, Aust G,Nieber K, Schilling N, Spanel-Borowski K. Microvascular endothelial cells differ in basal and hypoxia-regulated expression of angiogenic factors and their receptors. Microvasc Res 63:243-251, 2002.

476. Tsigkos S, Koustsilieris M, Papapetropoulos A. Angiopoietins in angiogenesis and beyond. Expert Opin Investig Drugs 12:933-941, 2003.

477. Vallet JL, Lamming GE, Batten M. Control of endometrial oxytocin receptor and uterine response to oxytocin by progesterone and estradiol in the ewe. J Reprod Fertil 90:625-634, 1990.

478. Vaskivuo TE, Ottander U, Oduwole O, Isoma V, Vihko P, Olofsson JL, Tapanainen JS. Role of apoptosis, apoptosis-related factors and 17-beta hydroxysteroid dehydrogenase in human CL regression. Mol Cell Endocrinol 194:191-200, 2002.

479. Vegesna RV, Mong S, Crooke ST. Leukotriene D4 induced activation of PKC in rat basophilic leukemia cells. Eur J Pharmacol 147:387-396, 1998.

480. Vives E, Brodin P, Lebleu B. A truncated HIV-1 Tat protein basic domain rapidly translocates through the plasma membrane and accumulates in the cell nucleus. J Biol Chem 272:16010-16017, 1997.

481. Vu Hai MT, Logeat F, Warembourg M, Milligrom E. Hormonal control of progesterone receptors. Ann NY Acad Sci 286:199-209, 1977.

482. Voet D, Voet JG. Biochemistry. Second edition: 691-704, 1995. 
483. Watanabe K, Kurihara K, Suzuki T. Purification and characterization of membrane bound prostaglandin E Synthase from bovine heart. Biochem Biophys Acta 1439:406-414, 1999.

484. Watanabe K, Iguchi Y, Iguchi S, Arai Y, Hayaishi O, Roberts LJ 2nd. Stereospecific conversion of prostaglandin D2 to (5Z, 13E)-(15S)-9 alpha-11 beta,15-trihydroxyprosta-5,13-dien-1-oic acid (9 alpha,11 beta-prostaglandin F2) and of prostaglandin $\mathrm{H} 2$ to prostaglandin $\mathrm{F} 2$ alpha by bovine lung prostaglandin $\mathrm{F}$ synthase. PNAS 83:1583-7, 1986.

485. Watanabe K, Yoshida R, Shimizu T, Hayaishi O. Enzymatic formation of prostaglandin $\mathrm{F} 2$ alpha from prostaglandin $\mathrm{H} 2$ and $\mathrm{D} 2$. Purification and properties of prostaglandin F synthetase from bovine lung. J Biol Chem 260:7035-41, 1985.

486. Watari H, Arakane F, Moog-Lutz C,Kallen CB, Tomasetto C, Gerton GL, Rio M, Baker ME, Strauss JF. MLN 64 contains a domain with homology to the StAR protein that stimulates steroidogenesis. PNAS 94:8462-67, 1997.

487. Watson J, Shepherd TS, Dodson KS. Prostaglandin E2-9-ketoreductase in ovarian tissues. J Reprod Fert 57:489-496, 1979.

488. Webb BL, Lindsay MA, Seybold J, Brand NJ, Yacoub MH, Haddad EB, Barnes PJ, Adcock IM, Giembycz MA. Identification of the protein kinase C isoenzymes in human lung and airways smooth muscle at the protein and mRNA level. Biochem. Pharmacol 54:199-205, 1997.

489. Wegner JA, Martinez-Zaguilan R, Gillies RJ, Hoyer PB. PGF $2 \alpha$-induced calcium transient in ovine large luteal cells:II. Modulation of the transient and resting cytosolic free calcium alters progesterone secretion. Endocrinol 128: 929936, 1991.

490. Wegner JA, Martinez-Zaguilan R, Wise ME, Gillies RJ, Hoyer PB. Prostaglandin F2 alpha-induced calcium transient in ovine large luteal cells: I. Alterations in cytosolic-free calcium levels and calcium flux. Endocrinology 127:3029-3037, 1990.

491. Williams MT, Marsh JM. Cytochalasin B inhibition of luteinizing hormone action on bovine luteal cells. Adv EXP Med Biol 112:549-554, 1979. 
492. Willoughby DA, Moore AR, Colville-Nash PR. Cox-1, Cox-2 and Cox-3 and the future treatment of chronic inflammatory disease. Lancet 355:646-648, 2000.

493. Wiltbank MC, Ottobre JS. Regulation of intraluteal production of prostaglandins. Reproductive Biology and Endocrinology I: 91, 2003.

494. Wiltbank C, Shia OJF, Bergfelt DR, Ginther OJ. PGF2 $\alpha$ receptor in the early bovine CL. Biol Reprod 52:74-78, 1995.

495. Wiltbank M C. Cell types and hormonal mechanisms associated with mid cycle CL function. J Anim Sci 72:1873-83, 1994.

496. Wiltbank MC, Belfiore CJ, Niswender GD. Steroidogenic enzyme activity after acute activation of PKA and PKC in ovine small and large luteal cells. Mol Cell Endo 97:1-7, 1993.

497. Wiltbank MC, Diskin MG, Niswender GD. Differential actions of secondary messengers in the CL. J Reprod Fertil Suppl 43:65-75, 1991.

498. Wiltbank MC, Diskin MG, Flores JA, Niswender GD. Regulation of the corpus luteum by protein kinase C. II. Inhibition of lipoprotein-stimulated synthesis by prostaglandin F2 alpha. Biol Reprod 42:239-245, 1990.

499. Wiltbank MC, Guthrie PB, Mattson MP, Ater SB, Niswender GD. Hormonal regulation of free intracellular calcium concentrations in small and large ovine luteal cells. Biol Reprod 41:771-778, 1989a.

500. Wiltbank MC, Knickerbocker JJ, Niswender GD. Regulation of the CL by PKC.I. Phosphorylation activity and steroidogenic action in large and small luteal cells. Biol Reprod 40:194-20, 1989b.

501. Wintergalen N, Thole HH, Galla HJ, Schelegel W. ProstaglandinE2-9reductase from CL of pseudopregnant rabbit $\mathrm{I}$ a member of the aldo-keto reductase superfamily featuring $20 \alpha$ hydroxysteroid dehydrogenase activity. Eur J Biochem 234:264-270, 1995.

502. Wintersteiner O, Allen WN. Crystalline progestin. J.Biol.Chem 107:321336, 1934. 
503. Wlodawer O, Kindahl H, Hamberg M. Biosynthesis of prostaglandin F2 $\alpha$, from arachidonic acid and prostaglandin endoperoxides in the uterus. Biochem Biophys Acta 431:603-614, 1976.

504. Wofl KW, Spanel-Borowski K. The interphase microtubule cytoskeleton of five different phenotypes of microvessel endothelial cell cultures derived from bovine CL. Tissue Cell 24:347-354 1992.

505. Woody CO, First NL, Pope AL. Effect of exogenous progesterone on estrous cycle. J Anim Sci 26:139-141, 1967.

506. Wooton-Kee CR, Clark BJ. SF 1 influences protein-DNA interactions within cAMP-responsive regions of the murine StAR protein gene. Endocrinology 141:1345-55, 2000.

507. Wright MF, Sayre B, Inskeep EK, Flores JA. PGF2 $\alpha$ regulation of the bovine CL endothelin system during early and mid luteal phase. Biol Reprod 65:1710-17, 2001.

508. Wu WX, Ma XH, Yoshizato T, Shinozuka N, Nathanielsz PW. Increase in prostaglandin $\mathrm{H}$ synthase 2 , but not prostaglandin F2alpha synthase mRNA in intrauterine tissues during betamethasone-induced premature labor and spontaneous term labor in sheep. J Soc Gynecol Investig. 8:69-76, 2001.

509. Wu XM, Carlson JC. Alterations in PLA2 activity during luteal regression in pseudopregnant and pregnant rats. Endocrinology 127:2464-68, 1990.

510. Wu YL, Wiltbank MC. Transcriptional regulation of Cox-2 gene changes from PKA to PKC dependence after luteinization of granulosal cells. Biol Rerod 66:1505-14, 2002.

511. Wu YL, Wiltbank MC. Differential regulation of prostaglandin endoperoxide synthase-2 transcription in ovine granulosa and large luteal cells. Prostaglandins Other Lipid Mediat 65:103-116, 2001.

512. Wuttke W, Pitzel L, Knoke I, Theiling K Jarry H. Immune-endocrine interactions affecting luteal function in pigs. J Reprod Fertil Suppl 52:19-29, 1997. 
513. Xiao CW, Asselin E, Tsang BK. NFkB-mediated induction of flice-like inhibitory protein prevents TNF-alpha induced apoptosis in rat granulose cells. Biol Reprod 67:436-441, 2002.

514. $\mathrm{Xu} \mathrm{Y,} \mathrm{Ware} \mathrm{JA.} \mathrm{Selective} \mathrm{inhibition} \mathrm{of} \mathrm{thrombin} \mathrm{receptor-mediated}$ calcium entry by PKC ß. J Biol Chem 270:23887-23890, 1995.

515. Yamamoto H, Endo T, Kiya T, Goto T, Sagae S, Ito E, Watanabe H, Kudo R. Activation of phospholipase $\mathrm{D}$ by prostaglandin $\mathrm{F}_{2 \alpha}$ in rat luteal cells and effects of arachidonic acid metabolism. Prostaglandins 50: 201-211, 1995.

516. Yanagisawa M. ECE-2 is a membrane bound, phosphoramidon-sensitive metalloprotease with acidic pH optimum. JBC 270:15262-15268, 1995.

517. Yanagisawa M, Kurihara H, Kimura S, Mitsui Y, Kobayashi M, Watanabe TX, Masaki T. A novel potent vasoconstrictor peptide produced by vascular endothelial cells. Nature 332:411-415, 1988.

518. Yancopoulos GD, Davis S,Gale NW, Rudge JS, Wiegand SJ, Holash J. Vascular-specific growth factors and blood vessel formation. Nature 407:242-248, 2000.

519. Yedovitzky M, Mochly-Rosen D, Johnson JA, Gray MO, Ron D, Abramovitch E, Cerasi E, Nescher R. Translocation inhibitors define specificity of protein kinase C isozymes in pancreatic $\beta$ cells. J Biol Chem 272:1417-1420, 1997.

520. Ying Hefner, Angelika G. Börsch-Haubold, Makomoto Murakami, Jonathan I. Wilde, Sophie Pasquet, David Schieltz, Farideh Ghomashchi, John R. Yates, III, Christopher G. Armstrong, Andrew Paterson, Philip Cohen, Rikiro Fukunaga, Tony Hunter, Ichiro Kudo, Steve P. Watson, Michael H. Gelb. Serine 727 Phosphorylation and Activation of Cytosolic Phospholipase A2 by MNK1related Protein Kinases. J Biol Chem 275: 37542-37551, 2000.

521. Yuan W, Connor ML. Protein kinase $\mathrm{C}$ activity and its effect on progesterone production by large and small porcine luteal cells. Proc Soc Biol Med 216:86-92, 1997. 
522. Zachow R, Terranova P. Involvement of PKC and protein tyrosine kinase pathways TNF- $\alpha$ induced clustering of ovarian theca-interstitial cells. Mol Cell Endocrinol 97:37-49, 1993a.

523. Zachow R, Tash J, Terranova P. TNF- $\alpha$ attenuation of LH-stimulated androstenedione production by ovarian theca-interstitial cells: Inhibition at loci with in the AMP dependent signaling pathway. Endocrinology 133:2269-76, $1993 b$.

524. Zazopoulos E, Lalli E, Stocco DM, Sassone-Corsi P. DNA binding and transcriptional repression of DAX-1 blocks steroidogenesis. Nature 390:311-315, 1997.

525. Zeleznik AJ, Benyo DF. Control of follicular development, CL function and the recognition of pregnancy in higher primates. The Physiology of Reproduction ( $2^{\text {nd }}$ edition) edited by Ernest Knobil and JD neill. New York:Raven: 751-782, 1994.

526. Zelinski MB, Nowek P, Weber DW, Stromshak F. Characterization of cytoplasmic progesterone receptors in the bovine endometrium during proestrus and diestrus. J Anim Sci 55:376-383, 1982.

527. Zhao Y, Burbach JA, Roby KF, Terranova PF, Brannian JD. Macrophages are the major source of TNF- $\alpha$ in the porcine CL. Biol Reprod 59:1385-91, 1998.

528. Zheng J, Redmer DA, Reynolds LP. Vascular development and heparinbinding growth factors in the bovine CL at several stages of the estrous cycle. Biol Reprod 49:1177-89, 1993. 


\section{Resume:}

Aritro Sen

53 Campus Drive, LSB

Department of Biology (CMB program),

Eberly College of Arts and Sciences

WVU, Morgantown, WV 26506, USA

Ph \# (304) 2935201 ext 31466/31536

aritros@hotmail.com; asen@mix.wvu.edu

Sex: Male $\underline{\text { Age: }} 26$ Citizenship: India

\section{Educational Qualifications:}

- MS in Biochemistry with specialization in Reproductive Biology, Calcutta University, India 2000-2002.

- BS in Microbiology (major) with Chemistry and Zoology (minor), Bangalore University, India 1997-2000.

\section{Peer Reviewed Publications:}

1. Expression and Activation of PKC isozymes by Prostaglandin F $2 \alpha$ in the early and mid luteal phase bovine corpus luteum. Aritro Sen, J Browning, E K Inskeep, P Lewis, J A Flores. Biology of Reproduction 70,379-384 (2004).

2. Developmental sensitivity of the bovine corpus luteum (CL) to prostaglandin $\mathrm{F}_{2 \alpha}\left(\mathrm{PGF}_{2 \alpha}\right)$ and endothelin-1: Is ET-1 a mediator of the luteolytic actions of $\mathrm{PGF}_{2 \alpha}$ or a tonic inhibitor of progesterone secretion? Ekta Choudhary, Aritro Sen, E Keith Inskeep and Jorge A Flores. Biology of Reproduction 72, 633-642 (2005).

3. Effects of selective protein kinase $\mathrm{C}(\mathrm{PKC})$ isoforms in $\mathrm{PGF}_{2 \alpha}$-induced $\mathrm{Ca}^{2+}$ signaling and $\mathrm{LH}$ induced progesterone (P4) accumulation in the mid-phase bovine corpus luteum (CL). Aritro Sen, Ekta Choudhary, E. 
Keith Inskeep, Jorge A Flores. Biology of Reproduction 72,976-984 (2005).

4. Cellular Source of Luteal PKC Isozymes and their Activation by Endothelin-1 (ET-1) in the Mid-Phase Bovine Corpus Luteum (CL). Aritro Sen, Marietta Wright, E. Keith Inskeep and Jorge A. Flores. (submitted for publication)

\section{Abstracts in Refereed Journals:}

1. Sensitivity of the day 4 and day 10 bovine corpus luteum to Endothelin-I. JA Flores, E Choudhary, A Sen, E K Inskeep. Biol. Reprod 2004 Special Issue (Abstract Book): Abs. no. 786. Poster presented in the $37^{\text {th }}$ Annual meeting of SSR, Vancouver, British Columbia, Canada 2004.

2. Cellular Source of Luteal PKC Isozymes and their Activation by Endothelin-1 (ET-1) in the Mid-Phase Bovine Corpus Luteum (CL). Aritro Sen, E. Keith Inskeep and Jorge A. Flores. Poster (M784), $38^{\text {th }}$ Annual meeting of SSR, Quebec City, Quebec, Canada 2005.

\section{Posters and Oral Presentations:}

1. Protein Kinase C: Expression in the early and mid luteal phase of bovine corpus luteum. Aritro Sen, J Browning, E K Inskeep, P Lewis, J A Flores. Research Horizons Poster Session, Eberly College of Arts and Sciences, WVU, April 22, 2003, Poster.

2. Intra-cellular mechanisms of bovine luteal sensitivity to prostaglandin F2alpha $\left(\mathrm{PGF}_{2 \alpha}\right)$. Aritro Sen*, Joseph Browning, Ekta Choudhary, E. Keith Inskeep, Paul Lewis, Jorge A. Flores. Graduate Students Research Conference Papers, Davis College of Agriculture, Forestry and Consumer Sciences, WVU 2004, Oral presentation.

3. Sensitivity of luteal steroidogenic and endothelial cell populations to endothelin-1 and prostaglandin F2 alpha. Ekta Choudhary*, Aritro Sen, E. Keith Inskeep, Jorge A. Flores. Graduate Students Research Conference Papers, Davis College of Agriculture, Forestry and Consumer Sciences, WVU 2004, Oral presentation. 
4. Cellular Source of Luteal PKC Isozymes and their Activation by Endothelin-1 (ET-1) in the Mid-Phase Bovine Corpus Luteum (CL). Aritro Sen, E. Keith Inskeep and Jorge A. Flores. West Virginia Academy of Sciences (WVAS) Conference, WVU, April 23 2005, Oral presentation.

5. Cellular Source of Luteal PKC Isozymes and their Activation by Endothelin-1 (ET-1) in the Mid-Phase Bovine Corpus Luteum (CL). Aritro Sen, E. Keith Inskeep and Jorge A. Flores. Sigma XI Graduate Research Conference, WVU, April 25 2005, Poster.

\section{Professional Affiliation:}

Trainee member of Society for the Study of Reproduction (SSR). Served in the Minority Affairs Committee, 2005-2006.

West Virginia Academy of Sciences (WVAS)

\section{Teaching Experience:}

Courses taught:

Undergraduate Bio 115 laboratory, Basic biology.

Undergraduate Bio 117 laboratory, The Functional Diversity of Organisms.

Undergraduate Bio 219 laboratory, Basic Molecular Biology Techniques.

Undergraduate Bio 441 lecture \& laboratory, Vertebrate Micro-anatomy.

\section{Honors:}

1. HERF Fellowship, West Virginia University.

2. Eberly College of Arts and Sciences Graduate Travel Assistance Award, 2005-06.

3. West Virginia University Graduate Student Travel Award, 2005-06.

4. SSR-Larry Ewing Memorial Trainee Travel Award, 2005. 